\title{
Geochemical Baseline Studies and Relations Between Water Quality and Streamflow in the Upper Blackfoot Watershed, Montana: Data for July 1997 - December 1998
}

By Sonia A. Nagorski, ${ }^{1,2}$ Johnnie N. Moore, ${ }^{1}$ and David B. Smith ${ }^{2}$

${ }^{1}$ Murdock Environmental Biogeochemistry Laboratory,

Department of Geology, University of Montana, Missoula, MT 59812

${ }^{2}$ U.S. Geological Survey, Denver Federal Center, MS 973, Denver, CO 80225

U.S. Geological Survey Open File Report 01-0059 


\title{
G eochemical B aseline Studies and R elations B etween $\mathbf{W}$ ater $\mathbf{Q}$ uality and Streamflow in the Upper Blackfoot Watershed, M ontana: Data for J uly 1997- December, 1998.
}

Authors: Sonia A. Nagorski ${ }^{1,2}$, Johnnie N. Moore1, and David B. Smith ${ }^{2}$

${ }^{1}$ Murdock Environmental Biogeochemistry Laboratory, Department of Geology, University of Montana, Missoula, MT 59812

2U.S. Geological Survey, Denver Federal Center, MS 973, Denver, CO 80225

\begin{abstract}
We used ultraclean sampling techniques to study the solute (operationally defined as $<0.2 \mu \mathrm{m}$ ) surface water geochemistry at five sites along the Upper Blackfoot River and four sites along the Landers Fork, some in more detail and more regularly than others. We collected samples also from Hogum Creek, a tributary to the Blackfoot, from Copper Creek, a tributary to the Landers Fork, and from ground water seeps contributing to the flow along the Landers Fork. To better define the physical dynamics of the hydrologic system and to determine geochemical loads, we measured streamflow at all the sites where we took samples for water quality analysis. The Upper Blackfoot River, which drains historic mines ca. $20 \mathrm{Km}$ upstream of the study area, had higher trace metal concentrations than did the Landers Fork, which drains the pristine Scapegoat Wilderness area. In both rivers, many of the major elements were inversely related to streamflow, and at some sites, several show a hysteresis effect in which the concentrations were lower on the rising limb of the hydrograph than on the falling limb. However, many of the trace elements followed far more irregular trends, especially in the Blackfoot River. Elements such as $\mathrm{As}, \mathrm{Cu}, \mathrm{Fe}$, $\mathrm{Mn}, \mathrm{S}$, and $\mathrm{Zn}$ exhibited complex and variable temporal patterns, which included almost no response to streamflow differences, increased concentrations following a summer storm and at the start of snowmelt in the spring, and/or increased concentrations throughout the course of spring runoff. In summary, complex interactions between the timing and magnitude of streamflow with physical and chemical processes within the watershed appeared to greatly influence the geochemistry at the sites, and streamflow values alone were not good predictors of solute concentrations in the rivers.
\end{abstract}




\section{Table of C ontents}

Introduction

Methods

1. Sampling locations and frequencies 1

2. Streamflow measurement 2

3. Water sampling 2

4. Lab Methods 3

5. Quality Assurance/ Quality Control 4

$\underline{\text { Results and Discussion }} \quad 5$

1. Streamflow 5

a) Streamflow at Landers Fork (sites LA, LB, LC, LD) and Copper Creek (site C) 5

b) Streamflow at Blackfoot River (sites BH, BB, BC, and BD) and Hogum Creek (site HC) 6

2. Surface Water Geochemistry $\quad 7$

a) Landers Fork and Copper Creek 8

1) Copper Creek $\quad 8$

2) Landers Fork at LA 9

3) Landers Fork at LB 9

4) Landers Fork at LC 10

5) Landers Fork at LD 11

b) Blackfoot River and Hogum Creek 11

1) Blackfoot River at $\mathrm{BH}$

2) Hogum Creek 12

3) Blackfoot River at BB 12

4) Blackfoot River at BC 13 
Summary

$\underline{\text { References }}$

Tables:

$\begin{array}{ll}\text { 1. Discharge measurements } & 18\end{array}$

2. $\mathrm{pH}$ meter and D.O. meter calibrations 20

3. Sample analysis dates 20

4. Detection limits of analytes 20

5. External and internal standards 21

6. Summary of USGS standards measured on ICAPES 22

7. Duplicates and spike recoveries 23

8. Laboratory and field blanks $\quad 24$

9. All data for water samples collected April 1998-December 199825

Figures:

1. Site location map 31

2. Streamflow vs. concentrations at Copper Creek 32

3. Trends over time at Copper Creek 34

4. Loads at Copper Creek $\quad 37$

5. Streamflow vs. concentrations at Landers Fork site LA 39

6. Trends over time at Landers Fork site LA 41

7. Loads at Landers Fork site LA 44

8. Streamflow vs. concentrations at Landers Fork site LB 46

9. Trends over time at Landers Fork site LB 48

10. Loads at Landers Fork site LB 51

11. Streamflow vs. concentrations at Landers Fork site LC 53

12. Trends over time at Landers Fork site LC 55

13. Loads at Landers Fork site LC 58 
14. Streamflow vs. concentrations at Landers Fork site LD

15. Trends over time at Landers Fork site LD 62

16. Loads at Landers Fork site LD 65

17. Streamflow vs. concentrations at Blackfoot River site BH 67

18. Trends over time at Blackfoot River site BH 69

19. Loads at Blackfoot River site BH 72

20. Streamflow vs. concentrations at Hogum Creek 74

21. Trends over time at Hogum Creek 76

22. Loads at Hogum Creek 79

23. Streamflow vs. concentrations at Blackfoot River site BB 81

24. Trends over time at Blackfoot River site BB 83

25. Loads at Blackfoot River site BB 86

26. Streamflow vs. concentrations at Blackfoot River site BC 88

27. Trends over time at Blackfoot River site BC 90

28. Loads at Blackfoot River site BC 93 


\section{Introduction}

This report presents the results of a temporal and spatial investigation of the surface water geochemistry of the upper Blackfoot River and Landers Fork in western Montana. These two rivers come together at the site of a proposed large-scale open-pit gold mine, and it is for this reason that they were chosen for study by the Mineral Resources Program (MRP) of the U.S. Geological Survey (USGS). The characterization of water quality in mineralized basins, whether impacted by mining or not, has potentially strong regulatory implications. Only recently have researchers begun to examine detailed spatial and temporal trends in watersheds using clean sampling techniques, which have been shown to be critical in obtaining accurate dissolved trace metal data (Windom et al., 1991; Benoit, 1994; Taylor and Shiller, 1995)

The Blackfoot River watershed is located in west-central Montana, where if flows for $215 \mathrm{~km}$ before joining the Clark Fork, a major tributary to the Columbia River. Several historic mines, which have been linked to water and bed sediment contamination in the watershed, are located in the headwaters of the Blackfoot River, 20-30 Km upstream of this project's study area (Moore et al., 1991; Menges, 1997; Nagorski et al., 2000). In contrast, the Landers Fork largely drains a pristine area, a section of the rugged Scapegoat Wilderness area. The upper Blackfoot River and the Landers Fork flow adjacent to the undeveloped McDonald Gold Project area before joining together to the southwest of the ore deposit (Figure 1).

The first portion of this project is detailed in Nagorski et al. (1998) which describes the results of data collected from July, 1997 until March, 1998. Here we focus on data collected between April and December, 1998. Although many sections of this report include the July 1997- March 1998 data, the reader is referred to the 1998 OFR for details on the first portion of the project. In addition, Nagorski et al. (2000) place the study area in geochemical context to the rest of the Blackfoot basin by reporting on a one-time, basinscale sampling event of the water and bed sediment of the Blackfoot River and its major tributaries.

\section{M ethods}

\section{Sampling locations and frequencies:}

The sites sampled between April and December, 1998 were the same as those visited between July, 1997 and March, 1998, the time period that was the focus of the earlier report (Nagorski et al., 1998) (Figure 1). Between April and August, 1998, we sampled at four sites along the Landers Fork (LA, LB, LC, and LD), three sites along the Blackfoot River (BH, BB, and BC), one site at Copper Creek (C) and one at Hogum Creek (HC) four to six times per site. We continued sampling at two of the Landers Fork sites (LB and LC) and two of the Blackfoot River sites (BB and BC) approximately monthly through December, 1998 (although sites LB and BC could not be accessed in December, 1998). One site reported in the 1998 OFR (site BA) was not sampled later than September, 1998 and therefore is not included in this report. Site BD, below the confluence of the Landers Fork and Blackfoot River was sampled from July to September, 1997, and then only in August, 1998.

During the study period, we collected samples of seep water emerging from the streambanks at sites LB and LC when possible-- in April at LB, and in April, October, November, and December at site LC. During the other times, the seeps were submerged by channel flow. 


\section{Streamflow measurement:}

We measured streamflow at each sampling site using a Price AA current meter connected to an Aqua Calc 5000 calculator (Rickly Hydrological Co.). We made the measurements by wading across transects at each sampling site, although two high flow events at site LC necessitated the use of a bridge crane from which we suspended the current meter.

Between 5 and 29 velocity measurement stations were used along each streamflow transect. Those channels where flow was measured using fewer than 10 stations were mostly less than $5 \mathrm{~m}$ in width. We spaced the stations so as to account for obvious changes in depth and velocity, and we attempted to set up each station to represent approximately equal flow sections of the channel. At each station, we set the current meter at $60 \%$ of the water depth. Because no station was deeper than 1 meter, it was not necessary to make a more detailed vertical profile.

During the majority of the sampling events, we measured streamflow twice at each site in order to define the measurement precision. We set up each replicate measurement along a separate transect, usually within $3 \mathrm{~m}$ of the original. Replicate measurements at sites with less than $5 \mathrm{ft}^{3} / \mathrm{s}(142 \mathrm{~L} / \mathrm{s})$ of flow were within 14\%; at sites with streamflow between 5 and $35 \mathrm{ft}^{3} / \mathrm{s}(142-991 \mathrm{~L} / \mathrm{s})$, reproducibility was within $9 \%$, and at sites where flows were greater than $35 \mathrm{ft}^{3} / \mathrm{s}(991 \mathrm{~L} / \mathrm{s})$, the precision was better than $7 \%$. At sites where we took only one streamflow measurement, the error given to the measurement is assumed to be the maximum precision error found in the appropriate streamflow bracket.

We report the streamflow measurements (as well as the mean velocity, number of stations, and channel width at each transect) in Table 1, with the English units (cubic feet per second) used by the Aquacalc. However, in subsequent figures and in the load calculations, the measurements are converted into metric units.

\section{Water sampling}

Two people were present for each sampling event. While one person measured streamflow, the other took measurements of $\mathrm{pH}$, dissolved oxygen, conductivity, air temperature, and water temperature. We used an Orion model 230A pH meter, an Orion model 820 dissolved oxygen meter, a Hach Conductivity/TDS meter, and a Barnant 100 Thermocouple Thermometer for these purposes. The $\mathrm{pH}$ and dissolved oxygen meter were calibrated at least once a day, and their calibrations were checked and redone if necessary at each new sampling site (Table 2).

We followed the clean sampling techniques as generally recommended by Windom et al.(1991), Benoit (1994), and Taylor and Shiller (1995) in order to minimize the chances of contaminating the samples. We stored each sample bottle in double zip-close bags, from which we removed it only moments before sampling. The sampler contacted the bottles wearing new and clean latex or nitrile gloves. With the help of the other person, the sampler wearing the clean gloves contacted nothing but the sample bottle and the inner storage bag.

Generally, we took three 1-L samples per site. An exception to this was made in August, 1998, when we collected 10 samples from site LD in order to see if any more variability within a transect would be captured by taking more than the standard three samples. After rinsing the sample bottle with one volume of stream water, the sampler 
filled each bottle by depth integrating in the area upstream of where the sampler stood. We obtained the samples upstream of the area where we had disturbed the site by measuring streamflow and the other in situ parameters. In addition, we always took samples upstream of bridges in order to limit additional sources of contamination. The sample bottles were immediately returned to their zipped double bags and stored on ice until return to the laboratory.

All collection materials (bottles, syringes, etc.) that could potentially ever come into contact with the water sample were extensively pre-cleaned. The cleaning procedure consisted of a regular wash with warm water and soap, several rinses in deionized water, soaking in $6 \mathrm{~N} \mathrm{HCl}$ for 2 hours, three rinses in Milli-Q deionized water, soaking in a $1 \%$ (by volume) trace-metal grade $\mathrm{HNO}_{3}$ bath for 24 hours, another three rinses in Milli-Q, and drying and storing into clean plastic bags under a Class 100 laminar flow hood.

\section{Lab Methods}

The laboratory methods for sample treatment and analysis did not differ for the samples collected in this second half of the project as reported for the first in Nagorski et al.(1998). Although the reader is again referred to the previous report for details, a summary of the methods is presented here.

We filtered samples upon return to the laboratory within 30 hours following collection. We kept the samples on ice until filtering, when we removed them from their double bags under a Class 100 Laminar Flow Hood at the University of Montana Murdock Environmental Biogeochemistry Laboratory. Again, we wore clean nitrile or latex gloves whenever handling the sample bottles and any other sample storage or processing materials (syringes, filters, etc.) We filtered the samples through $0.2 \mu \mathrm{m}$ syringe filters with glass prefilters (Gelman Sciences Serum Acrodiscs). We used at least $50 \mathrm{~mL}$ of sample to rinse the syringe, filter, and bottle and to reduce the effective pore size (and as a result, the passage of colloidal material) of the filters (Taylor and Shiller, 1995). Following the purging by the $50 \mathrm{~mL}$ of sample, we filled a $60 \mathrm{~mL}$ amber glass bottle with filtered sample for the purposes of carbon and anion analysis. Finally, we filled a $125 \mathrm{~mL}$ plastic bottle with filtered sample material for cation and arsenic analysis. We stored the amber bottles in a 4 degrees Celcius refrigerator while awaiting carbon/anion analysis, whereas we acidified the samples in the plastic bottles to $\mathrm{pH}<2$ with ultrapure, double distilled from quartz Optima (FisherScientific) HCl.

We measured trace element and major cation concentrations in the water samples using a Thermo Jarrel-Ash ICP (IRIS) with ultrasonic nebulization (Cetac, U-5000AT+) according to EPA Method 200.15 (Martin et al., 1994). This method was modified slightly in that we did not add nitric acid nor hydrogen peroxide to the samples. Nitric acid was previously determined by the laboratory to not improve analytical performance, and hydrogen peroxide was not necessary because arsenic was not being analyzed on the ICP.

We analyzed for dissolved anions by ion chromatography according to EPA Method 300.0 (Pfaff, 1993) within 48 hours of collection, although this analysis was done only for the July, 1997 through January, 1998, August, 1998 and October, 1998 samples. We did not analyze for anions in all samples because most anions consistently were below the detection limit and sulfate information could be inferred from the sulfur analysis done on the ICP.

We measured dissolved inorganic carbon with a Shimadzu Carbon analyzer within one week of sample collection according to Standard Method 505A (Franson, 1985a). Due 
to technical problems with the Shimadzu Carbon analyzer in the summer and fall of 1998, we did not analyze inorganic carbon on all samples collected in that time period. However, we measured total alkalinity by titration with sulfuric acid on any samples that did not receive analysis for inorganic carbon, and both total alkalinity and dissolved inorganic carbon were measured on many of the fall, 1998 samples. As reported in Nagorski et al. (1998), the Shimadzu Carbon analyzer was also used to measure organic carbon according to Franson (1985). However, poor performance by the instrument during large portions of the rest of the study period precludes us from reporting organic carbon values.

Arsenic analysis was done using atomic absorption spectroscopy with hydride generation (HGAAS) according to Standard Method 303A (Franson, 1985b). This method was modified by the Murdock Environmental Biogeochemistry Laboratory to optimize analytical performance (Mickey, written communication, 1997). The modifications consisted of adding $\mathrm{KI}$ and $\mathrm{HCl}$ to the samples and standards to achieve final concentrations of $2 \% \mathrm{KI}$ and $1 \mathrm{M} \mathrm{HCl}$ and of running solutions of $0.35 \% \mathrm{NaBH}_{4}$ (stabilized with $0.5 \% \mathrm{NaOH}$ ) and $6 \mathrm{~N} \mathrm{HCl}$ through the hydride generation during analysis.

Table 3 lists the dates on which analysis was performed on the various instruments for each set of samples.

\section{Quality Assurance/ Quality Control}

We conducted sample analysis at the Murdock Environmental Biogeochemistry Laboratory according to a strict quality assurance/ quality control program. Instrument calibrations were designed to linearly bracket the concentrations of analytes in the water samples. Each instrument used for sample analysis was calibrated at the start of each day and checked for accuracy and precision following the analysis of every 10 samples. Accuracy was measured through the analysis of laboratory fortified blanks (internal standards), external standards, laboratory fortified samples (spikes), and laboratory reagent blanks. Precision was evaluated by running replicate samples and standards during single and over multiple analytical events. The practical quantification limit (PQL) was determined as the threshold at which a sample can be reproduced within a maximum variability of $30 \%$ (Table 4). It should be noted that the PQLs for $\mathrm{Cu}$ and $\mathrm{Zn}$ have been modified since Nagorski et al. (1998). The PQL for $\mathrm{Cu}$ has been determined to be 0.8 $\mu \mathrm{g} / \mathrm{L}$ instead of the previously reported $0.3 \mu \mathrm{g} / \mathrm{L}$, and $\mathrm{Zn}$ has been set at $0.3 \mu \mathrm{g} / \mathrm{L}$ instead of $0.2 \mu \mathrm{g} / \mathrm{L}$.

The following summary of the quality control results includes all analyses of samples collected for the project (from July, 1997 through December, 1998).

External standards: Six different external standards were analyzed on the HGAAS with the arsenic samples, and each measured within the reported acceptable range (Table 5.1). The external sample "QC Spex" analyzed on the Ion Chromatograph also fell within the reported range (Table 5.2). On the ICP, three USGS standards (USGS T-107, USGS T-143, and USGS T-145) were run with sample analyses, and the average measured concentrations of most elements fell within the reported acceptable range (Tables 6.1-6.3). Those elements whose average readbacks did not fall within the reported range were Sr, which measured low on all three standards, and Ag, which measured high on USGS T143. 
Internal standards: The mean percent difference between known and measured values of internal standards measured on the HGAAS, Carbon analyzer, and Ion Chromatograph was less than $7.1 \%$ (Table 5.3).

Duplicates: The mean percent difference of sample duplicates run on all instruments was less than $8 \%$ (Tables 7.1 and 7.2).

Spikes: Mean percent spike recoveries for all measurable elements were between 86 and $112 \%$ (Tables 7.3 and 7.4).

Blanks: Laboratory reagent blanks were all below the PQL on all instruments (Tables 8.1 and 8.3). Field collected blanks, which check for contamination rather than analytical quality control, were mostly below the PQL for all elements as well (Tables 8.2 and 8.4). Exceptions are for $\mathrm{Ca}, \mathrm{Mg}, \mathrm{Na}, \mathrm{S}, \mathrm{Si}$, and $\mathrm{Zn}$, which were detectable in 2 to 23 of the 31 field blanks. The concentrations of $\mathrm{Ca}, \mathrm{Mg}, \mathrm{S}$, and $\mathrm{Si}$ found in the blanks were inconsequential, as they were at least an order of magnitude lower than concentrations found in environmental samples. However, the highest Na concentration $(0.42 \mathrm{mg} / \mathrm{L})$ detected in the field blanks could explain the noisiness of much of the $\mathrm{Na}$ data. The appearance of $3.7 \mu \mathrm{g} / \mathrm{L}$ of $\mathrm{Zn}$ in one of the field blanks unfortunately calls into question much of the $\mathrm{Zn}$ data. However, it should be noted that 24 of the 31 field blanks did not have quantifiable $\mathrm{Zn}(<0.3 \mu \mathrm{g} / \mathrm{L})$, and the vast majority of samples from the Landers Fork did not have detectable $\mathrm{Zn}$ either. The value of the highest $\mathrm{Zn}$ in the blanks $(3.7 \mu \mathrm{g} / \mathrm{L})$ found is included in the plots of $\mathrm{Zn}$ concentrations.

\section{Results and Discussion}

\section{Streamflow}

As described in the Nagorski et al. (1998) streamflow at most of the sites decreased over the time period of the first half of the study, between July, 1997 and March, 1998. Between April and December, 1998, we found a more variable streamflow pattern, as would be expected due to the occurrence of spring runoff during this time period. At most sites we streamflow started to rise in April, with runoff lasting through the month of July.

\section{a) Streamflow at Landers F ork (sites LA, LB, LC, LD) and Copper Creek (site C):}

Streamflow patterns at C and LA were similar on the dates they were measured in 1998, in that the highest flows measured were in mid May and early June (Table 1 and Figures $3 a$ and $6 a$ ). Although site LA had no streamflow on 4/7/98, we measured 878-935 $\mathrm{L} / \mathrm{s}$ at the site less than three weeks later (on 4/26/98), and $4220 \mathrm{~L} / \mathrm{s}$ in mid-May. We reported a similarly rapid increase in streamflow at site C, with streamflow at 396-425 L/s in early April to 2917-3002 L/s in mid-May. In late July (7/20/98), streamflow at both sites was between 1699 to $1813 \mathrm{~L} / \mathrm{s}$, still well above the low flow levels observed the previous fall and winter.

On five occasions between April and December, 1998, sites C, LA, and LB were all measured on the same day, allowing for an evaluation of whether the reach above LB was gaining, losing, or averaging at a constant flow level. Results of this evaluation show that on $4 / 7 / 98,4 / 26 / 98$, and $5 / 18 / 98$, the reach was losing flow to the ground water 
system. However, there was no measurable difference in the combined streamflow of $\mathrm{C}$ and LA and that at LB on 6/5/98 and 7/20/98.

At site LB, the highest flow measured over the study period was on $6 / 29 / 98$, with 11,696 to $11,894 \mathrm{~L} / \mathrm{s}$. This is a drastic increase over the 28 to $340 \mathrm{~L} / \mathrm{s}$ measured during all 5 events between November, 1997 and late April, 1998. Site LB was never observed to be frozen, even in the cold winter months. An explanation for this was found on 4/7/98, when we walked approximately $200 \mathrm{~m}$ upstream of the sampling site, and found where the surface flow was originating. An ice-free pool about 8-10 meters in diameter and up to approximately $1 \mathrm{~m}$ deep was observed on both 4/7/98 and 4/26/98, and a school of 10-20 $\mathrm{cm}$ long fish were seen inhabiting the pool. Downgradient of the pool, streamflow gradually increased, and more seeps were visible along the stream channel. The seeps downstream of the pool were those that were sampled on both 4/7/98 and 4/26/98, and are listed as "LB Seeps" in Table 9.

At site LC, the streamflow pattern was consistent with that reported in the first portion of the study, which is that streamflow at LC was higher that at LB on every sampling event. Because of this as well as the observance of complete absence of ice at the site during the 18 month study period, we conclude that ground water input is critical in maintaining streamflow at the site during low flow and winter conditions. Other studies in the area have attributed the gaining system to a structural bedrock feature in the area which constricts the local alluvium (Schafer and Associates, 1994). Again, as reported in Nagorski et al. (1998), numerous seeps were visible along the east bank of the river at LC, and when not submerged by channel flow, samples were taken from these areas and are reported as "LC Seeps" in Table 9.

Between April and December 1998, we measured site LD only three times (on 4/7/98, 7/20/98, and 8/17/98). On both occasions (on 4/7/98, 7/20/98) that both LC and LD were measured, the reach between the sites was losing streamflow .

b) Streamflow at Blackfoot River (sites BH, BB, BC, and BD) and Hogum Creek (site $\mathrm{HC})$ :

Surface water at the most upstream site $(\mathrm{BH})$ on the Blackfoot River was not found to be frozen at any time when it was visited between July, 1997 and August ,1998.

Streamflow was never measured as lower than $566 \mathrm{~L} / \mathrm{s}$, while the highest flow was 2917 $3144 \mathrm{~L} / \mathrm{s}$ during the study period. The streamflows measured in 1998 did not exceed the high flow measured at the site on 7/4/97. However, we did not visit site BH on 6/29/98, which is when we measured the highest streamflows of the entire study period at sites BB and $\mathrm{BC}$ downstream.

Hogum Creek's (HC) highest flow was measured on 6/5/98, with 396-425 L/s. The last time it was sampled, on 8/17/98, the flow level $(57-85 \mathrm{~L} / \mathrm{s})$ was already close to that measured in November, 1997 and January, 1998 (28 L/s).

There were four events between April and August 1998 when sites BH, HC, and $\mathrm{BB}$ were all measured, allowing for an evaluation of gaining versus losing status of the stretch of river above site BB. The stretch is calculated to have been losing on 4/29/98, $6 / 5 / 98$, and 7/20/98, but there was no measurable net gain nor loss on 5/19/98.

Between April and December, 1998, both BB and BC were measured and sampled 9 times. Results indicate that there was no measurable net gain or loss of streamflow along the reach between these two sites on 4/7/98, 5/19/98, 7/20/98, and 10/6/98. However, 
streamflow at BC was higher than at BB on 4/29/98, 6/5/98, 6/29/98, 9/4/98, and 11/7/98. As reported in the 1998 OFR, the reach was gaining streamflow on 5 of the 6 measurement events between July 1997 and March, 1998. Overall, it appears that this stretch of river is not losing, and it is more often than not a gaining reach. The important role of ground water input along the reach is also implied by the observation that site $\mathrm{BC}$ was also never found to be frozen (unlike site BB); and flow did not drop below $396 \mathrm{~L} / \mathrm{s}$ at any time that we studied the site.

As mentioned earlier, site BD, below the confluence of the Landers Fork and Blackfoot River, was sampled only once after September, 1997. On 8/17/98, streamflow at the site $(3087 \mathrm{~L} / \mathrm{s})$ was similar to measurements made in the late summer of 1997 (4276 $\mathrm{L} / \mathrm{s}$ in 8/7/97 and $2266 \mathrm{~L} / \mathrm{s}$ in 9/14/97.)

\section{Surface $\mathbf{W}$ ater $\mathbf{G}$ eochemistry}

The surface water solute chemistry of the Landers Fork was generally different from that of the Blackfoot River. Overall comparisons of dissolved concentrations show the Blackfoot samples had higher concentrations of organic carbon, sulfate, $\mathrm{Cu}, \mathrm{Fe}, \mathrm{K}$, $\mathrm{Mn}, \mathrm{Na}, \mathrm{S}, \mathrm{Si}, \mathrm{Sr}$, and $\mathrm{Zn}$ and lower concentrations of inorganic carbon, As, and $\mathrm{Ca}$ than the Landers Fork, (based on t-tests with p-values $<0.05$ ) during the study period. The rivers had similar $\mathrm{pH}$ values, water temperatures, and dissolved oxygen, $\mathrm{Ba}, \mathrm{Li}$, and $\mathrm{Mg}$ concentrations. No samples had detectable concentrations of $\mathrm{Ag}(<1 \mu \mathrm{g} / \mathrm{L}), \mathrm{Be}(<0.05$ $\mu \mathrm{g} / \mathrm{L}), \mathrm{Cd}(<0.5 \mu \mathrm{g} / \mathrm{L}), \mathrm{Co}(<0.5 \mu \mathrm{g} / \mathrm{L}), \mathrm{Mo}(<1 \mu \mathrm{g} / \mathrm{L}), \mathrm{Ni}(<2 \mu \mathrm{g} / \mathrm{L}), \mathrm{Pb}(<6 \mu \mathrm{g} / \mathrm{L}), \mathrm{Ti}$ $(<2 \mu \mathrm{g} / \mathrm{L})$, and $\mathrm{V}(<2 \mu \mathrm{g} / \mathrm{L})$.

Concentrations of most solutes were inversely related to streamflow in both the Landers Fork and the Blackfoot River sites through the summer and fall of 1997. However, in the 11/97, 1/98, and 3/98 samples, most solutes differed from this trend, as concentrations dropped while streamflow continued to decrease. Following the start of spring runoff in April, 1998, most of the major ions decreased in concentration through the rising limb of the runoff hydrograph, and subsequently rose throughout the rest of study period through summer and fall. Few generalizations can be made about the behavior of the trace elements in the Blackfoot River, although several increased in concentration during high flow events. On most events, the trace metal concentrations were below detection in the Landers Fork, indicating that more sensitive analysis (e.g. by ICP-Mass Spectrometer) is necessary to detect any ultra-low levels at this site. This result further justifies the use of clean sampling and handling techniques. Furthermore, the authors recognize that the operationally defined dissolved phase $(<0.2 \mu \mathrm{m})$ sampled in this project may in fact not reflect the truly dissolved phase because of the possibility that colloids passed through the filters. During high flow events, suspended solid concentrations are typically elevated in rivers, and hence the chances of obtaining suspended particles in the filtrate may have increased as well.

Hysteresis patterns were observed for some elements at most of the study sites, indicating that factors other than the amount of streamflow need to be considered when predicting the solute geochemistry in the rivers. Hysteresis describes a loop pattern in plots of concentration vs. discharge caused by elemental concentrations differing along the falling limb from the rising limb of a hydrograph. Hysteresis patterns have been reported by many authors studying storm-scale and seasonal hydrographs in a wide variety of streams and rivers (e.g. Bird, 1987; Hooper et al., 1990; Droppo and Jaskot, 1995; Bhangu and Whitfield, 1997, Evans and Davies, 1998). The direction of hysteresis rotation can be clockwise or counterclockwise, and it is thought to signify which geochemically distinct sources in the watershed are dominating streamflow at different times. In clockwise hysteresis, elemental concentrations are higher during the rising limb of the 
hydrograph than along the falling limb. That is, water sources with higher solute concentrations are larger contributors to streamflow during early spring runoff than later in the year (considering a seasonal hydrograph). Counter-clockwise rotation indicates the opposite - that solutes are more dilute on the rising limb than on the falling limb. Seasonal counter-clockwise rotation would be expected in watersheds which contain snowpacks. When thawed in the spring, the snowpack would presumably produce overland surface flow of snowmelt, thereby dominating contributions to the stream channel and creating more dilute geochemical conditions (Bhangu and Whitfield, 1997). In other words, counter-clockwise hysteresis may be an indication of ground water and soil water (presumably dominant during late summer and fall) having higher elemental concentrations or longer residence times in the soils than the spring runoff water, or "surface event water", as defined by Evans and Davies (1998). The differences in the widths of the loops are likely an indication of greater or lesser chemical differences among the various water sources supplying streamflow during different periods in the hydrocycle (Johnson and East, 1982).

Site-specific geochemical trends are described below.

\section{a) Landers F ork and Copper Creek}

\section{1) Copper Creek:}

As can be seen on Figure 2, a hysteresis effect is present for inorganic carbon, Ba, $\mathrm{Ca}, \mathrm{Li}, \mathrm{Mg}$, and $\mathrm{Sr}$. The effect is counter-clockwise in that the concentrations of these elements are higher on the falling limb of the hydrograph (Summer--Fall-Winter 1997, and late Summer 1998) than on the rising limb of the hydrograph (Spring 1998). The cyclical patterns of these elements have an overall negative relationship $(r<-0.85$, $p$-value $<0.01)$ with streamflow, meaning that elemental concentrations are higher with lower streamflow on each of the falling and rising limbs. Of the above mentioned elements, $\mathrm{Ba}, \mathrm{Ca}, \mathrm{Mg}$, and Sr show a wider hysteresis loop, while inorganic carbon, $\mathrm{K}$, and Li have much tighter loops.

Despite its name, Copper Creek did not have detectable $(>0.8 \mu \mathrm{g} / \mathrm{L})$ concentrations of filterable $\mathrm{Cu}$ (Figure 3h). Chromium was less than its PQL of $1 \mu \mathrm{g} / \mathrm{L}$ at all times except for January, 1998, when it was detected at levels near the quantifiable limit (Figure 3g). Iron was found in the 1997 samples only, when streamflow was in falling limb and baseflow conditions (Figure 3i). During spring runoff in 1998, Fe was not detected. Similarly, Mn was detected at or above above the PQL of $0.3 \mu \mathrm{g} / \mathrm{L}$ only during the first four sampling events, July to September, 1997 (Figure 3m). Zinc was mostly below the $\mathrm{PQL}$ as well, and it was always below the concentration found in the highest field blank (Figure 3r).

Arsenic did not correlate well with streamflow, although its slope was positive overall ( $\mathrm{r}=0.68, \mathrm{p}=0.03$ ) (Figure 2c). Its concentration in Copper Creek stayed relatively constant over the course of the 13 month study, with the exception of a slight increase in As concentrations during the two highest streamflows measured, in July, 1997 (Figure $3 \mathrm{~d})$. Another anomaly in the dataset is $\mathrm{S}$, which despite having a negative relationship with streamflow $(r=-0.79, p=0.007)$ did not have a clear hysteresis loop (Figure 21). In addition, $\mathrm{S}$ concentrations were higher during runoff in 1998 than during the falling limb of the 1997 streamflow, an opposite trend to those seen for the major elements. Finally, $\mathrm{pH}$ at the site exhibited counter-clockwise hysteresis, with $\mathrm{pH}$ lower $(\mathrm{pH}=8.0)$ at spring runoff compared to the previous fall and winter $(\mathrm{pH}=8.1-8.4)$ and to the post-runoff sample in July 1998 (pH=8.4) (Figure 2a). 
Elemental loads in Copper Creek (calculated as streamflow multiplied by concentration) generally follow a pattern identical to streamflow (Figure 3a and 4). Hence, the amount of streamflow is the dominant factor in influencing the loading of dissolved elements in Copper Creek, and any variations in dissolved concentrations are largely insignificant.

\section{2) Landers Fork at LA}

Overall, a similar hysteresis effect is seen at site LA as at site C. Inorganic carbon, $\mathrm{Ba}, \mathrm{Ca}, \mathrm{K}, \mathrm{Li}, \mathrm{Mg}$, Si, and $\mathrm{Sr}$ all have counter-clockwise hysteresis loops (Figures 5b, d, $\mathrm{e}, \mathrm{g}, \mathrm{h}, \mathrm{i}, \mathrm{m}$, and $\mathrm{n})$. Only Ba, K, and Sr had significantly $(\mathrm{p}<0.04)$ negative $(\mathrm{r}<-0.74)$ relationships with streamflow. However, it should be noted that at this site there are far more falling limb datapoints than rising limb points, and fewer data points overall due to the lack of streamflow at the sites during many winter months.

Trace element relationships to streamflow were also similar at LA as at C (Figure 5). Copper was never detected, and $\mathrm{Cr}$ was just at the detection limit in only one of the three samples collected in July 1998 (Figures 6g and 6h). Iron was at a quantifiable level $(>5 \mu \mathrm{g} / \mathrm{L}$ ) only during the 1997 events, which were in the late summer and fall (Figure 6i). Rather than not showing up in 1998 as it did at site C, Mn at LA was at its highest concentration at the early portion of runoff in 1998 (Figure 6m). It was detectable also in July 1997, but otherwise below the PQL. Except for a couple of the 3 samples collected on July 3, 1997, all samples at LA had Zn concentrations at less than the $0.3 \mu \mathrm{g} / \mathrm{L} \mathrm{PQL}$ (Figure 6r).

Arsenic at LA did not show a correlation $(\mathrm{r}=0.41, \mathrm{p}=0.31)$ with streamflow (Figures $5 \mathrm{c}$ and $6 \mathrm{~d}$ ). Concentrations were relatively constant at about $0.4 \mu \mathrm{g} / \mathrm{L}$ in most of the samples, other than in the 7/3/97 samples, which had As levels of $0.6 \mu \mathrm{g} / \mathrm{L}$. Sulfur was anomalous in that it followed the counter-clockwise hysteresis loop similar to that of the other major elements, although its concentration did not rise with the decrease in streamflow at the last sampling event, in July, 1998 (Figures 51 and 6o). pH does not have a clear relationship with streamflow at LA either, although a slight decrease in $\mathrm{pH}$ was detected during spring runoff in 1998 (Figure 6b).

As at site C, elemental loads at site LA followed the same trend as did streamflow, again indicating that changes in streamflow levels are by far more important than elemental concentrations in influencing the loading of dissolved elements through the site (Figures 6a and 7).

\section{3) Landers Fork at LB:}

At site LB, the hysteresis patterns are not nearly as clear as those seen upstream at $\mathrm{C}$ and LA, despite the additional five months of sampling at the site (Figures 8 and 9). Overall, inorganic carbon, $\mathrm{Ba}, \mathrm{Ca}, \mathrm{K}, \mathrm{Li}, \mathrm{Mg}, \mathrm{S}, \mathrm{Si}$, and $\mathrm{Sr}$ show an inverse relationship $(\mathrm{r}<-0.64, \mathrm{p}<0.01)$ to streamflow, and hysteresis cycling is either absent or only weakly apparent (Figure 8b, d, e, g, h, i, l, m). For many of these elements, a bottoming-out of the concentrations is visible at ca. $6000 \mathrm{~L} / \mathrm{s}$. That is, after streamflow levels reached ca. $6000 \mathrm{~L} / \mathrm{s}$, concentrations were maintained at a relatively uniform level compared with the large variability of concentrations during lower flows. 
As discussed in the Streamflow Results section, site LB was spring fed for several months prior to runoff in the late spring and summer. In April, 1998, when streamflow was still very low $(<113 \mathrm{~L} / \mathrm{s})$, concentrations of $\mathrm{Ca}$ and $\mathrm{S}$ rose before being diluted by snowmelt in May and June (Figures 9f and 9o). This rise could be explained by a flushing effect at the very start of runoff. This idea postulates that elements which have been accumulating in adjacent soil and ground water over the winter are suddenly released into the surface water creating a brief surge in concentrations (Edwards, 1973; Walling and Foster, 1975; Johnson and East, 1982).

Arsenic had a significantly positive relationship with $(\mathrm{r}=0.66, \mathrm{p}<0.01)$ (Figure 8c). Its lowest concentrations were present during the low flow periods of the late winter months (Figure 9d). Copper was not detected above its PQL of $0.8 \mu \mathrm{g} / \mathrm{L}$ (Figure 9h). Chromium showed up only occasionally above the PQL in some of the samples, but never in all three samples from a single site, indicating it may be primarily colloidal or that the $\mathrm{Cr}$ PQL was not well enough defined (Figure 9g). Similarly to site LA, Fe was at detectable levels only through January, 1998 (Figure 9i). It did not rise above the PQL in the fall of 1998 as it did in 1997. As at site LA, Mn was found in the late summer of 1997, and only at the highest flow event in 1998 (Figure 9m). Hence, the high flow appears to mobilize and not dilute Mn concentrations at both LA and LB. Zn concentrations at LB were all below the level found in the highest field blank, and so trends cannot be explained (Figure 9r). The $\mathrm{pH}$ at LB was generally higher in the summers of 1997 and 1998 than during other times of the year (Figure 9b).

Loads at LB are streamflow-dominated (Figure 10).

\section{4) Landers Fork at LC:}

The surface water geochemistry at site LC (Figures 11, 12, and 13) is generally similar to that of site LB, with some exceptions. A thaw flushing effect might explain a small rise in $\mathrm{Ca}$ and $\mathrm{Mg}$ in March and early April, 1998, just before spring runoff at the site (Figures 12f, and 12l). In general, inorganic carbon, $\mathrm{Ba}, \mathrm{Ca}, \mathrm{K}, \mathrm{Li}, \mathrm{Mg}, \mathrm{Si}$, and $\mathrm{Sr}$ exhibited similar trends over the course of the study period, with approximately negative relationships ( $r>-0.77, \mathrm{p}<0.01)$ with streamflow (Figure $11 \mathrm{~b}, \mathrm{~d}, \mathrm{e}, \mathrm{g}, \mathrm{h}, \mathrm{i}, \mathrm{m}$, and $\mathrm{n}$ ). As at site LB, the concentrations of many of these elements cease decreasing beyond a certain level of streamflow. At this site, this appears to occur at about $8000 \mathrm{~L} / \mathrm{s}$, which is approximately 10 times the baseflow level.

As at the upstream sites, $\mathrm{Cu}$ was always below the PQL at LC, and like at site LB, Mn was quantifiable only during the high flow events of both summers 1997 and 1998 (Figures $12 \mathrm{~h}$ and $12 \mathrm{~m}$ ). Chromium was detected in all three site replicate samples on 11/16/97, 1/6/98, and then again during the highest flow in 1998, on 6/29/98 (Figure 12g). As at the upstream sites, Fe at LC was detected no later than January, 1998 (Figure 12i). Arsenic concentrations were approximately twice as high at LC than at LB, reaching a maximum of $1.0 \mu \mathrm{g} / \mathrm{L}$ in early 1998 (Figure 12d). During this time, streamflow at site LC was dominated by ground water input, and the seeps measured near the site had As concentrations of 0.9-1.0 $\mu \mathrm{g} / \mathrm{L}$ (except for during November and December, 1998, when the seep concentrations were $0.5 \mu \mathrm{g} / \mathrm{L}$ ) (Table 9). As can been seen on Figure 11c, a range of As concentrations (from 0.4 to $1.0 \mu \mathrm{g} / \mathrm{L}$ ) was present during low flow conditions at the site. However, during the rest of the time, concentrations were mostly restricted to the 0.4 to $0.6 \mu \mathrm{g} / \mathrm{L}$ range, and there was no significant correlation between As and streamflow ( $\mathrm{r}=$ $-0.40, \mathrm{p}=0.11)$.

Dissolved S again behaved anomalously; and it did not correlate well with streamflow $(r=-0.48, p=0.05)$. It maintained a relatively steady concentration over the 
course of the dynamic streamflow conditions of 1998 (Figure 12o). Also not exhibiting a strong relationship to streamflow was $\mathrm{pH}$, although $\mathrm{pH}$ was generally lower in the winter of 1997 to spring of 1998, when the site was ground water fed (Figure 12b). The seeps at the site had $\mathrm{pH}$ levels that were lower than the surface water $(7.1-7.8$ compared to 7.7 8.3), which could explain the lower winter $\mathrm{pH}$ levels at the site. The $\mathrm{pH}$ values remained relatively low at the start of runoff, and then rose in June (Figure 12b). Fall measurement of $\mathrm{pH}$ at the site were at levels similar to pre-runoff conditions.

The highest loading of dissolved elements at site LC again occurred during high streamflow levels, as evident on Figure 13 compared to Figure 12a.

\section{5) Landers Fork at LD:}

As mentioned in the streamflow section, site LD was not sampled during the rise of runoff in 1998, and not beyond August, 1998. For the most part, concentrations at LD were very similar to those upstream at site LC when both sites were measured (Table 9). Therefore, the apparently different trends seen on the plots of data from LC and LD are simply an artifact of the presence of fewer datapoints at site LD (Figures 11-16). As at LC, inorganic carbon, $\mathrm{Ba}, \mathrm{Ca}, \mathrm{K}, \mathrm{Li}, \mathrm{Mg}, \mathrm{Si}$, and $\mathrm{Sr}$ had negatively sloping correlations with streamflow $(r<-0.69, p<0.04)$ and counter-clockwise hysteresis loops (Figure 14b, d, e, $\mathrm{g}, \mathrm{h}, \mathrm{i}, \mathrm{m}$, and $\mathrm{n})$.

\section{b) Blackfoot River and Hogum Creek}

\section{1) Blackfoot River at BH:}

At site $\mathrm{BH}$, a counter-clockwise hysteresis with a negative slope $(\mathrm{r}<-0.60, \mathrm{p}<0.05)$ to streamflow is seen for inorganic carbon, $\mathrm{Ba}, \mathrm{Ca}, \mathrm{Li}$, and $\mathrm{Si}$, (Figure 17b,d,e,h, and m). Potassium and $\mathrm{Mg}$ also correlate inversely with streamflow $(\mathrm{r}<-0.78 ; \mathrm{p}<0.01)$, but the falling and rising limbs are not distinct from one another in this dataset (Figures $17 \mathrm{~g}$ and 17i). Dissolved As shows a counter clockwise hysteresis as well, although the loop has neither a positive nor negative trend $(\mathrm{r}=0.12, \mathrm{p}=0.72)$ with streamflow (Figure 17c). Hence, As concentrations could be better predicted using rising limb vs. falling limb information rather than the streamflow values alone.

The $\mathrm{pH}$ at the site always was well above neutral (between 7.8 and 8.4), and the lowest $\mathrm{pH}$ values occurred on the post-rain storm sampling day (7/20/97) and during spring runoff in 1998 (Figure 18b). Arsenic, $\mathrm{Cu}, \mathrm{Fe}$, and Mn exhibit a reaction to the storm in July, 1997 as well, by being the most highly concentrated on that sampling event than on any other over the 14 month study at the site (Figure 18d,h,i, and m). Although As was somewhat diluted by the high flows in the spring and summer of 1998, dissolved $\mathrm{Fe}, \mathrm{Mn}$, and $\mathrm{Zn}$ concentrations increased with the runoff. Copper was not detected other than on the post-storm date and in 1 of 3 samples on each sampling date in July and August 1998 (Figure 18h). Chromium concentrations appeared above the PQL during a few of the low flow events, but not during spring runoff (Figure 18g).

Zinc concentrations were highest in late April, 1998, at the early portion of spring runoff, and overall, $\mathrm{Zn}$ correlated positively with streamflow $(r=0.79, \mathrm{p}<0.01)$ (Figures $17 \mathrm{o}$ and 18r). Sulfur behaved similarly to $\mathrm{Zn}$, in that its highest value was in late April, 1998 as well (Figure 180). In late April and May, 1998, its value was 2-4 times the

concentrations found during the rest of the study period. During the $6 / 5 / 98$ and $7 / 20 / 98$ 
sampling, when streamflow was still high due to runoff, S concentrations were relatively similar to pre-runoff conditions and Zn concentrations decreased. Hence, it appears that $S$ and Zn were "flushed" from the system during the early part of the spring snowmelt.

Plots of solute loads at the site indicate that like elsewhere, the amount of streamflow is the strongest influence on load quantities (Figures 18 a and 19). However, variations in the chemical concentrations of elements also play a role. For example, the $\mathrm{S}$ load did not increase with the second runoff peak sampled on 6/5/98; because its

concentration dropped so dramatically after the start of runoff, its load continued to drop as well despite the rise in streamflow (Figure 19e). This same phenomenon is visible for the $\mathrm{Zn}$ loads; although the second runoff peak is detectable via the rise in $\mathrm{Zn}$ loads, the second peak is not as high as the first one, even though the streamflow level had increased (Figure 19d).

\section{2) Hogum Creek:}

Hogum Creek was sampled less often than most other sites-- only seven times and only between November 1997 and August, 1998 (Figure 21a). Nonetheless, this time period captured at least one pre-, during- and post runoff event. Results show that most detectable elements $(\mathrm{Ba}, \mathrm{Ca}, \mathrm{K}, \mathrm{Li}, \mathrm{Mg}, \mathrm{Mn}$, and $\mathrm{Sr})$ correlated negatively $(\mathrm{r}<-0.82$, $\mathrm{p}<0.03$ ) with streamflow (Figures 20c,d,f,g,h,i, and $\mathrm{m}$ ). Although a hysteresis pattern is difficult to discern from the data, there appears to be a slight counter clockwise rotation (falling limb has higher concentrations than rising limb) for the $\mathrm{Ba}, \mathrm{K}$, and $\mathrm{Li}$ concentrations, and a clockwise rotation (rising limb more highly concentrated than falling $\mathrm{limb}$ ) for $\mathrm{Ca}, \mathrm{Mg}$, and $\mathrm{Mn}$.

Elements that did not correlate negatively with streamflow were As, S, and $\mathrm{Si}$ ( $p>0.31$ ) (Figures 20b,k, and 1). Arsenic was peculiar in that it went from being at the PQL of $0.2 \mu \mathrm{g} / \mathrm{L}$ during November, 1997 and January, 1998, to increasing steadily through the end of the sampling period, when it measured $1.1 \mu \mathrm{g} / \mathrm{L}$ on $8 / 17 / 98$ (Figure 21d). This indicates that the physical and/or chemical sources to Hogum Creek in the winter months were more depleted in As than the sources that played increasingly larger roles in the summer. Sulfur exhibits a trend roughly opposite to that of As, in that its concentration dropped over the course of the study period (Figure 210). It was close to 3 $\mathrm{mg} / \mathrm{L}$ in November, 1997, January, 1998, and April, 1998. In May, 1998, it dropped to $2.5 \mathrm{mg} / \mathrm{L}$, and in June, July, and August it was at $1.1-1.4 \mathrm{mg} / \mathrm{L}$. Thus, similarly to other sites, $\mathrm{S}$ at $\mathrm{HC}$ was low in the summer after the start of runoff, possibly indicating a flushing phenomenon again. Sulfur had clockwise rotation and Si had counterclockwise rotation at the site with no linear relationship to streamflow. Iron also did not follow the trends the other elements did; although it showed a slight negative relationship with discharge for most of the study period, the last sample collected (in August, 1998) was 3-4 times as high in Fe as all the other samples (Figure 21i). Zinc was below the PQL of 0.3 $\mu \mathrm{g} / \mathrm{L}$ for all but the November and January samples, but even those were lower than the measurement of the highest field blank (Figure 21r). The $\mathrm{pH}$ at $\mathrm{HC}$ was between 7.3 and 7.6, although it was higher (at 8.0 and 7.8) at the last two sampling events, in July and August, 1998, on the falling limb of the hydrograph (Figure 21b).

\section{3) Blackfoot River at BB:}

Many of the same geochemical trends discussed at site BH are apparent at site BB. Many elements correlate inversely with streamflow $(\mathrm{r}<-0.64, \mathrm{p}<0.02)$. However, the highest flow sample, taken when streamflow was at ca. $6000 \mathrm{~L} / \mathrm{s}$, was hardly different than the samples taken at ca. $2000 \mathrm{~L} / \mathrm{s}$. This may indicate that beyond a certain flow threshold, 
meltwater overwhelms baseflow contributions. There was a wide amount of variation in dissolved concentrations during low flow conditions, and relatively little geochemical variation at higher flows. Inorganic carbon, $\mathrm{Ba}, \mathrm{Li}, \mathrm{Si}$, and $\mathrm{Sr}$ appear to follow a counterclockwise hysteresis pattern, while $S$ follows in a clockwise direction (Figures 23 $\mathrm{b}, \mathrm{d}, \mathrm{e}, \mathrm{i}, \mathrm{j}, \mathrm{k}, \mathrm{o}$, and p). Also similar to site BH, As at BB exhibits a counter clockwise hysteresis cycle with no positive or negative trend with streamflow $(r=0.29, p=0.29)$ (Figure 23c). However, many of the hysteresis cycles for these and other solutes are unclear, with falling and rising limb points not always being distinct from one another. For example, $\mathrm{Ca}$ and $\mathrm{Mg}$ exhibit clockwise hysteresis when considering the 1998 data only, but when adding the fall 1997 data, the hysteresis loop is no longer valid because the 1997 falling limb points overlap with the 1998 rising limb points.

Site BB's reaction to the storm immediately before the 7/20/97 sample is seen as a drop in $\mathrm{pH}$ and an increase in $\mathrm{Cu}$ and Fe (Figures 24b,h, and i). However, while many trace elements were at higher concentrations following the storm in 7/97, only Fe was at its maximum on that event compared the whole study period. Generally, Fe correlated poorly with streamflow $(r=0.05 ; p=0.86)$ although its lowest values were found in the $6 / 29 / 98$ samples, when streamflow was the highest. Copper showed up above its PQL not only after the storm, but also in some of the late spring and summer samples of 1998 (Figure 24h). In fact, its maximum concentration was collected during the highest flows measured, in late June, 1998. Manganese typically changed little with streamflow, but overall there is a slightly positive relationship ( $\mathrm{p}=0.02$ ) between $\mathrm{Mn}$ and streamflow (Figure 231) Arsenic was higher in the late summers of 1997 and 1998 than during other times of the study, when its concentrations followed no discernable pattern (Figure 24d). The $\mathrm{pH}$ values at BB were not clearly correlated with streamflow either, although they were lower at the start of 1998's spring runoff than they were before and after (Figure 24b).

As at site $\mathrm{BH}, \mathrm{S}$ and $\mathrm{Zn}$ at BB peaked during the early stages of runoff (Figures $24 \mathrm{o}$ and r). However, while $\mathrm{S}$ returned to pre-runoff levels shortly after the start of high flow, $\mathrm{Zn}$ remained at relatively high levels during the course of runoff. Sulfur concentrations in April to May were approximately 3 times as high as during the rest of the study period. Dissolved Zn was relatively high not only during runoff in 1998, but also during the two July, 1997 sampling events. The early spring runoff mobilizations of dissolved $\mathrm{Zn}$ and $\mathrm{S}$ are evident in the load plots (Figure 25).

\section{4) Blackfoot River at BC:}

Dissolved inorganic carbon, $\mathrm{Ba}, \mathrm{K}, \mathrm{Li}, \mathrm{Si}$, and $\mathrm{Sr}$ at site $\mathrm{BC}$ exhibit counterclockwise hysteresis similar to that seen upstream at BB and BH (Figures 26b,d, g, h, m, and $\mathrm{n}$ ). Again, they (and $\mathrm{Ca}$, and $\mathrm{Mg}$ ) have a generally negative relationship $(\mathrm{r}<-0.52$, $\mathrm{p}<0.05$ ) to streamflow, with high variability in concentrations during low flow periods. As at sites LB, LC, and BB, there appears to be a bottoming-out of solute concentrations during high flow periods (e.g. Figures 26e and h). This may again indicate that beyond a certain flow threshold, meltwater overwhelms the baseflow contributions.

Site BC was first sampled on 7/20/97, the event that immediately followed the summer storm referred to before. These first samples at BC are relatively low in $\mathrm{pH}$ and high in As, Fe, Mn, and Zn (Figures 27b,d,i, m, and r). Like at the other sites, dissolved As at $\mathrm{BC}$ was variable $(0.2-0.5 \mu \mathrm{g} / \mathrm{L})$ during low flow conditions and it did not have a negative or positive relationship to streamflow overall $(\mathrm{r}=0.04, \mathrm{p}=0.88)$ (Figures 26c and 27d). The highest Fe found at the site over the study period was on the first sampling date, the post-storm event (Figure 27i). Copper was detected only during the highest flow level measured at BC, on 6/29/98 (Figure 27h). Cr was found barely above its PQL in the 
November 1997 and Januray 1998 samples, as well as in one of the three from 6/29/98 (Figure $27 \mathrm{~g})$. Dissolved $\mathrm{Mn}$ at BC had a remarkably good positive correlation $(\mathrm{r}=0.91$, $\mathrm{p}<0.01$ ) with discharge (Figure 26j). Dissolved Zn appears to have been mobilized by spring runoff as well, with its highest concentrations occurring in the samples collected during the highest flows (Figure 260 and $27 \mathrm{r}$ ). The $\mathrm{pH}$ levels at $\mathrm{BC}$ were variable within the 7.7 to 8.3 range, although $\mathrm{pH}$ was clearly lower at the start of runoff than at the end (Figure 27b).

Following along with the trends at $\mathrm{BH}$ and $\mathrm{BB}$, concentrations of dissolved $\mathrm{S}$ and Zn were observed to rise during the early stages of spring runoff in 1998 (Figures 27o and $27 \mathrm{r}$ ). Concentrations during the peak of runoff are lower than those during the start, indicating a flushing of these solutes into the river with the onset of snowmelt.

\section{Summary}

Streamflow levels and surface water- ground water dynamics varied seasonally at the sites along the Landers Fork and Blackfoot River drainages studied in this project. We began this project towards the end of spring runoff in 1997, and we sampled the sites through the following winter and spring runoff.

$>$ Streamflow data from the Copper Creek and Landers Fork sites (LA and LB) show that the stretch of river between the sites is disconnected during the low flow winter period. Although Copper Creek was free flowing at all times other than in early March, 1998, site LA was dry for much of the winter.

$>$ Streamflow generated from ground water seeps sustained ice-free flow in the Landers Fork at sites LB and LC at all times of the year. The reach between LB and LC was gaining streamflow during all 17 times that both sites were gauged between July, 1997 and November, 1998.

$>$ At the Blackfoot River sites, streamflow was present at all sites every time they were visited over the course of the study. The one exception to this is site BB, where the river was frozen over on 1/6/98. The ice-free streamflow at sites $\mathrm{BH}$ and $\mathrm{BC}$ during the cold winter months indicate an important role by the local or regional ground water system in sustaining streamflows in the area.

$>$ The stretch between $\mathrm{BH}$ and $\mathrm{BC}$ was a losing reach most of time it was measured. However, the stretch of river between sites $\mathrm{BB}$ and $\mathrm{BC}$ was gaining streamflow the majority of the times the sites were gauged.

$>$ The concentrations of dissolved $(<0.2 \mu \mathrm{m})$ elements measured at the sites indicate that the Blackfoot River had higher mean concentrations of $\mathrm{Cu}, \mathrm{Fe}, \mathrm{K}, \mathrm{Mn}, \mathrm{Na}, \mathrm{S}, \mathrm{Si}, \mathrm{Sr}$, and $\mathrm{Zn}$ than the Landers Fork; lower concentrations of inorganic carbon, $\mathrm{Ba}$, and $\mathrm{Ca}$ than the Landers Fork; and similar concentrations of $\mathrm{As}, \mathrm{Li}$, and $\mathrm{Mg}$ as the Landers Fork.

$>$ A counter-clockwise, negatively trending hysteresis effect was present for many elements along Copper Creek, and for only a few in the Landers Fork. Although hysteresis cycles were unclear for most solutes at the Landers Fork sites, many solute concentrations correlated inversely with streamflow. 
The dissolved trace metals $\mathrm{Cu}, \mathrm{Cr}, \mathrm{Fe}, \mathrm{Mn}$, and $\mathrm{Zn}$ were usually or always below detection levels at Landers Fork sites. However, Mn was detected during the highest flow measured in 1998. Arsenic was not well correlated with streamflow at any of the sites.

During the low flow winter months, the geochemistry at sites LB and LC was largely influenced by the chemistry of the seeps supplying much of the flows, and a small surge in concentrations of several elements was detected at an early stage of spring runoff.

At the Blackfoot River sites, a counter-clockwise hysteresis with a negative relationship to streamflow was detected for many of the non-trace metals. At BB and BC, a leveling out of concentrations is seen at the higher flow levels.

$>$ Unlike in the Landers Fork, many of the trace metals in the Blackfoot were well above their detection limits, allowing for characterization of their trends with time. Trace metals such as $\mathrm{Cu}, \mathrm{Fe}, \mathrm{Mn}, \mathrm{S}$, and $\mathrm{Zn}$ regularly were at higher concentrations during spring runoff in 1998, and they were also elevated following a rainstorm in July, 1997. Sulfur and $\mathrm{Zn}$ appeared to be mobilized during the early stages of runoff. Manganese correlated particularly well with streamflow at site BC. Like at the Landers Fork sites, a haphazard relationship between streamflow and As is seen along the Blackfoot.

$>$ It is unknown whether the observed increases in some trace elements in both the Landers Fork and Blackfoot Rivers during high flow events were due to increased passage of colloids through the filters or due to geochemical and hydrologic source variations that increased concentrations of truly dissolved elements.

$>$ Considerable hydrological and geochemical variation existed among sites within the relatively short river segments studied $(<7 \mathrm{kms})$, indicating the importance of defining small-scale spatial and temporal variations in rivers subjected to baseline characterization studies.

$>$ In summary, this report presents the results of up to 18 months of baseline geochemical studies in the upper Blackfoot and lower Landers Fork watersheds. Streamflow levels alone were poor predictors of solute geochemistry in the Landers Fork and upper Blackfoot River. The location on the side of the hydrograph peak(s) appears to be at least as important as knowing the streamflow level for many elements at the sites studied. Many trace metals were mobilized during high flow events in the Blackfoot River. A geochemical signal of the presence of the undeveloped McDonald ore body was not apparent in the water quality data for the Landers Fork.

More detailed temporal studies would be helpful to better understand issues of early spring runoff flushing, storm geochemistry versus spring runoff geochemistry (especially for the trace metals), and the perplexing haphazardness of arsenic concentrations in both watersheds. 


\section{$\underline{\text { References }}$}

Benoit, G., 1994, Clean technique measurement of $\mathrm{Pb}, \mathrm{Ag}$, and $\mathrm{Cd}$ in freshwater: a redeifintion of metal pollution. Environ. Sci. Tech. 28(11): 1987, 1991.

Bhangu, I. and P.H. Whitfield, 1997, Seasonal and long-term variations in water quality of the Skeena River at Usk, British Columbia. Water Research 31 (9): 2187-2194.

Bird, S.C. The effect of hydrological factors on trace metal contamination in the river Tawe, South Wales. Environmental Pollution, 45, 87-124, 1987.

Droppo, I. G. and C. Jaskot, Impact of river transport characteristics on contaminant sampling error and design, Environ. Sci. Technol. 29: 161-170, 1995.

Edwards, A.M.C., 1973, The variation of dissolved constituents with discharge in some Norfolk rivers, J. Hydrology, 18: 219-242.

Evans, C. and T.D. Davies, 1998, Causes of concentration/discharge hysteresis and its potential as a tool for analysis of episode hydrochemistry. Water Resources Research 34(1): 129-137.

Franson, M.A. H. (ed.), 1985, American Public Health Association, American Water Works Association, and Water Pollution Control Federation, Standard methods for the examination of water and wastewater, a) Organic carbon (total), combustion-infrared method, p 507-511, b) Determination of arsenic and selenium by conversion to their hydrides by sodium borohydride reagent and aspiration into an Atomic Absorption Atomizer; p. 165-171.

Johnson, R.A., and J.W. East, Cyclical relationships between river discharge and chemical concentration during flood events. J. Hydrology, 57: 93-106, 1982.

Martin, T.D., C.A. Brockhoff, J.T. Creed, 1994, Determination of metals and trace metals in water by Ultrasonic Nebulization Inductively Coupled Plasma-Atomic Emission Spectrometry (200.15). Environmental Monitoring Systems Laboratory, Office of Research and Development, U.S. Environmental Protection Agency.

Menges, J. L., 1997, Investigation of temporal changes of heavy metal concentrations in sediments and water of the Blackfoot River, Montana. Unpublished M.S. thesis, University of Montana, $163 \mathrm{p}$.

Moore, J.N., S.N. Luoma, D. Peters, 1991, Downstream effects of mine effluent on an intermontane riparian system, Can. J. Fish. Aquat. Sci. 48: 222-232.

Nagorski, S.A., J.A. Shifflett, J.N. Moore, and D.B. Smith, 1998, Geochemical baseline studies and relations between water quality and streamflow in the Upper Blackfoot River watershed, Montana: Progress report for July 1997- March 1998. U.S. Geological Survey Open-File Report 98-499, 133 p.

Nagorski, S.A., T.E. McKinnon, J.N. Moore, and D.B. Smith, 2000, Geochemical characterization of surface water and streambed sediment of the Blackfoot River, Montana, during low flow conditions, August 16-20, 1998. U.S. Geological Survey Open-File Report 00-003, 59 p. 
Pfaff, J.D., 1993, Determination of inorganic anions by Ion Chromatography (300.0). EPA methods for determination of inorganic substances in environmental samples.

EPA/600/R-93/100.

Schafer and Assiates, Final surface water baseline characterization report for the Seven-Up Pete Joint Venture McDonald Project. Submitted to Seven-Up Pete Joint Venture, 1994.

Taylor, H.E. and A.M. Shiller, 1995. Mississippi River methods comparison study: Implications for water quality monitoring of dissolved trace elements. Environ. Sci. Technol. 29(5): 1313-1317.

Walling, D.E. and I.D.L. Foster, Variations in the natural chemical concentration of river water during flood flows, and the lag effect: Some further comments. J. Hydrology 26: 237-244, 1975.

Windom, H.L., J.T. Byrd, G. Smith, and F. Huan, 1991, Inadequacy of NASQAN data for assessing trace metal trends in the nation's rivers. Environ. Sci. Technol. 25(6): 11371142. 
Table 1: DISCHARGE MEASUREMENTS [cubic feet per second]

${ }^{*} \mathrm{NM}=$ Not measured; $N R=$ Not recorded
in italics: sample not taken with Q measurement

\begin{tabular}{|c|c|c|c|c|c|c|c|c|c|c|c|c|c|c|c|c|c|c|c|c|c|c|c|}
\hline SITE & $7^{7 / 3 / 97-7}$ & $\begin{array}{l}\text { I/4/97 } \\
\text { replicate } \\
\text { transect }\end{array}$ & $7 / 20 / 1997$ & $\begin{array}{l}\text { replicate } \\
\text { transect }\end{array}$ & $\begin{array}{l}\text { replicat } \\
\text { transect }\end{array}$ & $7 / 21 / 1997$ & $\begin{array}{l}\text { replict } \\
\text { transe }\end{array}$ & te replicate & $e^{8 / 7 / 97-8 / 81}$ & $\begin{array}{l}197 \\
\text { replicate } \\
\text { transect }\end{array}$ & \begin{tabular}{|l} 
9/6/1999 \\
\end{tabular} & $\begin{array}{l}\text { replicate } \\
\text { transect }\end{array}$ & $9 / 13 / 97$ & $\begin{array}{l}7-9 / 14 / 97 \\
\text { replicate } \\
\text { transect } \\
\end{array}$ & \begin{tabular}{|l|}
$\begin{array}{l}\text { replicate } \\
\text { transect }\end{array}$ \\
\end{tabular} & $\begin{array}{r}11 / 16 / 97,11 / 18 / 97 \\
\text { replicate } \\
\text { transect }\end{array}$ & $1 / 6 / 1998$ & 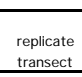 & $3 / 8 / 1998$ & 4/7/1998 & \begin{tabular}{|l|}
$\begin{array}{c}\text { replicate } \\
\text { transect }\end{array}$ \\
\end{tabular} & ]$^{4 / 26 / 1998}$ & $\begin{array}{l}\text { replicate } \\
\text { transect }\end{array}$ \\
\hline 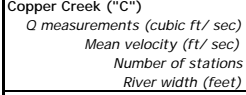 & \begin{tabular}{|l}
163 \\
3.6 \\
18 \\
32 \\
\end{tabular} & $\begin{array}{l}161 \\
3.6 \\
17 \\
31\end{array}$ & $\begin{array}{l}117 \\
2.7 \\
14 \\
34 \\
\end{array}$ & $\begin{array}{l}108 \\
2.5 \\
14 \\
34 \\
\end{array}$ & $\begin{array}{l}113 \\
2.6 \\
14 \\
34 \\
\end{array}$ & $\begin{array}{l}99 \\
2.5 \\
\text { (NR) } \\
35 \\
\end{array}$ & & & $\begin{array}{l}52 \\
1.8 \\
15 \\
33 \\
\end{array}$ & $\begin{array}{l}51 \\
1.8 \\
14 \\
33 \\
\end{array}$ & (NM) & & $\begin{array}{l}25 \\
12.3 \\
14 \\
29.5 \\
\end{array}$ & $\begin{array}{l}23 \\
1.2 \\
14 \\
29.5 \\
\end{array}$ & & (NM) & $\begin{array}{l}14 \\
1.1 \\
10 \\
16.5 \\
\end{array}$ & $\begin{array}{l}16 \\
1.2 \\
9 \\
16.5 \\
\end{array}$ & (frozen) & $\begin{array}{l}14 \\
1.03 \\
13 \\
27 \\
27\end{array}$ & $\begin{array}{l}15 \\
1.05 \\
13 \\
27 \\
\end{array}$ & $\begin{array}{l}28 \\
1.5 \\
14 \\
30\end{array}$ & $\begin{array}{l}28 \\
1.44 \\
14 \\
30 \\
\end{array}$ \\
\hline \begin{tabular}{|c} 
Landers Fork A ("LA") \\
Q measurements (cubic ft/ sec) \\
Mean velocity (ft/ sec) \\
Number of statitons \\
River width (feet)
\end{tabular} & $\begin{array}{l}1114 \\
2.3 \\
22 \\
43.5\end{array}$ & $\begin{array}{l}11.6 \\
2.3 \\
22 \\
43.5\end{array}$ & $\begin{array}{l}84 \\
24.3 \\
15 \\
40\end{array}$ & $\begin{array}{l}85 \\
2.3 \\
15 \\
40\end{array}$ & & (NM) & & & $\begin{array}{l}38 \\
1.7 \\
14 \\
32\end{array}$ & $\begin{array}{l}40 \\
1.8 \\
13 \\
32\end{array}$ & (NM) & & $\begin{array}{l}16 \\
1.1 \\
16 \\
30\end{array}$ & $\begin{array}{l}16 \\
1.1 \\
16 \\
30\end{array}$ & & (NM) & (frozen) & & (frozen) & 10 & & $\begin{array}{l}33 \\
1.73 \\
128 \\
28\end{array}$ & $\begin{array}{l}31 \\
1.57 \\
14 \\
30\end{array}$ \\
\hline \begin{tabular}{|r} 
Landers Fork B ("IB") \\
Q meas. (maintside channels) \\
Mean velocity (ft/ sec) \\
Number of tstations \\
River width (feet)
\end{tabular} & $\begin{array}{l}\text { Totot. Q=3 } \\
223+98 \\
3.1 \\
20 \\
51 \\
51 \\
\end{array}$ & $\begin{array}{l}303 \text { to } 332) \\
226+(98) \\
2.9 \\
16 \\
51 \\
\end{array}$ & $\begin{array}{l}\text { (Tot. Q=191 } \\
122+69 \\
22.211 .5 \\
15 ; 12 \\
45 ; 35 \\
45\end{array}$ & $\begin{array}{l}\text { to } 198) \\
124+74 \\
2.2 ; 1.5 \\
15 ; 12 \\
45 ; 35 \\
\end{array}$ & & $\begin{array}{l}\mid \text { (main channel } \\
117+(\mathrm{NM}) \\
2.2 ; \text { (NM) } \\
15 ;(\mathrm{NM}) \\
45 ; \text { (NM) } \\
\end{array}$ & & & \begin{tabular}{|l} 
(Tot. $Q=95 \mathrm{t}$ \\
$86+4+6$ \\
$1.8 ; 1.3 ; 0.6$ \\
$11 ; 8 ; 8$ \\
$38 ; 13 ; 11$ \\
\end{tabular} & 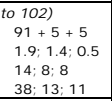 & \begin{tabular}{|l}
47 \\
2.02 \\
13 \\
23 \\
\end{tabular} & $\begin{array}{l}50 \\
1.50 \\
15 \\
35\end{array}$ & \begin{tabular}{|l} 
(Tot. $\mathrm{Q}=$ \\
$38+1$ \\
$0.9 ; 0.8$ \\
$15+5$ \\
$37+5$ \\
$7+5$
\end{tabular} & $\begin{array}{l}=38 \text { to } 39) \\
37+1 \\
0.9 ; 0.5 \\
15+5 \\
37+5.5 \\
\end{array}$ & & $\begin{array}{l}11 \\
0.8 \\
14 \\
25 \\
\end{array}$ & $\begin{array}{l}6 \\
0.7 \\
11 \\
21 \\
\end{array}$ & $\begin{array}{l}5 \\
0.6 \\
9 \\
21\end{array}$ & $\begin{array}{l}1 \\
0.2 \\
7 \\
19\end{array}$ & $\begin{array}{l}1 \\
0.52 \\
7 \\
7\end{array}$ & $\begin{array}{l}2 \\
0.62 \\
7 \\
7\end{array}$ & $\begin{array}{l} \\
0.46 \\
10 \\
19\end{array}$ & $\begin{array}{l}4 \\
0.47 \\
10 \\
19\end{array}$ \\
\hline \begin{tabular}{|c|} 
Landers Fork C ("LC") \\
Q measurements (cubic ft/ sec) \\
Mean velocity (ft/ sec) \\
Number of stations \\
River width (feet)
\end{tabular} & $\begin{array}{l}398 \\
3.4 \\
18 \\
53\end{array}$ & $\begin{array}{l}373 \\
3.2 \\
18 \\
53\end{array}$ & & & & $\begin{array}{l}227 \\
2.4 \\
18 \\
50\end{array}$ & $\begin{array}{l}225 \\
2.4 \\
23 \\
50\end{array}$ & $\begin{array}{l}227 \\
2.3 \\
19 \\
50\end{array}$ & $\begin{array}{l}133 \\
1.5 \\
20 \\
48\end{array}$ & $\begin{array}{l}128 \\
1.4 \\
19 \\
48\end{array}$ & $\mid \begin{array}{l}77 \\
1.01 \\
16 \\
43\end{array}$ & & $\begin{array}{l}64 \\
0.9 \\
16 \\
43\end{array}$ & $\begin{array}{l}68 \\
0.9 \\
16 \\
43\end{array}$ & & $\begin{array}{l}36 \\
0.6 \\
18 \\
41\end{array}$ & $\begin{array}{l}26 \\
0.6 \\
13 \\
33\end{array}$ & $\begin{array}{l}26 \\
0.6 \\
14 \\
34\end{array}$ & $\begin{array}{l}22 \\
0.6 \\
11 \\
32\end{array}$ & $\begin{array}{l}24 \\
0.6 \\
13 \\
32.5\end{array}$ & $\begin{array}{l}25 \\
0.63 \\
13 \\
32.5\end{array}$ & $\begin{array}{l}25 \\
0.61 \\
12 \\
34\end{array}$ & $\begin{array}{l}25 \\
0.6 \\
12 \\
34\end{array}$ \\
\hline \begin{tabular}{|r|} 
Landers Fork D ("LD") \\
Q measurements (ccubic ft/ sec) \\
Mean velocity (ft/ s sec) \\
Number of stations \\
River width (feet)
\end{tabular} & (NM) & & $\begin{array}{l}226 \\
2.8 \\
22 \\
48\end{array}$ & $\begin{array}{l}230 \\
\text { (NR) } \\
19 \\
48\end{array}$ & & $\begin{array}{l}228 \\
2.9 \\
15 \\
48\end{array}$ & & & $\begin{array}{l}116 \\
2.1 \\
15 \\
45\end{array}$ & $\begin{array}{l}112 \\
2.1 \\
15 \\
43\end{array}$ & (NM) & & $\begin{array}{l}54 \\
1.7 \\
16 \\
31\end{array}$ & $\begin{array}{l}49 \\
1.7 \\
17 \\
31\end{array}$ & & $\begin{array}{l}30 \\
1.32 \\
11 \\
29\end{array}$ & $\mid \begin{array}{l}25 \\
1.4 \\
10 \\
27\end{array}$ & & $\begin{array}{l}13 \\
1 \\
8 \\
23\end{array}$ & $\begin{array}{l}16 \\
1.17 \\
9 \\
27\end{array}$ & $\begin{array}{l}18 \\
1.16 \\
11 \\
27\end{array}$ & (NM) & \\
\hline 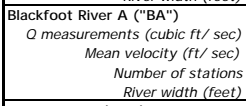 & $\mid \begin{array}{l}99 \\
1.8 \\
17 \\
\text { (NR) }\end{array}$ & $\begin{array}{l}94 \\
1.8 \\
17 \\
\text { (NR) }\end{array}$ & \begin{tabular}{|l}
74 \\
1.4 \\
18 \\
34.5 \\
\end{tabular} & $\begin{array}{l}80 \\
1.5 \\
14 \\
34.5 \\
\end{array}$ & & \begin{tabular}{|l}
67 \\
1.46 \\
14 \\
33 \\
\end{tabular} & & & \begin{tabular}{|l}
41 \\
1 \\
13 \\
34 \\
\end{tabular} & $\begin{array}{l}41 \\
1 \\
13 \\
34 \\
\end{array}$ & (NM) & & $\begin{array}{l}28 \\
0.8 \\
17 \\
31.5 \\
\end{array}$ & $\begin{array}{l}27 \\
0.8 \\
15 \\
31.5 \\
\end{array}$ & & (NM) & (NM) & & (NM) & (NM) & & (NM) & \\
\hline 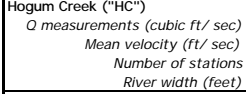 & (NM) & & (NM) & & & (NM) & & & (NM) & & (NM) & & (NM) & & & $\begin{array}{l}1 \\
0.7 \\
5 \\
3.5\end{array}$ & $\begin{array}{l}1 \\
0.8 \\
6 \\
4.5\end{array}$ & $\begin{array}{l}1 \\
0.6 \\
6 \\
4.5 \\
\end{array}$ & (frozen) & (NM) & & $\begin{array}{l}13 \\
1.97 \\
111 \\
11\end{array}$ & $\begin{array}{l}13 \\
1.67 \\
7 \\
11 \\
\end{array}$ \\
\hline \begin{tabular}{|c} 
Blackfoot River H ("BH") \\
Q measurements (cubic ft/ sec) \\
Mean velocity (ft/ sec) \\
Number of stations \\
River width (feet) \\
\end{tabular} & $\begin{array}{l}103 \\
1.2 \\
17 \\
\text { (NR) }\end{array}$ & $\begin{array}{l}111 \\
1.4 \\
17 \\
(\mathrm{NR})\end{array}$ & $\begin{array}{l}77 \\
1 \\
20 \\
49 \\
\end{array}$ & $\begin{array}{l}74 \\
0.9 \\
17 \\
49 \\
\end{array}$ & $\begin{array}{l}76 \\
0.9 \\
17 \\
49\end{array}$ & \begin{tabular}{|l}
64 \\
1 \\
11 \\
35.5 \\
\end{tabular} & $\begin{array}{l}68 \\
1.1 \\
12 \\
35.5 \\
\end{array}$ & & $\begin{array}{l}38 \\
0.7 \\
13 \\
38 \\
\end{array}$ & $\begin{array}{l}38 \\
0.8 \\
13 \\
38 \\
\end{array}$ & (NM) & & $\begin{array}{l}33 \\
0.5 \\
13 \\
30 \\
30\end{array}$ & $\begin{array}{l}31 \\
0.5 \\
11 \\
30 \\
\end{array}$ & & $\begin{array}{l}26 \\
2.0 \\
10 \\
23\end{array}$ & $\begin{array}{l}20 \\
0.9 \\
9 \\
18\end{array}$ & & $\begin{array}{l}23 \\
1.6 \\
11 \\
21 \\
21\end{array}$ & (NM) & & \begin{tabular}{|l}
79 \\
1.88 \\
115 \\
41 \\
1
\end{tabular} & $\begin{array}{l}77 \\
1.88 \\
16 \\
41 \\
\end{array}$ \\
\hline $\begin{array}{r}\text { Blackfoot River B ("BB") } \\
\text { Q measurements (cubic ft/ sec) } \\
\text { Mean velocity (ft/ sec) } \\
\text { Number of statitions } \\
\text { River width (feet) }\end{array}$ & $\begin{array}{l}102 \\
1.7 \\
20 \\
(\text { NRP }\end{array}$ & $\begin{array}{l}100 \\
1.7 \\
20 \\
\text { (NRP) }\end{array}$ & $\begin{array}{l}79 \\
1.3 \\
22 \\
56 \\
56\end{array}$ & $\begin{array}{l}79 \\
1.3 \\
23 \\
56\end{array}$ & & $\begin{array}{l}63 \\
1.3 \\
12 \\
40 \\
40\end{array}$ & $\begin{array}{l}66 \\
1.3 \\
12 \\
40\end{array}$ & & $\begin{array}{l}36 \\
0.9 \\
13 \\
40\end{array}$ & $\begin{array}{l}33 \\
0.8 \\
13 \\
40\end{array}$ & (NM) & & $\begin{array}{l}23 \\
1 \\
17 \\
53\end{array}$ & $\begin{array}{l}22 \\
0.9 \\
20 \\
53\end{array}$ & & $\begin{array}{l}21 \\
0.6 \\
19 \\
36 \\
36\end{array}$ & (frozen) & & (NM) & $\begin{array}{l}38 \\
1.66 \\
12 \\
26\end{array}$ & $\begin{array}{l}35 \\
1.52 \\
14 \\
26\end{array}$ & \begin{tabular}{|l}
72 \\
1.55 \\
14 \\
39 \\
39
\end{tabular} & $\begin{array}{l}77 \\
1.69 \\
14 \\
39\end{array}$ \\
\hline \begin{tabular}{|c|} 
Blackfoot River C ("BC") \\
Q measurements (ccubic ft/ sec) \\
Mean velocity (ft/ sec) \\
Number of stations \\
River width (feet)
\end{tabular} & (NM) & & $\begin{array}{l}100 \\
\text { (NR) } \\
15 \\
42\end{array}$ & $\begin{array}{l}107 \\
\text { (NR) } \\
13 \\
42\end{array}$ & & $\begin{array}{l}87 \\
1.8 \\
15 \\
42\end{array}$ & $\begin{array}{l}87 \\
1.7 \\
13 \\
42\end{array}$ & & $\begin{array}{l}52 \\
1.4 \\
14 \\
41\end{array}$ & $\begin{array}{l}50 \\
1.4 \\
14 \\
41\end{array}$ & (NM) & & $\begin{array}{l}29 \\
1.0 \\
16 \\
39\end{array}$ & $\begin{array}{l}33 \\
1.1 \\
17 \\
39\end{array}$ & $\begin{array}{l}29 \\
1.0 \\
20 \\
39\end{array}$ & $\mid \begin{array}{l}15 \\
0.7 \\
13 \\
33.5\end{array}$ & $\begin{array}{l}14 \\
0.7 \\
13 \\
36\end{array}$ & $\begin{array}{l}14 \\
0.7 \\
13 \\
36\end{array}$ & $\begin{array}{l}15 \\
0.8 \\
9 \\
34\end{array}$ & \begin{tabular}{|l}
40 \\
1.26 \\
16 \\
39
\end{tabular} & $\begin{array}{l}37 \\
1.15 \\
16 \\
39\end{array}$ & \begin{tabular}{|l}
80 \\
1.79 \\
16 \\
40
\end{tabular} & $\begin{array}{l}84 \\
1.87 \\
15 \\
40\end{array}$ \\
\hline \begin{tabular}{|c} 
Blackfoot River D ("BD") \\
Q measurements (cubic ft/ sec) \\
Mean velocity (ft/ sec) \\
Number of stations \\
River width (feet)
\end{tabular} & \begin{tabular}{|l}
334 \\
3.1 \\
19 \\
$1(\mathrm{NR})$ \\
\end{tabular} & & $\begin{array}{l}319 \\
2.8 \\
21 \\
65\end{array}$ & $\begin{array}{l}325 \\
2.8 \\
23 \\
65\end{array}$ & & $\begin{array}{l}299 \\
2.6 \\
24 \\
65\end{array}$ & $\begin{array}{l}301 \\
2.7 \\
18 \\
65\end{array}$ & & $\begin{array}{l}151 \\
1.9 \\
20 \\
63\end{array}$ & & (NM) & & $\begin{array}{l}78 \\
2.1 \\
29 \\
54\end{array}$ & $\begin{array}{l}81 \\
2.1 \\
26 \\
54\end{array}$ & & (NM) & (NM) & & (NM) & (NM) & & (NM) & \\
\hline
\end{tabular}




\begin{tabular}{|c|c|c|c|c|c|c|c|c|c|c|c|c|c|c|c|c|}
\hline & $\underbrace{5 / 18 / 1998 \cdot 5}$ & 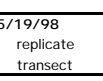 & $\left.\right|^{6 / 5 / 98-6 / 6 / 98}$ & $\begin{array}{l}8 \\
\text { repicicate } \\
\text { transect } \\
\end{array}$ & 6/29/1998 & $\begin{array}{l}\text { repicate } \\
\text { transect } \\
\end{array}$ & 7//20/1998 & $\begin{array}{l}\text { repicate } \\
\text { transect }\end{array}$ & $\left.\right|^{8 / 17 / 1998}$ & $\begin{array}{l}\text { repicicate repicicate repicicate } \\
\text { transect } \\
\text { transect } \\
\text { transect }\end{array}$ & $9^{9 / 4 / 1998}$ & $\begin{array}{l}\begin{array}{c}\text { repicate } \\
\text { transect }\end{array} \\
\text { the }\end{array}$ & $\left.\right|^{10 / 6 / / 98-10 / 7 / 98}$ & $\mid 11 / 7 / 1998$ & $\begin{array}{l}\begin{array}{c}\text { repicate } \\
\text { transect }\end{array} \\
\text { to }\end{array}$ & \begin{tabular}{|l}
$12 / 5 / 1998$ \\
\end{tabular} \\
\hline 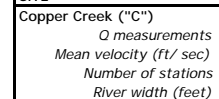 & \begin{tabular}{|l|}
106 \\
2.59 \\
199 \\
3.5
\end{tabular} & $\begin{array}{l}10,2 \\
2.61 \\
17 \\
35\end{array}$ & $\begin{array}{l}103 \\
2.5 \\
20 \\
36 \\
36\end{array}$ & $\begin{array}{l}109 \\
2.84 \\
20.5 \\
32.5\end{array}$ & & & 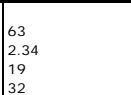 & $\begin{array}{l}60 \\
1.98 \\
20 \\
34\end{array}$ & (NM) & & (NM) & & (NM) & $(\mathrm{MM})$ & & (NM) \\
\hline 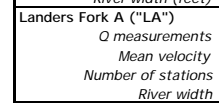 & $\begin{array}{l}129 \\
2.99 \\
199 \\
44\end{array}$ & $\begin{array}{l}149 \\
2.99 \\
21 \\
44\end{array}$ & $\begin{array}{l}135 \\
3.11 \\
201 \\
34.5\end{array}$ & & & & $\begin{array}{l}64 \\
1.74 \\
20 \\
39 \\
39\end{array}$ & & (NM) & & est. 10 cts & & (NM) & $(\mathrm{NM})$ & & (NM) \\
\hline 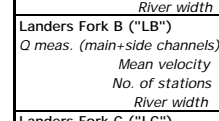 & 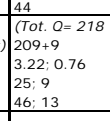 & 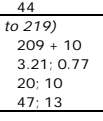 & 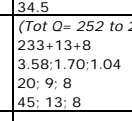 & 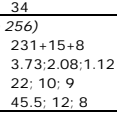 & 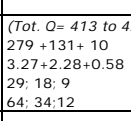 & 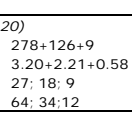 & 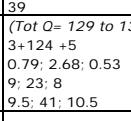 & 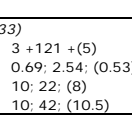 & $($ (NM) & & $\begin{array}{l}24+2 \\
1.08 \\
22 \\
34\end{array}$ & $\begin{array}{l}22+2 \\
0.95 ; 0.53 \\
20 ; 8 \\
34.5 ; 10 \\
\end{array}$ & $\begin{array}{l}17 \\
1.33 \\
17 \\
21 \\
21\end{array}$ & $\begin{array}{l}5 \\
8.36 \\
13 \\
15 \\
\end{array}$ & & (NM) \\
\hline 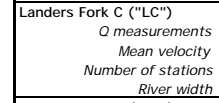 & \begin{tabular}{|l|}
286 \\
3.3.7 \\
307 \\
87
\end{tabular} & $\begin{array}{l}284 \\
3.09 \\
87 \\
87\end{array}$ & \begin{tabular}{|l}
292 \\
3.05 \\
31 \\
89 \\
\end{tabular} & $\begin{array}{l}309 \\
3.27 \\
32 \\
85\end{array}$ & $\begin{array}{l}54 \\
4.89 \\
21 \\
21 \\
61\end{array}$ & & $\begin{array}{l}128 \\
2.51 \\
35 \\
67 \\
67\end{array}$ & & (NM) & & & $\begin{array}{l}57.10 \\
17.99 \\
20 \\
26\end{array}$ & $\mid \begin{array}{l}42 \\
1.52 \\
20 \\
34\end{array}$ & $\begin{array}{l}32 \\
1.3 \\
20 \\
31\end{array}$ & & $\begin{array}{l}27.18 \\
1.18 \\
12\end{array}$ \\
\hline 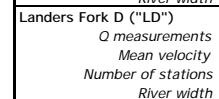 & (NM) & & (NM) & & $(\mathrm{NM})$ & & $\mid \begin{array}{l}135 \\
2.53 \\
22 \\
43\end{array}$ & $\begin{array}{l}135 \\
2.56 \\
23 \\
44\end{array}$ & $\mid \begin{array}{l}72 \\
2.08 \\
22 \\
23\end{array}$ & & (NM) & & (NM) & (NM) & & (NM) \\
\hline 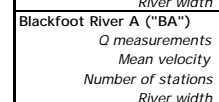 & (NM) & & (NM) & & $(\mathrm{NM})$ & & (NM) & & (NM) & & (NM) & & (NM) & $(\mathrm{NM})$ & & (NM) \\
\hline 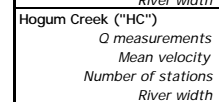 & $\begin{array}{l}8 \\
1.76 \\
7 \\
7\end{array}$ & $\begin{array}{l}8 \\
1.64 \\
6 \\
7\end{array}$ & $\begin{array}{l}14 \\
2.29 \\
11 \\
7\end{array}$ & $\begin{array}{l}15 \\
2.36 \\
8 \\
7\end{array}$ & (NM) & & 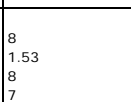 & & $\mid \begin{array}{l}2 \\
0.63 \\
10.6 \\
7.6\end{array}$ & $\begin{array}{lll}2 & 3 & 3 \\
1.2 & 0.67 & 1 \\
9 & 10 & 10 \\
7.5 & 7.5 & 7.5\end{array}$ & (NM) & & (NM) & (NM) & & (NM) \\
\hline 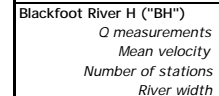 & $\begin{array}{l}56 \\
0.99 \\
17.5 \\
31.5\end{array}$ & $\begin{array}{l}55 \\
0.98 \\
14 \\
33.5\end{array}$ & $\begin{array}{l}85 \\
2.01 \\
24 \\
24.5\end{array}$ & $\begin{array}{l}86 \\
2.05 \\
22 \\
41\end{array}$ & (NM) & & $\begin{array}{l}71 \\
1.89 \\
24 \\
51\end{array}$ & & $\begin{array}{l}34 \\
1.12 \\
26 \\
38 \\
38\end{array}$ & $\begin{array}{l}32 \\
1.14 \\
24 \\
42\end{array}$ & (NM) & & (NM) & (NM) & & (NM) \\
\hline 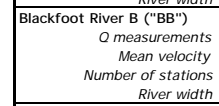 & $\begin{array}{l}64 \\
1.34 \\
20 \\
54 \\
54\end{array}$ & $\begin{array}{l}62 \\
1.3 \\
19 \\
54 \\
\end{array}$ & $\begin{array}{l}86 \\
1.8 \\
20 \\
31 \\
31\end{array}$ & $\begin{array}{l}87 \\
1.76 \\
20 \\
31\end{array}$ & $\begin{array}{l}218 \\
2.74 \\
1.74 \\
38\end{array}$ & $\begin{array}{l}213 \\
2.59 \\
139 \\
399\end{array}$ & 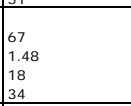 & & (NM) & & $\mid \begin{array}{l}19 \\
0.51 \\
20 \\
32\end{array}$ & $\begin{array}{l}20 \\
0.59 \\
20 \\
31\end{array}$ & $\begin{array}{l}221 \\
1.18 \\
21 \\
31\end{array}$ & $\begin{array}{l}11 \\
0.61 \\
15 \\
23\end{array}$ & & $\begin{array}{l}11 \\
0.38 \\
10 \\
40\end{array}$ \\
\hline 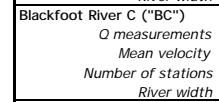 & $\mid \begin{array}{l}70 \\
1.59 \\
211 \\
41\end{array}$ & $\begin{array}{l}67 \\
1.57 \\
22 \\
41\end{array}$ & $\begin{array}{l}98 \\
2.02 \\
22 \\
43\end{array}$ & $\begin{array}{l}99 \\
1.99 \\
24 \\
43\end{array}$ & $\begin{array}{l}242 \\
3.2 \\
3.2 \\
48\end{array}$ & $\begin{array}{l}250 \\
3.22 \\
22 \\
46\end{array}$ & 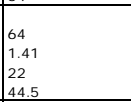 & & $\begin{array}{l}38 \\
1.15 \\
23 \\
43\end{array}$ & $\begin{array}{l}39 \\
1.22 \\
22.5 \\
43.5\end{array}$ & $\mid \begin{array}{l}27 \\
0.87 \\
221 \\
414\end{array}$ & $\begin{array}{l}25 \\
0.89 \\
20 \\
38\end{array}$ & $\mid \begin{array}{l}22 \\
0.92 \\
170 \\
20\end{array}$ & $\begin{array}{l}17 \\
0.72 \\
18 \\
36\end{array}$ & $\begin{array}{l}17 \\
0.76 \\
25 \\
39\end{array}$ & (NM) \\
\hline 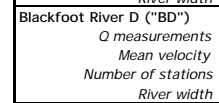 & (NM) & & (NM) & & (NM) & & (NM) & & $\begin{array}{l}129 \\
2.21 \\
27 \\
25.5\end{array}$ & & (NM) & & (NM) & (NM) & & (NM) \\
\hline
\end{tabular}




\begin{tabular}{|c|c|c|c|}
\hline \multicolumn{3}{|c|}{ Summary: pH meter calibration standard checks } & D.O. meter \\
\hline $\begin{array}{l}\text { Iotal number of } \\
\text { standard checks }\end{array}$ & $\begin{array}{r}7.00 \text { standard } \\
76\end{array}$ & $\begin{array}{c}10.00 \text { standard } \\
76\end{array}$ & $\begin{array}{l}\text { calibration slopes } \\
\text { mean slope }=88.43\end{array}$ \\
\hline Mean reading & 7.00 & 10.00 & stdev $=8.70$ \\
\hline Standard Deviation & 0.02 & 0.02 & \\
\hline Minimum reading & 6.96 & 9.93 & (reported acceptable \\
\hline Maximum reading & 7.09 & 10.09 & slope range: $70-120)$ \\
\hline
\end{tabular}

Table 3: Sample analysis dates

\begin{tabular}{|l|l|l|l|l|l|}
\hline $\begin{array}{l}\text { Sample } \\
\text { Date }\end{array}$ & $\begin{array}{l}\text { Ion Chromatography } \\
\text { Analysis date }\end{array}$ & $\begin{array}{l}\text { Inorganic Carbon } \\
\text { Analysis date }\end{array}$ & $\begin{array}{l}\text { Alkalinity } \\
\text { Analysis date }\end{array}$ & $\begin{array}{l}\text { Arsenic by AAS } \\
\text { Analysis date }\end{array}$ & $\begin{array}{l}\text { ICAPES } \\
\text { Analysis date }\end{array}$ \\
\hline $7 / 3 / 97,7 / 4 / 97$ & $7 / 6 / 1997$ & $7 / 9 / 1997$ & (Not analyzed) & $7 / 29 / 1997$ & $8 / 13 / 97-8 / 15 / 97$ \\
$7 / 20 / 97,7 / 21 / 97$ & $7 / 22 / 1997$ & $7 / 22 / 1997$ & (Not analyzed) & $7 / 29 / 1997$ & $8 / 13 / 97-8 / 15 / 97$ \\
$8 / 7 / 97,8 / 8 / 97$ & $8 / 9 / 1997$ & $8 / 13 / 1997$ & (Not analyzed) & $8 / 14 / 1997$ & $8 / 13 / 97-8 / 15 / 97$ \\
$9 / 13 / 97,9 / 14 / 97$ & $9 / 15 / 97-9 / 16 / 97$ & $9 / 15 / 97-9 / 16 / 97$ & (Not analyzed) & $10 / 31 / 1997$ & $10 / 23 / 1997$ \\
$10 / 19 / 1997$ & $10 / 20 / 1997$ & $10 / 20 / 1997$ & (Not analyzed) & $10 / 31 / 1997$ & $10 / 23 / 1997$ \\
$10 / 25 / 1997$ & $10 / 26 / 1997$ & $10 / 27 / 1997$ & (Not analyzed) & $10 / 31 / 1997$ & $10 / 30 / 1997$ \\
$11 / 16 / 1997$ & $11 / 18 / 1997$ & $11 / 17 / 1997$ & (Not analyzed) & $12 / 30 / 1997$ & $12 / 31 / 1997$ \\
$11 / 18 / 1997$ & $11 / 20 / 1997$ & $11 / 20 / 1997$ & (Not analyzed) & $12 / 30 / 1997$ & $12 / 31 / 1997$ \\
$1 / 6 / 1998$ & $1 / 8 / 1998$ & $1 / 7 / 1998$ & (Not analyzed) & $1 / 12 / 1998$ & $1 / 14 / 1998$ \\
$3 / 8 / 1998$ & (Not analyzed) & $3 / 18 / 1998$ & (Not analyzed) & $6 / 15 / 1998$ & $6 / 23 / 1998$ \\
$4 / 7 / 1998$ & (Not analyzed) & $4 / 8 / 1998$ & (Not analyzed) & $6 / 15 / 1998-6 / 18 / 98$ & $6 / 30 / 98,7 / 10 / 98$ \\
$4 / 26 / 1998$ & (Not analyzed) & $4 / 27 / 1998$ & (Not analyzed) & $6 / 15 / 1998-6 / 17 / 98$ & $6 / 30 / 98,7 / 10 / 98$ \\
$4 / 29 / 1998$ & (Not analyzed) & $4 / 30 / 1998$ & Not analyzed) & $6 / 15 / 1998-6 / 17 / 98$ & $6 / 30 / 98,7 / 10 / 98$ \\
$5 / 18 / 98,5 / 19 / 98$ & (Not analyzed) & $5 / 21 / 1998$ & (Not analyzed) & $6 / 18 / 1998$ & $7 / 6 / 98,7 / 13 / 98$ \\
$6 / 5 / 1998$ & (Not analyzed) & (Not analyzed) & $6 / 7 / 1998$ & $6 / 18 / 1998$ & $7 / 13 / 1998$ \\
$6 / 29 / 1998$ & (Not analyzed) & (Not analyzed) & $6 / 30 / 1998$ & $7 / 30 / 1998$ & $7 / 13 / 1998$ \\
$7 / 20 / 1998$ & (Not analyzed) & (Not analyzed) & $7 / 21 / 1998$ & $7 / 30 / 1998$ & $10 / 29 / 1998$ \\
$8 / 98$ basinwide & $8 / 18 / 1998$ & (Not analyzed) & $8 / 19 / 1998$ & $9 / 16 / 98-9 / 21 / 98$ & $1 / 13 / 99-1 / 16 / 99$ \\
$9 / 4 / 1998$ & (Not analyzed) & $9 / 9 / 1998$ & $9 / 9 / 1998$ & $9 / 14 / 1998$ & $1 / 17 / 1999$ \\
$10 / 6 / 1998$ & $10 / 7 / 1998$ & $10 / 7 / 1998$ & $10 / 7 / 1998$ & $11 / 11 / 1998$ & $1 / 17 / 1999$ \\
$11 / 7 / 1998$ & (Not analyzed) & (Not analyzed) & $11 / 9 / 1998$ & $3 / 1 / 1999$ & $1 / 18 / 1999$ \\
$12 / 5 / 1998$ & (Not analyzed) & $12 / 8 / 1998$ & $12 / 7 / 1998$ & $3 / 1 / 1999$ & $1 / 18 / 1999$ \\
\hline
\end{tabular}

Table 4:

Detection limits of analytes

\begin{tabular}{|c|c|}
\hline \multicolumn{2}{|c|}{ Practical Quantification } \\
\hline \multicolumn{2}{|c|}{ Limits (PQLs) } \\
\hline Analyte & PQL \\
\hline Inorganic carbor & $1 \mathrm{mg} / \mathrm{L}$ \\
\hline Organic carbon & $1 \mathrm{mg} / \mathrm{L}$ \\
\hline $\mathrm{F}$ & $0.05 \mathrm{mg} / \mathrm{L}$ \\
\hline $\mathrm{Cl}$ & $2 \mathrm{mg} / \mathrm{L}$ \\
\hline Nitrate-N & $0.2 \mathrm{mg} / \mathrm{L}$ \\
\hline Nitrite-N & $0.02 \mathrm{mg} / \mathrm{L}$ \\
\hline Phosphate-P & $0.2 \mathrm{mg} / \mathrm{L}$ \\
\hline Sulfate & $1.00 \mathrm{mg} / \mathrm{L}$ \\
\hline As & $0.2 \mu \mathrm{g} / \mathrm{L}$ \\
\hline $\mathrm{Ag}$ & $1 \mu \mathrm{g} / \mathrm{L}$ \\
\hline $\mathrm{Al}$ & $5 \mu \mathrm{g} / \mathrm{L}$ \\
\hline $\mathrm{Ba}$ & $1 \mu \mathrm{g} / \mathrm{L}$ \\
\hline $\mathrm{Be}$ & $0.05 \mu \mathrm{g} / \mathrm{L}$ \\
\hline $\mathrm{Ca}$ & $0.01 \mathrm{mg} / \mathrm{L}$ \\
\hline $\mathrm{Cd}$ & $0.5 \mu \mathrm{g} / \mathrm{L}$ \\
\hline Co & $0.5 \mu \mathrm{g} / \mathrm{L}$ \\
\hline $\mathrm{Cr}$ & $1 \mu \mathrm{g} / \mathrm{L}$ \\
\hline $\mathrm{Cu}$ & $0.8 \mu \mathrm{g} / \mathrm{L}$ \\
\hline $\mathrm{Fe}$ & $5 \mu \mathrm{g} / \mathrm{L}$ \\
\hline K & $0.10 \mathrm{mg} / \mathrm{L}$ \\
\hline $\mathrm{Li}$ & $0.5 \mu \mathrm{g} / \mathrm{L}$ \\
\hline Mg & $0.01 \mathrm{mg} / \mathrm{L}$ \\
\hline$M n$ & $0.3 \mu \mathrm{g} / \mathrm{L}$ \\
\hline Mo & $1 \mu \mathrm{g} / \mathrm{L}$ \\
\hline $\mathrm{Na}$ & $0.15 \mathrm{mg} / \mathrm{L}$ \\
\hline $\mathrm{Ni}$ & $2 \mu \mathrm{g} / \mathrm{L}$ \\
\hline $\mathrm{Pb}$ & $6 \mu \mathrm{g} / \mathrm{L}$ \\
\hline$S$ & $0.01 \mathrm{mg} / \mathrm{L}$ \\
\hline $\mathrm{Si}$ & $0.02 \mathrm{mg} / \mathrm{L}$ \\
\hline $\mathrm{Sr}$ & $2 \mu \mathrm{g} / \mathrm{L}$ \\
\hline $\mathrm{Ti}$ & $2 \mu \mathrm{g} / \mathrm{L}$ \\
\hline V & $2 \mu \mathrm{g} / \mathrm{L}$ \\
\hline $\mathrm{Zn}$ & $0.3 \mu \mathrm{g} / \mathrm{L}$ \\
\hline
\end{tabular}


Tables 5.1-5.3

External and Internal Standards Measurements

Table 5.1

\begin{tabular}{|lccc|}
\hline $\begin{array}{l}\text { Summary: External standards measured on AAS } \\
\text { Concentrations in } \mu \mathrm{g} / \mathrm{L} .\end{array}$ & $\begin{array}{c}\text { Reported } \\
\text { value (Range)* }\end{array}$ & $\begin{array}{c}\text { Measured values or } \\
\text { mean (std. dev.) }\end{array}$ & $\begin{array}{r}\text { Measured values } \\
\text { within Report. Range? }\end{array}$ \\
Standard & $10.8(4.2)$ & 9.4 & Yes \\
\hline USGS T-107 $(\mathrm{n}=1)$ & $4.2(0.57)$ & $4.0(0.5)$ & Yes \\
USGS T-119 $(\mathrm{n}=3)$ & $8(2.2)$ & $8.0,8.0$ & Yes \\
USGS T-121 $(\mathrm{n}=2)$ & $15.2(2.4)$ & $15.3(1.5)$ & Yes \\
USGS T-143 $(n=16)$ & $9.88(2.08)$ & $9.2(1.1)$ & Yes \\
USGS T-145 $(n=9)$ & $23.8(3.0)$ & $24.8(0.7)$ & Yes \\
USGS T-113 $(n=16)$ & &
\end{tabular}

*Reported Range is 2 pseudosigmas from the mean

Note: USGS Standards T-121, T-143, and T-113 were diluted to $10 \%$, and USGS Standards T107, T-119, and T-145 were diluted by $50 \%$ for analysis in order to fall within the range of calibration of the AAS.

Table 5.2

Summary: External standard "QC SPEX" measured on IC

(Concentrations in $\mathrm{mg} / \mathrm{L}$ )

\begin{tabular}{|lccc|} 
Analyte & $\begin{array}{l}\text { Reported } \\
\text { Mean (Range)* }\end{array}$ & $\begin{array}{c}\text { Measured } \\
\text { Mean (Stand. Dev.) }\end{array}$ & $\begin{array}{c}\text { Measured Mean } \\
\text { w/ in Reported Range? }\end{array}$ \\
\hline Fluoride $(n=10)$ & $3.0(0.47)$ & $2.8(0.1)$ & Yes \\
Chloride $(n=8)$ & $30.0(2.62)$ & $28.8(1.0)$ & Yes \\
Nitrate- $(n=10)$ & $5.0(0.84)$ & $4.9(0.2)$ & Yes \\
Nitrite-N $(n=10)$ & $2.0(0.21)$ & $1.9(0.1)$ & Yes \\
Phosphate- $P(n=10)$ & $1.0(0.29)$ & $1.0(0.1)$ & Yes \\
Sulfate $(n=10)$ & $30.0(5.27)$ & $29.6(2.2)$ & Yes \\
\hline
\end{tabular}

*Reported Range is the $95 \%$ Confidence Interval

Table 5.3

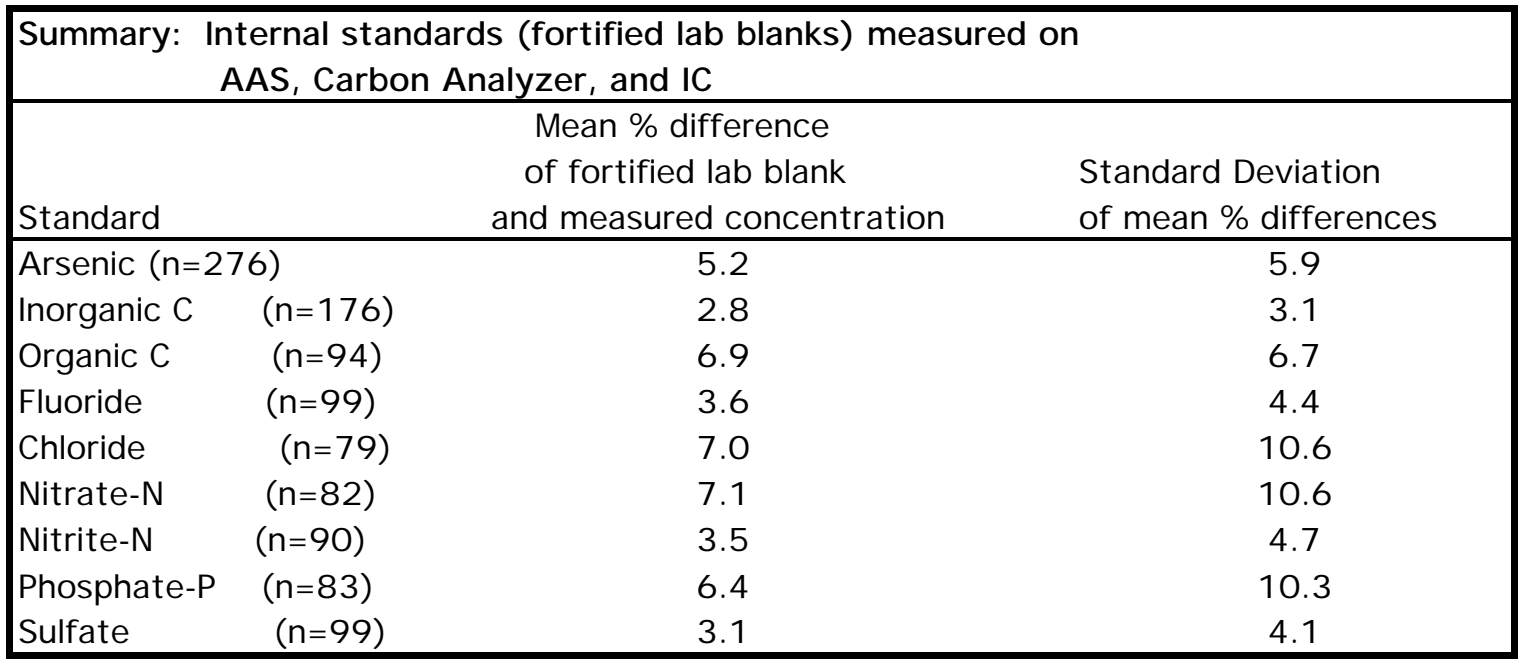


Tables 6.1-6.3: Summary of USGS standards measured on ICAPES during sample analyses.

Table 6.1

\begin{tabular}{|c|c|c|c|c|}
\hline \multicolumn{5}{|c|}{\begin{tabular}{|l|} 
Summary: USGS Standard T-107 measured on ICAPES \\
$(n=30)$
\end{tabular}} \\
\hline Element & Units & $\begin{array}{c}\text { Reported } \\
\text { Mean (Range)** }\end{array}$ & $\begin{array}{c}\text { Measured } \\
\text { Mean (Std. Dev.) }\end{array}$ & $\begin{array}{l}\text { Measured Mean } \\
\text { w/in Reported Range? }\end{array}$ \\
\hline $\mathrm{Ag}$ & $\mu \mathrm{g} / \mathrm{L}$ & $12.3(4.4)$ & $13.4(0.9)$ & Yes \\
\hline $\mathrm{Al}$ & $\mu \mathrm{g} / \mathrm{L}$ & $220(90)$ & $203(6)$ & Yes \\
\hline Ba & $\mu \mathrm{g} / \mathrm{L}$ & $192(22)$ & $173(8)$ & Yes \\
\hline $\mathrm{Be}$ & $\mu \mathrm{g} / \mathrm{L}$ & $11(2.2)$ & $10.6(0.3)$ & Yes \\
\hline $\mathrm{Ca}$ & $\mathrm{mg} / \mathrm{L}$ & $11.7(1.4)$ & $10.45(0.41)$ & Yes \\
\hline $\mathrm{Cd}$ & $\mu \mathrm{g} / \mathrm{L}$ & $14.3(4.2)$ & $12.4(0.5)$ & Yes \\
\hline co & $\mu \mathrm{g} / \mathrm{L}$ & $11(2.8)$ & $10.4(0.8)$ & Yes \\
\hline $\mathrm{Cr}$ & $\mu \mathrm{g} / \mathrm{L}$ & $13(4.2)$ & $11.0(0.5)$ & Yes \\
\hline $\mathrm{Cu}$ & $\mu \mathrm{g} / \mathrm{L}$ & $30(4.6)$ & $26.0(0.84)$ & Yes \\
\hline $\mathrm{Fe}$ & $\mu \mathrm{g} / \mathrm{L}$ & $52(14)$ & $54(4)$ & Yes \\
\hline K & $\mathrm{mg} / \mathrm{L}$ & $0.84(0.3)$ & $0.74(0.02)$ & Yes \\
\hline $\mathrm{Li}$ & $\mu \mathrm{g} / \mathrm{L}$ & $193(28)$ & $193.6(3.8)$ & Yes \\
\hline $\mathrm{Mg}$ & $\mathrm{mg} / \mathrm{L}$ & $2.1(0.26)$ & $1.95(0.05)$ & Yes \\
\hline Mn & $\mu \mathrm{g} / \mathrm{L}$ & 45 (12) & $40.7(1.3)$ & Yes \\
\hline Mo & $\mu \mathrm{g} / \mathrm{L}$ & $15(3.8)$ & $12.1(0.5)$ & Yes \\
\hline $\mathrm{Na}$ & $\mathrm{mg} / \mathrm{L}$ & $20.7(2.2)$ & $20.54(0.49)$ & Yes \\
\hline $\mathrm{Ni}$ & $\mu \mathrm{g} / \mathrm{L}$ & $28.1(7.8)$ & $23(1)$ & Yes \\
\hline $\mathrm{Pb}$ & $\mu \mathrm{g} / \mathrm{L}$ & $26(8)$ & 25 (1) & Yes \\
\hline $\mathrm{s}$ & $\mathrm{mg} / \mathrm{L}$ & (Not reported) & - & 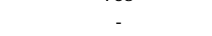 \\
\hline $\mathrm{Si}$ & $\mathrm{mg} / \mathrm{L}$ & $3.6(0.468)$ & $3.27(0.22)$ & Yes \\
\hline Sr & $\mu \mathrm{g} / \mathrm{L}$ & $61(8)$ & $51(2)$ & No \\
\hline $\mathrm{Ti}$ & $\mu \mathrm{g} / \mathrm{L}$ & (Not reported) & & \\
\hline V & $\mu \mathrm{g} / \mathrm{L}$ & $14(5.6)$ & $13(1)$ & Yes \\
\hline $\mathrm{Zn}$ & $\mu \mathrm{g} / \mathrm{L}$ & $75.8(19.8)$ & $68.9(3.3)$ & Yes \\
\hline
\end{tabular}

\begin{tabular}{|c|c|c|c|c|}
\hline \multicolumn{5}{|c|}{$\begin{array}{l}\text { Summary: USGS Standard T-143 measured on ICAPES } \\
(n=78)\end{array}$} \\
\hline & Units & $\begin{array}{c}\text { Reported } \\
\text { Mean (Range)* }\end{array}$ & $\begin{array}{c}\text { Measured } \\
\text { Mean (Std. Dev.) }\end{array}$ & $\begin{array}{c}\text { Measured Mean } \\
\text { w/ in Reported Range? }\end{array}$ \\
\hline $\mathrm{Ag}$ & $\mu g / L$ & $19.6(2.8)$ & $25.4(3.7)$ & No \\
\hline $\mathrm{Al}$ & $\mu \mathrm{g} / \mathrm{L}$ & $22.1(16.6)$ & $21.8(2.3)$ & Yes \\
\hline $\mathrm{Ba}$ & $\mu \mathrm{g} / \mathrm{L}$ & $81.9(9)$ & $75.2(3.1)$ & Yes \\
\hline Be & $\mu \mathrm{g} / \mathrm{L}$ & $8.5(1.32)$ & $8.3(0.4)$ & Yes \\
\hline $\mathrm{Ca}$ & $\mathrm{mg} / \mathrm{L}$ & $53.7(4.4)$ & $53.6(2.7)$ & Yes \\
\hline $\mathrm{Cd}$ & $\mu \mathrm{g} / \mathrm{L}$ & $19.1(3)$ & $17.6(0.7)$ & Yes \\
\hline Co & $\mu g / L$ & $17(2.4)$ & $15.7(0.5)$ & Yes \\
\hline $\mathrm{Cr}$ & $\mu \mathrm{g} / \mathrm{L}$ & $37(5.2)$ & $33(1)$ & Yes \\
\hline $\mathrm{Cu}$ & $\mu \mathrm{g} / \mathrm{L}$ & $22.3(3.8)$ & $22.6(0.9)$ & Yes \\
\hline $\mathrm{Fe}$ & $\mu g / L$ & $222(28)$ & 225 (12) & Yes \\
\hline K & $\mathrm{mg} / \mathrm{L}$ & $2.5(0.42)$ & $2.5(0.11)$ & Yes \\
\hline $\mathrm{Li}$ & $\mu \mathrm{g} / \mathrm{L}$ & $18(4.2)$ & $17.6(0.8)$ & Yes \\
\hline $\mathrm{Mg}$ & $\mathrm{mg} / \mathrm{L}$ & $10.4(1)$ & $10.7(0.3)$ & Yes \\
\hline $\mathrm{Mn}$ & $\mu \mathrm{g} / \mathrm{L}$ & $18.2(3.8)$ & $16.5(0.5)$ & Yes \\
\hline Mo & $\mu \mathrm{g} / \mathrm{L}$ & $36.1(8.6)$ & 32.5 (1.4) & Yes \\
\hline $\mathrm{Na}$ & $\mathrm{mg} / \mathrm{L}$ & $34(3.2)$ & $35.0(1.2)$ & Yes \\
\hline $\mathrm{Ni}$ & $\mu \mathrm{g} / \mathrm{L}$ & $71(10)$ & $64.1(3.2)$ & Yes \\
\hline $\mathrm{Pb}$ & $\mu \mathrm{g} / \mathrm{L}$ & $83.4(14.2)$ & $82.9(2.9)$ & Yes \\
\hline s & $\mathrm{mg} / \mathrm{L}$ & (Not reported) & & . \\
\hline $\mathrm{Si}$ & $\mathrm{mg} / \mathrm{L}$ & $10.94(1.64)$ & $11.54(0.58)$ & Yes \\
\hline $\mathrm{Sr}$ & $\mu \mathrm{g} / \mathrm{L}$ & $306(30)$ & $270(12)$ & No \\
\hline $\mathrm{Ti}$ & $\mu \mathrm{g} / \mathrm{L}$ & (Not reported) & & \\
\hline v & $\mu \mathrm{g} / \mathrm{L}$ & $30(6)$ & $28.5(2.2)$ & Yes \\
\hline $\mathrm{Zn}$ & $\mu \mathrm{g} / \mathrm{L}$ & $20(4.4)$ & $18.3(0.9)$ & Yes \\
\hline
\end{tabular}

$\begin{array}{rrr}\mu \mathrm{g} / \mathrm{L} & 20(4.4) & 18.3(0.9) \\ \text { *Reported Range is } 2 \text { pseudosigmas from the mean }\end{array}$
Table 6.3

\begin{tabular}{|c|c|c|c|c|}
\hline \multicolumn{5}{|c|}{\begin{tabular}{|l|} 
Summary: USGS Standard T-145 measured on ICAPES \\
$(n=42)$
\end{tabular}} \\
\hline Element & Units & $\begin{array}{c}\text { Reported } \\
\text { Mean (Range)* }\end{array}$ & $\begin{array}{c}\text { Measured } \\
\text { Mean (Std. Dev) }\end{array}$ & $\begin{array}{l}\text { Measured Mean } \\
\text { w/in Reported Range? }\end{array}$ \\
\hline $\mathrm{Ag}$ & $\mu \mathrm{g} / \mathrm{L}$ & $7.55(1.84)$ & $8.8(1.4)$ & Yes \\
\hline $\mathrm{Al}$ & $\mu \mathrm{g} / \mathrm{L}$ & $67.6(22)$ & $66.9(6.6)$ & Yes \\
\hline Ba & $\mu \mathrm{g} / \mathrm{L}$ & $37.1(3.8)$ & $34.9(1.78)$ & Yes \\
\hline $\mathrm{Be}$ & $\mu \mathrm{g} / \mathrm{L}$ & $9.04(1.4)$ & $8.7(0.4)$ & Yes \\
\hline $\mathrm{Ca}$ & $\mathrm{mg} / \mathrm{L}$ & $30.7(2.6)$ & $29.6(1.6)$ & Yes \\
\hline $\mathrm{Cd}$ & $\mu \mathrm{g} / \mathrm{L}$ & $9.33(1.64)$ & $8.6(0.4)$ & Yes \\
\hline Co & $\mu \mathrm{g} / \mathrm{L}$ & $10(1.8)$ & $9.3(0.4)$ & Yes \\
\hline $\mathrm{Cr}$ & $\mu \mathrm{g} / \mathrm{L}$ & $15.3(2.8)$ & $13.3(0.7)$ & Yes \\
\hline $\mathrm{Cu}$ & $\mu \mathrm{g} / \mathrm{L}$ & $11(2.8)$ & $10.9(0.4)$ & Yes \\
\hline $\mathrm{Fe}$ & $\mu \mathrm{g} / \mathrm{L}$ & $101(16)$ & $102(7)$ & Yes \\
\hline K & $\mathrm{mg} / \mathrm{L}$ & $2.13(0.32)$ & $2.05(0.08)$ & Yes \\
\hline $\mathrm{Li}$ & $\mu \mathrm{g} / \mathrm{L}$ & $27.3(5)$ & $25.9(1.7)$ & Yes \\
\hline $\mathrm{Mg}$ & $\mathrm{mg} / \mathrm{L}$ & $8.68(0.9)$ & $8.52(0.28)$ & Yes \\
\hline $\mathrm{Mn}$ & $\mu \mathrm{g} / \mathrm{L}$ & $20.9(3)$ & $19.2(0.8)$ & Yes \\
\hline Mo & $\mu \mathrm{g} / \mathrm{L}$ & $9.23(2.58)$ & $7.9(0.5)$ & Yes \\
\hline $\mathrm{Na}$ & $\mathrm{mg} / \mathrm{L}$ & $41.2(3.8)$ & $42.4(2.4)$ & Yes \\
\hline $\mathrm{Ni}$ & $\mu \mathrm{g} / \mathrm{L}$ & $11(2.6)$ & $9.5(0.7)$ & Yes \\
\hline $\mathrm{Pb}$ & $\mu \mathrm{g} / \mathrm{L}$ & $12.7(2.4)$ & $12.3(0.7)$ & Yes \\
\hline $\mathrm{s}$ & $\mathrm{mg} / \mathrm{L}$ & (Not reported) & 10 & res \\
\hline $\mathrm{Si}$ & $\mathrm{mg} / \mathrm{L}$ & $5.28(0.66)$ & $5.82(0.25)$ & Yes \\
\hline $\mathrm{Sr}$ & $\mu \mathrm{g} / \mathrm{L}$ & $203(18)$ & $178(7)$ & No \\
\hline $\mathrm{Ti}$ & $\mu \mathrm{g} / \mathrm{L}$ & (Not reported) & & \\
\hline v & $\mu \mathrm{g} / \mathrm{L}$ & $11.7(3.4)$ & $10.3(0.7)$ & Yes \\
\hline Zn & $\mu \mathrm{g} / \mathrm{L}$ & $10(4.8)$ & $8.9(0.6)$ & Yes \\
\hline
\end{tabular}


Tables 7.1-7.4: Duplicates and Spike Recoveries

Table 7.1

\begin{tabular}{cccc|}
\hline \multicolumn{5}{c}{ Summary: ICAPES duplicate comparisons of water samples } \\
\hline Element & $\begin{array}{c}\text { Number of } \\
\text { dupl. pairs } \\
\text { above PQL }\end{array}$ & $\begin{array}{c}\text { Mean \% difference } \\
\text { of dupl. pairs }\end{array}$ & $\begin{array}{c}\text { Stand. dev. of mean difference } \\
\text { of dupl. pairs }\end{array}$ \\
\hline $\mathrm{Ag}$ & 0 & - & - \\
$\mathrm{Al}$ & 0 & - & - \\
$\mathrm{Ba}$ & 55 & 3.8 & 4.0 \\
$\mathrm{Be}$ & 0 & - & - \\
$\mathrm{Ca}$ & 55 & 3.6 & 4.7 \\
$\mathrm{Cd}$ & 0 & - & - \\
$\mathrm{Co}$ & 0 & - & - \\
$\mathrm{Cr}$ & 12 & 7.4 & 4.2 \\
$\mathrm{Cu}$ & 13 & 3.3 & 4.0 \\
$\mathrm{Fe}$ & 36 & 7.8 & 10.0 \\
$\mathrm{~K}$ & 54 & 4.1 & 5.0 \\
$\mathrm{Li}$ & 55 & 3.4 & 4.3 \\
$\mathrm{Mg}$ & 55 & 2.9 & 4.3 \\
$\mathrm{Mn}$ & 31 & 3.8 & 4.8 \\
$\mathrm{Mo}$ & 0 & - & - \\
$\mathrm{Na}$ & 55 & 5.4 & 6.7 \\
$\mathrm{Ni}$ & 0 & - & - \\
$\mathrm{Pb}$ & 0 & - & - \\
$\mathrm{S}$ & 55 & 5.0 & 6.7 \\
$\mathrm{Si}$ & 55 & 3.3 & 4.4 \\
$\mathrm{Sr}$ & 55 & 4.0 & 5.2 \\
$\mathrm{Ti}$ & 0 & - & - \\
$\mathrm{V}$ & 0 & 7.8 & \\
$\mathrm{Zn}$ & 28 & & -3 \\
& & & \\
\hline
\end{tabular}

Table 7.2

\begin{tabular}{|lccc|}
\hline \multicolumn{4}{|c|}{$\begin{array}{c}\text { Summary: } \\
\text { CAS, Carbon Analyzer, and IC Replicate } \\
\text { Comparisons }\end{array}$} \\
\hline $\begin{array}{c}\text { Number of } \\
\text { Analyte }\end{array}$ & $\begin{array}{c}\text { Mean \% difference } \\
\text { replicate sets } \\
\text { above PQL }\end{array}$ & $\begin{array}{c}\text { Stand. dev. Of mean of } \\
\text { replicate sets }\end{array}$ & $\begin{array}{c}\text { of \% diff./ \%RSD } \\
\text { of replicate pairs }\end{array}$ \\
\hline Arsenic $=<0.5 \mathrm{ppb}$ & 63 & 7.0 & 6.1 \\
Arsenic $>0.5 \mathrm{ppb}$ & 39 & 3.6 & 3.5 \\
Alkalinity & 27 & 3.2 & 3.4 \\
Inorganic C & 71 & 2.0 & 2.7 \\
Organic C & 35 & 9.1 & 11.2 \\
Fluoride & 58 & 3.5 & 1.5 \\
Chloride & 0 & - & - \\
Nitrate-N & 0 & - & - \\
Nitrite-N & 0 & - & - \\
Phosphate-P & 0 & - & 2.1 \\
Sulfate & 69 & 1.5 & - \\
\hline
\end{tabular}

Table 7.3

\begin{tabular}{|c|c|c|c|c|c|}
\hline Element & Unit & $\begin{array}{l}\text { Spike } \\
\text { values }\end{array}$ & $\begin{array}{l}\text { Number } \\
\text { of samples } \\
\text { above PQL }\end{array}$ & $\begin{array}{l}\text { Mean percent } \\
\text { recovery }\end{array}$ & $\begin{array}{l}\text { Stand. dev. of } \\
\text { mean percent } \\
\text { recovery }\end{array}$ \\
\hline $\mathrm{Ag}$ & $\mu g / L$ & 20 & 0 & - & - \\
\hline $\mathrm{Al}$ & $\mu \mathrm{g} / \mathrm{L}$ & 10 & 0 & - & - \\
\hline $\mathrm{Ba}$ & $\mu \mathrm{g} / \mathrm{L}$ & 200 & 58 & 98.0 & 9.5 \\
\hline $\mathrm{Be}$ & $\mu g / L$ & - & 0 & - & - \\
\hline $\mathrm{Ca}$ & $\mathrm{mg} / \mathrm{L}$ & $10,20,30$ & 40 & 102.5 & 10.3 \\
\hline $\mathrm{Cd}$ & $\mu \mathrm{g} / \mathrm{L}$ & 10 & 0 & - & - \\
\hline Co & $\mu \mathrm{g} / \mathrm{L}$ & - & 0 & - & - \\
\hline $\mathrm{Cr}$ & $\mu \mathrm{g} / \mathrm{L}$ & 10 & 18 & 100.7 & 7.6 \\
\hline $\mathrm{Cu}$ & $\mu \mathrm{g} / \mathrm{L}$ & $3,10,20$ & 15 & 106.9 & 6.7 \\
\hline $\mathrm{Fe}$ & $\mu g / L$ & $20,30,50$ & 43 & 106.0 & 16.3 \\
\hline K & $\mathrm{mg} / \mathrm{L}$ & $1,2,2.5$ & 58 & 101.3 & 5.6 \\
\hline $\mathrm{Li}$ & $\mu \mathrm{g} / \mathrm{L}$ & 5,10 & 56 & 103.0 & 6.0 \\
\hline $\mathrm{Mg}$ & $\mathrm{mg} / \mathrm{L}$ & 5,10 & 59 & 103.8 & 6.4 \\
\hline $\mathrm{Mn}$ & $\mu \mathrm{g} / \mathrm{L}$ & 10 & 23 & 92.0 & 4.8 \\
\hline Mo & $\mu \mathrm{g} / \mathrm{L}$ & - & 0 & - & - \\
\hline $\mathrm{Na}$ & $\mathrm{mg} / \mathrm{L}$ & $2.5,5.10$ & 58 & 102.6 & 7.5 \\
\hline $\mathrm{Ni}$ & $\mu \mathrm{g} / \mathrm{L}$ & 20 & 0 & - & - \\
\hline $\mathrm{Pb}$ & $\mu g / L$ & 80 & 0 & - & - \\
\hline$S$ & $\mathrm{mg} / \mathrm{L}$ & 2,5 & 55 & 111.8 & 8.5 \\
\hline $\mathrm{Si}$ & $\mathrm{mg} / \mathrm{L}$ & 2,5 & 55 & 111.9 & 8.7 \\
\hline $\mathrm{Sr}$ & $\mu g / L$ & 50,100 & 54 & 92.5 & 8.6 \\
\hline $\mathrm{Ti}$ & $\mu \mathrm{g} / \mathrm{L}$ & - & 0 & - & - \\
\hline V & $\mu g / L$ & - & 0 & - & - \\
\hline $\mathrm{Zn}$ & $\mu \mathrm{g} / \mathrm{L}$ & 10,20 & 37 & 104.4 & 8.1 \\
\hline
\end{tabular}

Table 7.4

\begin{tabular}{|lccccc|}
\hline \multicolumn{7}{|c|}{$\begin{array}{c}\text { Summary: } \\
\text { recoveries }\end{array}$} & $\begin{array}{c}\text { AAS, Carbon Analyzer, and IC Spike (fortified sample) } \\
\text { Analyte }\end{array}$ & Unit & Value & $\begin{array}{c}\text { Number } \\
\text { of samples } \\
\text { above PQL }\end{array}$ & $\begin{array}{c}\text { Mean percent } \\
\text { recovery }\end{array}$ & $\begin{array}{c}\text { Stand. dev. of } \\
\text { mean percent } \\
\text { recovery }\end{array}$ \\
\hline Arsenic & $\mu \mathrm{g} / \mathrm{L}$ & 1.0 & 44 & 109.8 & 7.0 \\
Organic C & $\mathrm{mg} / \mathrm{L}$ & $0.5,2.0$ & 10 & 95.6 & 31.8 \\
Fluoride & $\mathrm{mg} / \mathrm{L}$ & 0.1 & 26 & 85.9 & 14.8 \\
Chloride & $\mathrm{mg} / \mathrm{L}$ & 0.2 & - & - & - \\
Nitrate-N & $\mathrm{mg} / \mathrm{L}$ & 0.025 & - & - & - \\
Nitrite-N & $\mathrm{mg} / \mathrm{L}$ & 0.025 & - & - & - \\
Phosphate-P & $\mathrm{mg} / \mathrm{L}$ & 0.025 & - & - & - \\
Sulfate & $\mathrm{mg} / \mathrm{L}$ & $0.5,1.5,3.0$ & 32 & 109.2 & 19.4 \\
\hline
\end{tabular}

$\mathrm{PQL}=$ Practical Quantifiable Limit

$\%$ RSD $=$ Percent relative standard deviation

Tables : Summary of duplicates and spike recoveries measured on all instruments used for analysis of water samples. 
Tables 8.1 - 8.4: Laboratory and Field Blanks

\begin{tabular}{|c|c|c|c|c|}
\hline \multicolumn{5}{|c|}{ Summary:ICAPES measurement of Lab Blanks } \\
\hline Element & Units & $\mathrm{PQL}$ & $\begin{array}{c}\text { Total } \\
\text { number } \\
\text { of blanks }\end{array}$ & $\begin{array}{c}\text { Number } \\
\text { of blanks } \\
\text { below PQL }\end{array}$ \\
\hline $\mathrm{Ag}$ & $\mu \mathrm{g} / \mathrm{L}$ & 1 & 41 & 41 \\
\hline Al & $\mu \mathrm{g} / \mathrm{L}$ & 5 & 41 & 41 \\
\hline $\mathrm{Ba}$ & $\mu \mathrm{g} / \mathrm{L}$ & 1 & 41 & 41 \\
\hline $\mathrm{Be}$ & $\mu \mathrm{g} / \mathrm{L}$ & 0.05 & 41 & 41 \\
\hline $\mathrm{Ca}$ & $\mathrm{mg} / \mathrm{L}$ & 0.01 & 41 & 41 \\
\hline $\mathrm{Cd}$ & $\mu g / L$ & 0.5 & 41 & 41 \\
\hline Co & $\mu \mathrm{g} / \mathrm{L}$ & 0.5 & 41 & 41 \\
\hline $\mathrm{Cr}$ & $\mu \mathrm{g} / \mathrm{L}$ & 1 & 41 & 41 \\
\hline $\mathrm{Cu}$ & $\mu \mathrm{g} / \mathrm{L}$ & 0.8 & 41 & 41 \\
\hline $\mathrm{Fe}$ & $\mu \mathrm{g} / \mathrm{L}$ & 5 & 41 & 41 \\
\hline $\mathrm{K}$ & $\mathrm{mg} / \mathrm{L}$ & 0.10 & 41 & 41 \\
\hline $\mathrm{Li}$ & $\mu \mathrm{g} / \mathrm{L}$ & 0.5 & 41 & 41 \\
\hline $\mathrm{Mg}$ & $\mathrm{mg} / \mathrm{L}$ & 0.01 & 41 & 41 \\
\hline $\mathrm{Mn}$ & $\mu \mathrm{g} / \mathrm{L}$ & 0.3 & 41 & 41 \\
\hline Mo & $\mu \mathrm{g} / \mathrm{L}$ & 1 & 41 & 41 \\
\hline $\mathrm{Na}$ & $\mathrm{mg} / \mathrm{L}$ & 0.15 & 41 & 41 \\
\hline $\mathrm{Ni}$ & $\mu \mathrm{g} / \mathrm{L}$ & 2 & 41 & 41 \\
\hline $\mathrm{Pb}$ & $\mu \mathrm{g} / \mathrm{L}$ & 6 & 41 & 41 \\
\hline S & $\mathrm{mg} / \mathrm{L}$ & 0.01 & 41 & 41 \\
\hline $\mathrm{Si}$ & $\mathrm{mg} / \mathrm{L}$ & 0.02 & 41 & 41 \\
\hline $\mathrm{Sr}$ & $\mu \mathrm{g} / \mathrm{L}$ & 2 & 41 & 41 \\
\hline $\mathrm{Ti}$ & $\mu \mathrm{g} / \mathrm{L}$ & 2 & 41 & 41 \\
\hline V & $\mu \mathrm{g} / \mathrm{L}$ & 2 & 41 & 41 \\
\hline $\mathrm{Zn}$ & $\mu \mathrm{g} / \mathrm{L}$ & 0.3 & 41 & 41 \\
\hline
\end{tabular}

\begin{tabular}{|c|c|c|c|c|c|}
\hline \multicolumn{6}{|c|}{ Summary: ICAPES measurement of Field Blanks } \\
\hline Element & Units & $\mathrm{PQL}$ & $\begin{array}{c}\text { Total } \\
\text { number } \\
\text { of blanks }\end{array}$ & $\begin{array}{c}\text { Number of } \\
\text { of blanks } \\
\text { below PQL }\end{array}$ & $\begin{array}{l}\text { Highest } \\
\text { Conc. } \\
\text { found }\end{array}$ \\
\hline $\mathrm{Ag}$ & $\mu g / L$ & 1 & 31 & 31 & BPQL \\
\hline $\mathrm{Al}$ & $\mu \mathrm{g} / \mathrm{L}$ & 5 & 31 & 31 & BPQL \\
\hline $\mathrm{Ba}$ & $\mu \mathrm{g} / \mathrm{L}$ & 1 & 31 & 31 & BPQL \\
\hline $\mathrm{Be}$ & $\mu \mathrm{g} / \mathrm{L}$ & 0.05 & 31 & 31 & BPQL \\
\hline $\mathrm{Ca}$ & $\mathrm{mg} / \mathrm{L}$ & 0.01 & 31 & 8 & 0.04 \\
\hline $\mathrm{Cd}$ & $\mu g / L$ & 0.5 & 31 & 31 & BPQL \\
\hline Co & $\mu g / L$ & 0.5 & 31 & 31 & BPQL \\
\hline $\mathrm{Cr}$ & $\mu g / L$ & 1 & 31 & 31 & BPQL \\
\hline $\mathrm{Cu}$ & $\mu \mathrm{g} / \mathrm{L}$ & 0.8 & 31 & 31 & BPQL \\
\hline $\mathrm{Fe}$ & $\mu \mathrm{g} / \mathrm{L}$ & 5 & 31 & 31 & BPQL \\
\hline K & $\mathrm{mg} / \mathrm{L}$ & 0.10 & 31 & 31 & BPQL \\
\hline $\mathrm{Li}$ & $\mu \mathrm{g} / \mathrm{L}$ & 0.5 & 31 & 31 & BPQL \\
\hline $\mathrm{Mg}$ & $\mathrm{mg} / \mathrm{L}$ & 0.01 & 31 & 19 & 0.02 \\
\hline $\mathrm{Mn}$ & $\mu \mathrm{g} / \mathrm{L}$ & 0.3 & 31 & 31 & BPQL \\
\hline Mo & $\mu \mathrm{g} / \mathrm{L}$ & 1 & 31 & 31 & BPQL \\
\hline $\mathrm{Na}$ & $\mathrm{mg} / \mathrm{L}$ & 0.15 & 31 & 20 & 0.42 \\
\hline $\mathrm{Ni}$ & $\mu \mathrm{g} / \mathrm{L}$ & 2 & 31 & 31 & BPQL \\
\hline $\mathrm{Pb}$ & $\mu \mathrm{g} / \mathrm{L}$ & 6 & 31 & 31 & BPQL \\
\hline$S$ & $\mathrm{mg} / \mathrm{L}$ & 0.01 & 31 & 25 & 0.04 \\
\hline $\mathrm{Si}$ & $\mathrm{mg} / \mathrm{L}$ & 0.02 & 31 & 29 & 0.03 \\
\hline $\mathrm{Sr}$ & $\mu \mathrm{g} / \mathrm{L}$ & 2 & 31 & 31 & BPQL \\
\hline $\mathrm{Ti}$ & $\mu \mathrm{g} / \mathrm{L}$ & 2 & 31 & 31 & BPQL \\
\hline V & $\mu g / L$ & 2 & 31 & 31 & BPQL \\
\hline $\mathrm{Zn}$ & $\mu \mathrm{g} / \mathrm{L}$ & 0.3 & 31 & 24 & 3.7 \\
\hline
\end{tabular}

PQL = Practical Quantifiable Limit

BPQL= Below Practical Quantifiable Limit

Table 8.3

Summary: Laboratory blanks measured on AAS, Carbon Analyzer, and IC

\begin{tabular}{|lcc|cc|}
\hline Analyte & Units & PQL & $\begin{array}{c}\text { Total } \\
\text { number } \\
\text { of blanks }\end{array}$ & $\begin{array}{c}\text { Number } \\
\text { of blanks } \\
\text { BPQL }\end{array}$ \\
\hline Arsenic & $\mu \mathrm{g} / \mathrm{L}$ & 0.3 & 95 & 95 \\
Inorganic C & $\mathrm{mg} / \mathrm{L}$ & 1.0 & 50 & 50 \\
Organic C & $\mathrm{mg} / \mathrm{L}$ & 1.0 & 40 & 40 \\
Fluoride & $\mathrm{mg} / \mathrm{L}$ & 0.05 & 27 & 27 \\
Chloride & $\mathrm{mg} / \mathrm{L}$ & 2 & 27 & 27 \\
Nitrate-N & $\mathrm{mg} / \mathrm{L}$ & 0.2 & 27 & 27 \\
Nitrite-N & $\mathrm{mg} / \mathrm{L}$ & 0.02 & 27 & 27 \\
Phosphate-P & $\mathrm{mg} / \mathrm{L}$ & 0.2 & 27 & 27 \\
Sulfate & $\mathrm{mg} / \mathrm{L}$ & 1.00 & 27 & 27 \\
\hline
\end{tabular}

Table 8.4

Summary: Field Blanks measured on AAS, Carbon Analyzer, and IC

\begin{tabular}{|c|c|c|c|c|}
\hline Analyte & Units & $\mathrm{PQL}$ & $\begin{array}{c}\text { Total } \\
\text { number } \\
\text { of blanks }\end{array}$ & $\begin{array}{c}\text { Number } \\
\text { of blanks } \\
\text { BPQL }\end{array}$ \\
\hline Arsenic & $\mu \mathrm{g} / \mathrm{L}$ & 0.3 & 28 & 28 \\
\hline Alkalinity & $\mathrm{mg} / \mathrm{L}$ & 1 & 8 & 8 \\
\hline Inorganic C & $\mathrm{mg} / \mathrm{L}$ & 1.0 & 28 & 28 \\
\hline Organic C & $\mathrm{mg} / \mathrm{L}$ & 1.0 & 19 & 19 \\
\hline Fluoride & $\mathrm{mg} / \mathrm{L}$ & 0.05 & 15 & 15 \\
\hline Chloride & $\mathrm{mg} / \mathrm{L}$ & 2 & 15 & 15 \\
\hline Nitrate-N & $\mathrm{mg} / \mathrm{L}$ & 0.2 & 15 & 15 \\
\hline Nitrite-N & $\mathrm{mg} / \mathrm{L}$ & 0.02 & 15 & 15 \\
\hline Phosphate-P & $\mathrm{mg} / \mathrm{L}$ & 0.2 & 15 & 15 \\
\hline Sulfate & $\mathrm{mg} / \mathrm{L}$ & 1.00 & 15 & 15 \\
\hline
\end{tabular}


Table 9: All data for water samples collected April 1998-December 1998

All elements BPQL for: Al $(<5), \mathrm{Cd},(<0.5)$, $\mathrm{Co}(<0.5), \mathrm{Ni}(<2), \mathrm{Pb}(<6), \mathrm{Ti}(<2)$, and $\mathrm{V}(<2)($ in $\mu \mathrm{g} / \mathrm{L})$

\begin{tabular}{|c|c|c|c|c|c|c|c|c|c|c|c|c|c|c|c|c|c|c|c|c|c|c|c|c|c|c|}
\hline \begin{tabular}{|l} 
SAMPLE \\
NAME
\end{tabular} & $\begin{array}{l}\text { SAMPLE } \\
\text { DATE }\end{array}$ & $\begin{array}{l}\text { STREAM- } \\
\text { FLOW } \\
\text { (cfs) }\end{array}$ & $\begin{array}{l}\text { STREAM- } \\
\text { FLOW } \\
(\mathrm{L} / \mathrm{s}) \\
\end{array}$ & $\begin{array}{l}\mathrm{pH} \\
\text { (units) } \\
\end{array}$ & $\begin{array}{l}\text { D.O. } \\
(\mathrm{mg} / \mathrm{L})\end{array}$ & $\begin{array}{l}\text { Con- } \\
\text { ductivity } \\
(\mathrm{mS} / \mathrm{cm}) \\
\end{array}$ & $\begin{array}{l}\text { Water } \\
\text { Temp } \\
\text { (Cel.) } \\
\end{array}$ & $\begin{array}{l}\text { Air } \\
\text { Temp } \\
\text { (Cel.) } \\
\end{array}$ & $\begin{array}{l}\text { Inorganic } \\
\text { Carbon } \\
(\mathrm{mg} / \mathrm{L}) \\
\end{array}$ & $\begin{array}{l}\text { Total } \\
\text { Alkalinity } \\
\text { (mg/L CaC }\end{array}$ & $\begin{array}{l}\text { Sulfate } \\
\left.\mathrm{CO}_{3}\right) \\
\end{array}$ & $\begin{array}{l}\text { As } \\
(\mu \mathrm{g} / \mathrm{L}) \\
\end{array}$ & $\begin{array}{l}\text { Ba } \\
(\mu \mathrm{g} / \mathrm{L}) \\
\end{array}$ & $\begin{array}{l}\mathrm{Ca} \\
(\mathrm{mg} / \mathrm{L}) \\
\end{array}$ & $\begin{array}{l}\mathrm{Cr} \\
(\mu \mathrm{g} / \mathrm{L}) \\
\end{array}$ & $\begin{array}{l}\mathrm{Cu} \\
(\mu \mathrm{g} / \mathrm{L}) \\
\end{array}$ & $\begin{array}{l}\mathrm{Fe} \\
(\mu \mathrm{g} / \mathrm{L}) \\
\end{array}$ & $\begin{array}{l}\mathrm{K} \\
(\mathrm{mg} / \mathrm{L})\end{array}$ & $\begin{array}{l}\mathrm{Li} \\
(\mu \mathrm{g} / \mathrm{L}) \\
\end{array}$ & $\begin{array}{l}\mathrm{Mg} \\
(\mathrm{mg} / \mathrm{L})\end{array}$ & $\begin{array}{l}\text { Mn } \\
(\mu \mathrm{g} / \mathrm{L}) \\
\end{array}$ & $\begin{array}{l}\mathrm{Na} \\
(\mathrm{mg} / \mathrm{L})\end{array}$ & $\begin{array}{l}\mathrm{S} \\
(\mathrm{mg} / \mathrm{L}) \\
\end{array}$ & $\begin{array}{l}\mathrm{Si} \\
(\mathrm{mg} / \mathrm{L}) \\
\end{array}$ & $\begin{array}{l}\mathrm{Sr} \\
(\mu \mathrm{g} / \mathrm{L})\end{array}$ & $\begin{array}{l}\mathrm{Zn} \\
(\mu \mathrm{g} / \mathrm{L}) \\
\end{array}$ \\
\hline \multicolumn{27}{|c|}{ Copper Creek } \\
\hline $\mathrm{C}-1$ & 4/7/1998 & 13.86 & 393 & 8.26 & NA & 0.21 & 2.7 & 6.0 & 27.8 & NA & NA & 0.5 & 257 & 30.9 & $<1$ & $<0.8$ & $<5$ & 0.4 & 1.4 & 10.9 & $<0.3$ & 1.6 & 1.04 & 4.1 & 45 & $<0.3$ \\
\hline$C-2$ & 4/7/1998 & 14.58 & 413 & 8.23 & NA & 0.21 & 2.8 & & 28.0 & NA & NA & 0.5 & 250 & 30.2 & $<1$ & $<0.8$ & $<5$ & 0.4 & 1.4 & 10.8 & $<0.3$ & 1.5 & 1.01 & 4.0 & 44 & 1.4 \\
\hline$C-3$ & 4/7/ 1998 & & & 8.26 & NA & 0.21 & 2.8 & & 27.8 & NA & NA & 0.6 & 237 & 28.6 & $<1$ & $<0.8$ & $<5$ & 0.4 & 1.3 & 10.4 & $<0.3$ & 1.5 & 0.95 & 3.8 & 41 & $<0.3$ \\
\hline C-1 & $4 / 26 / 1998$ & 28.22 & 799 & 8.10 & NA & 0.21 & 6.2 & 15.2 & 26.2 & NA & NA & 0.5 & 217 & 26.7 & $<1$ & $<0.8$ & $<5$ & 0.3 & 1.1 & 9.6 & $<0.3$ & 1.3 & 0.87 & 3.5 & 38 & $<0.3$ \\
\hline C-2 & $4 / 26 / 1998$ & 28.25 & 800 & 8.08 & NA & 0.21 & & & 26.2 & NA & NA & 0.5 & 214 & 25.7 & $<1$ & $<0.8$ & $<5$ & 0.3 & 1.1 & 9.2 & $<0.3$ & 1.4 & 0.88 & 3.5 & 38 & $<0.3$ \\
\hline C-3 & 4/26/1998 & & & 8.08 & NA & 0.21 & & & 25.8 & NA & NA & 0.6 & 213 & 26.5 & $<1$ & $<0.8$ & $<5$ & 0.3 & 1.1 & 9.5 & $<0.3$ & 1.5 & 0.88 & 3.4 & 39 & $<0.3$ \\
\hline C-1 & $5 / 18 / 1998$ & 105.59 & 2990 & 7.97 & 11.1 & 0.18 & 4.8 & 2.5 & 22.0 & NA & NA & 0.5 & 193 & 24.6 & $<1$ & $<0.8$ & $<5$ & 0.2 & 0.8 & 8.7 & $<0.3$ & 1.2 & 0.83 & 2.7 & 35 & $<0.3$ \\
\hline$C-2$ & $5 / 18 / 1998$ & 103.32 & 2926 & 8.00 & 11.3 & 0.18 & & & 21.9 & NA & NA & 0.5 & 194 & 24.8 & $<1$ & $<0.8$ & $<5$ & 0.2 & 0.8 & 8.8 & $<0.3$ & 1.1 & 0.82 & 2.7 & 36 & $<0.3$ \\
\hline$c-3$ & 5/18/1998 & & & 7.98 & 11.2 & 0.18 & & & 21.8 & NA & NA & 0.5 & 190 & 24.5 & $<1$ & $<0.8$ & $<5$ & 0.2 & 0.8 & 8.7 & $<0.3$ & 1.1 & 0.81 & 2.6 & 36 & $<0.3$ \\
\hline C-1 & 6/6/1998 & 103.0 & 2917 & 7.98 & NA & 0.18 & 7.3 & 19.6 & NA & 96 & NA & 0.5 & 188 & 24.4 & $<1$ & $<0.8$ & $<5$ & 0.2 & 0.7 & 8.6 & $<0.3$ & 1.1 & 0.77 & 2.6 & 35 & $<0.3$ \\
\hline$C-2$ & 6/6/1998 & 108.67 & 3078 & 8.00 & NA & 0.18 & & & NA & 90 & NA & 0.6 & 185 & 24.0 & $<1$ & $<0.8$ & $<5$ & 0.2 & 0.7 & 8.5 & $<0.3$ & 1.0 & 0.75 & 2.5 & 34 & $<0.3$ \\
\hline C-3 & $6 / 6 / 1998$ & & & 7.99 & NA & 0.18 & & & NA & 90 & NA & 0.5 & 189 & 24.4 & $<1$ & $<0.8$ & $<5$ & 0.2 & 0.7 & 8.6 & $<0.3$ & 1.0 & 0.77 & 2.6 & 36 & $<0.3$ \\
\hline C-1 & $7 / 20 / 1998$ & 62.75 & 1777 & 8.39 & 9.3 & 0.21 & 7.9 & 20.3 & NA & 110 & NA & 0.5 & 234 & 28.1 & $<1$ & $<0.8$ & $<5$ & 0.3 & 1.1 & 10.3 & $<0.3$ & 1.4 & 0.70 & 3.4 & 50 & $<0.3$ \\
\hline C-2 & $7 / 20 / 1998$ & 60.07 & 1701 & 8.40 & 9.6 & 0.21 & 7.9 & 20.2 & NA & 106 & NA & 0.5 & 232 & 28.2 & $<1$ & $<0.8$ & $<5$ & 0.3 & 1.1 & 10.4 & $<0.3$ & 1.4 & 0.70 & 3.4 & 50 & $<0.3$ \\
\hline C-3 & $7 / 20 / 1998$ & & & 8.40 & & 0.21 & 8.0 & 20.2 & NA & 109 & NA & 0.6 & 230 & 28.0 & $<1$ & $<0.8$ & $<5$ & 0.3 & 1.0 & 10.5 & $<0.3$ & 1.5 & 0.67 & 3.3 & 49 & $<0.3$ \\
\hline \multicolumn{27}{|c|}{ Landers Fork site "LA" } \\
\hline LA-1 & $4 / 26 / 1998$ & 32.68 & 925 & 8.14 & 15.5 & 0.21 & 8.6 & 17.4 & 26.4 & NA & NA & 0.4 & 129 & 27.2 & $<1$ & $<0.8$ & $<5$ & 0.4 & 1.7 & 9.2 & 0.6 & 1.1 & 0.90 & 2.3 & 35 & $<0.3$ \\
\hline LA-2 & $4 / 26 / 1998$ & 30.51 & 864 & 8.16 & 16.5 & 0.20 & & & 26.8 & NA & NA & 0.4 & 121 & 26.7 & $<1$ & $<0.8$ & $<5$ & 0.4 & 1.7 & 9.1 & 0.6 & 1.1 & 0.86 & 2.2 & 35 & $<0.3$ \\
\hline LA-3 & 4/26/1998 & & & 8.14 & & 0.20 & & & 26.0 & NA & NA & 0.4 & 126 & 27.2 & $<1$ & $<0.8$ & $<5$ & 0.4 & 1.7 & 9.2 & 0.7 & 1.1 & 0.92 & 2.3 & 35 & $<0.3$ \\
\hline LA-1 & $5 / 18 / 1998$ & 149.14 & 4224 & 8.04 & 10.2 & 0.20 & 7.0 & 5.0 & 25.7 & NA & NA & 0.3 & 112 & 27.5 & $<1$ & $<0.8$ & $<5$ & 0.3 & 1.7 & 9.8 & $<0.3$ & 1.0 & 0.90 & 2.2 & 31 & $<0.3$ \\
\hline LA-2 & $5 / 18 / 1998$ & 148.71 & 4211 & 8.04 & 10.2 & 0.21 & & & 24.6 & NA & NA & 0.4 & 112 & 27.3 & $<1$ & $<0.8$ & $<5$ & 0.3 & 1.6 & 9.7 & $<0.3$ & 1.0 & 0.90 & 2.2 & 31 & $<0.3$ \\
\hline LA-3 & $5 / 18 / 1998$ & & & 8.05 & 10.1 & 0.21 & & & 25.4 & NA & NA & 0.4 & 112 & 27.2 & $<1$ & $<0.8$ & $<5$ & 0.3 & 1.6 & 9.7 & $<0.3$ & 1.0 & 0.90 & 2.2 & 31 & $<0.3$ \\
\hline LA-1 & 6/6/1998 & 144.88 & 4103 & 8.08 & NA & 0.21 & 8.9 & 20.8 & NA & 108 & NA & 0.4 & 120 & 29.2 & $<1$ & $<0.8$ & $<5$ & 0.3 & 1.8 & 10.3 & $<0.3$ & 1.2 & 0.93 & .3 & 34 & $<0.3$ \\
\hline LA-2 & $6 / 6 / 1998$ & 139.77 & 3958 & 8.09 & NA & 0.21 & & & NA & 108 & NA & 0.4 & 119 & 28.9 & $<1$ & $<0.8$ & $<5$ & 0.3 & 1.8 & 10.3 & $<0.3$ & 1.1 & 0.92 & 2.3 & 33 & $<0.3$ \\
\hline LA-3 & $6 / 6 / 1998$ & & & 8.09 & NA & 0.21 & & & NA & 106 & NA & 0.4 & 120 & 29.0 & $<1$ & $<0.8$ & $<5$ & 0.3 & 1.8 & 10.3 & $<0.3$ & 1.0 & 0.92 & 2.3 & 33 & $<0.3$ \\
\hline LA-1 & $7 / 20 / 1998$ & 64.49 & 1826 & 8.52 & 8.5 & 0.25 & 11.9 & 22.8 & NA & 12 & NA & 0.4 & 150 & 34.1 & 1 & $<0.8$ & $<5$ & 0.4 & 2.5 & 12.7 & $<0.3$ & 1.5 & 0.86 & 3.0 & 48 & $<0.3$ \\
\hline LA-2 & $7 / 20 / 1998$ & & & 8.52 & 8.5 & 0.25 & 11.9 & 22.7 & NA & 127 & NA & 0.4 & 152 & 34.7 & $<1$ & $<0.8$ & $<5$ & 0.4 & 2.6 & 12.9 & $<0.3$ & 1.5 & 0.86 & 3.0 & 49 & $<0.3$ \\
\hline LA-3 & $7 / 20 / 1998$ & & & 8.51 & 8.5 & 0.25 & 11.8 & 22.7 & NA & 129 & NA & 0.4 & 153 & 34.7 & $<1$ & $<0.8$ & $<5$ & 0.4 & 2.5 & 12.9 & $<0.3$ & 1.5 & 0.88 & 3.1 & 49 & $<0.3$ \\
\hline \multicolumn{27}{|l|}{ Land } \\
\hline LB-1 & $4 /$ & 1.18 & 33 & 7.78 & 11.0 & 0.27 & 5.3 & 7.4 & 34 & NA & NA & 0.3 & 238 & 38.6 & $<1$ & $<0.8$ & $<5$ & 0.6 & 2.6 & 13.1 & $<0.3$ & 1.6 & 1.1 & 3.7 & 50 & $<0.3$ \\
\hline LB-2 & 4/7/1998 & 1.69 & 48 & 7.79 & 10.8 & 0.26 & 5.4 & & 35.1 & NA & NA & 0.3 & 245 & 39.7 & $<1$ & $<0.8$ & $<5$ & 0.6 & 2.6 & 13.2 & $<0.3$ & 1.5 & 1.2 & 3.8 & 51 & 0.4 \\
\hline LB-3 & 4/7/ 1998 & & & 7.78 & 11.0 & 0.27 & 5.3 & & 34.9 & NA & NA & 0.3 & 245 & 40.1 & $<1$ & $<0.8$ & $<5$ & 0.6 & 2.6 & 13.3 & $<0.3$ & 1.6 & 1.2 & 3.7 & 51 & 2.1 \\
\hline LB-1 & $4 /$ & 3.63 & 103 & 7.72 & 15.0 & 0.28 & 7.8 & 16.9 & 36 & $\mathrm{~N}$ & NA & 0. & 264 & 42.9 & $<1$ & $<0.8$ & $<5$ & 0.6 & 2.7 & 14.2 & $<0.3$ & 1.6 & 1.2 & 3.9 & 56 & $<0.3$ \\
\hline LB-2 & $4 / 26 / 1998$ & 3.6 & 102 & 7.70 & 15.5 & 0.28 & & & 36.2 & NA & NA & 0.3 & 263 & 42.7 & $<1$ & $<0.8$ & $<5$ & 0.6 & 2.6 & 14.1 & $<0.3$ & 1.6 & 1.2 & 3.8 & 55 & $<0.3$ \\
\hline LB-3 & 4/26/1998 & & & 7.72 & & 0.28 & & & 36.5 & NA & NA & 0.2 & 269 & 43.1 & $<1$ & $<0.8$ & $<5$ & 0.6 & 2.6 & 13.8 & $<0.3$ & 1.5 & 1.3 & 3.9 & 55 & $<0.3$ \\
\hline LB-1 & 9/1998 & 218 & 6174 & 7.72 & 12 & 0.2 & 2.5 & -1.5 & 2 & $\mathrm{~N}$ & $\mathrm{~N} / \mathrm{A}$ & & 15 & 28 & 1.0 & $<0$ & $<5$ & 0.3 & 1. & 10.1 & $<0.3$ & 1.1 & 0.91 & 2.5 & 36 & $<0.3$ \\
\hline LB-2 & $5 / 19 / 1998$ & 219 & 6202 & 7.75 & 12.1 & 0.21 & & & 25.1 & NA & NA & 0.4 & 153 & 28.5 & $<1$ & $<0.8$ & $<5$ & 0.3 & 1.5 & 10.0 & $<0.3$ & 1.1 & 0.91 & 2.5 & 36 & $<0.3$ \\
\hline
\end{tabular}




\begin{tabular}{|c|c|c|c|c|c|c|c|c|c|c|c|c|c|c|c|c|c|c|c|c|c|c|c|c|c|c|}
\hline \begin{tabular}{|l|} 
SAMPLE \\
NAME
\end{tabular} & $\begin{array}{l}\text { SAMPLE } \\
\text { DATE }\end{array}$ & $\begin{array}{l}\text { STREAM- } \\
\text { FLOW }\end{array}$ & $\begin{array}{l}\text { STREAM- } \\
\text { FLOW } \\
\text { (I) }\end{array}$ & $\mathrm{pH}$ & $\begin{array}{l}\text { D.O. } \\
(\mathrm{mg} / \mathrm{L})\end{array}$ & $\begin{array}{l}\text { Con- } \\
\text { ductivity } \\
(\mathrm{ms} / \mathrm{cm}\end{array}$ & $\begin{array}{l}\text { Water } \\
\text { Temp } \\
\text { (Cel) }\end{array}$ & $\begin{array}{l}\text { Air } \\
\text { Temp } \\
\text { (Cel) }\end{array}$ & $\begin{array}{l}\text { Inorganic } \\
\text { Carbon } \\
\text { (mg/L) }\end{array}$ & $\begin{array}{l}\text { Total } \\
\text { Alkalinity } \\
\text { (mg/L CaO }\end{array}$ & $\begin{array}{l}\text { Sulfat } \\
\left.\mathrm{CO}_{3}\right)\end{array}$ & As & $\begin{array}{l}\mathrm{Ba} \\
\mathrm{ga} / \mathrm{L})\end{array}$ & $\begin{array}{l}\mathrm{Ca} \\
(\mathrm{mg} / \mathrm{L})\end{array}$ & $\begin{array}{ll}\mathrm{Cr} \\
(\mu \mathrm{L} / \mathrm{L})\end{array}$ & $\begin{array}{l}\mathrm{Cu} \\
\text { (ug/L) }\end{array}$ & $\begin{array}{ll}\mathrm{Fe} \\
\end{array}$ & $\begin{array}{l}\mathrm{K} \\
(\mathrm{mg} / \mathrm{L})\end{array}$ & $\begin{array}{l}\mathrm{Li} \\
(\mu \mathrm{g} / \mathrm{L})\end{array}$ & $\begin{array}{l}\mathrm{Mg} \\
(\mathrm{mg} / \mathrm{L})\end{array}$ & $\begin{array}{l}\text { Mn } \\
(\mu \mathrm{g} / \mathrm{L})\end{array}$ & $\begin{array}{l}\mathrm{Na} \\
(\mathrm{mg} / \mathrm{L})\end{array}$ & $\begin{array}{l}\mathrm{S} \\
(\mathrm{mg} / \mathrm{L})\end{array}$ & $\begin{array}{l}\mathrm{Si} \\
(\mathrm{mg} / \mathrm{L})\end{array}$ & $\begin{array}{l}\text { Sr } \\
(\mu \mathrm{g} / \mathrm{L})\end{array}$ & $\begin{array}{l}\mathrm{Zn} \\
(\mu \mathrm{g} / \mathrm{L})\end{array}$ \\
\hline LB-3 & $5 / 19 / 1998$ & & & $\frac{\text { (units) }}{7.72}$ & $\frac{(\mathrm{mg} / \mathrm{L})}{11.9}$ & $\frac{(\mathrm{mS} / \mathrm{cm})}{0.21}$ & & & $\frac{(\mathrm{mg} / \mathrm{L})}{25.5}$ & $\frac{(\mathrm{mg} / \mathrm{L} \mathrm{CaC}}{\mathrm{NA}}$ & $\begin{array}{l}\left(0_{3}\right) \\
N A\end{array}$ & $\frac{(\mu \mathrm{g} / \mathrm{L})}{0.4}$ & $\frac{(\mu \mathrm{g} / \mathrm{L})}{151}$ & $\frac{(\mathrm{mg} / \mathrm{L})}{28.5}$ & $\frac{(\mu \mathrm{g} / \mathrm{L})}{<1}$ & $\frac{(\mu \mathrm{g} / \mathrm{L})}{<0.8}$ & $\frac{(\mu \mathrm{g} / \mathrm{L})}{<5}$ & $\frac{(\mathrm{mg} / \mathrm{L})}{0.3}$ & $\frac{(\mu \mathrm{g} / \mathrm{L})}{1.5}$ & $\frac{(\mathrm{mg} / \mathrm{L})}{10.0}$ & $\frac{(\mu \mathrm{g} / \mathrm{L})}{<0.3}$ & $\frac{(\mathrm{mg} / \mathrm{L})}{1.2}$ & $\frac{(\mathrm{mg} / \mathrm{L})}{0.92}$ & $\frac{(\mathrm{mg} / \mathrm{L})}{2.5}$ & $\frac{(\mu \mathrm{g} / \mathrm{L})}{36}$ & $\frac{(\mu \mathrm{g} / \mathrm{L})}{<0.3}$ \\
\hline LB-1 & $6 / 6 / 1998$ & 252 & 7137 & 7.99 & 13.0 & 0.21 & 6.3 & 15.1 & NA & 112 & NA & 0.4 & 153 & 28.1 & $<1$ & $<0.8$ & $<5$ & 0.3 & 1.5 & 9.9 & $<0.3$ & 1.0 & 0.89 & 2.5 & 36 & $<0.3$ \\
\hline LB-2 & $6 / 6 / 1998$ & 256 & 7250 & 8.00 & 13.2 & 0.21 & & & NA & 110 & NA & 0.4 & 152 & 28.4 & $<1$ & $<0.8$ & $<5$ & 0.3 & 1.5 & 9.9 & $<0.3$ & 1.0 & 0.88 & 2.5 & 36 & $<0.3$ \\
\hline LB-3 & $6 / 6 / 1998$ & & & 7.98 & 13.2 & 0.21 & & & NA & 116 & NA & 0.4 & 155 & 28.6 & $<1$ & $<0.8$ & $<5$ & 0.3 & 1.6 & 10.0 & $<0.3$ & 1.1 & 0.89 & 2.6 & 36 & $<0.3$ \\
\hline LB-1 & 6/29/1998 & 413 & 11696 & 7.96 & 12.1 & 0.20 & 7.9 & 17.0 & NA & 107 & NA & 0.4 & 148 & 29.2 & $<1$ & $<0.8$ & $<5$ & 0.3 & 1.5 & 10.2 & 0.5 & 1.3 & 0.83 & 2.7 & 36 & $<0.3$ \\
\hline LB-2 & 6/29/1998 & 420 & 11894 & 7.98 & 11.9 & 0.20 & 8.0 & 17.0 & NA & 110 & NA & 0.4 & 150 & 29.5 & 1.7 & $<0.8$ & $<5$ & 0.4 & 1.5 & 10.2 & 0.4 & 1.6 & 0.86 & 2.9 & 37 & $<0.3$ \\
\hline LB-3 & $6 / 29 / 1998$ & & & 7.98 & 12.0 & 0.20 & 8.1 & 17.1 & NA & 106 & NA & 0.4 & 151 & 29.7 & $<1$ & $<0.8$ & $<5$ & 0.3 & 1.6 & 10.3 & 0.5 & 1.2 & 0.84 & 2.7 & 37 & $<0.3$ \\
\hline LB-1 & $7 / 20 / 1998$ & 129 & 3653 & 8.32 & 8.1 & 0.25 & 12.9 & 23.9 & NA & 121 & NA & 0.4 & 212 & 32.9 & $<1$ & $<0.8$ & $<5$ & 0.4 & 2.1 & 12.1 & $<0.3$ & 1.7 & 0.82 & 3.4 & 51 & $<0.3$ \\
\hline LB-2 & $7 / 20 / 1998$ & 133 & 3767 & 8.35 & 8.2 & 0.25 & 12.9 & 24.0 & NA & 124 & NA & 0.4 & 211 & 33.0 & $<1$ & $<0.8$ & $<5$ & 0.4 & 2.0 & 12.0 & $<0.3$ & 1.5 & 0.81 & 3.4 & 51 & $<0.3$ \\
\hline LB-3 & $7 / 20 / 1998$ & & & 8.35 & 8.2 & 0.25 & 13.0 & 24.0 & NA & 124 & NA & 0.4 & 213 & 32.0 & $<1$ & $<0.8$ & $<5$ & 0.4 & 1.9 & 11.8 & $<0.3$ & 1.4 & 0.81 & 3.4 & 50 & $<0.3$ \\
\hline LB-1 & 9/4/ 1998 & 25.91 & 734 & 7.86 & 9.1 & 0.26 & 11.5 & 23.9 & 33.7 & 125 & NA & 0.4 & 239 & 33.6 & $<1$ & $<0.8$ & $<5$ & 0.5 & 2.2 & 11.8 & $<0.3$ & 0.8 & 0.84 & 4.0 & 53 & $<0.3$ \\
\hline LB-2 & 9/4/1998 & 24.41 & 691 & 7.88 & 9.0 & 0.27 & 11.6 & 23.8 & 33.9 & 128 & NA & 0.4 & 241 & 34.2 & $<1$ & $<0.8$ & $<5$ & 0.5 & 2.3 & 12.0 & $<0.3$ & 0.8 & 0.85 & 4.0 & 54 & $<0.3$ \\
\hline LB-3 & 9/4/1998 & & & 7.86 & 9.0 & 0.27 & 11.5 & 23.7 & 34.1 & 128 & NA & 0.4 & 241 & 33.6 & $<1$ & $<0.8$ & $<5$ & 0.5 & 2.2 & 11.9 & $<0.3$ & 0.7 & 0.85 & 4.0 & 54 & $<0.3$ \\
\hline LB-1 & 10/6/1998 & 17.44 & 494 & 7.66 & 8.6 & 0.26 & 9.1 & 12.5 & 34.2 & 135 & 2.9 & 0.5 & 234 & 33.9 & $<1$ & $<0.8$ & $<5$ & 0.5 & 2.4 & 12.0 & $<0.3$ & 0.6 & 0.87 & 3.9 & 53 & 0.5 \\
\hline LB-2 & 10/6/1998 & & & 7.68 & 8.6 & 0.26 & 9.0 & & 34.2 & 140 & 3.0 & 0.5 & 236 & 34.3 & $<1$ & $<0.8$ & $<5$ & 0.5 & 2.3 & 12.1 & $<0.3$ & 0.7 & 0.87 & 3.9 & 54 & $<0.3$ \\
\hline LB-3 & 10/6/1998 & & & 7.67 & 8.7 & 0.26 & & & 34.5 & 133 & 3.0 & 0.5 & 236 & 34.0 & $<1$ & $<0.8$ & $<5$ & 0.5 & 2.3 & 12.0 & $<0.3$ & 0.9 & 0.88 & 3.9 & 53 & $<0.3$ \\
\hline LB-1 & $11 / 7 / 1998$ & 4.58 & 130 & 7.92 & 11.1 & 0.27 & 4.0 & -5.1 & NA & 132 & NA & 0.2 & 240 & 34.8 & $<1$ & $<0.8$ & $<5$ & 0.5 & 2.4 & 12.4 & $<0.3$ & 0.7 & 0.90 & 4.0 & 55 & $<0.3$ \\
\hline LB-2 & $11 / 7 / 1998$ & & & 7.91 & 11.1 & 0.27 & 4.0 & & NA & 133 & NA & 0.2 & 247 & 34.8 & $<1$ & $<0.8$ & $<5$ & 0.6 & 2.5 & 12.5 & $<0.3$ & 0.8 & 0.92 & 4.1 & 56 & $<0.3$ \\
\hline LB-3 & $11 / 7 / 1998$ & & & 7.91 & 11.0 & 0.27 & & & NA & 133 & NA & 0.2 & 248 & 34.9 & $<1$ & $<0.8$ & $<5$ & 0.6 & 2.4 & 12.5 & $<0.3$ & 0.8 & 0.93 & 4.2 & 57 & $<0.3$ \\
\hline \multicolumn{27}{|l|}{ LB Seeps } \\
\hline LB SEEP-1 & 4/7/1998 & & & 7.44 & 6.7 & 0.26 & 5.0 & 8.0 & 35.8 & NA & NA & 0.3 & 215 & 33.4 & $<1$ & $<0.8$ & $<5$ & 0.5 & 2.3 & 11.6 & $<0.3$ & 1.8 & 1.0 & 3.4 & 43 & $<0.3$ \\
\hline LB SEEP-2 & 4/7/1998 & & & 7.47 & 6.9 & 0.27 & 5.1 & 8.1 & 35.8 & NA & NA & 0.3 & 226 & 25.2 & $<1$ & $<0.8$ & $<5$ & 0.4 & 1.7 & 8.5 & $<0.3$ & 1.0 & 1.1 & 3.5 & 34 & 1.4 \\
\hline LB SEEP-3 & 4/7/1998 & & & 7.45 & 7.2 & 0.27 & 5.0 & 8.0 & 35.6 & NA & NA & 0.3 & 240 & 38.0 & $<1$ & $<0.8$ & $<5$ & 0.6 & 2.7 & 12.9 & $<0.3$ & 1.7 & 1.1 & 3.8 & 50 & 1.1 \\
\hline LB SEEP-1 & 4/26/1998 & & & 7.69 & 14.0 & 0.28 & 4.6 & & 36.4 & NA & NA & 0.3 & 253 & 41.6 & $<1$ & $<0.8$ & $<5$ & 0.7 & 2.8 & 13.9 & $<0.3$ & 1.8 & 1.2 & 4.0 & 55 & $<0.3$ \\
\hline LB SEEP-2 & $4 / 26 / 1998$ & & & 7.67 & & 0.28 & & & 35.7 & NA & NA & 0.3 & 251 & 41.0 & $<1$ & $<0.8$ & $<5$ & 0.6 & 2.7 & 13.8 & $<0.3$ & 1.6 & 1.2 & 3.9 & 53 & $<0.3$ \\
\hline LB SEEP-3 & 4/26/1998 & & & 7.67 & & 0.28 & & & 36.1 & NA & NA & 0.3 & 252 & 40.8 & $<1$ & $<0.8$ & $<5$ & 0.6 & 2.8 & 13.8 & $<0.3$ & 1.7 & 1.2 & 4.0 & 53 & $<0.3$ \\
\hline \multicolumn{27}{|c|}{ Landers Fork, site "LC" } \\
\hline LC-1 & 4/7/1998 & 24.07 & 682 & 7.97 & 9.9 & 0.25 & 6.3 & 8.2 & 33. & $\mathrm{~N}$ & NA & 1.0 & 262 & 37.2 & $<1$ & $<0.8$ & $<5$ & 0.6 & 2.4 & 12.5 & $<0.3$ & 1.6 & 1.2 & 4.0 & 55 & $<0.3$ \\
\hline LC-2 & 4/7/1998 & 24.75 & 701 & 7.95 & 9.9 & 0.25 & 6.3 & & 33.9 & NA & NA & 1.0 & 253 & 35.8 & $<1$ & $<0.8$ & $<5$ & 0.5 & 2.3 & 12.0 & $<0.3$ & 1.6 & 1.1 & 3.9 & 53 & $<0.3$ \\
\hline LC-3 & 4/7/1998 & & & 7.98 & 9.8 & 0.25 & 6.2 & & 33.7 & NA & NA & 1.0 & 254 & 34.2 & $<1$ & $<0.8$ & $<5$ & 0.5 & 2.1 & 11.6 & $<0.3$ & 1.5 & 1.1 & 3.9 & 50 & $<0.3$ \\
\hline LC-1 & $4 / 26 / 1998$ & 25.39 & 719 & 7.80 & 17.0 & 0.27 & 7.6 & 15.8 & 33. & $\mathrm{~N}$ & NA & 0.9 & 275 & 36.3 & 1.1 & $<0.8$ & $<5$ & 0.5 & 2.3 & 13.0 & $<0.3$ & 1.6 & 1.2 & 4.0 & 54 & $<0.3$ \\
\hline LC-2 & $4 / 26 / 1998$ & 24.5 & 694 & 7.80 & 18.0 & 0.27 & & & 33.8 & NA & NA & 0.9 & 278 & 37.5 & $<1$ & $<0.8$ & $<5$ & 0.6 & 2.4 & 13.4 & $<0.3$ & 1.6 & 1.2 & 4.0 & 55 & $<0.3$ \\
\hline LC-3 & 4/26/1998 & & & 7.82 & & 0.27 & & & 34.5 & NA & NA & 0.9 & 279 & 37.4 & $<1$ & $<0.8$ & $<5$ & 0.5 & 2.4 & 13.4 & $<0.3$ & 1.6 & 1.2 & 4.0 & 55 & $<0.3$ \\
\hline LC-1 & $5 / 19 / 1998$ & 286.08 & 8102 & 7.74 & 10.5 & 0.22 & 3.2 & 7.0 & 26.0 & NA & NA & 0.4 & 169 & 29.4 & $<1$ & $<0.8$ & $<5$ & 0.4 & 1.6 & 10.4 & $<0.3$ & 1.1 & 0.95 & 2.7 & 38 & $<0.3$ \\
\hline LC-2 & $5 / 19 / 1998$ & 284.82 & 8066 & 7.77 & 10.5 & 0.22 & & & 26.2 & NA & NA & 0.4 & 169 & 29.3 & 1.0 & $<0.8$ & $<5$ & 0.3 & 1.6 & 10.4 & $<0.3$ & 1.2 & 0.94 & 2.7 & 38 & $<0.3$ \\
\hline LC-3 & 5/19/1998 & & & 7.71 & 10.6 & 0.22 & & & 26.0 & NA & NA & 0.4 & 167 & 29.2 & $<1$ & $<0.8$ & $<5$ & 0.3 & 1.6 & 10.3 & $<0.3$ & 1.1 & 0.94 & 2.7 & 38 & $<0.3$ \\
\hline LC-1 & $6 / 6 / 1998$ & 29 & 8277 & 7.8 & 11.8 & 0.22 & 5.2 & 8.0 & NA & 11 & $\mathrm{~N}$ & 0. & 168 & 29 & $<1$ & $<0.8$ & $<5$ & 0.3 & 1.6 & 10.3 & $<0.3$ & 1.1 & 0.91 & 2.7 & 38 & $<0.3$ \\
\hline LC-2 & 6/6/1998 & 308.52 & 8737 & 7.85 & 11.7 & 0.22 & & & NA & 112 & NA & 0.5 & 168 & 29.3 & $<1$ & $<0.8$ & $<5$ & 0.3 & 1.6 & 10.3 & $<0.3$ & 1.1 & 0.90 & 2.7 & 38 & $<0.3$ \\
\hline LC-3 & 6/6/1998 & & & 7.86 & 11.7 & 0.22 & & & NA & 114 & NA & 0.5 & 169 & 29.1 & $<1$ & $<0.8$ & $<5$ & 0.3 & 1.6 & 10.3 & $<0.3$ & 1.1 & 0.91 & 2.7 & 38 & $<0.3$ \\
\hline
\end{tabular}




\begin{tabular}{|c|c|c|c|c|c|c|c|c|c|c|c|c|c|c|c|c|c|c|c|c|c|c|c|c|c|c|}
\hline \begin{tabular}{|l} 
SAMPLE \\
NAME
\end{tabular} & $\begin{array}{l}\text { SAMPLE } \\
\text { DATE }\end{array}$ & $\begin{array}{l}\text { STREAM- } \\
\text { FLOW }\end{array}$ & $\begin{array}{l}\text { STREAM- } \\
\text { FLOW }\end{array}$ & $\mathrm{pH}$ & D.O. & $\begin{array}{l}\text { Con- } \\
\text { ductivity }\end{array}$ & $\begin{array}{l}\text { Water } \\
\text { Temp }\end{array}$ & $\begin{array}{l}\text { Air } \\
\text { Temp }\end{array}$ & $\begin{array}{l}\text { Inorganic } \\
\text { Carbon }\end{array}$ & $\begin{array}{l}\text { Total } \\
\text { Alkalinity }\end{array}$ & Sulfate & & $\mathrm{Ba}$ & $\mathrm{Ca}$ & $\mathrm{Cr}$ & $\mathrm{Cu}$ & $\mathrm{Fe}$ & $\mathrm{K}$ & $\overline{\mathrm{Li}}$ & $\mathrm{Mg}$ & $\mathrm{Mn}$ & $\mathrm{Na}$ & & & $\mathrm{Sr}$ & $\mathrm{Zn}$ \\
\hline & & $(\mathrm{cfs})$ & $(\mathrm{L} / \mathrm{s})$ & (units) & $(\mathrm{mg} / \mathrm{L})$ & $(\mathrm{mS} / \mathrm{cm})$ & (Cel.) & (Cel.) & $(\mathrm{mg} / \mathrm{L})$ & $(\mathrm{mg} / \mathrm{L} \mathrm{CaCl}$ & $\left.\mathrm{CO}_{3}\right)$ & $(\mu \mathrm{g} / \mathrm{L})$ & $(\mu \mathrm{g} / \mathrm{L})$ & $(\mathrm{mg} / \mathrm{L})$ & $(\mu \mathrm{g} / \mathrm{L})$ & $(\mu \mathrm{g} / \mathrm{L})$ & $(\mu \mathrm{g} / \mathrm{L})$ & $(\mathrm{mg} / \mathrm{L})$ & $(\mu \mathrm{g} / \mathrm{L})$ & $(\mathrm{mg} / \mathrm{L})$ & $(\mu \mathrm{g} / \mathrm{L})$ & $(\mathrm{mg} / \mathrm{L})$ & $(\mathrm{mg} / \mathrm{L})$ & $(\mathrm{mg} / \mathrm{L})$ & $(\mu \mathrm{g} / \mathrm{L})$ & $(\mu \mathrm{g} / \mathrm{L})$ \\
\hline LC-1 & $6 / 29 / 1998$ & 554 & 15689 & 8.23 & 10.8 & 0.21 & 11.8 & 27.1 & $\mathrm{NA}$ & 108 & NA & 0.5 & 166 & 29.8 & 1.1 & $<0.8$ & $<5$ & 0.4 & 1.6 & 10.3 & 0.6 & 1.3 & 0.88 & 2.8 & 38 & $<0.3$ \\
\hline LC-2 & $6 / 29 / 1998$ & & & 8.21 & 10.8 & 0.21 & 11.9 & 27.0 & NA & 107 & NA & 0.5 & 163 & 30.0 & 1.5 & $<0.8$ & $<5$ & 0.4 & 1.6 & 10.4 & 0.6 & 1.3 & 0.87 & 2.8 & 38 & $<0.3$ \\
\hline LC-3 & $6 / 29 / 1998$ & & & 8.22 & 10.9 & 0.21 & 11.9 & 27.1 & NA & 104 & NA & 0.5 & 162 & 30.3 & 1.3 & $<0.8$ & $<5$ & 0.4 & 1.6 & 10.3 & 0.6 & 1.4 & 0.87 & 2.9 & 39 & $<0.3$ \\
\hline LC-1 & $7 / 20 / 1998$ & 177.69 & 5032 & 8.33 & 8.5 & 0.25 & 13.9 & 26.7 & NA & 122 & NA & 0.5 & 230 & 33.9 & $<1$ & $<0.8$ & $<5$ & 0.4 & 2.2 & 12.4 & 0.3 & 1.7 & 0.84 & 3.6 & 54 & $<0.3$ \\
\hline LC- 2 & $7 / 20 / 1998$ & & & 8.32 & 8.5 & 0.25 & 13.8 & 26.7 & NA & 118 & NA & 0.5 & 229 & 33.6 & $<1$ & $<0.8$ & $<5$ & 0.4 & 2.2 & 12.3 & 0.3 & 1.5 & 0.82 & 3.6 & 53 & $<0.3$ \\
\hline LC-3 & $7 / 20 / 1998$ & & & 8.32 & 8.5 & 0.25 & 13.8 & 26.8 & NA & 122 & NA & 0.5 & 231 & 33.8 & $<1$ & $<0.8$ & $<5$ & 0.5 & 2.2 & 12.1 & 0.3 & 1.4 & 0.84 & 3.6 & 54 & $<0.3$ \\
\hline LC-1 & 9/4/1998 & 60.36 & 1709 & 7.98 & 9.1 & 0.27 & 11.1 & 22.5 & 34.1 & 131 & NA & 0.6 & 271 & 34.5 & $<1$ & $<0.8$ & $<5$ & 0.6 & 2.4 & 12.1 & $<0.3$ & 0.9 & 0.92 & 4.4 & 59 & $<0.3$ \\
\hline LC-2 & 9/4/1998 & 57.15 & 1618 & 7.98 & 9.1 & 0.27 & 11.2 & 22.7 & 34.4 & 126 & NA & 0.6 & 262 & 34.7 & $<1$ & $<0.8$ & $<5$ & 0.6 & 2.5 & 12.2 & $<0.3$ & 0.8 & 0.88 & 4.4 & 58 & $<0.3$ \\
\hline LC-3 & $9 / 4 / 1998$ & & & 7.99 & 9.1 & 0.27 & 11.2 & 22.7 & 34.5 & 132 & NA & 0.6 & 271 & 34.2 & $<1$ & $<0.8$ & $<5$ & 0.6 & 2.3 & 12.0 & $<0.3$ & 0.8 & 0.90 & 4.4 & 59 & $<0.3$ \\
\hline LC-1 & $10 / 6 / 1998$ & 41.74 & 1182 & 7.88 & 8.9 & 0.26 & 9.4 & 11.8 & 33.9 & 123 & 3.0 & 0.8 & 258 & 33.6 & $<1$ & $<0.8$ & $<5$ & 0.5 & 2.4 & 11.8 & $<0.3$ & 0.8 & 0.88 & 4.3 & 57 & $<0.3$ \\
\hline LC- 2 & $10 / 6 / 1998$ & & & 7.86 & 8.8 & 0.26 & 9.4 & & 33.8 & 128 & 3.0 & 0.8 & 253 & 33.5 & $<1$ & $<0.8$ & $<5$ & 0.5 & 2.4 & 11.8 & $<0.3$ & 0.8 & 0.87 & 4.3 & 56 & $<0.3$ \\
\hline LC-3 & $10 / 6 / 1998$ & & & 7.87 & 8.8 & 0.26 & 9.4 & & 33.5 & 124 & 3.0 & 0.8 & 257 & 34.1 & $<1$ & $<0.8$ & $<5$ & 0.5 & 2.4 & 11.9 & $<0.3$ & 0.8 & 0.88 & 4.3 & 57 & $<0.3$ \\
\hline LC-1 & $11 / 7 / 1998$ & 32.07 & 908 & 8.02 & 11.6 & 0.27 & 4.2 & 0.7 & NA & 131 & NA & 0.4 & 263 & 34.4 & $<1$ & $<0.8$ & $<5$ & 0.5 & 2.4 & 12.2 & $<0.3$ & 0.8 & 0.90 & 4.5 & 59 & $<0.3$ \\
\hline LC-2 & $11 / 7 / 1998$ & & & 8.02 & 11.6 & 0.27 & & & NA & 132 & NA & 0.4 & 255 & 33.6 & $<1$ & $<0.8$ & $<5$ & 0.5 & 2.4 & 11.9 & $<0.3$ & 0.7 & 0.87 & 4.4 & 58 & $<0.3$ \\
\hline LC-3 & 11/7/1998 & & & 8.02 & 11.6 & 0.27 & & & NA & & NA & & & & & & & & & & & & & & & \\
\hline LC-1 & $12 / 5 / 1998$ & 27.01 & 765 & NA & NA & 0.28 & 4.0 & & 33.1 & 135 & NA & 0.4 & 260 & 33.6 & $<1$ & $<0.8$ & $<5$ & 0.5 & 2.3 & 11.9 & $<0.3$ & 0.8 & 0.89 & 4.5 & 59 & $<0.3$ \\
\hline LC-2 & $12 / 5 / 1998$ & & & NA & NA & 0.27 & & & 33.6 & 137 & NA & 0.4 & 263 & 33.5 & $<1$ & $<0.8$ & $<5$ & 0.5 & 2.4 & 11.8 & $<0.3$ & 0.8 & 0.90 & 4.5 & 59 & $<0.3$ \\
\hline LC-3 & $12 / 5 / 1998$ & & & NA & NA & 0.27 & & & 33.9 & 139 & NA & 0.4 & 257 & 33.3 & $<1$ & $<0.8$ & $<5$ & 0.5 & 2.3 & 11.8 & $<0.3$ & 0.9 & 0.88 & 4.5 & 58 & $<0.3$ \\
\hline \multicolumn{27}{|l|}{ LC Seeps } \\
\hline LC SEEP-1 & 4/7/1998 & & & 7.49 & 6.0 & 0.27 & 3.8 & & 36.5 & NA & NA & 0.9 & 289 & 42.2 & $<1$ & $<0.8$ & $<5$ & 0.6 & 2.8 & 13.8 & $<0.3$ & 1.8 & 1.21 & 4.6 & 64 & 2.7 \\
\hline LC SEEP-2 & $4 / 7 / 1998$ & & & 7.49 & 5.8 & 0.27 & 3.9 & & 36.2 & NA & NA & 0.9 & 289 & 42.3 & $<1$ & $<0.8$ & $<5$ & 0.6 & 2.7 & 13.7 & $<0.3$ & 1.8 & 1.23 & 4.6 & 65 & 0.5 \\
\hline LC SEEP-3 & 4/7/1998 & & & 7.50 & 5.9 & 0.27 & 4.0 & & 36.4 & NA & NA & 0.9 & & & & & & & & & & & & & & \\
\hline LC SEEP-1 & $4 / 26 / 1998$ & & & 7.79 & NA & 0.29 & 3.9 & & 37.0 & NA & NA & 0.9 & 287 & 38.9 & $<1$ & $<0.8$ & $<5$ & 0.6 & 2.7 & 13.7 & $<0.3$ & 2.3 & 1.29 & 4.5 & 60 & 0.5 \\
\hline LC SEEP-2 & 4/26/1998 & & & 7.75 & NA & 0.27 & & & 36.9 & NA & NA & 1.0 & 289 & 40.3 & $<1$ & $<0.8$ & $<5$ & 0.6 & 2.7 & 13.9 & $<0.3$ & 2.0 & 1.27 & 4.5 & 62 & $<0.3$ \\
\hline LC SEEP-3 & $4 / 26 / 1998$ & & & 7.79 & NA & 0.29 & & & 36.5 & NA & NA & 0.9 & 287 & 39.6 & $<1$ & $<0.8$ & $<5$ & 0.6 & 2.8 & 14.0 & $<0.3$ & 1.9 & 1.25 & 4.4 & 61 & $<0.3$ \\
\hline LC SEEP-1 & $10 / 6 / 1998$ & & & 7.39 & 6.2 & 0.29 & 7.6 & & 38.9 & 139 & 3.1 & 1.1 & 307 & 39.3 & $<1$ & $<0.8$ & $<5$ & 0.6 & 2.9 & 13.1 & $<0.3$ & 1.0 & 0.93 & 5.5 & 69 & $<0.3$ \\
\hline LC SEEP-2 & $10 / 6 / 1998$ & & & 7.40 & 6.2 & 0.29 & 7.6 & & 38.9 & 143 & 3.2 & 1.1 & 307 & 39.0 & $<1$ & $<0.8$ & $<5$ & 0.7 & 2.9 & 13.1 & $<0.3$ & 0.9 & 0.94 & 5.5 & 68 & $<0.3$ \\
\hline LC SEEP-3 & $10 / 6 / 1998$ & & & 7.40 & 6.2 & 0.30 & 7.6 & & 39.0 & 138 & 3.1 & 1.1 & 310 & 39.6 & $<1$ & $<0.8$ & $<5$ & 0.6 & 2.9 & 13.2 & $<0.3$ & 0.9 & 0.94 & 5.6 & 70 & $<0.3$ \\
\hline LC SEEP-1 & $11 / 7 / 1998$ & & & 7.48 & 8.3 & 0.30 & 5.7 & & NA & 145 & NA & 0.5 & 308 & 37.5 & $<1$ & $<0.8$ & $<5$ & 0.7 & 2.9 & 13.0 & $<0.3$ & 1.0 & 0.95 & 5.7 & 69 & 1.0 \\
\hline LC SEEP-2 & $11 / 7 / 1998$ & & & 7.48 & 8.2 & 0.30 & 5.8 & & NA & & NA & & & & & & & & & & & & & & & \\
\hline LC SEEP-3 & $11 / 7 / 1998$ & & & 7.48 & 8.3 & 0.30 & 5.7 & & NA & & NA & & & & & & & & & & & & & & & \\
\hline LC SEEP-1 & $12 / 5 / 1998$ & & & 7.12 & NA & 0.28 & 6.3 & & 37.4 & 130 & NA & 0.5 & 292 & 36.3 & $<1$ & $<0.8$ & $<5$ & 0.6 & 2.8 & 12.5 & $<0.3$ & 0.9 & 0.93 & 5.4 & 67 & $<0.3$ \\
\hline LC SEEP-2 & $12 / 5 / 1998$ & & & 7.13 & NA & & & & & & NA & & & & & & & & & & & & & & & \\
\hline LC SEEP-3 & $12 / 5 / 1998$ & & & 7.13 & NA & & & & & & NA & & & & & & & & & & & & & & & \\
\hline
\end{tabular}

\section{Landers Fork, Site "LD"}

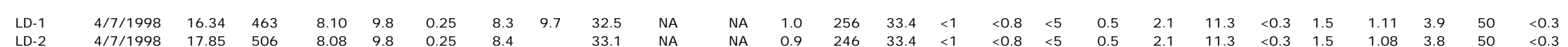

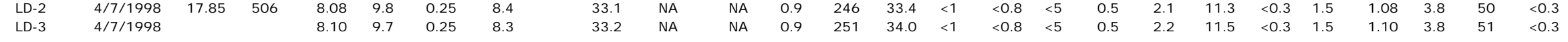

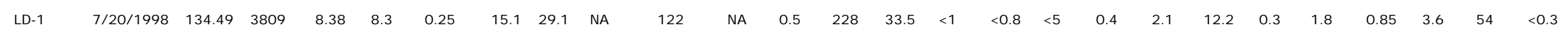




\begin{tabular}{|c|c|c|c|c|c|c|c|c|c|c|c|c|c|c|c|c|c|c|c|c|c|c|c|c|c|c|}
\hline \begin{tabular}{|l|} 
SAMPLE \\
NAME
\end{tabular} & $\begin{array}{l}\text { SAMPLE } \\
\text { DATE }\end{array}$ & $\begin{array}{l}\text { STREAM- } \\
\text { FLOW } \\
\text { (cfs) }\end{array}$ & $\begin{array}{l}\text { STREAM- } \\
\text { FLOW } \\
\text { (L/s) }\end{array}$ & $\begin{array}{l}\mathrm{pH} \\
\text { (units) }\end{array}$ & $\begin{array}{l}\text { D.O. } \\
(\mathrm{mg} / \mathrm{L})\end{array}$ & $\begin{array}{l}\text { Con- } \\
\text { ductivity } \\
(\mathrm{mS} / \mathrm{cm})\end{array}$ & $\begin{array}{l}\text { Water } \\
\text { Temp } \\
\text { (Cel.) }\end{array}$ & $\begin{array}{l}\text { Air } \\
\text { Temp } \\
\text { (Cel.) }\end{array}$ & $\begin{array}{l}\text { Inorganic } \\
\text { Carbon } \\
\text { (mg/L) }\end{array}$ & $\begin{array}{l}\text { Total } \\
\text { Alkalinity } \\
\text { (mg/L CaC }\end{array}$ & $\begin{array}{l}\text { Sulfate } \\
\left.\mathrm{CO}_{3}\right)\end{array}$ & $(\mu \mathrm{g} / \mathrm{L})$ & $\begin{array}{l}\mathrm{Ba} \\
(\mu \mathrm{g} / \mathrm{L})\end{array}$ & $\begin{array}{l}\mathrm{Ca} \\
(\mathrm{mg} / \mathrm{L})\end{array}$ & $\begin{array}{l}\mathrm{Cr} \\
(\mu \mathrm{g} / \mathrm{L})\end{array}$ & $\begin{array}{l}\mathrm{Cu} \\
(\mu \mathrm{g} / \mathrm{L})\end{array}$ & $\begin{array}{l}\mathrm{Fe} \\
(\mu \mathrm{g} / \mathrm{L})\end{array}$ & $\begin{array}{l}\mathrm{K} \\
(\mathrm{mg} / \mathrm{L})\end{array}$ & $\begin{array}{l}\mathrm{Li} \\
(\mu \mathrm{g} / \mathrm{L})\end{array}$ & $\begin{array}{l}\mathrm{Mg} \\
(\mathrm{mg} / \mathrm{L})\end{array}$ & $\begin{array}{l}\mathrm{Mn} \\
(\mu \mathrm{g} / \mathrm{L})\end{array}$ & $\begin{array}{l}\mathrm{Na} \\
(\mathrm{mg} / \mathrm{L})\end{array}$ & $\begin{array}{l}\mathrm{S} \\
(\mathrm{mg} / \mathrm{L})\end{array}$ & $\begin{array}{l}\text { Si } \\
(\mathrm{mg} / \mathrm{L})\end{array}$ & $\begin{array}{l}\mathrm{Sr} \\
(\mu \mathrm{g} / \mathrm{L})\end{array}$ & $\begin{array}{l}\mathrm{Zn} \\
(\mu \mathrm{g} / \mathrm{L})\end{array}$ \\
\hline LD-2 & $7 / 20 / 1998$ & 135.03 & 3824 & 8.39 & 8.3 & 0.25 & 15.1 & 29.1 & NA & 117 & NA & 0.5 & 229 & 33.7 & $<1$ & $<0.8$ & $<5$ & 0.5 & 2.2 & 12.3 & 0.3 & 1.9 & 0.84 & 3.8 & 54 & $<0.3$ \\
\hline LD-3 & $7 / 20 / 1998$ & & & 8.39 & 8.3 & 0.25 & 15.2 & 29.0 & NA & 119 & NA & 0.5 & 227 & 33.4 & $<1$ & $<0.8$ & $<5$ & 0.4 & 2.1 & 12.2 & 0.3 & 1.6 & 0.82 & 3.6 & 53 & $<0.3$ \\
\hline LD-1 & $8 / 17 / 1998$ & 72.08 & 2041 & 8.31 & 9.7 & 0.26 & 12.5 & 23.9 & $\mathrm{~N}$ & 150 & 2.9 & 0.5 & 237 & 32.8 & $<1$ & $<0.8$ & $<5$ & 0.5 & 2.2 & 11.5 & $<0.3$ & 1.0 & 0.86 & 3.9 & 54 & $<0.3$ \\
\hline LD-2 & 8/17/1998 & & & 8.31 & 9.7 & 0.26 & 12.6 & 24.0 & NA & 14 & 2.9 & 0.6 & 244 & 33.4 & $<1$ & $<0.8$ & $<5$ & 0.5 & 2.2 & 11.7 & $<0.3$ & 0.8 & 0.84 & 3.9 & 55 & $<0.3$ \\
\hline LD-3 & 8/17/1998 & & & 8.32 & 9.7 & 0.27 & 12.5 & 23.9 & NA & 1 & 2.9 & 0.6 & 246 & 33.6 & $<1$ & $<0.8$ & $<5$ & 0.5 & 2.2 & 11.8 & $<0.3$ & 1.0 & 0.89 & 3.7 & 56 & $<0.3$ \\
\hline LD-4 & $8 / 17 / 1998$ & & & & & & & & NA & 130 & 2.9 & 0.5 & 247 & 33.5 & $<1$ & $<0.8$ & $<5$ & 0.5 & 2.2 & 11.7 & $<0.3$ & 0.9 & 0.88 & 3.7 & 56 & $<0.3$ \\
\hline LD-5 & $8 / 17 / 1998$ & & & & & & & & NA & 130 & 2.9 & 0.5 & 245 & 33.3 & $<1$ & $<0.8$ & $<5$ & 0.5 & 2.2 & 11.7 & $<0.3$ & 0.9 & 0.88 & 3.7 & 55 & $<0.3$ \\
\hline LD-6 & 8/17/1998 & & & & & & & & NA & 135 & 2.9 & 0.5 & 243 & 33.8 & $<1$ & $<0.8$ & $<5$ & 0.5 & 2.2 & 11.7 & $<0.3$ & 0.9 & 0.87 & 3.7 & 55 & $<0.3$ \\
\hline LD-7 & $8 / 17 / 1998$ & & & & & & & & NA & 13 & 2.9 & 0.5 & 247 & 33.1 & $<1$ & $<0.8$ & $<5$ & 0.5 & 2.2 & 11.7 & $<0.3$ & 0.7 & 0.87 & 3.9 & 57 & $<0.3$ \\
\hline LD-8 & $8 / 17 / 1998$ & & & & & & & & NA & 12 & 2.9 & 0.5 & 251 & 33.5 & $<1$ & $<0.8$ & $<5$ & 0.5 & 2.2 & 11.7 & $<0.3$ & 0.8 & 0.86 & 4.0 & 56 & $<0.3$ \\
\hline LD-9 & $8 / 17 / 1998$ & & & & & & & & NA & 135 & 2.9 & 0.5 & 245 & 33.7 & $<1$ & $<0.8$ & $<5$ & 0.5 & 2.2 & 11.7 & $<0.3$ & 0.9 & 0.88 & 3.7 & 55 & $<0.3$ \\
\hline LD-10 & $8 / 17 / 1998$ & & & & & & & & NA & 125 & 2.9 & & 242 & 33.7 & $<1$ & $<0.8$ & $<5$ & 0.5 & 2.2 & 11.7 & $<0.3$ & 0.7 & 0.85 & 3.7 & 55 & $<0.3$ \\
\hline
\end{tabular}

\section{Blackfoot River, site "BH"}

\begin{tabular}{|c|c|c|c|c|c|c|c|c|c|c|c|c|c|c|c|c|c|c|c|c|c|c|c|c|c|c|}
\hline BH-1 & $4 / 29 / 1998$ & 78.62 & 2227 & 7.80 & NA & 0.19 & 5.6 & 14.4 & 18.9 & NA & NA & 0.2 & 144 & 21.3 & $<1$ & $<0.8$ & 32 & 0.7 & 1.5 & 10.2 & 3.9 & 1.9 & 13.2 & 5.3 & 74 & 32.6 \\
\hline BH-2 & $4 / 29 / 1998$ & 76.87 & 2177 & 7.80 & NA & 0.19 & & & 17.2 & NA & NA & 0.2 & 144 & 21.0 & $<1$ & $<0.8$ & 34 & 0.7 & 1.5 & 10.1 & 3.9 & 1.9 & 13.3 & 5.4 & 73 & 32.5 \\
\hline $\mathrm{BH}-3$ & $4 / 29 / 1998$ & & & 7.79 & NA & 0.19 & & & 18.2 & NA & NA & 0.2 & 144 & 21.0 & $<1$ & $<0.8$ & 39 & 0.7 & 1.5 & 10.1 & 3.9 & 1.9 & 13.3 & 5.4 & 73 & 30.6 \\
\hline BH-1 & 5/19/1998 & 55.75 & 1579 & 7.86 & 11.7 & 0.21 & 7.6 & 18.2 & 20.2 & NA & NA & 0.2 & 174 & 21.8 & $<1$ & $<0.8$ & 34 & 0.7 & 1.7 & 10.6 & 4.4 & 1.9 & 11.4 & 5.5 & 77 & 24.0 \\
\hline $\mathrm{BH}-2$ & $5 / 19 / 1998$ & 55.17 & 1562 & 7.88 & 11.7 & 0.21 & & & 20.1 & NA & NA & 0.3 & 173 & 21.8 & $<1$ & $<0.8$ & 33 & 0.7 & 1.7 & 10.6 & 4.4 & 1.8 & 11.3 & 5.5 & 76 & 24.1 \\
\hline $\mathrm{BH}-3$ & $5 / 19 / 1998$ & & & 7.87 & 11.8 & 0.21 & & & 20.2 & NA & NA & 0.3 & 173 & 21.6 & $<1$ & $<0.8$ & 32 & 0.7 & 1.7 & 10.6 & 4.4 & 1.9 & 11.4 & 5.5 & 75 & 23.7 \\
\hline BH-1 & $6 / 5 / 1998$ & 84.7 & 2399 & 7.90 & 11.8 & 0.19 & 11.7 & 14.7 & NA & 86 & NA & 0.3 & 163 & 21.3 & $<1$ & $<0.8$ & 31 & 0.6 & 1.6 & 9.7 & 4.9 & 2.3 & 5.77 & 5.4 & 71 & 21.8 \\
\hline BH-2 & $6 / 5 / 1998$ & 85.98 & 2435 & 7.92 & 12.0 & 0.19 & & & NA & 84 & NA & 0.3 & 163 & 21.6 & $<1$ & $<0.8$ & 38 & 0.6 & 1.6 & 9.8 & 4.9 & 2.3 & 5.71 & 5.4 & 72 & 18.5 \\
\hline $\mathrm{BH}-3$ & $6 / 5 / 1998$ & & & 7.90 & 11.9 & 0.19 & & & NA & 64 & NA & 0.3 & 165 & 21.6 & $<1$ & $<0.8$ & 38 & 0.6 & 1.6 & 9.6 & 4.9 & 2.2 & 5.79 & 5.4 & 73 & 21.2 \\
\hline BH-1 & $7 / 20 / 1998$ & 70.89 & 2008 & 8.32 & 7.8 & 0.21 & 18.0 & 22.7 & NA & 94 & NA & 0.5 & 229 & 25.3 & $<1$ & $<0.8$ & 35 & 0.8 & 2.2 & 11.1 & 5.4 & 2.7 & 4.09 & 6.7 & 106 & 5.2 \\
\hline BH-2 & $7 / 20 / 1998$ & & & 8.33 & 7.8 & 0.21 & 18.0 & 22.8 & NA & 91 & NA & 0.5 & 226 & 25.0 & $<1$ & 1.1 & 35 & 0.8 & 2.2 & 11.1 & 5.4 & 2.7 & 4.09 & 6.7 & 105 & 3.1 \\
\hline BH-3 & $7 / 20 / 1998$ & & & 8.33 & 7.8 & 0.21 & 17.9 & 22.8 & NA & 93 & NA & 0.4 & 225 & 24.7 & $<1$ & $<0.8$ & 34 & 0.8 & 2.1 & 11.0 & 5.4 & 2.7 & 4.07 & 6.7 & 103 & 2.7 \\
\hline $\mathrm{BH}-1$ & $8 / 17 / 1998$ & 33.65 & 953 & 8.16 & 9.4 & 0.24 & 11.9 & 18.0 & NA & 100 & 13.3 & 0.4 & 240 & 26.8 & $<1$ & 0.8 & 23 & 0.9 & 2.3 & 11.6 & 2.6 & 2.1 & 4.15 & 6.7 & 114 & 0.9 \\
\hline $\mathrm{BH}-2$ & $8 / 17 / 1998$ & 31.7 & 898 & 8.20 & 9.4 & 0.24 & 11.9 & 18.1 & NA & 105 & 13.4 & 0.4 & 226 & 26.2 & $<1$ & $<0.8$ & 21 & 0.8 & 2.2 & 11.3 & 2.5 & 1.9 & 4.00 & 6.3 & 110 & 2.0 \\
\hline $\mathrm{BH}-3$ & 8/17/1998 & & & 8.18 & 9.4 & 0.24 & 11.8 & 18.1 & NA & 100 & 13.4 & 0.4 & 223 & 26.4 & $<1$ & $<0.8$ & 22 & 0.8 & 2.2 & 11.4 & 2.5 & 1.9 & 3.97 & 6.5 & 108 & 2.0 \\
\hline \multicolumn{27}{|c|}{ Blackfoot River, site "BB" } \\
\hline BB-1 & 4/7/1998 & 37.65 & 1066 & 8.10 & 10.7 & 0.21 & 7.1 & 8.1 & 22.0 & NA & NA & 0.2 & 168 & 25.0 & $<1$ & $<0.8$ & 21 & 0.9 & 2.1 & 11.1 & 4.4 & 2.3 & 11.4 & 5.9 & 125 & 1.5 \\
\hline BB-2 & 4/7/1998 & 34.91 & 989 & 8.12 & 10.7 & 0.21 & 7.2 & & 22.6 & NA & NA & 0.3 & 170 & 24.7 & $<1$ & $<0.8$ & 34 & 0.9 & 2.1 & 11.2 & 4.4 & 2.5 & 11.7 & 6.0 & 126 & 1.7 \\
\hline BB-3 & 4/7/1998 & & & 8.12 & 10.6 & 0.21 & 7.1 & & 21.8 & NA & NA & 0.3 & 172 & 24.8 & $<1$ & $<0.8$ & 29 & 0.9 & 2.0 & 11.1 & 4.4 & 2.3 & 11.7 & 6.0 & 125 & 2.4 \\
\hline BB-1 & $4 / 29 / 1998$ & 71.81 & 2034 & 7.93 & NA & 0.18 & 6.8 & 15.4 & 18.2 & NA & NA & 0.2 & 135 & 20.3 & $<1$ & 0.9 & 23 & 0.7 & 1.7 & 9.4 & 3.1 & 2.2 & 11.9 & 5.5 & 97 & 15.6 \\
\hline BB-2 & $4 / 29 / 1998$ & 76.66 & 2171 & 7.93 & NA & 0.19 & & & 17.5 & NA & NA & 0.2 & 135 & 20.2 & $<1$ & 0.9 & 27 & 0.7 & 1.7 & 9.4 & 3.2 & 2.0 & 11.9 & 5.5 & 96 & 18.9 \\
\hline BB-3 & $4 / 29 / 1998$ & & & 7.92 & NA & 0.18 & & & 17.7 & NA & NA & 0.2 & 135 & 20.0 & $<1$ & 0.9 & 26 & 0.7 & 1.7 & 9.3 & 3.2 & 2.0 & 12.0 & 5.5 & 95 & 18.9 \\
\hline BB-1 & $5 / 19 / 1998$ & 64.27 & 1820 & 7.97 & 11.3 & 0.19 & 8.6 & 18.2 & 18.7 & NA & NA & 0.3 & 162 & 20.2 & $<1$ & $<0.8$ & 30 & 0.7 & 1.8 & 9.7 & 3.4 & 2.2 & 10.3 & 5.8 & 95 & 15.0 \\
\hline BB-2 & $5 / 19 / 1998$ & 62.08 & 1758 & 7.96 & 11.4 & 0.19 & & & 18.6 & NA & NA & 0.3 & 159 & 20.1 & $<1$ & $<0.8$ & 25 & 0.7 & 1.8 & 9.5 & 3.3 & 2.1 & 10.4 & 5.8 & 96 & 13.9 \\
\hline BB-3 & $5 / 19 / 1998$ & & & 7.96 & 11.4 & 0.19 & & & 18.5 & NA & $\mathrm{NA}$ & 0.3 & 158 & 19.8 & $<1$ & $<0.8$ & 25 & 0.7 & 1.8 & 9.4 & 3.3 & 1.9 & 10.4 & 5.8 & 94 & 14.1 \\
\hline BB-1 & $6 / 5 / 1998$ & 85.6 & 24 & 7.8 & 12 & 0.18 & 11.9 & 18.2 & NA & 82 & NA & 0. & 15 & 19 & $<1$ & $<0.8$ & 30 & 0 . & 1. & 8. & 3.9 & 2.5 & 5.1 & 5. & 90 & 11.0 \\
\hline BB-2 & $6 / 5 / 1998$ & 87.41 & 2475 & 7.89 & 12.1 & 0.18 & & & NA & 78 & NA & 0.3 & 153 & 19.9 & $<1$ & $<0.8$ & 31 & 0.6 & 1.7 & 8.8 & 3.9 & 2.6 & 5.2 & 5.7 & 91 & 11.1 \\
\hline BB-3 & $6 / 5 / 1998$ & & & 7.89 & 12.2 & 0.18 & & & NA & 80 & NA & 0.4 & 153 & 20.3 & $<1$ & $<0.8$ & 19 & 0.6 & 1.7 & 8.8 & 3.9 & 2.6 & 5.2 & 5.8 & 93 & 8.5 \\
\hline
\end{tabular}




\begin{tabular}{|c|c|c|c|c|c|c|c|c|c|c|c|c|c|c|c|c|c|c|c|c|c|c|c|c|c|c|}
\hline $\begin{array}{l}\text { SAMPLE } \\
\text { NAME }\end{array}$ & $\begin{array}{l}\text { SAMPLE } \\
\text { DATE }\end{array}$ & $\begin{array}{l}\text { STREAM- } \\
\text { FLOW } \\
\text { (cfs) }\end{array}$ & $\begin{array}{l}\text { STREAM- } \\
\text { FLOW } \\
\text { (L/s) }\end{array}$ & pH & $\begin{array}{l}\text { D.O. } \\
\end{array}$ & $\begin{array}{l}\text { Con- } \\
\text { ductivity } \\
(\mathrm{ms} / \mathrm{cm})\end{array}$ & $\begin{array}{l}\text { Water } \\
\text { Temp } \\
\text { (Cel) }\end{array}$ & $\begin{array}{l}\text { Air } \\
\text { Temp } \\
\text { (Cel). }\end{array}$ & $\begin{array}{l}\text { Inorganic } \\
\text { Carbon }\end{array}$ & $\begin{array}{l}\text { Total } \\
\text { Alkalinity } \\
\text { (mg/L CaC }\end{array}$ & $\begin{array}{l}\text { Sulfate } \\
\left.\mathrm{CO}_{3}\right)\end{array}$ & $(\mu \mathrm{q} / \mathrm{L})$ & $\begin{array}{l}\mathrm{Ba} \\
(\mathrm{g} / \mathrm{L})\end{array}$ & $\begin{array}{l}\mathrm{Ca} \\
(\mathrm{mg} / \mathrm{L})\end{array}$ & $\begin{array}{ll}\mathrm{Cr} \\
(\mu \mathrm{L} / \mathrm{L})\end{array}$ & $\begin{array}{ll}\mathrm{Cu} \\
(\mathrm{g} / \mathrm{L})\end{array}$ & $\mathrm{Fe}$ & $\mathrm{K}$ & Li & $\mathrm{Mg}$ & $\mathrm{Mn}$ & $\mathrm{Na}$ & $\mathrm{s}$ & Si & $\mathrm{Sr}$ & $\begin{array}{l}\mathrm{Zn} \\
(\mu \mathrm{g} / \mathrm{L})\end{array}$ \\
\hline BB-1 & $6 / 29 / 1998$ & 217.99 & 6173 & 7.80 & 10.1 & 0.16 & 15.0 & 25.1 & NA & 77 & $\mathrm{NA}$ & 0.4 & 157 & 19.3 & $<1$ & 1.253 & 12 & 0.6 & 1.7 & 8.1 & 5.9 & 3.0 & 3.3 & 5.6 & 84 & 10.3 \\
\hline BB-2 & $6 / 29 / 1998$ & 212.78 & 6026 & 7.75 & 10.1 & 0.16 & 15.0 & 25.2 & NA & 77 & NA & 0.4 & 159 & 19.6 & $<1$ & 1.121 & 7 & 0.6 & 1.7 & 8.1 & 6.0 & 2.9 & 3.3 & 5.8 & 86 & 7.9 \\
\hline BB-3 & $6 / 29 / 1998$ & & & 7.77 & 10.2 & 0.16 & 15.0 & 25.1 & NA & 73 & NA & 0.4 & 156 & 19.3 & 1.2 & 1.278 & 11 & 0.6 & 1.7 & 8.1 & 5.8 & 3.3 & 3.3 & 5.7 & 84 & 5.7 \\
\hline BB-1 & $7 / 20 / 1998$ & 66.66 & 1888 & 8.34 & 6.9 & 0.21 & 16.8 & 23.9 & NA & 89 & NA & 0.5 & 212 & 23.6 & $<1$ & $<0.8$ & 34 & 0.7 & 2.4 & 10.4 & 4.6 & 3.3 & 3.5 & 7.0 & 129 & 2.1 \\
\hline BB-2 & $7 / 20 / 1998$ & & & 8.34 & 6.9 & 0.20 & 16.9 & 24.1 & NA & 82 & NA & 0.5 & 216 & 23.9 & $<1$ & $<0.8$ & 34 & 0.8 & 2.4 & 10.4 & 4.6 & 3.1 & 3.6 & 7.1 & 133 & 2.5 \\
\hline BB-3 & $7 / 20 / 1998$ & & & 8.35 & 6.9 & 0.21 & 16.7 & 24.1 & NA & 85 & NA & 0.5 & 214 & 24.0 & 1.1 & 1.02 & 32 & 0.8 & 2.5 & 10.5 & 4.6 & 3.2 & 3.5 & 7.0 & 134 & 2.6 \\
\hline BB-1 & 9/4/1998 & 18.83 & 533 & 7.89 & 8.5 & 0.24 & 10.2 & 15.9 & 28.1 & 105 & NA & 0.3 & 229 & 27.3 & $<1$ & $<0.8$ & 17 & 0.9 & 2.8 & 11.5 & 1.3 & 2.2 & 3.5 & 7.3 & 147 & 1.4 \\
\hline BB-2 & $9 / 4 / 1998$ & 20.3 & 575 & 7.86 & 8.5 & 0.24 & 10.2 & 15.9 & 28.0 & 103 & NA & 0.3 & 228 & 27.1 & $<1$ & 1.01 & 18 & 0.9 & 2.7 & 11.5 & 1.3 & 3.4 & 3.7 & 7.1 & 144 & 0.8 \\
\hline BB-3 & 9/4/1998 & & & 7.88 & 8.5 & 0.24 & 10.3 & 15.7 & 27.8 & 107 & NA & 0.4 & 243 & 27.7 & $<1$ & $<0.8$ & 20 & 1.0 & 2.8 & 11.8 & 1.5 & 2.3 & 3.8 & 7.4 & 150 & 0.8 \\
\hline BB-1 & $10 / 6 / 1998$ & 20.87 & 591 & 7.76 & 9.2 & 0.23 & 7.0 & 10.5 & 27.6 & 104 & 12.5 & 0.4 & 227 & 27.6 & $<1$ & $<0.8$ & 15 & 0.9 & 2.7 & 11.7 & 1.5 & 2.3 & 3.9 & 7.1 & 146 & 0.5 \\
\hline BB-2 & $10 / 6 / 1998$ & & & 7.77 & 9.2 & 0.22 & 7.2 & 10.5 & 27.5 & 102 & 12.5 & 0.5 & 222 & 27.0 & $<1$ & $<0.8$ & 15 & 0.8 & 2.6 & 11.5 & 1.5 & 2.2 & 3.8 & 7.0 & 142 & 0.5 \\
\hline BB-3 & 10/6/1998 & & & 7.78 & 9.3 & 0.22 & 7.0 & 10.4 & 27.5 & 107 & 12.5 & 0.5 & 223 & 27.1 & $<1$ & $<0.8$ & 15 & 0.8 & 2.6 & 11.5 & 1.6 & 2.2 & 3.8 & 7.1 & 142 & 0.7 \\
\hline BB-1 & $11 / 7 / 1998$ & 11.27 & 319 & 8.35 & 13.7 & 0.25 & 3.0 & -2.5 & NA & 108 & NA & 0.2 & 221 & 27.2 & $<1$ & $<0.8$ & 15 & 0.8 & 2.6 & 11.9 & 1.3 & 2.3 & 4.1 & 7.3 & 148 & 0.5 \\
\hline BB-2 & $11 / 7 / 1998$ & & & 8.35 & 13.7 & 0.25 & 3.0 & & NA & 102 & NA & 0.2 & 217 & 27.3 & $<1$ & $<0.8$ & 15 & 0.8 & 2.5 & 11.8 & 1.4 & 2.3 & 4.1 & 7.2 & 145 & 0.5 \\
\hline BB-3 & $11 / 7 / 1998$ & & & 8.37 & 13.7 & 0.25 & 3.0 & & NA & 109 & NA & & 226 & 27.5 & $<1$ & $<0.8$ & 15 & 0.9 & 2.6 & 12.0 & 1.4 & 2.4 & 4.2 & 7.4 & 151 & 0.6 \\
\hline BB-1 & $12 / 5 / 1998$ & 10.7 & 303 & 8.17 & NA & 0.24 & 0.0 & & 28 & 11 & $\mathrm{~N}$ & 0.1 & 223 & 28.1 & $<1$ & $<0.8$ & 13 & 0.8 & 2.6 & 12.1 & 2.0 & 2.4 & 4.6 & 7.3 & 147 & 5.4 \\
\hline BB-2 & $12 / 5 / 1998$ & & & 8.17 & NA & 0.25 & & & 27.4 & 110 & NA & 0.1 & 214 & 26.9 & $<1$ & $<0.8$ & 12 & 0.8 & 2.4 & 11.6 & 1.9 & 2.3 & 4.4 & 7.0 & 139 & 5.1 \\
\hline BB-3 & $12 / 5 / 1998$ & & & 8.18 & NA & 0.26 & & & 27.5 & 104 & NA & 0.2 & 221 & 28.1 & $<1$ & $<0.8$ & 12 & 0.8 & 2.5 & 12.1 & 2.0 & 2.5 & 4.6 & 7.3 & 146 & 2.8 \\
\hline \multicolumn{27}{|c|}{ Blackfoot River, site "BC" } \\
\hline BC-1 & 4/7/1998 & 40.33 & 1142 & 8.10 & 10.8 & 0.21 & 6.9 & 8.0 & 22.9 & NA & NA & 0.3 & 186 & 26.1 & 1.01 & $<0.8$ & 27 & 0.9 & 2.2 & 11.5 & 2.0 & 2.3 & 11.3 & 6.1 & 130 & 1.2 \\
\hline $\mathrm{BC}-2$ & 4/7/1998 & 37.27 & 1055 & 8.08 & 10.8 & 0.21 & 6.9 & & 23.0 & NA & NA & 0.3 & 175 & 25.6 & $<1$ & $<0.8$ & 16 & 0.8 & 2.2 & 11.3 & 2.0 & 2.5 & 11.0 & 5.9 & 125 & 1.2 \\
\hline BC-3 & 4/7/1998 & & & 8.09 & 10.8 & 0.21 & 6.9 & & 22.9 & NA & NA & 0.3 & 179 & 25.9 & $<1$ & $<0.8$ & 24 & 0.9 & 2.2 & 11.4 & 2.0 & 2.2 & 11.1 & 5.9 & 130 & 1.1 \\
\hline$B C-1$ & 8 & 79.95 & 2264 & 7.9 & 14.5 & 0. & 8.0 & 17.0 & 18 & NA & NA & 0.2 & 146 & 21 & $<1$ & $<0.8$ & 23 & 0. & 1.8 & 9. & 2.2 & 2.0 & 11.8 & 5.6 & 103 & 23.1 \\
\hline BC-2 & $4 / 29 / 1998$ & 83.7 & 2370 & 7.94 & 15.5 & 0.19 & & & 18.6 & NA & NA & 0.3 & 142 & 21.2 & $<1$ & $<0.8$ & 16 & 0.7 & 1.8 & 9.5 & 2.2 & 2.1 & 11.5 & 5.5 & 100 & 6.3 \\
\hline BC-3 & $4 / 29 / 1998$ & & & 7.92 & & 0.19 & & & 18.3 & NA & NA & 0.3 & 142 & 21.4 & $<1$ & 0.87 & 20 & 0.7 & 1.8 & 9.7 & 2.2 & 2.2 & 11.5 & 5.6 & 101 & 4.1 \\
\hline$B C-1$ & 5/19/1998 & 70.03 & 1983 & 7.91 & 11.6 & 0.20 & 10.0 & 22.6 & 19 & NA & ov & 0.3 & 167 & 21.1 & $<1$ & $<0.8$ & 21 & 0.7 & 2.0 & 9.9 & 2.2 & 2.3 & 10.7 & 5.8 & 100 & 2.7 \\
\hline BC-2 & 5/19/1998 & 66.92 & 1895 & 7.90 & 11.5 & 0.20 & & & 19.5 & NA & NA & 0.3 & 165 & 20.7 & $<1$ & $<0.8$ & 20 & 0.7 & 1.9 & 9.8 & 2.2 & 2.1 & 10.7 & 5.8 & 98 & 9.6 \\
\hline BC-3 & $5 / 19 / 1998$ & & & 7.92 & 11.6 & 0.20 & & & 19.6 & NA & NA & 0.3 & 163 & 20.4 & $<1$ & $<0.8$ & 20 & 0.7 & 1.9 & 9.7 & 2.2 & 2.0 & 10.6 & 5.7 & 96 & 9.7 \\
\hline BC- & $6 /$ & 98.01 & 2776 & 7.80 & 10.8 & 0. & 11.0 & 10.6 & $\mathrm{~N}$ & 96 & & 0. & 16 & & $<1$ & $<0.8$ & 2 & 0. & 1. & 9. & 2.8 & 2.6 & 5.1 & 5.7 & 97 & 13.4 \\
\hline BC-2 & $6 /$ & 99.42 & 2816 & 7.7 & 10.6 & 0.1 & & & $\mathrm{~N}$ & 0. & $\mathrm{~N}$ & 0.3 & 160 & 20. & $<1$ & $<0.8$ & 25 & 0.6 & 1.8 & 9.1 & 2.8 & 2.5 & 5.0 & 5.7 & 94 & 18.8 \\
\hline BC-3 & $6 / 5 / 1998$ & & & 7.82 & 10.8 & 0.19 & & & NA & 82 & NA & 0.3 & 159 & 20.7 & $<1$ & $<0.8$ & 21 & 0.6 & 1.8 & 9.1 & 2.7 & 2.6 & 5.0 & 5.7 & 93 & 17.2 \\
\hline BC- & 8 & 242.31 & 6862 & 7.7 & 10 & & 13 & 26.1 & & 7 & $\mathrm{~N}$ & 0 & 15 & 20 & $<1$ & 1.489 & 10 & 0. & 1. & 8. & 5. & 4.0 & 3.4 & 6.4 & 90 & 6.1 \\
\hline $\mathrm{BC}-2$ & & 249.7 & 7072 & 7.75 & 10.5 & 0.1 & 14.0 & 26.2 & & & & 0. & & 20.0 & 1.7 & 1.036 & 9 & & & 8. & 6.2 & 3.0 & 3.3 & 5.7 & 86 & 9.0 \\
\hline $\mathrm{BC}-3$ & $6 / 29 / 1998$ & & & 7.77 & 10.6 & 0.17 & 14.0 & 26.1 & NA & 75 & NA & 0.3 & 165 & 19.8 & $<1$ & 0.994 & 10 & 0.6 & 1.8 & 8.3 & 6.7 & 2.5 & 3.3 & 5.6 & 87 & 4.6 \\
\hline $\mathrm{BC}$ & 71 & 64.02 & 1813 & 8. & 7.9 & & 1 & 3 & NA & 93 & 1 & 0.5 & & & $<$ & $<$ & 2 & 0.8 & 2. & & 3. & 3.4 & 3 & 7. & 137 & 1.8 \\
\hline & 71 & & & & 7. & & & 30 & NA & & & 0 & & & $<1$ & $<0$ & 23 & 0. & 2. & 10 & 3. & 3. & 3. & 7.0 & 137 & 1.4 \\
\hline $\mathrm{BC}-3$ & $7 / 20 / 1998$ & & & 8.27 & 7.9 & 0.21 & 17.7 & 30.5 & NA & 90 & NA & 0.5 & 218 & 24.8 & $<1$ & $<0.8$ & 25 & 0.8 & 2.5 & 10.6 & 3.3 & 3.2 & 3.7 & 7.0 & 137 & 2.2 \\
\hline BC & & 31.0 & 106 & 8.2 & 9. & & 1 & 22 & & & & 0. & & & $<1$ & $<0$ & 16 & & & 10. & 1.0 & 2.4 & 3.7 & 6.8 & 141 & 0.5 \\
\hline & & 39.04 & 1106 & & 9 & & & 22 & & & & & & & $<1$ & & 16 & & & & & 2.4 & & & 14 & . \\
\hline $\mathrm{BC}-3$ & $8 / 17 / 1998$ & & & 8.28 & 9.7 & 0.24 & 12.4 & 22.1 & NA & 105 & 12.8 & 0.4 & 211 & 25.9 & $<1$ & $<0.8$ & 15 & 0.8 & 2.6 & 10.8 & 1.0 & 2.3 & 3.7 & 6.8 & 139 & 0.5 \\
\hline
\end{tabular}




\begin{tabular}{|c|c|c|c|c|c|c|c|c|c|c|c|c|c|c|c|c|c|c|c|c|c|c|c|c|c|c|}
\hline $\begin{array}{l}\text { SAMPLE } \\
\text { NAME }\end{array}$ & $\begin{array}{l}\text { SAMPLE } \\
\text { DATE }\end{array}$ & $\begin{array}{l}\text { STREAM- } \\
\text { FLOW }\end{array}$ & $\begin{array}{l}\text { STREAM- } \\
\text { FLOW } \\
\end{array}$ & $\mathrm{pH}$ & D.O. & $\begin{array}{l}\text { Con- } \\
\text { ductivity } \\
(\mathrm{mS} / \mathrm{cm})\end{array}$ & $\begin{array}{l}\text { Water } \\
\text { Temp } \\
\text { (Cel) }\end{array}$ & $\begin{array}{l}\text { Air } \\
\text { Temp } \\
\text { (Cel) }\end{array}$ & $\begin{array}{l}\text { Inorganic } \\
\text { Carbon } \\
\text { (mg/L) }\end{array}$ & $\begin{array}{l}\text { Total } \\
\text { Alkalinity } \\
\text { (mg/L CaCC }\end{array}$ & $\begin{array}{l}\text { Sulfate } \\
\left.\mathrm{O}_{3}\right)\end{array}$ & $(40 / 1)$ & $\begin{array}{l}\mathrm{Ba} \\
(\mu \mathrm{g} / \mathrm{L})\end{array}$ & $\begin{array}{l}\mathrm{Ca} \\
(\mathrm{mg} / \mathrm{L})\end{array}$ & $\begin{array}{l}\mathrm{Cr} \\
(\mu \mathrm{g} / \mathrm{L})\end{array}$ & $\begin{array}{l}\mathrm{Cu} \\
(\mu \mathrm{g} / \mathrm{L})\end{array}$ & $\begin{array}{l}\mathrm{Fe} \\
(\mu \mathrm{g} / \mathrm{L})\end{array}$ & $\begin{array}{l}\mathrm{K} \\
(\mathrm{mg} / \mathrm{L})\end{array}$ & $\begin{array}{l}\mathrm{Li} \\
(\mu \mathrm{g} / \mathrm{L})\end{array}$ & $\begin{array}{l}\mathrm{Mg} \\
(\mathrm{mg} / \mathrm{L})\end{array}$ & $\begin{array}{l}\mathrm{Mn} \\
(\mu \mathrm{g} / \mathrm{L})\end{array}$ & $\begin{array}{l}\mathrm{Na} \\
(\mathrm{mg} / \mathrm{L})\end{array}$ & $\begin{array}{l}\mathrm{S} \\
(\mathrm{mg} / \mathrm{L})\end{array}$ & $(\mathrm{mg} / \mathrm{L})$ & $\begin{array}{l}\text { Sr } \\
(\mu \mathrm{g} / \mathrm{L})\end{array}$ & $\begin{array}{l}\mathrm{Zn} \\
(\mu \mathrm{g} / \mathrm{L})\end{array}$ \\
\hline $\mathrm{BC}-2$ & $9 / 4 / 1998$ & 24.64 & 698 & 7.77 & 9.1 & 0.24 & 10.6 & 23.6 & 27.5 & & NA & 0.4 & 230 & 27.0 & $<1$ & $<0.8$ & 11 & 0.9 & 2.8 & 11.3 & 0.8 & 2.3 & 3.9 & 7.2 & 147 & 0.4 \\
\hline $\mathrm{BC}-3$ & 9/4/1998 & & & 7.78 & 9.1 & 0.24 & 10.7 & 23.7 & 27.5 & 103 & NA & 0.4 & 226 & 27.1 & $<1$ & $<0.8$ & 10 & 0.9 & 2.8 & 11.3 & 0.8 & 2.2 & 3.9 & 7.2 & 147 & 0.5 \\
\hline BC-1 & 10/6/1998 & 22.2 & 629 & 7.73 & 9.2 & 0.23 & 6.8 & 11.8 & 27.4 & 104 & 12.8 & 0.4 & 216 & 27.0 & $<1$ & $<0.8$ & 9 & 0.8 & 2.7 & 11.2 & 0.7 & 2.1 & 3.9 & 6.9 & 141 & 0.4 \\
\hline BC-2 & $10 / 6 / 1998$ & & & 7.72 & 9.2 & 0.23 & 6.8 & & 27.7 & 103 & 12.8 & 0.5 & 221 & 27.1 & $<1$ & $<0.8$ & 9 & 0.8 & 2.7 & 11.4 & 0.7 & 2.1 & 3.9 & 7.0 & 143 & 0.7 \\
\hline BC-3 & 10/6/1998 & & & 7.73 & 9.2 & 0.23 & 6.8 & & 27.6 & 99 & 12.7 & 0.5 & 222 & 27.1 & $<1$ & $<0.8$ & 9 & 0.8 & 2.7 & 11.4 & 0.7 & 2.1 & 3.9 & 7.0 & 143 & 0.7 \\
\hline BC-1 & $11 / 7 / 1998$ & 16.6 & 470 & 8.02 & 12.8 & 0.25 & 4.2 & 1.0 & NA & 108 & NA & 0.2 & 221 & 27.6 & $<1$ & $<0.8$ & 8 & 0.8 & 2.6 & 11.8 & 0.4 & 2.3 & 4.2 & 7.3 & 148 & 0.5 \\
\hline BC-2 & $11 / 7 / 1998$ & 16.97 & 481 & 8.02 & 12.8 & 0.25 & 4.2 & & NA & 103 & NA & 0.2 & 221 & 27.4 & $<1$ & $<0.8$ & 8 & 0.8 & 2.6 & 11.7 & 0.5 & 2.3 & 4.2 & 7.3 & 148 & 1.0 \\
\hline $\mathrm{BC}-3$ & $11 / 7 / 1998$ & & & 8.02 & 12.8 & 0.25 & 4.0 & & NA & 103 & NA & 0.2 & 224 & 27.4 & $<1$ & $<0.8$ & 9 & 0.8 & 2.6 & 11.7 & 0.5 & 2.4 & 4.2 & 7.3 & 149 & 0.9 \\
\hline \multicolumn{27}{|c|}{ Hogum Creek, site "HC" } \\
\hline HC-1 & 4/29/1998 & 12.83 & 363 & 7.40 & NA & 0.11 & 3.3 & 11.4 & 13.9 & NA & NA & 0.5 & 85 & 12.6 & $<1$ & $<0.8$ & 33 & 0.7 & 3.0 & 4.2 & 3.8 & 4.4 & 2.9 & 7.2 & 267 & $<0.3$ \\
\hline $\mathrm{HC}-2$ & 4/29/1998 & 12.88 & 365 & 7.41 & NA & 0.11 & & & 13.2 & NA & NA & 0.5 & 82 & 12.4 & $<1$ & $<0.8$ & 25 & 0.7 & 3.0 & 4.1 & 3.6 & 4.8 & 2.9 & 7.2 & 261 & $<0.3$ \\
\hline $\mathrm{HC}-3$ & 4/29/1998 & & & 7.39 & NA & 0.11 & & & 13.8 & NA & NA & 0.5 & 82 & 12.5 & $<1$ & $<0.8$ & 26 & 0.7 & 3.0 & 4.1 & 3.6 & 4.8 & 3.0 & 7.2 & 265 & $<0.3$ \\
\hline HC-1 & $5 / 19 /$ & 7.51 & 213 & 7.35 & 11.6 & 0.10 & 4.5 & 16.1 & 10.7 & NA & NA & 0.5 & 78 & 10.2 & $<1$ & $<0.8$ & 34 & 0.7 & 2.8 & 3.6 & 4.0 & 4.3 & 2.6 & 8.0 & 226 & $<0.3$ \\
\hline $\mathrm{HC}-2$ & $5 / 19 / 1998$ & 8.16 & 231 & 7.36 & 11.6 & 0.10 & & & 11.0 & NA & NA & & 80 & 10.2 & $<1$ & $<0.8$ & 40 & 0.7 & 2.8 & 3.6 & 4.2 & 4.1 & 2.5 & 8.1 & 226 & $<0.3$ \\
\hline $\mathrm{HC}-3$ & $5 / 19 / 1998$ & & & 7.35 & 11.7 & 0.10 & & & 10.8 & NA & NA & 0.5 & 80 & 10.0 & $<1$ & $<0.8$ & 35 & 0.7 & 2.8 & 3.6 & 4.3 & 4.1 & 2.5 & 8.1 & 222 & $<0.3$ \\
\hline HC-1 & 6/5/1998 & 13.84 & 392 & 7.38 & 11.9 & 0.10 & 7.5 & 15.6 & NA & 54 & NA & 0.6 & 82 & 9.9 & $<1$ & $<0.8$ & 25 & 0.6 & 2.8 & 3.4 & 3.2 & 4.2 & 1.1 & 8.0 & 222 & $<0.3$ \\
\hline $\mathrm{HC}-2$ & $6 / 5 / 1998$ & 15.01 & 425 & 7.41 & 11.8 & 0.10 & & & NA & 50 & NA & 0.6 & 87 & 10.1 & $<1$ & $<0.8$ & 27 & 0.6 & 2.8 & 3.5 & 3.3 & 3.8 & 1.1 & 8.1 & 227 & $<0.3$ \\
\hline $\mathrm{HC}-3$ & 6/5/1998 & & & 7.40 & 11.8 & 0.09 & & & NA & 54 & NA & 0.6 & 85 & 10.0 & $<1$ & $<0.8$ & 20 & 0.6 & 2.7 & 3.4 & 3.2 & 4.0 & 1.1 & 8.0 & 226 & $<0.3$ \\
\hline HC-1 & $7 / 20 / 1998$ & 8.15 & 231 & 8.04 & 7.7 & 0.13 & 15.9 & 23.3 & NA & 61 & NA & 0.8 & 120 & 15.0 & $<1$ & $<0.8$ & 31 & 0.8 & 3.7 & 5.0 & 5.8 & 6.1 & 1.2 & 9.8 & 334 & $<0.3$ \\
\hline $\mathrm{HC}-2$ & $7 / 20 / 1998$ & & & 8.06 & 7.7 & 0.1 & 15.9 & 23.3 & NA & 61 & NA & 0.8 & 11 & 14.6 & $<1$ & $<0.8$ & 52 & 0.8 & 3.6 & 4.8 & 6.1 & 5.2 & 1.1 & 9.3 & 327 & $<0.3$ \\
\hline $\mathrm{HC}-3$ & $7 / 20 / 1998$ & & & 8.04 & 7.7 & 0.13 & 15.9 & 23.3 & NA & 60 & NA & 0.8 & 121 & 15.2 & $<1$ & $<0.8$ & 41 & 0.8 & 3.8 & 5.0 & 6.1 & 5.9 & 1.2 & 9.8 & 338 & $<0.3$ \\
\hline HC-1 & 8/17/1998 & 2.44 & 69 & 7.79 & 8.7 & 0. & 11.9 & 14.9 & NA & 80 & 4.9 & 1.1 & 138 & 18.9 & $<1$ & $<0.8$ & 168 & 0.9 & 4.4 & 6.2 & 10.9 & 4.6 & 1.4 & 9.6 & 416 & $<0.3$ \\
\hline $\mathrm{HC}-2$ & $8 / 17 / 1998$ & 2.44 & 69 & 7.81 & 8.7 & 0.17 & 12.0 & 14.8 & NA & & & & & & & & & & & & & & & & & \\
\hline \multirow[t]{2}{*}{$\mathrm{HC}-3$} & $8 / 17 / 1998$ & 3.07 & 87 & 7.80 & 8.7 & 0.17 & 12.0 & 14.7 & NA & & & & & & & & & & & & & & & & & \\
\hline & & 3.09 & 88 & & & & & & & & & & & & & & & & & & & & & & & \\
\hline
\end{tabular}




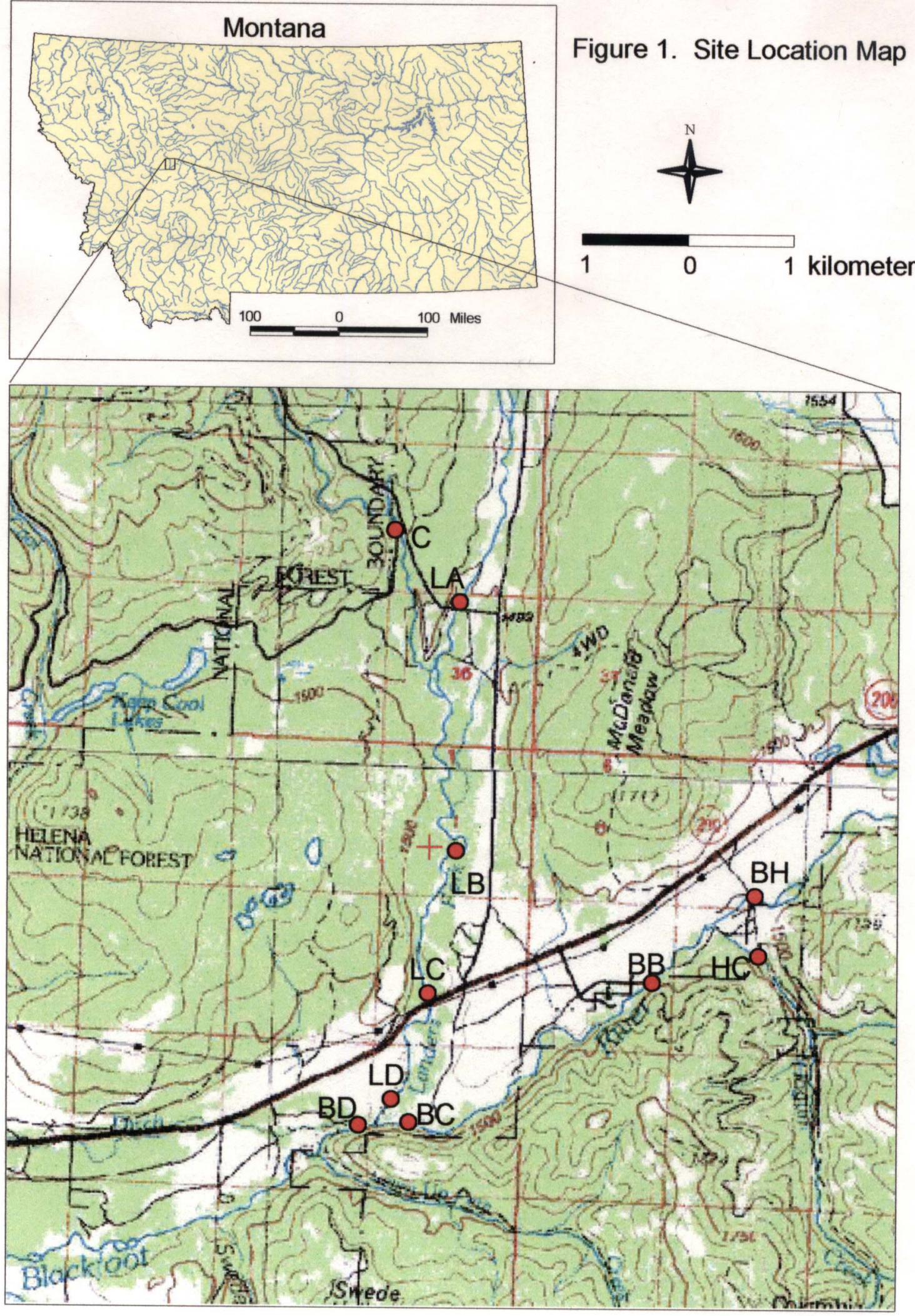


Figures 2a-2h: Streamflow vs. concentrations at Copper Creek, SITE "C"
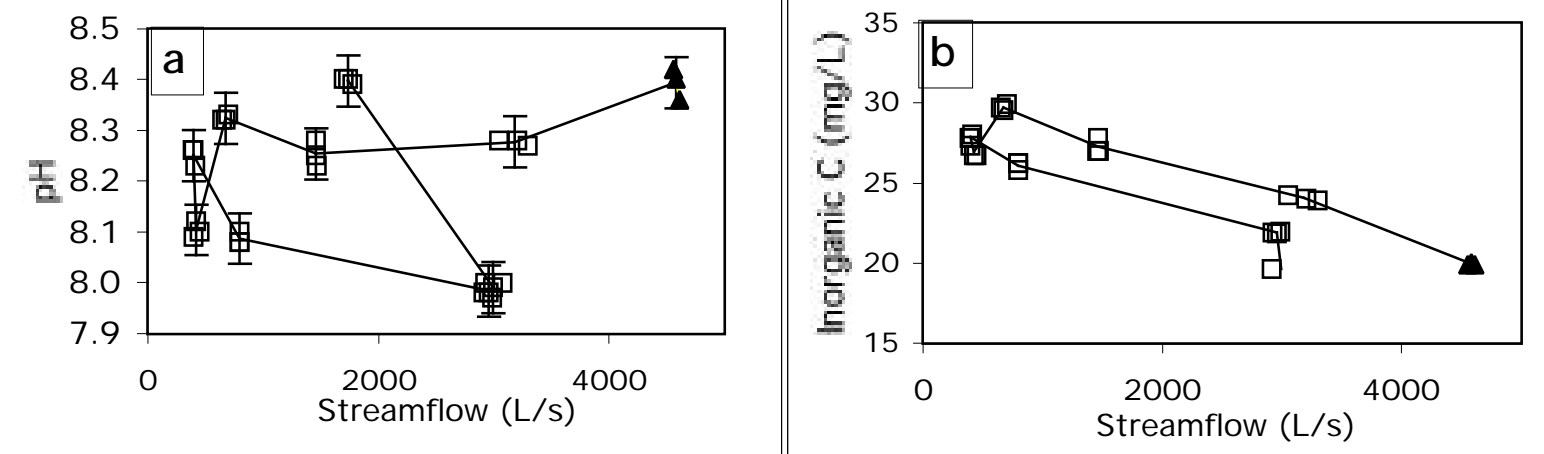

(Triangles indicate first sampling date, 7/3/97)
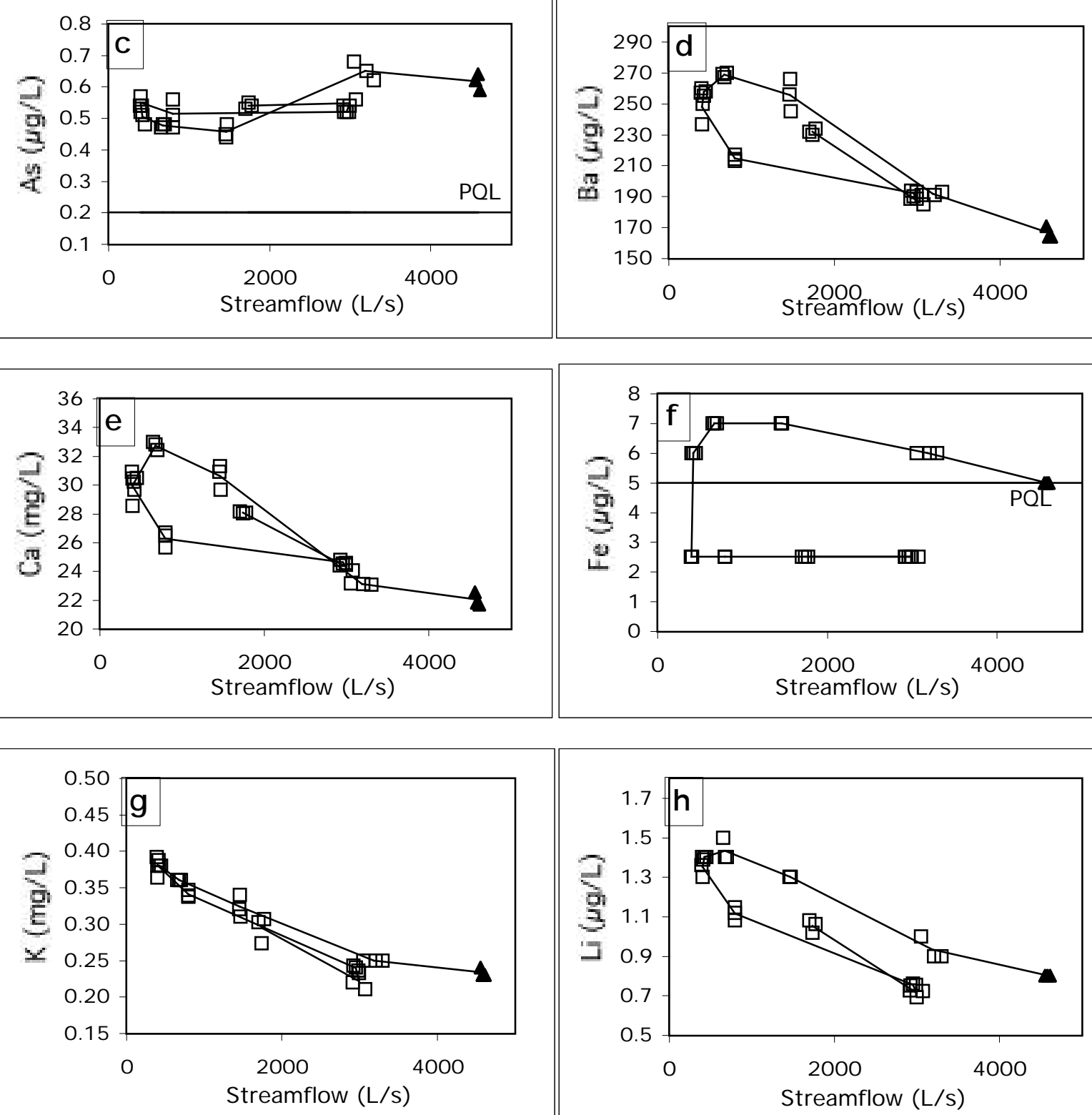
Figures 2i-2n: Streamflow vs. concentrations at Copper Creek, SITE "C"
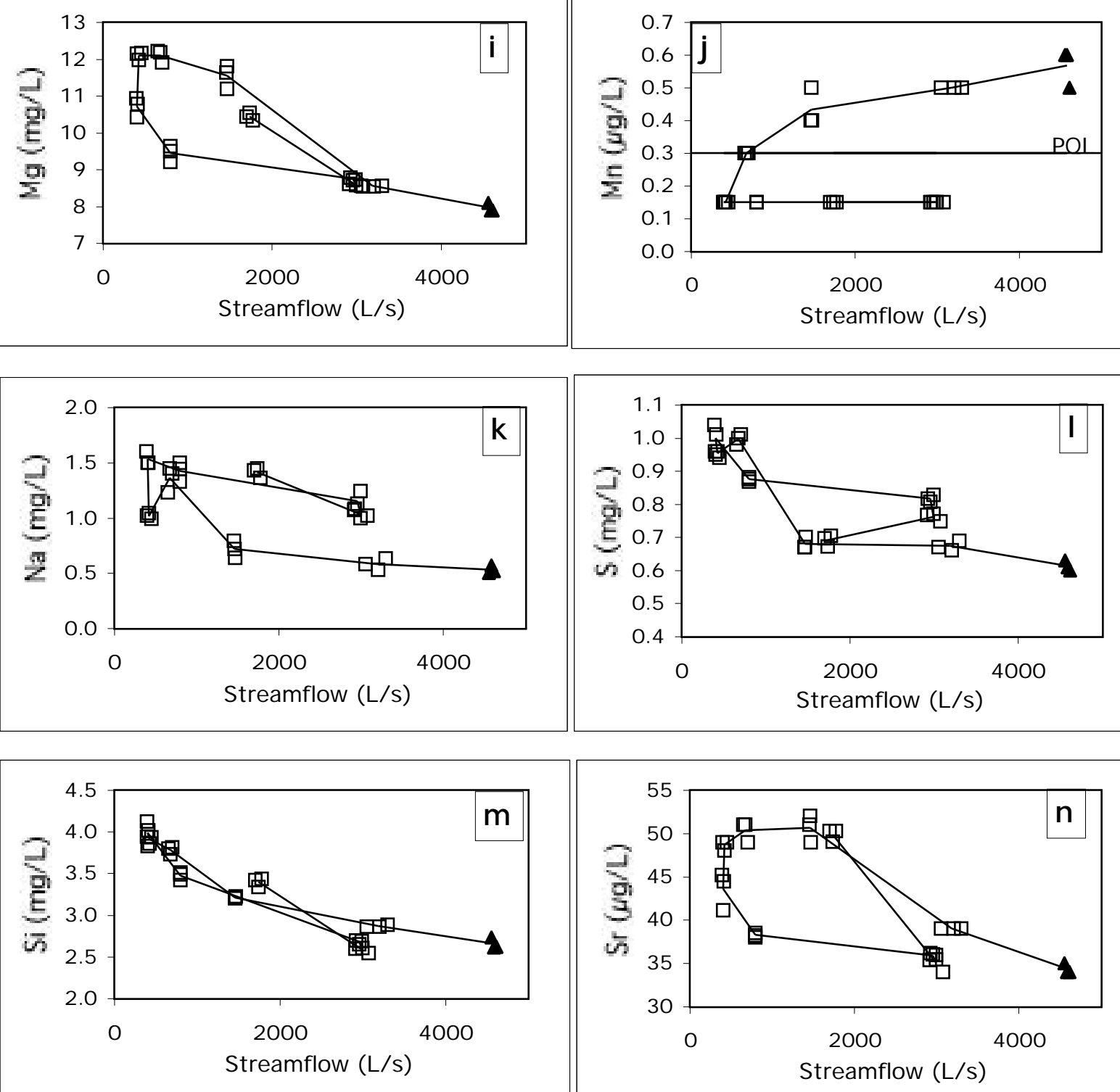
Figures 3a-3h: Trends over time at Copper Creek, Site "C"
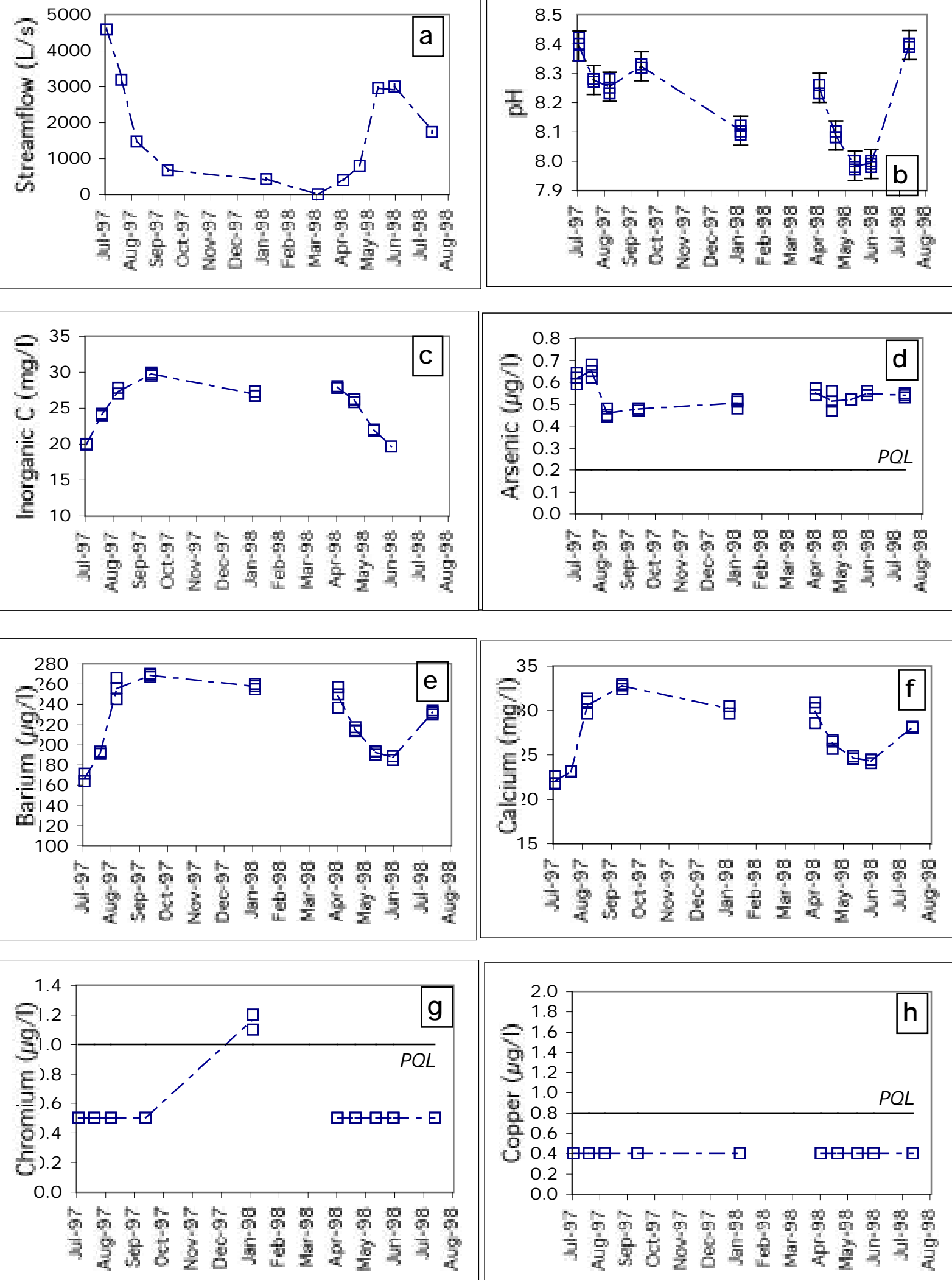
Figures 3i-3p: Trends over time at Copper Creek, Site "C"
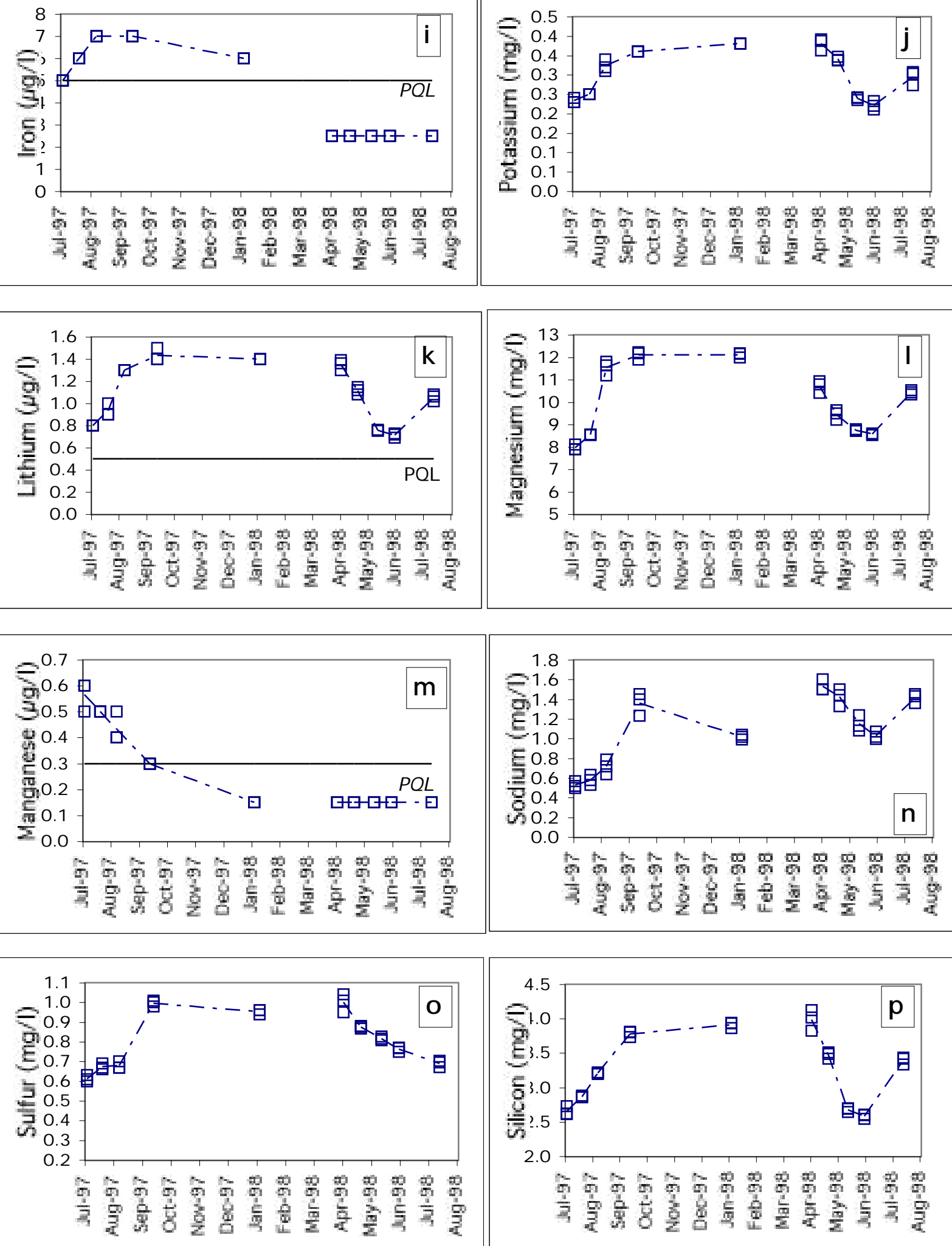
Figures 3q-3r: Trends over time at Copper Creek, Site "C"
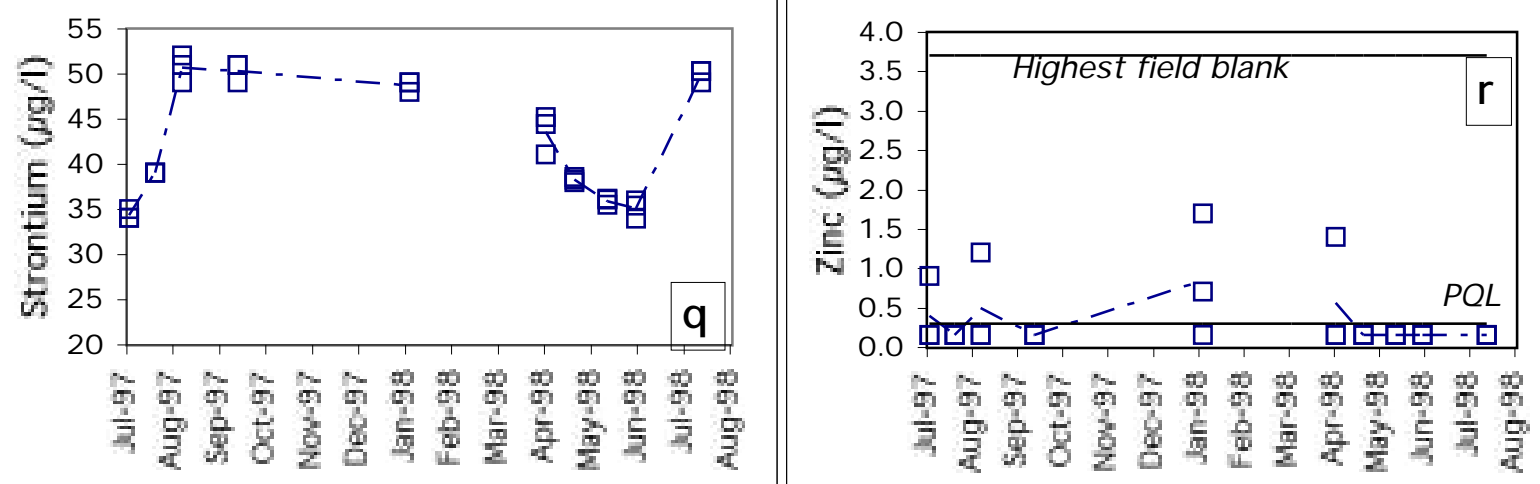

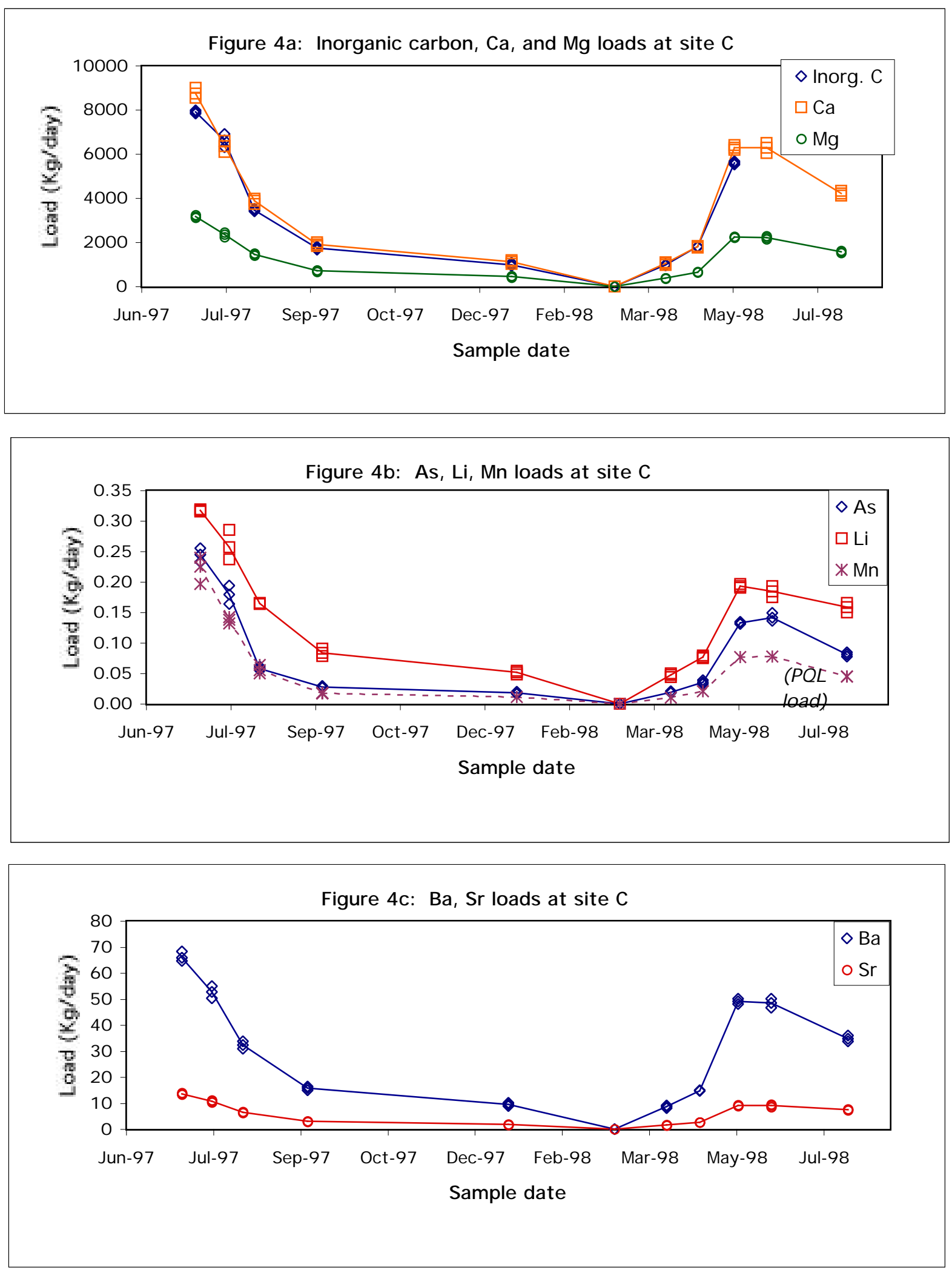
Figure 4d: Fe load at site C

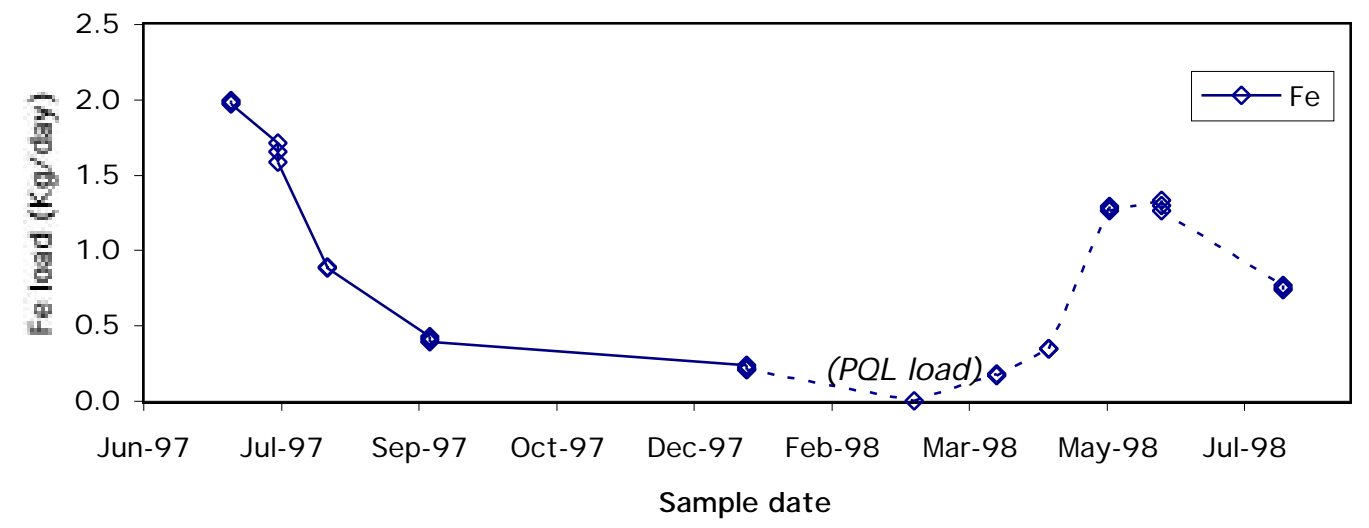

Figure 4 e: $\mathrm{K}, \mathrm{Na}, \mathrm{S}, \mathrm{Si}$ loads at site $\mathrm{C}$

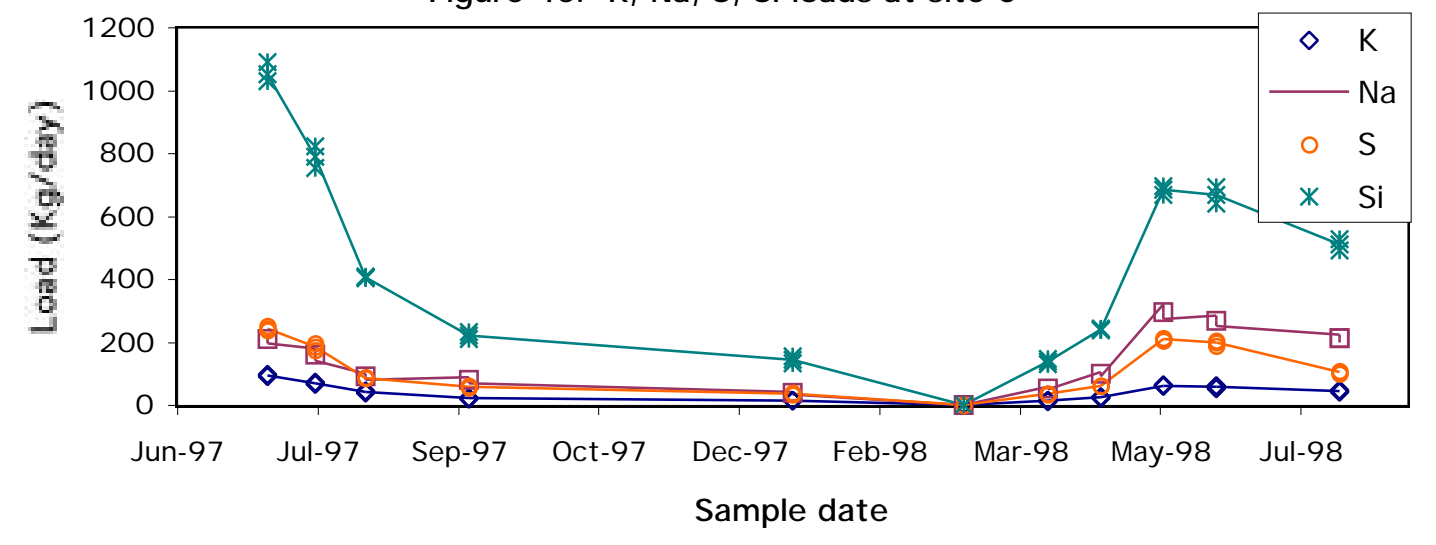


Figures 5a-5h: Streamflow vs. concentrations at Landers Fork site "LA"
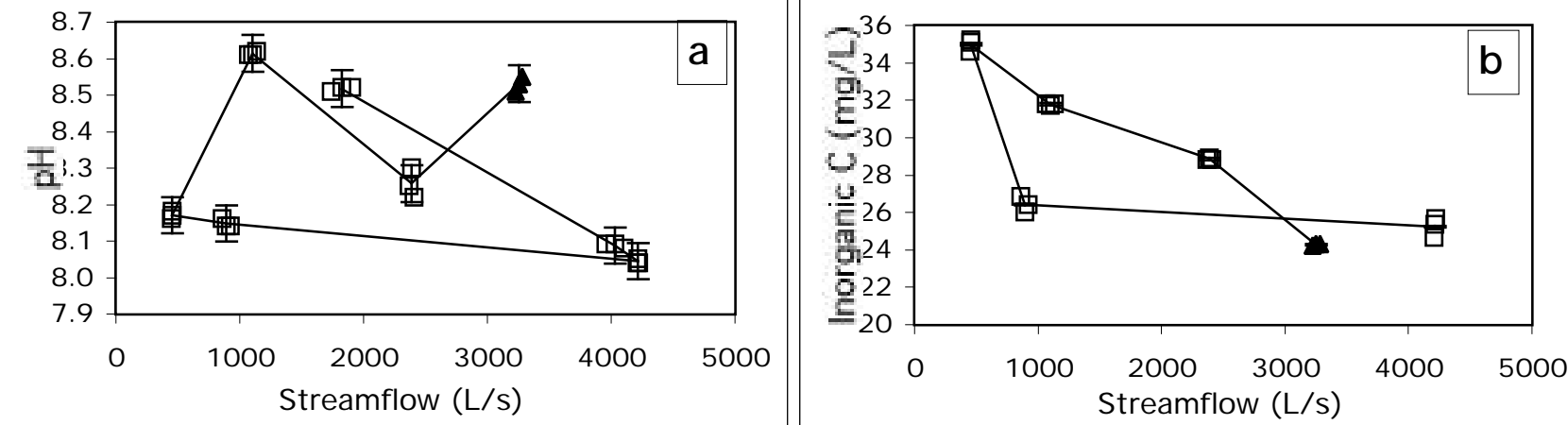

(Triangels indicated first sampling date, 7/3/97)
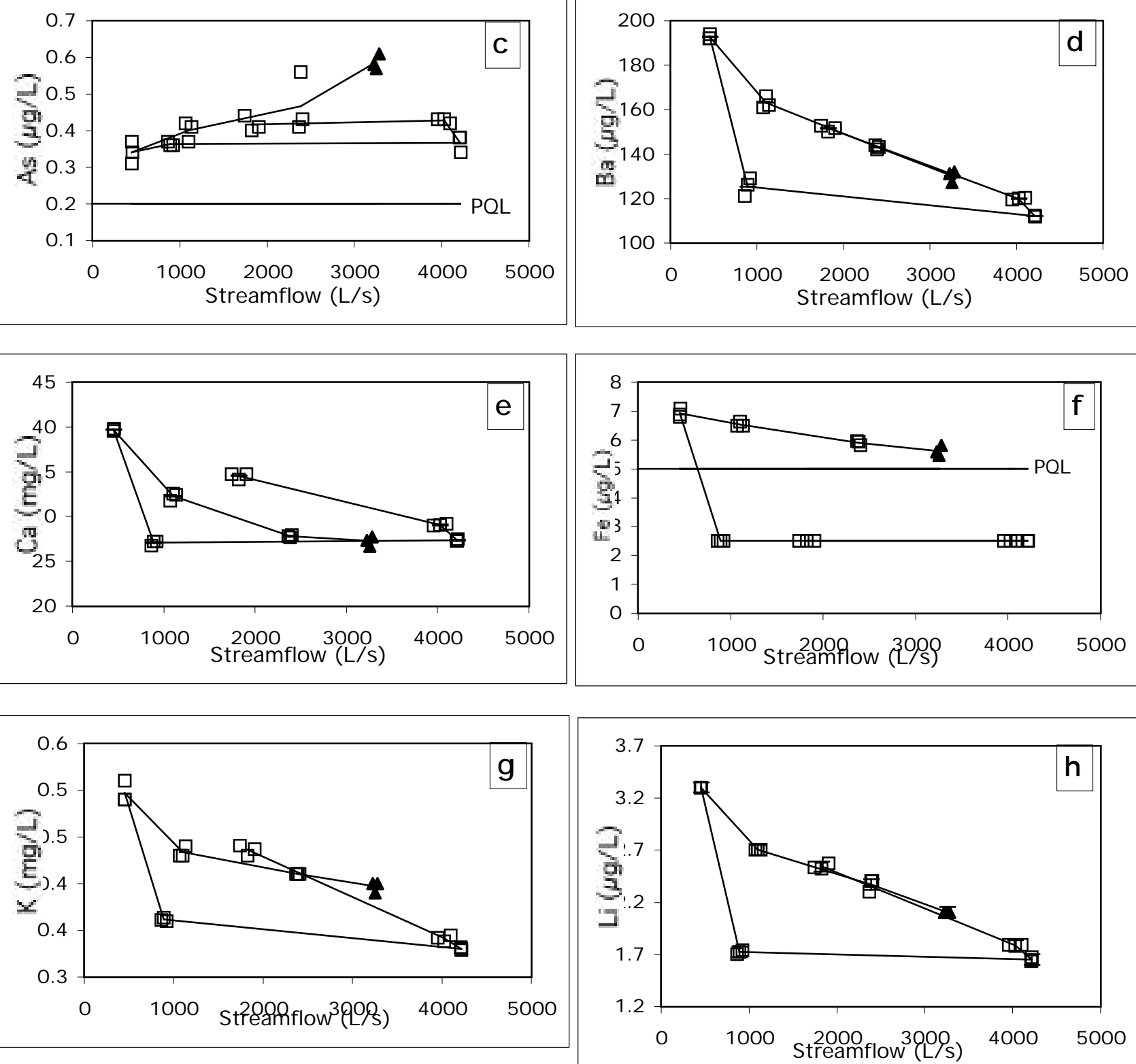
Figures 5i-5n: Streamflow vs. concentrations at Landers Fork site "LA"
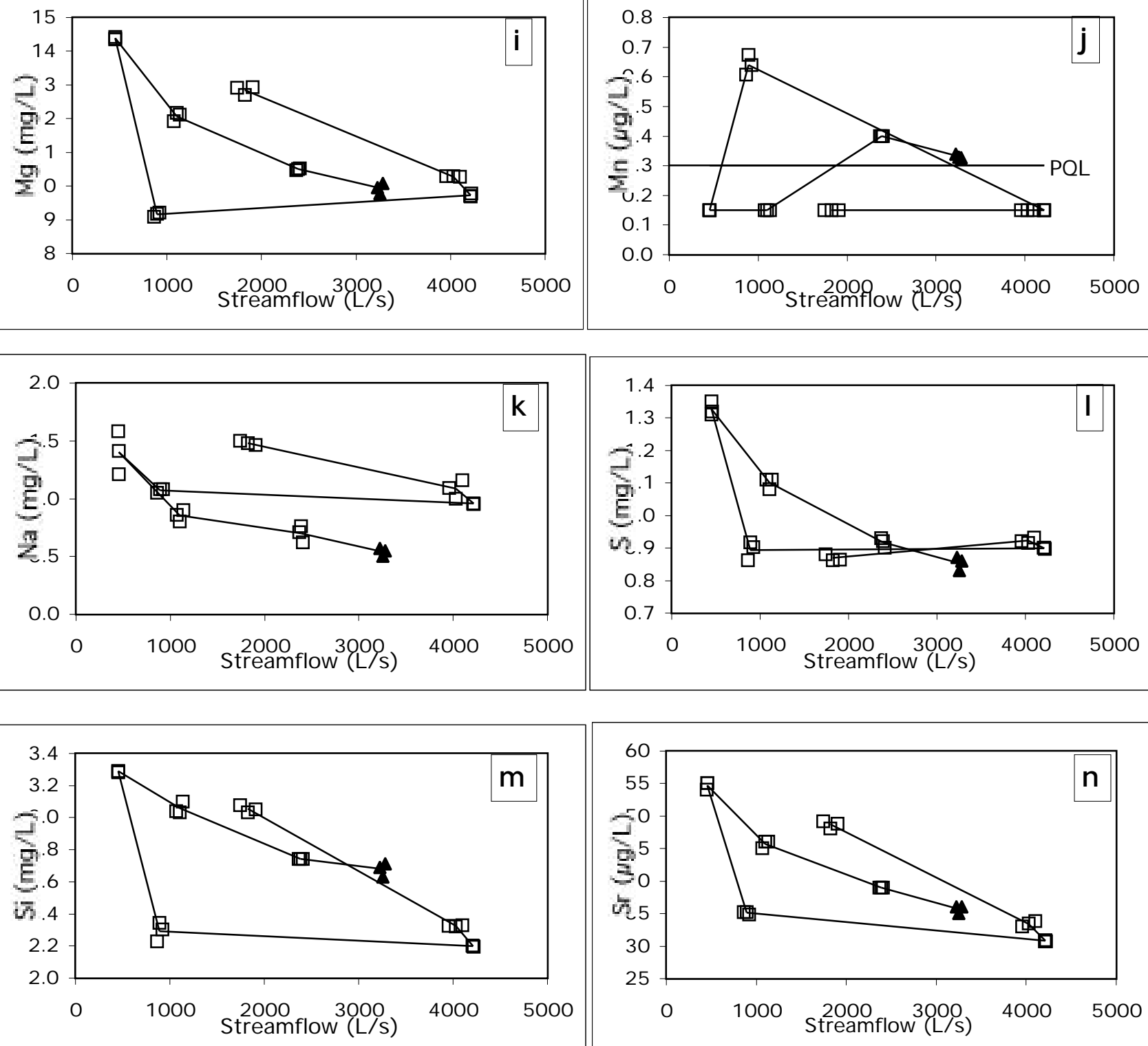
Figure 6a-6h: Trends over time at Landers Fork site "LA"
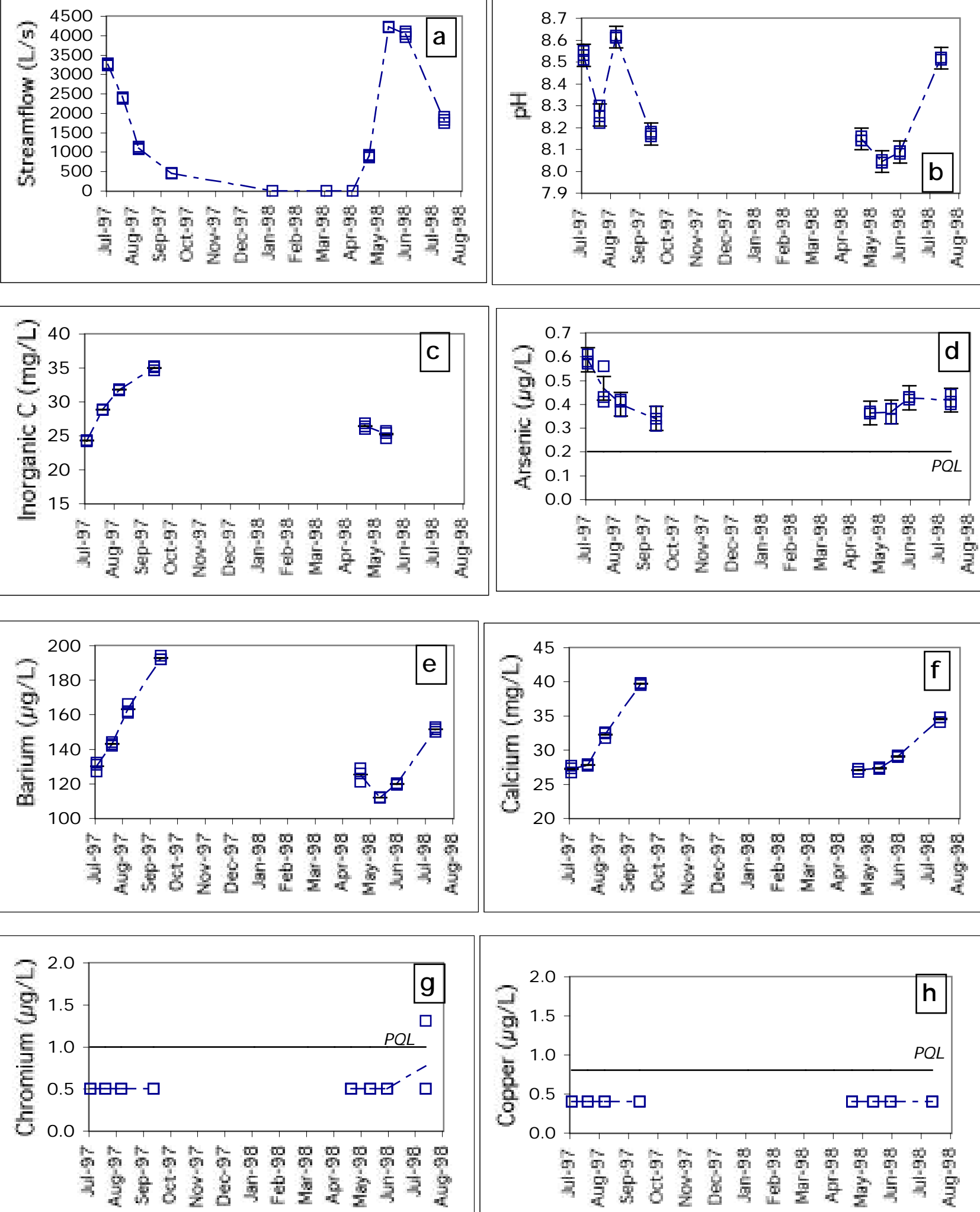
Figure 6i-6p: Trends over time at Landers Fork site "LA"
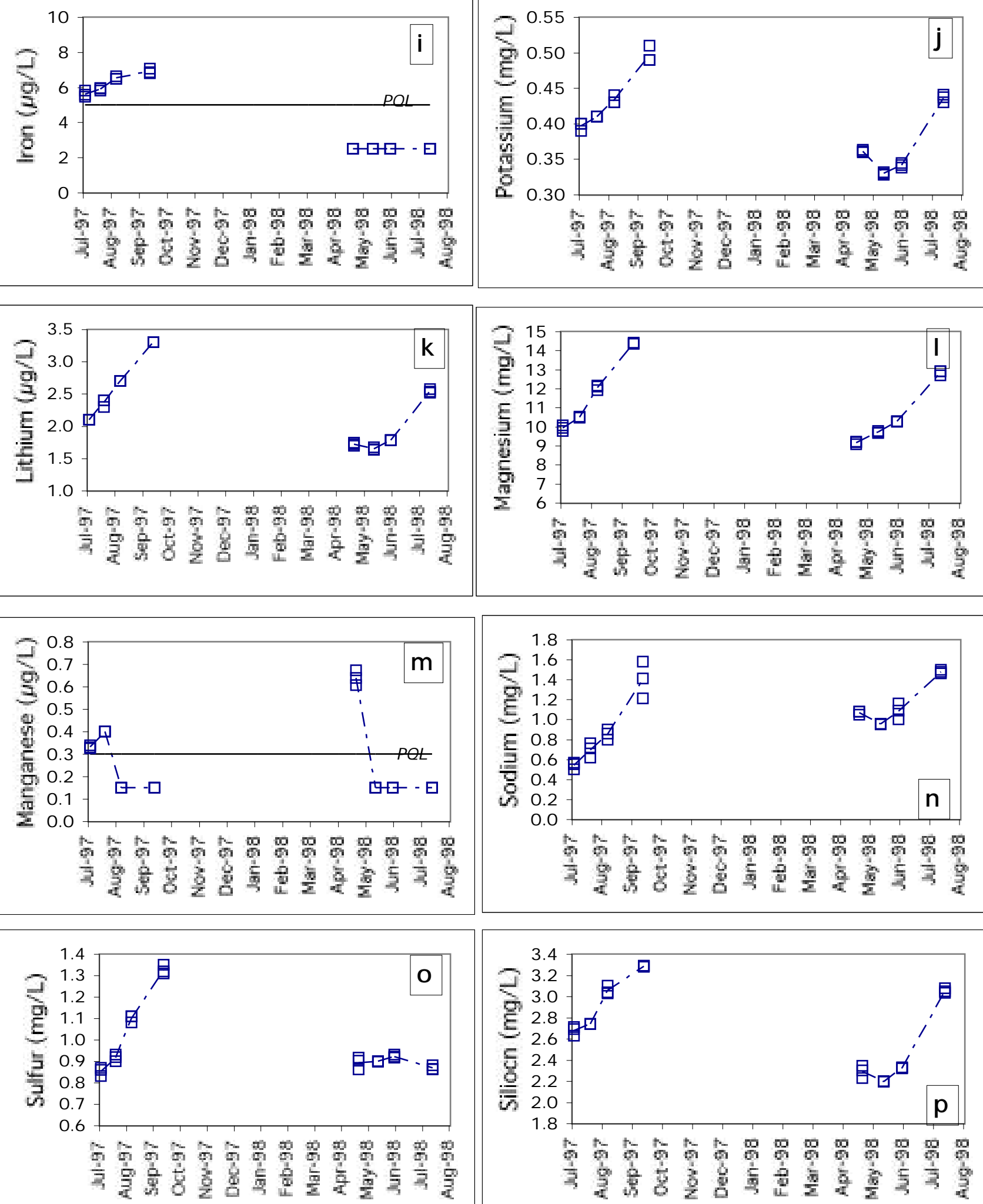
Figure 6q-6r: Trends over time at Landers Fork site "LA"
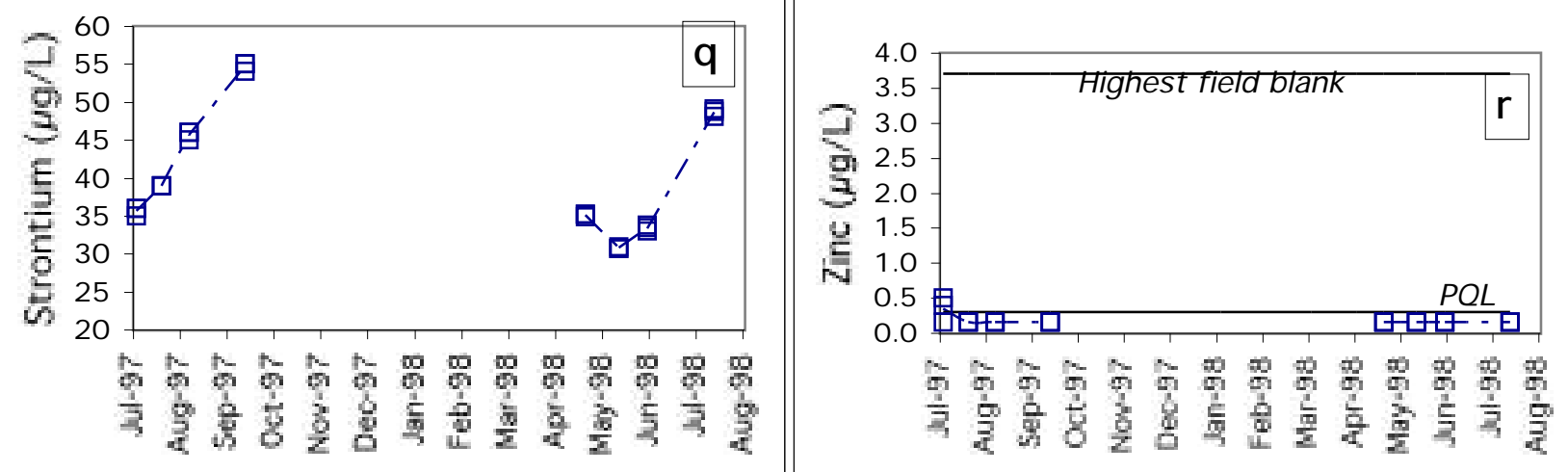
Figure 7a: Inorganic carbon, $\mathrm{Ca}$, and Mg loads at site LA

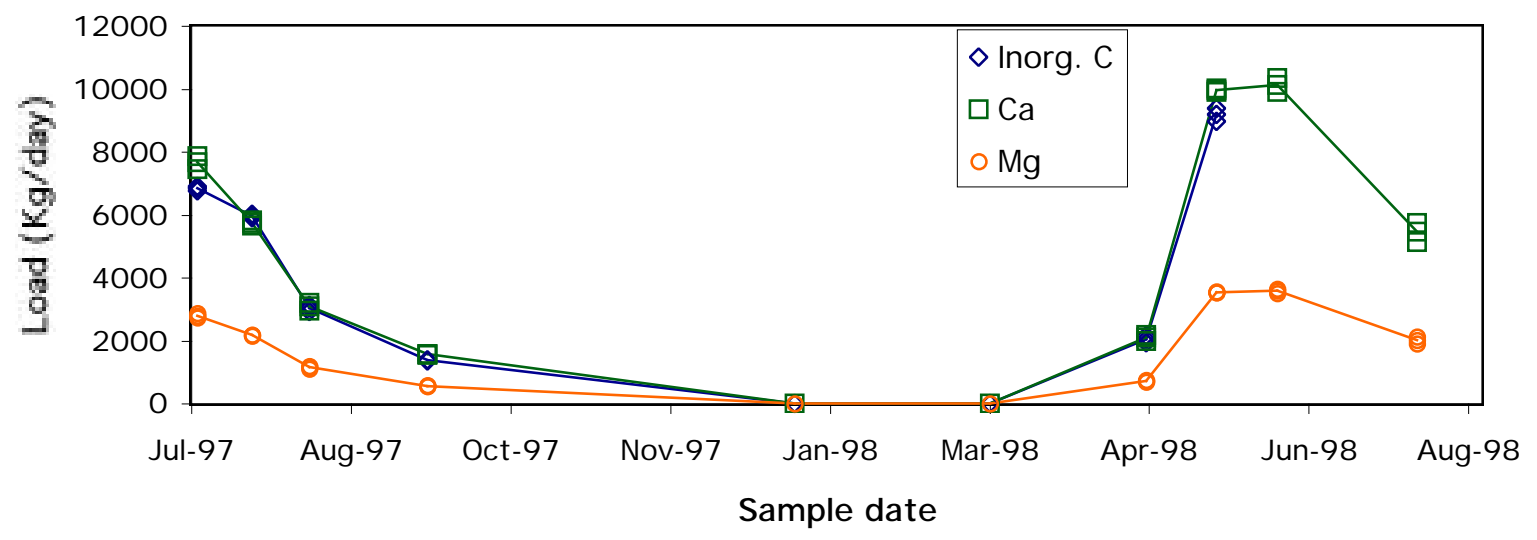

Figure $7 \mathrm{~b}$ : As and Mn loads at site LA

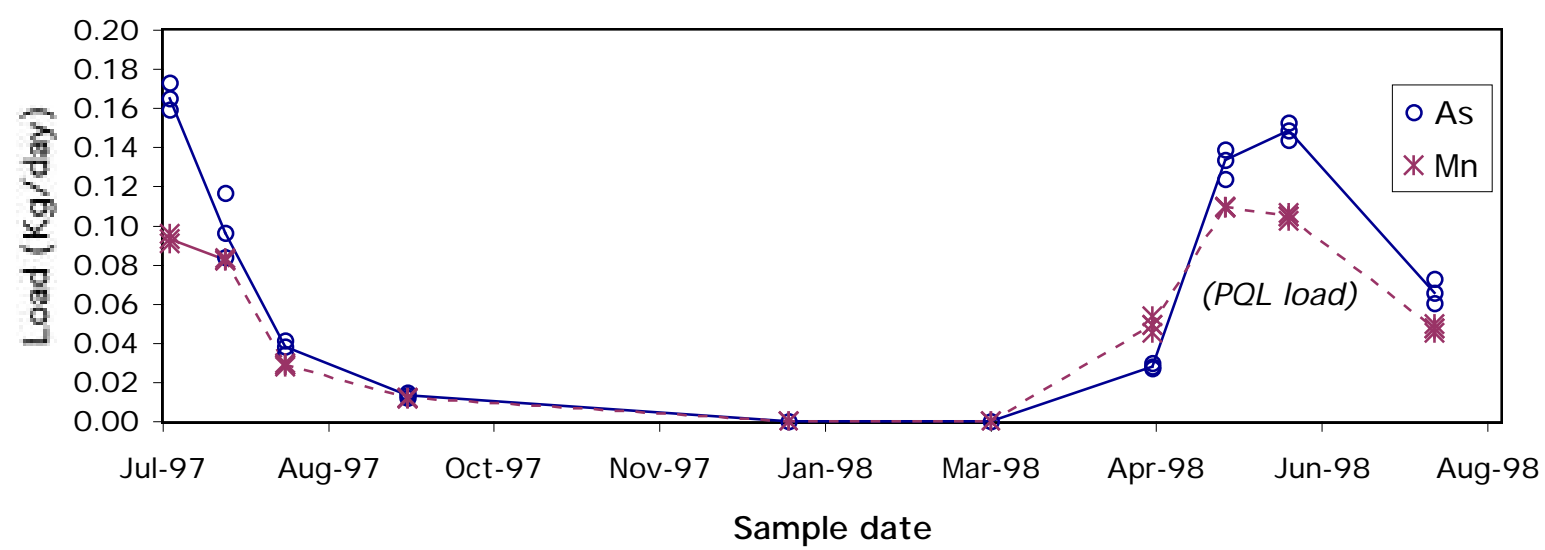

Figure $7 \mathrm{c}: \mathrm{S}, \mathrm{Si}$, and $\mathrm{Na}$ loads at site LA

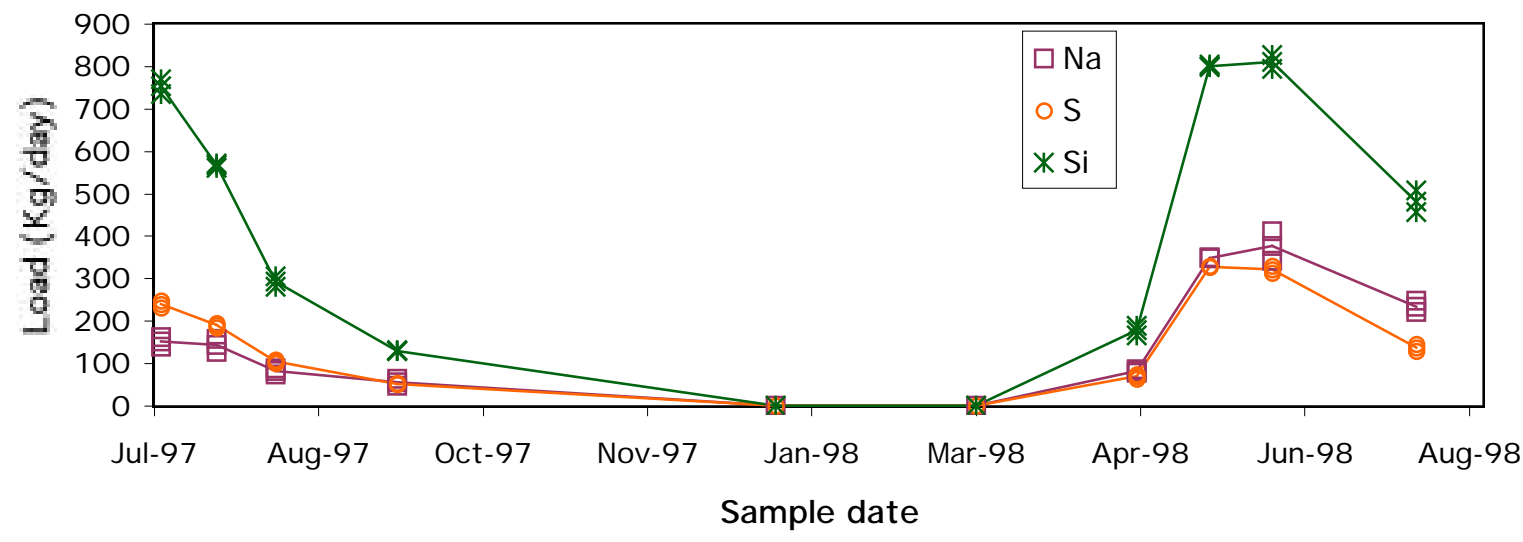


Figure $7 \mathrm{~d}$ : Fe and Li loads at site LA

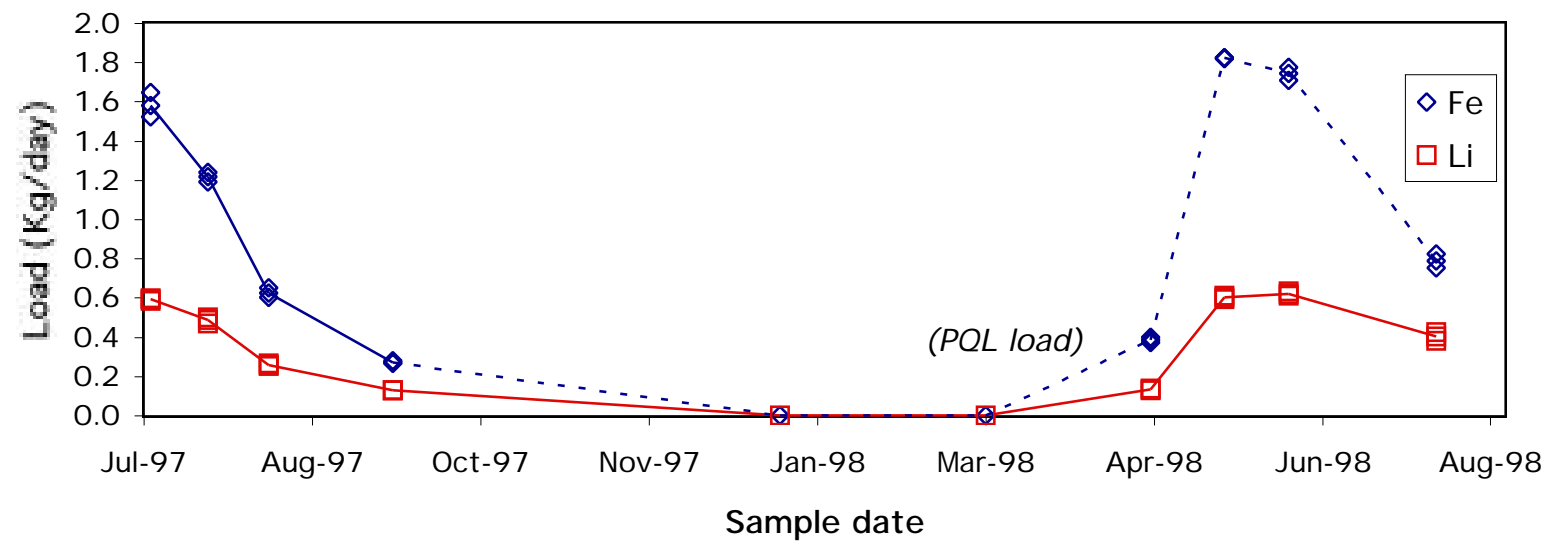

Figure 7e: $\mathrm{Ba}, \mathrm{K}$, and Sr loads at site LA

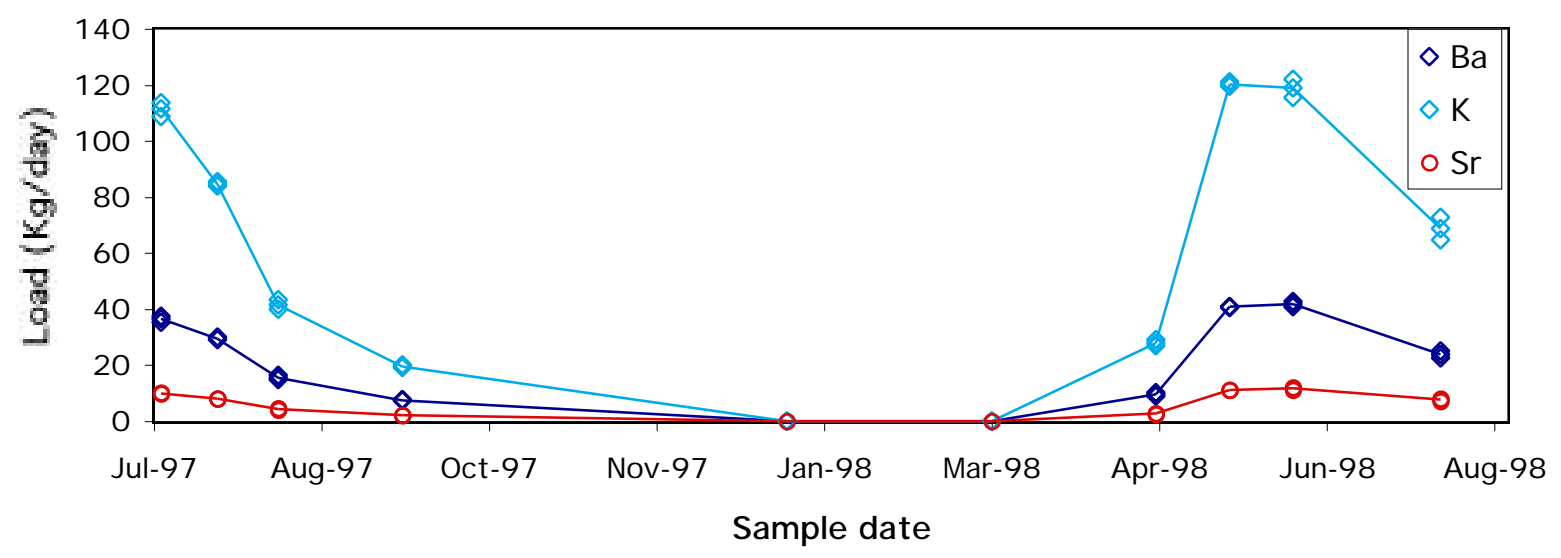


Figures 8a-8h: Streamflow versus concentrations at Landers Fork site "LB"
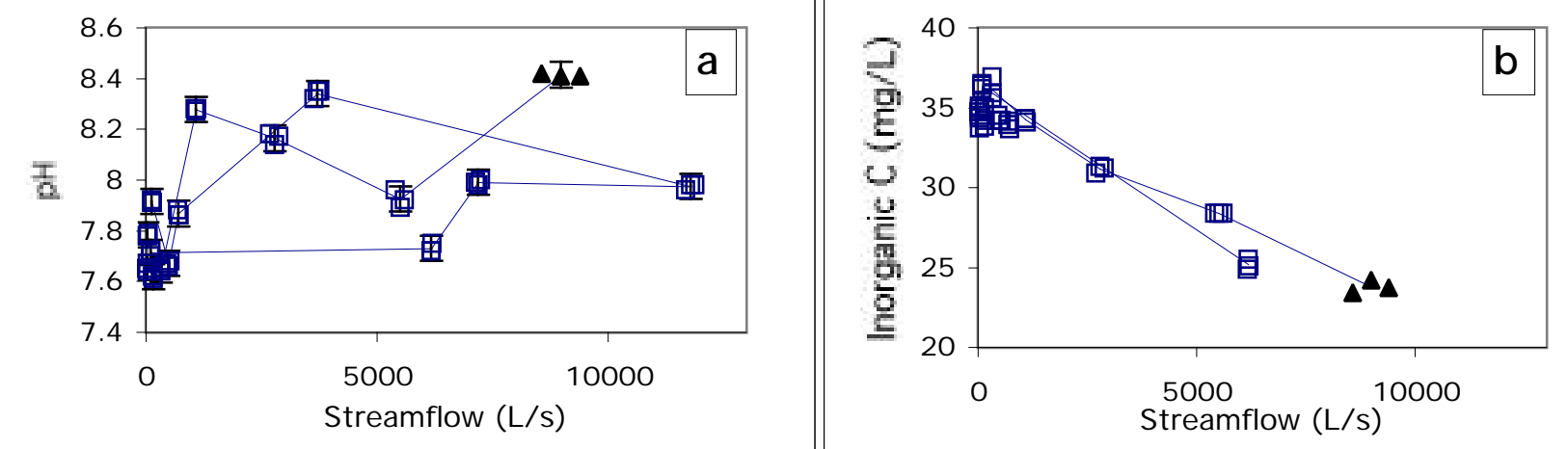

(Triangles indicate first sampling date, 7/3/97)
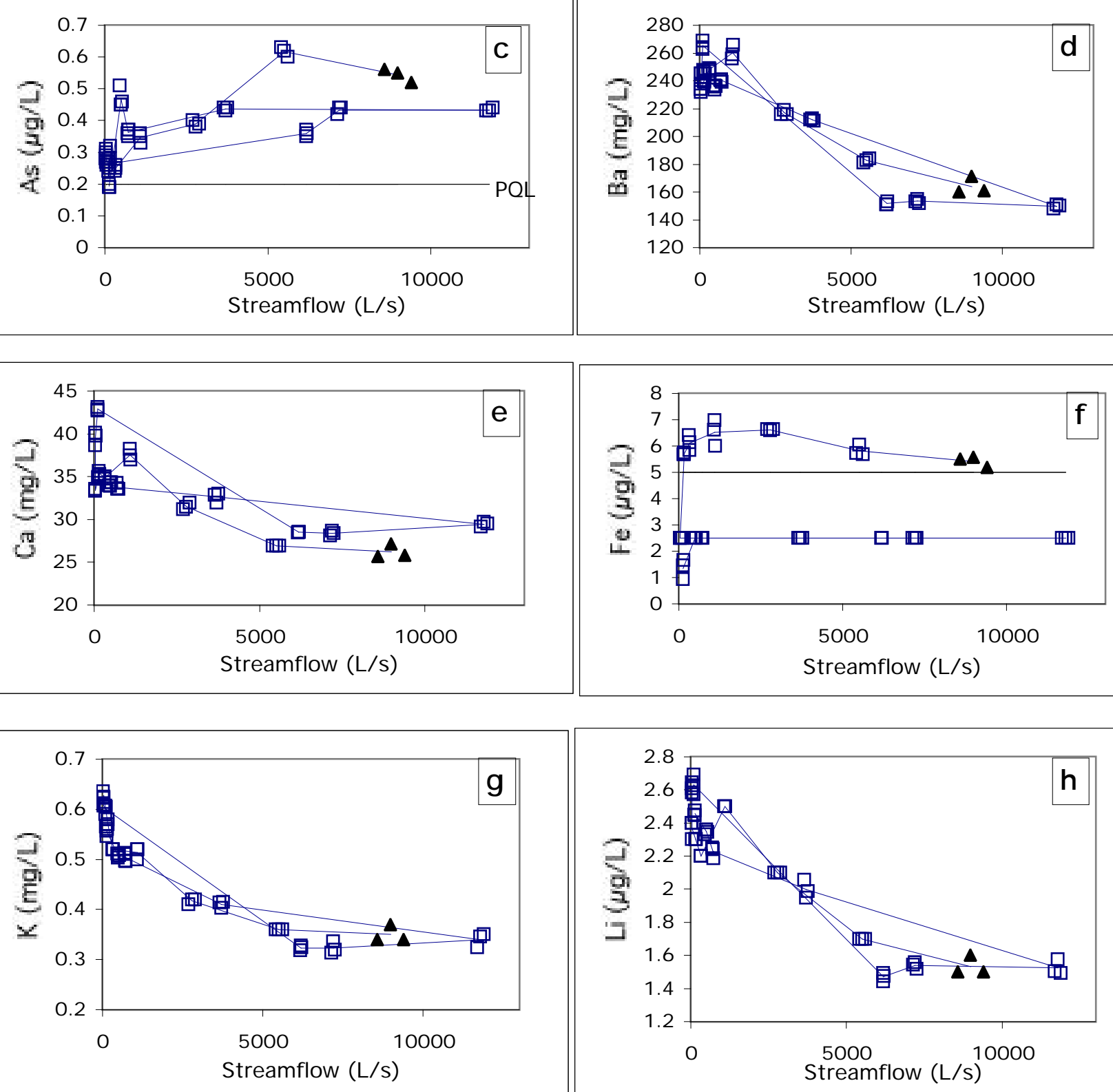
Figures 8i-8n: Streamflow versus concentrations at Landers Fork site "LB"
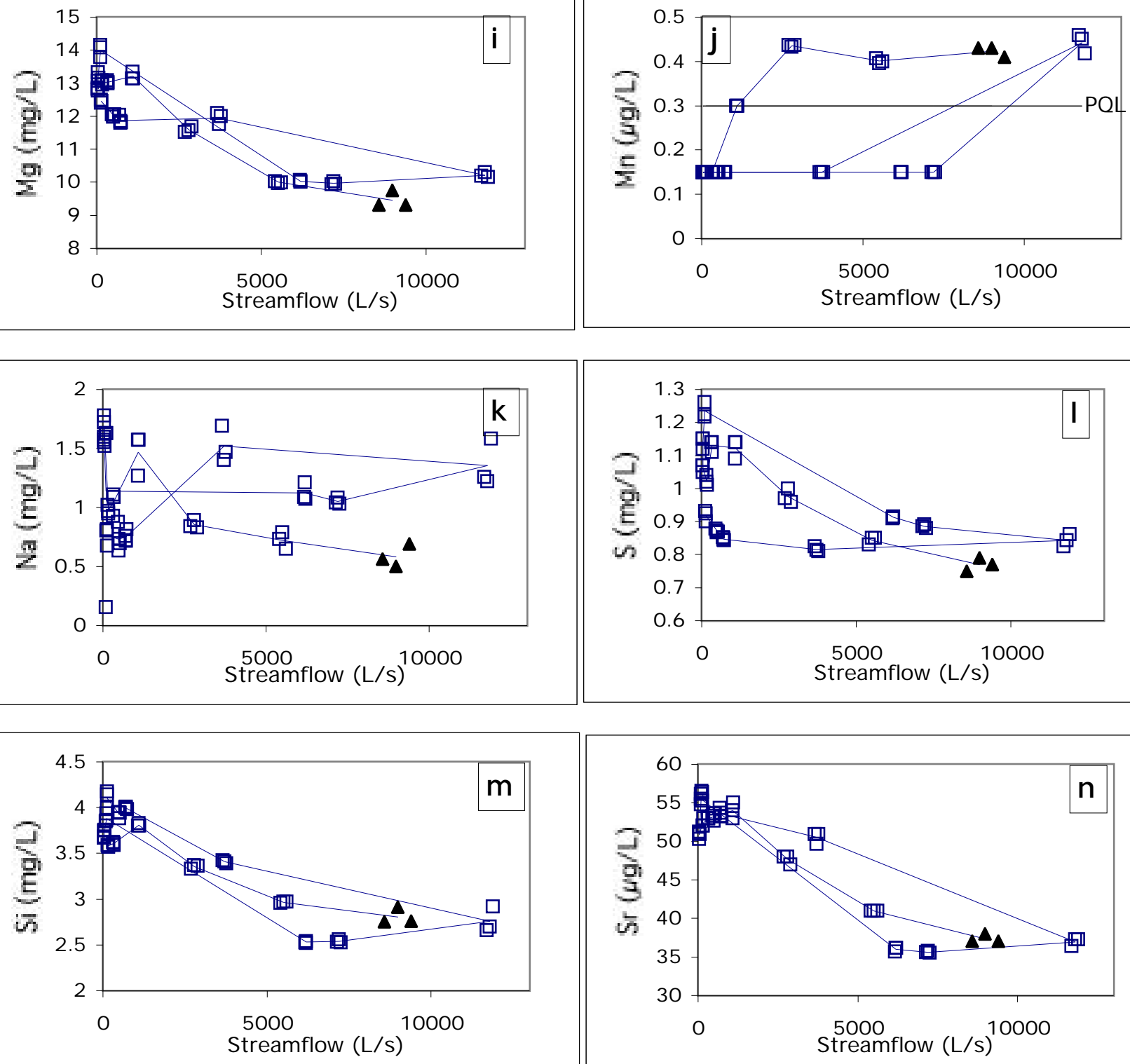
Figures 9a-9h: Trends over time at Landers Fork site "LB"
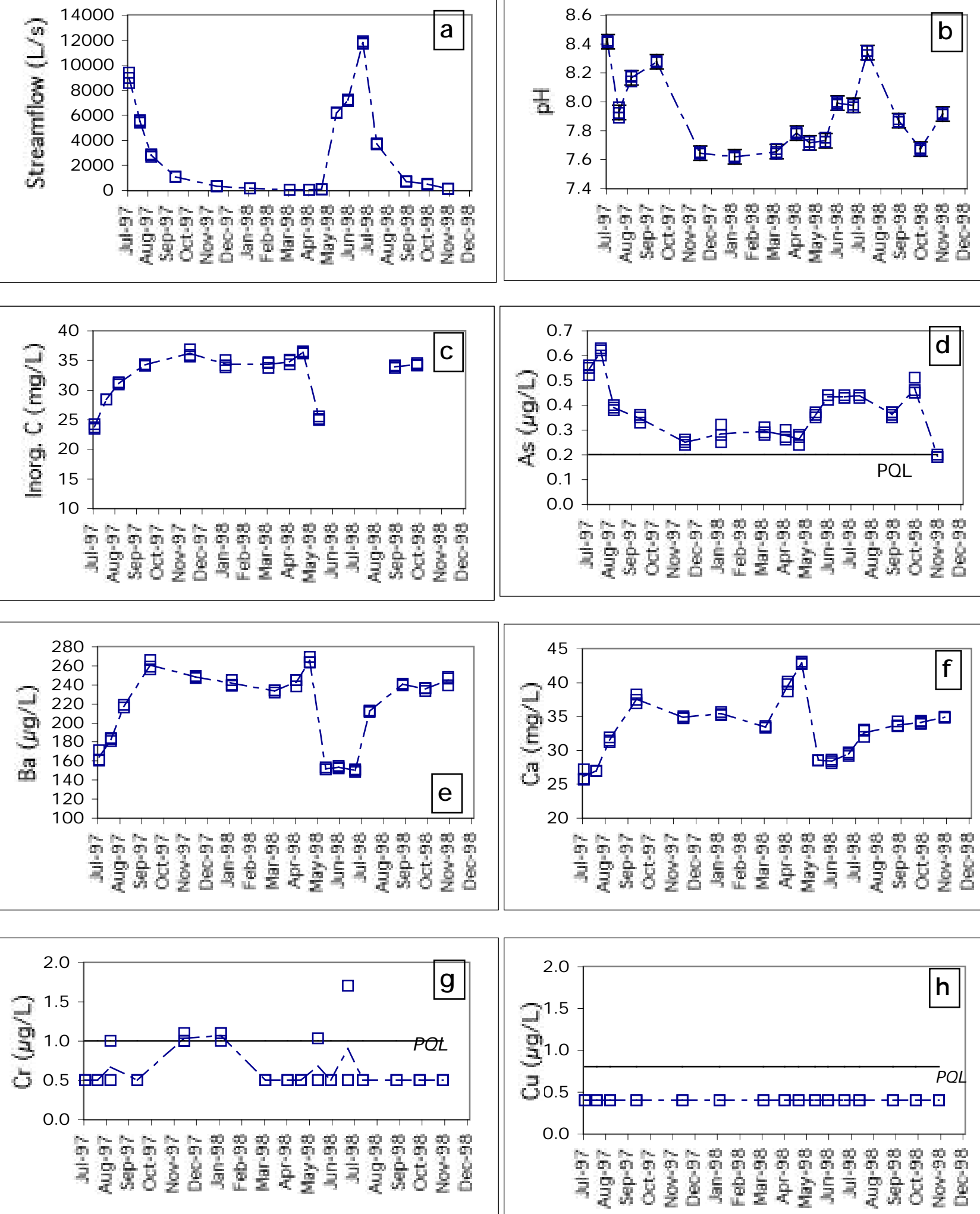
Figures 9i-9p: Trends over time at Landers Fork site "LB"
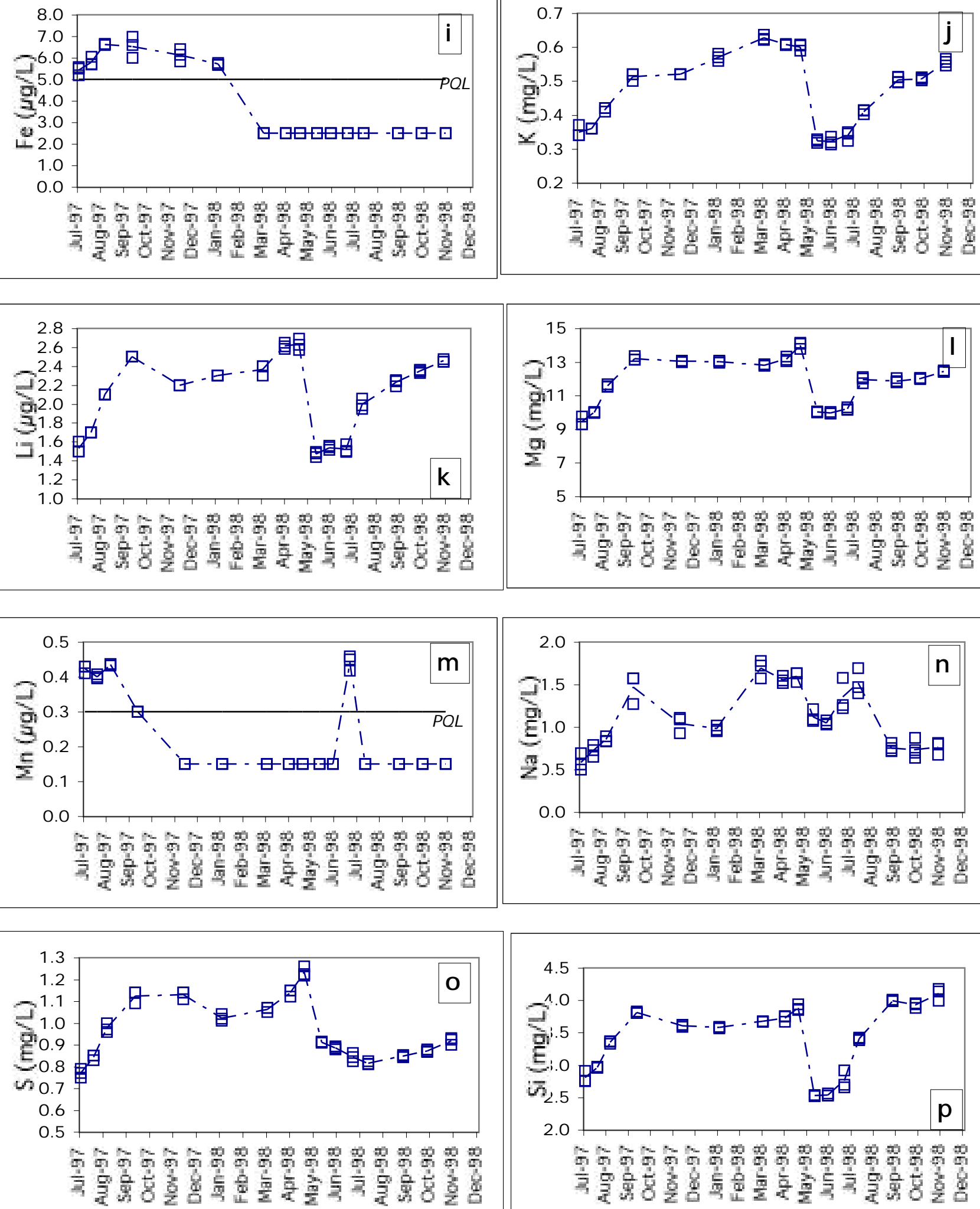
Figures 9q-9r: Trends over time at Landers Fork site "LB"
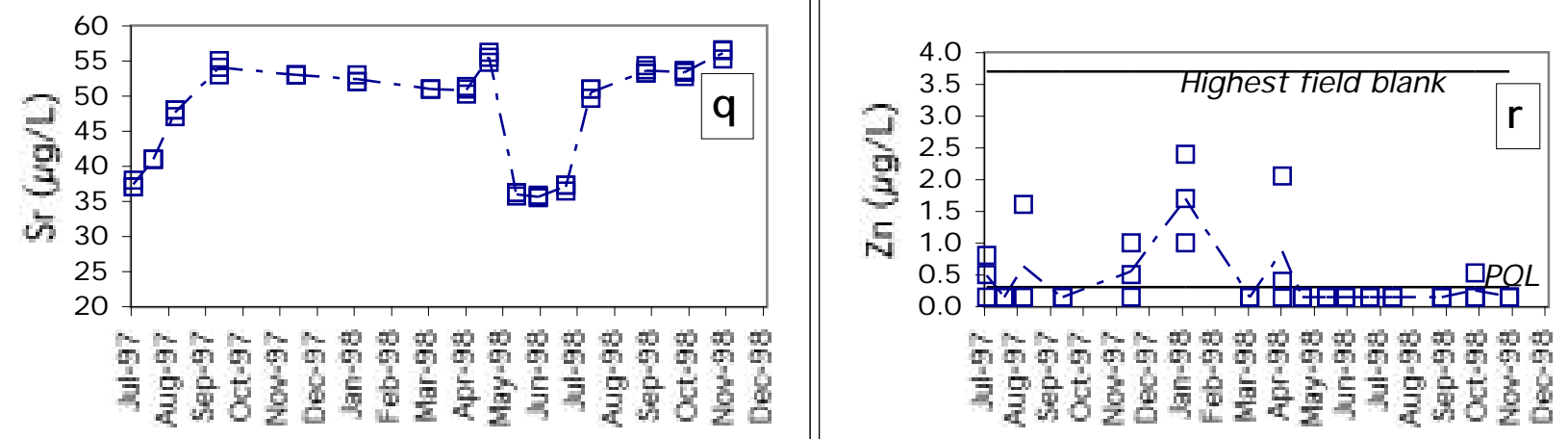
Figure 10a: Inorganic carbon, $\mathrm{Ca}$, and $\mathrm{Mg}$ loads at site LB

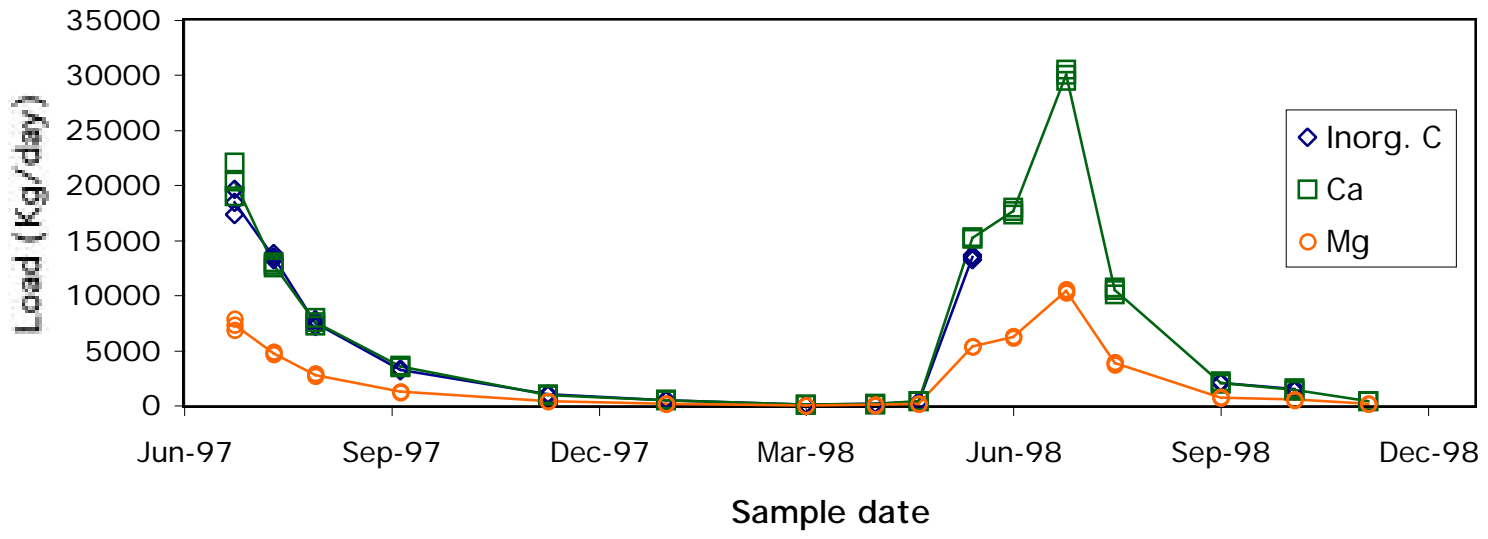

Figure 10b: As and Mn loads at site LB

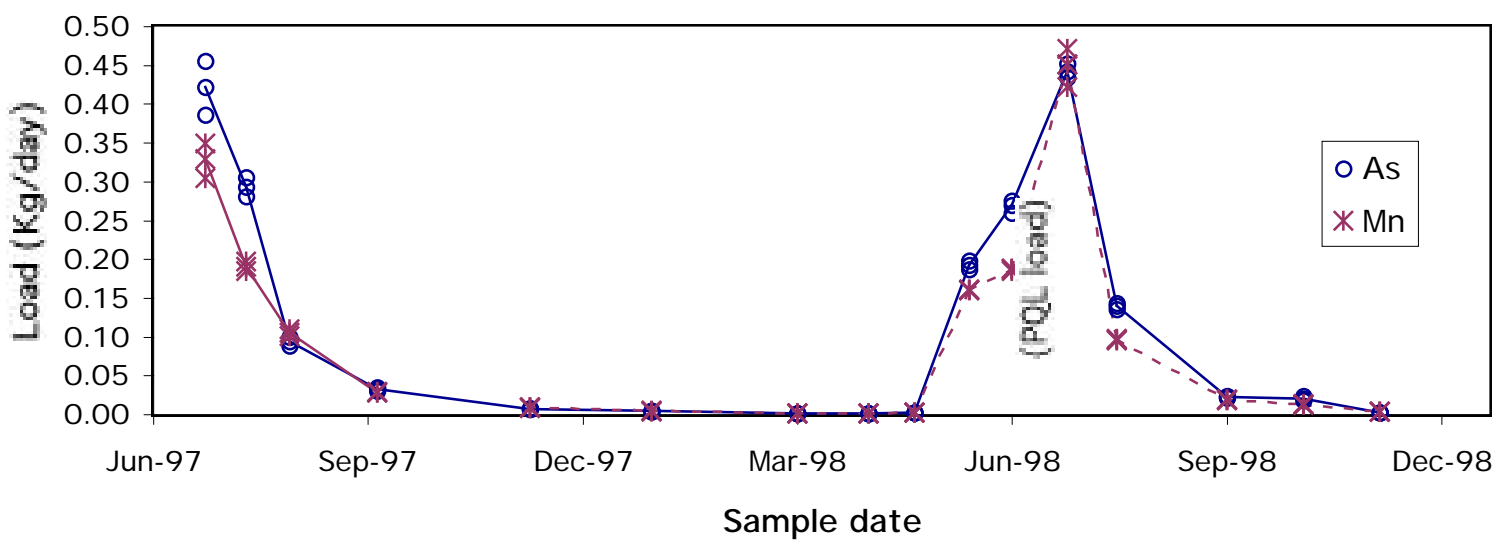

Figure 10c: S, Si, and $\mathrm{Na}$ loads at site LB

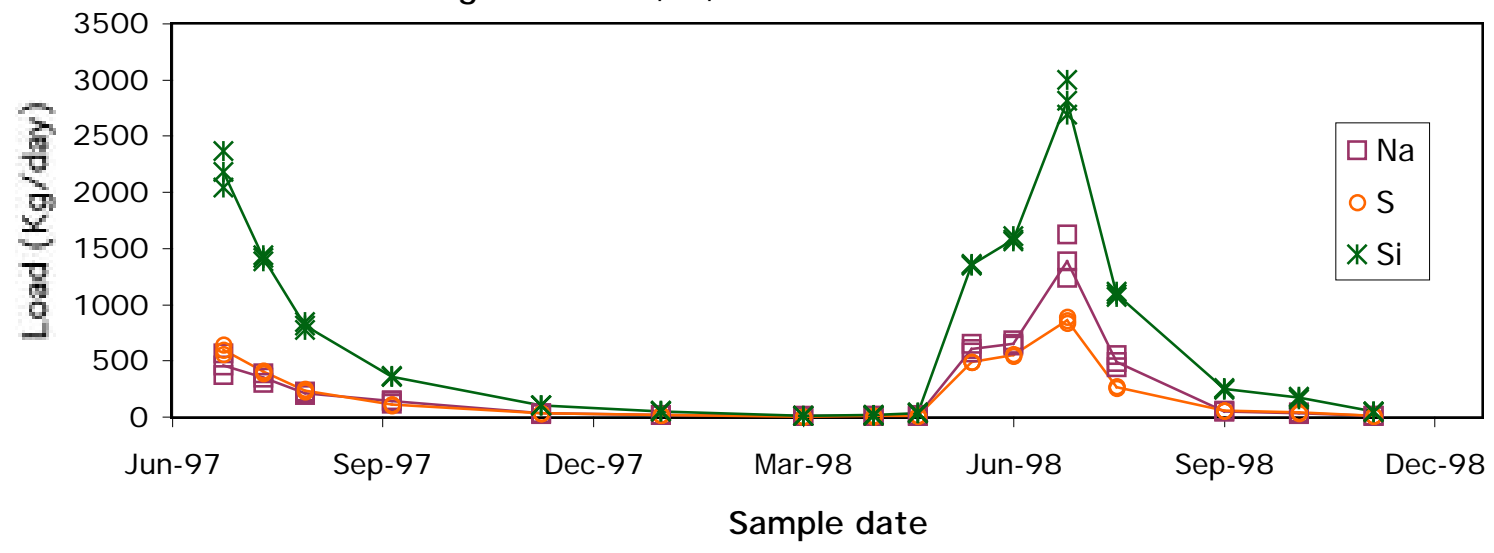


Figure 10d: Fe and Li loads at site LB

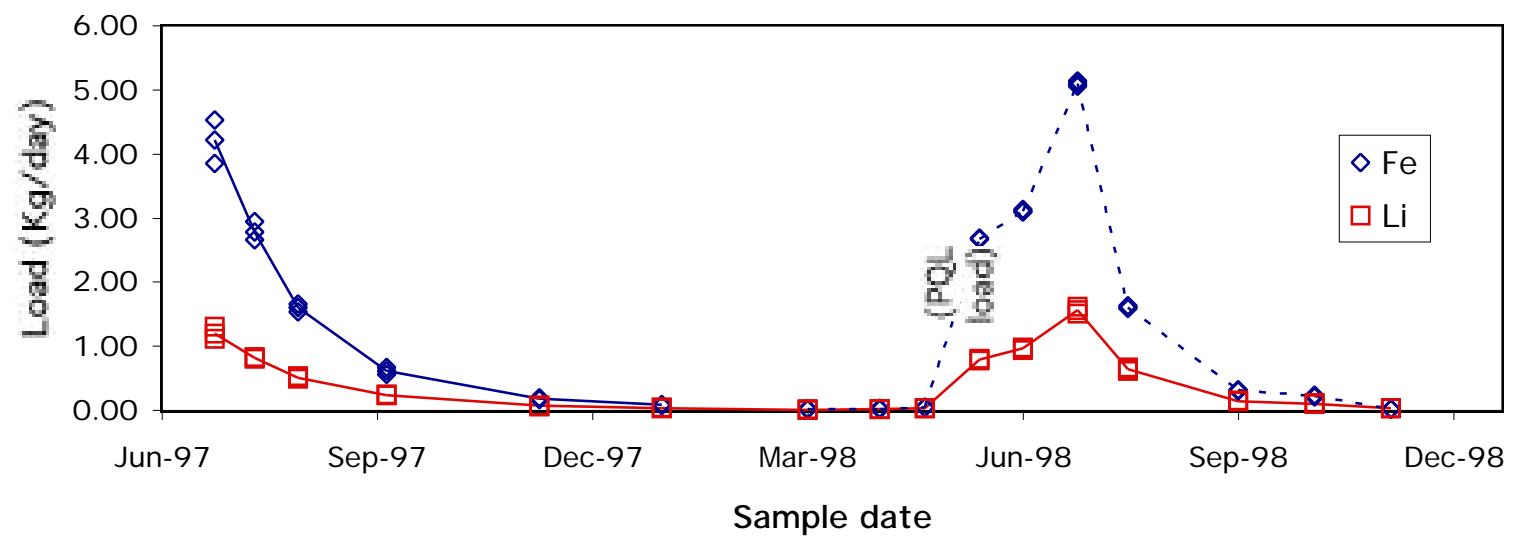

Figure 10e: Ba, K, and Sr loads at site LB

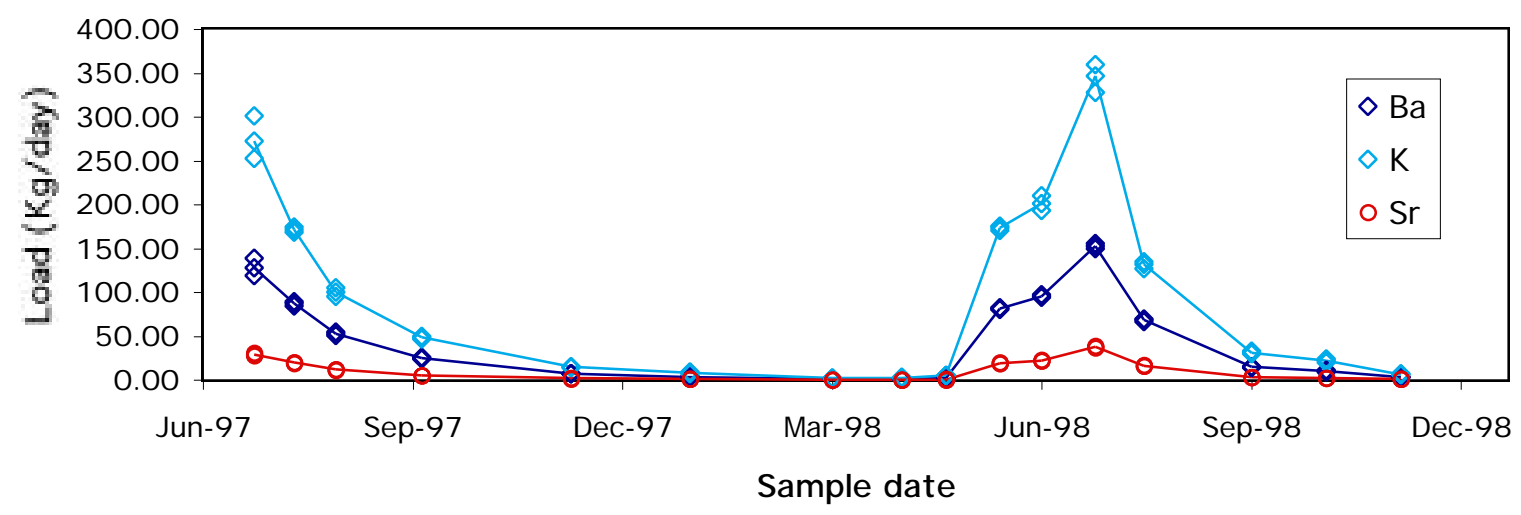


Figure 11a-11h: Streamflow vs. concentrations at Landers Fork site "LC"
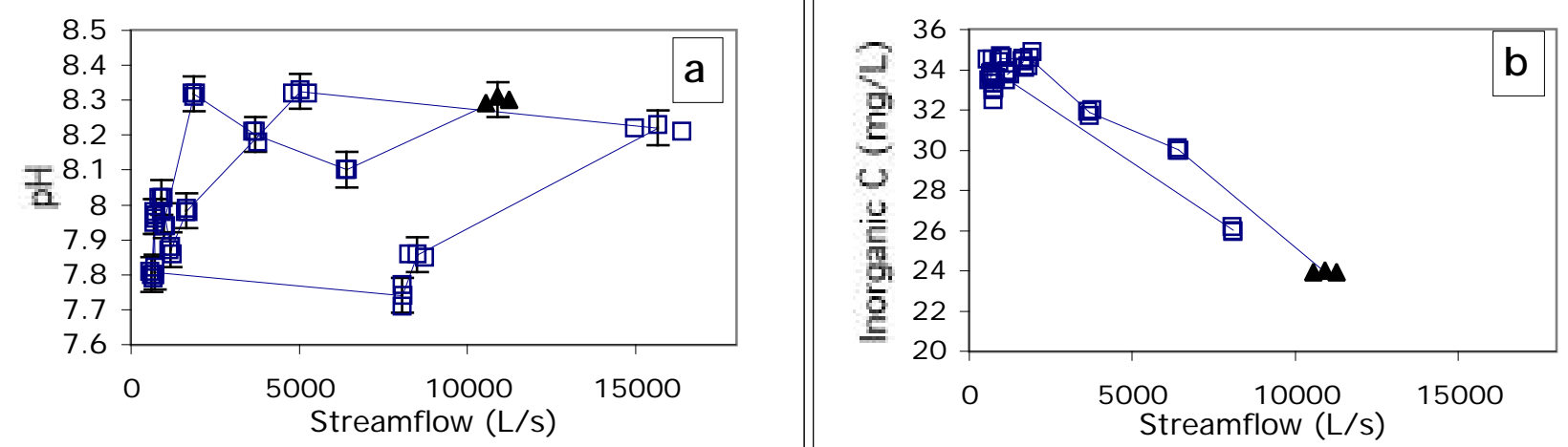

(Triangles indicate first sampling date, 7/3/97)
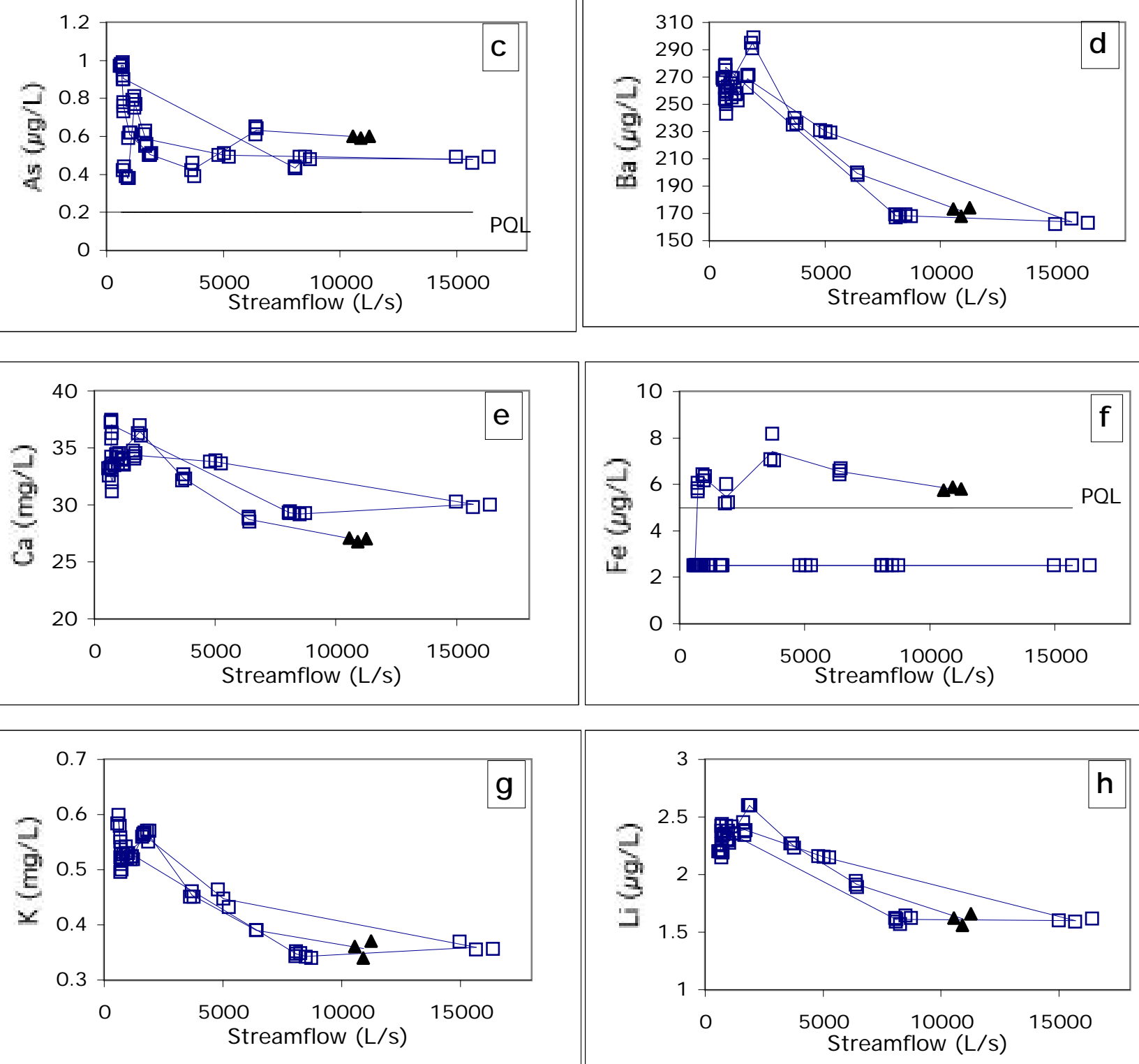
Figure $11 \mathrm{i}-11 \mathrm{n}$ : Streamflow vs. concentrations at Landers Fork site "LC"
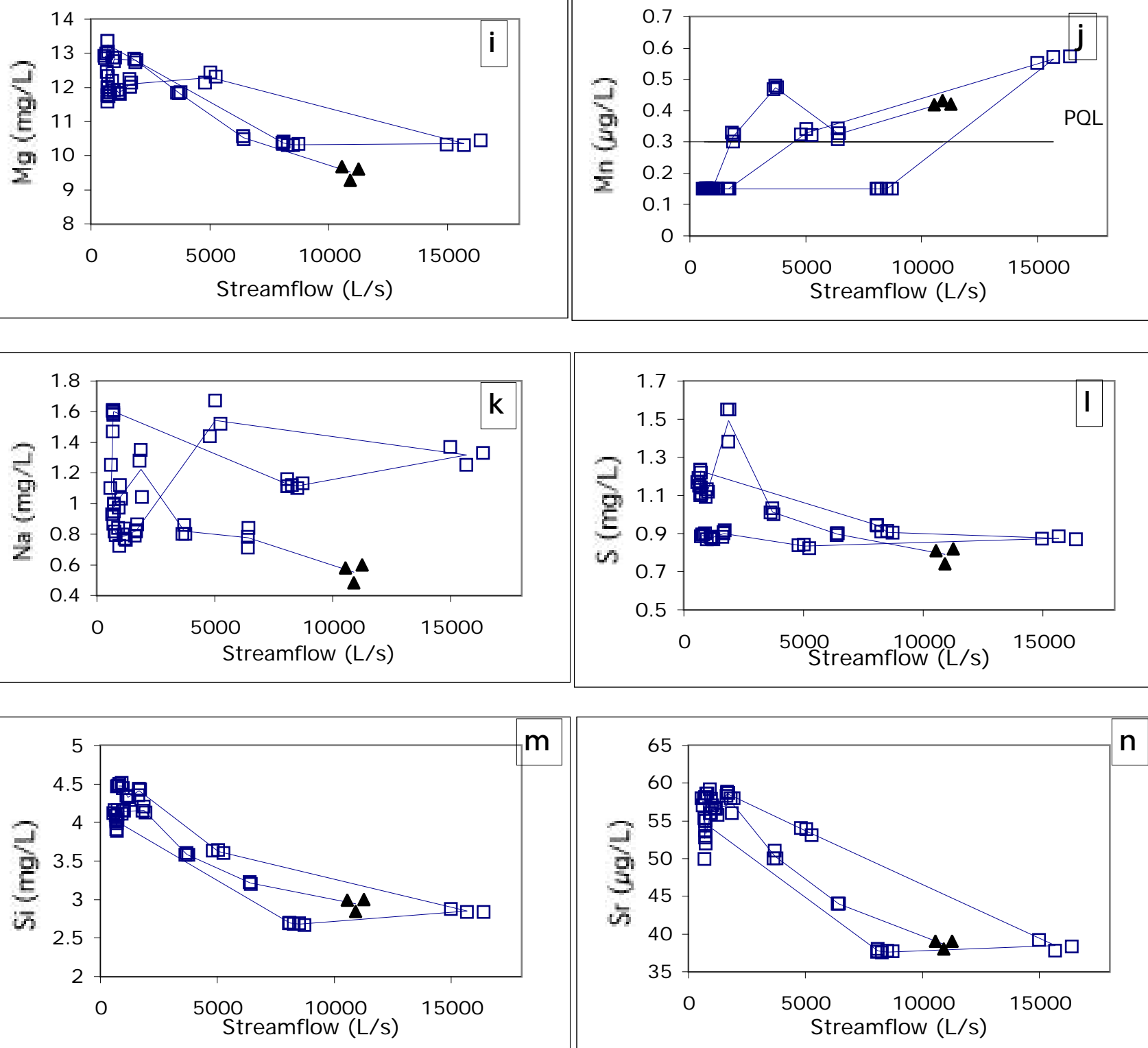
Figure 12a-12h: Trends over time at Landers Fork site "LC"
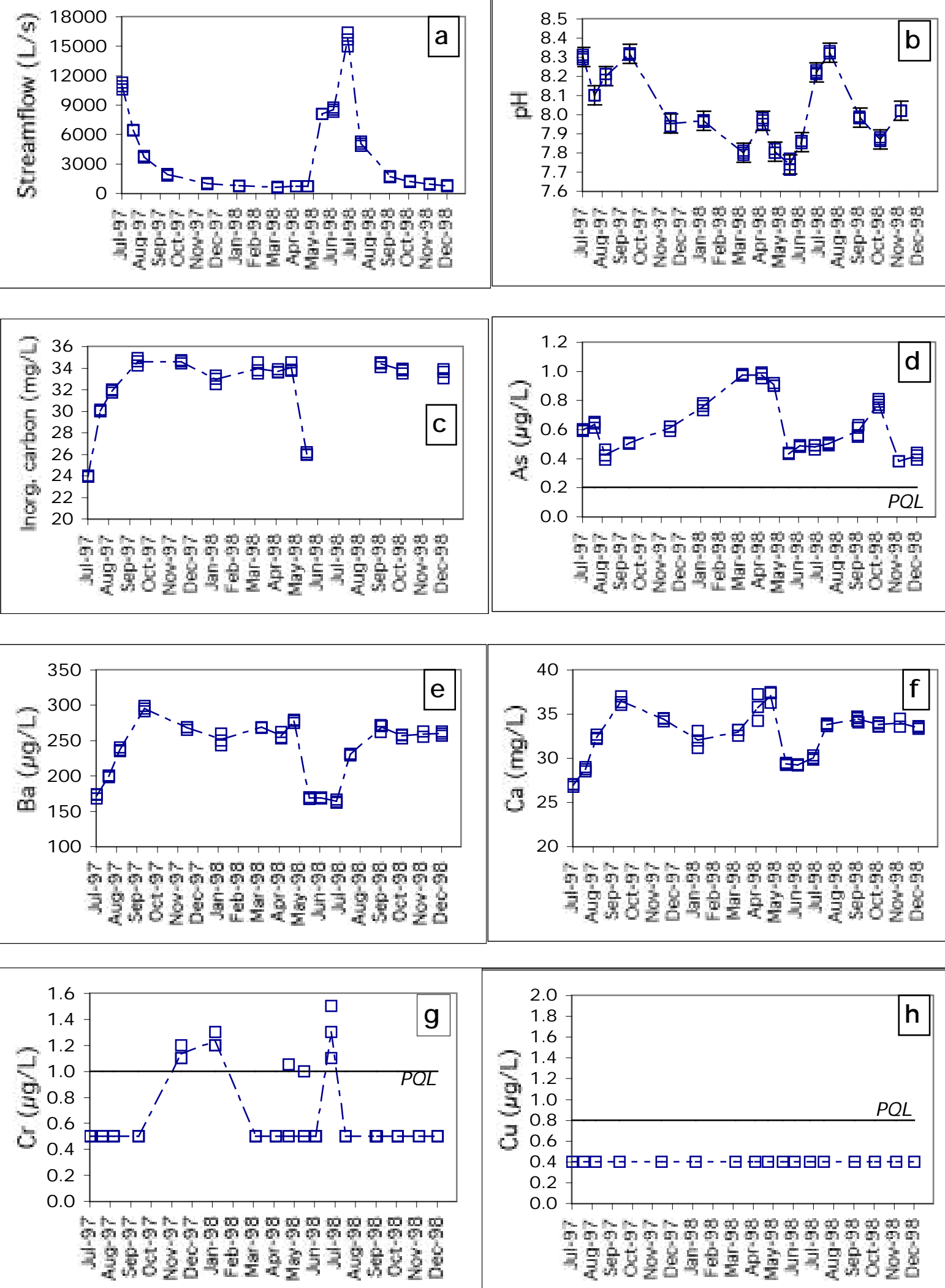
Figure $12 \mathrm{i}-12 \mathrm{p}$ : Trends over time at Landers Fork site "LC"
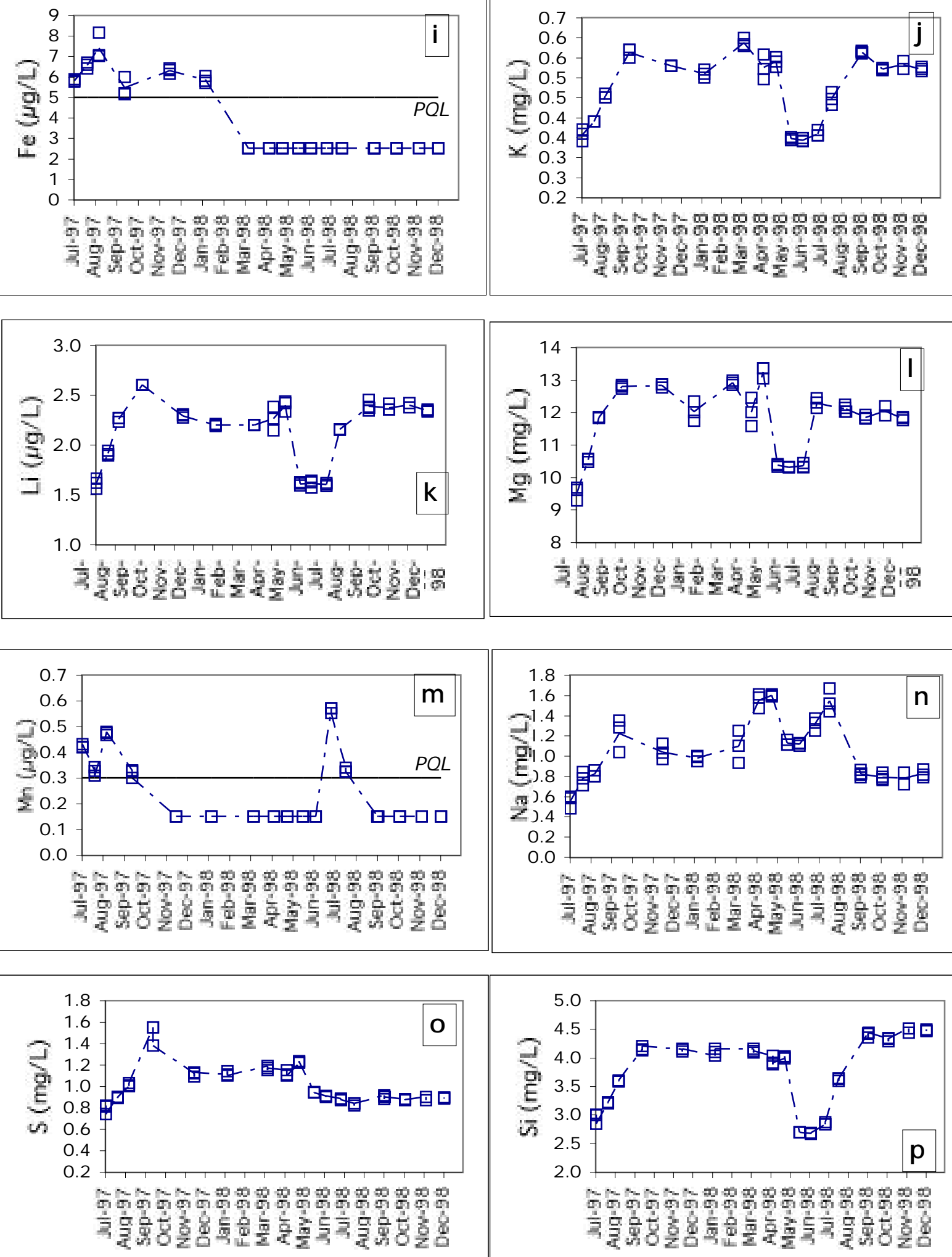
Figure 12q-12r: Trends over time at Landers Fork site "LC"
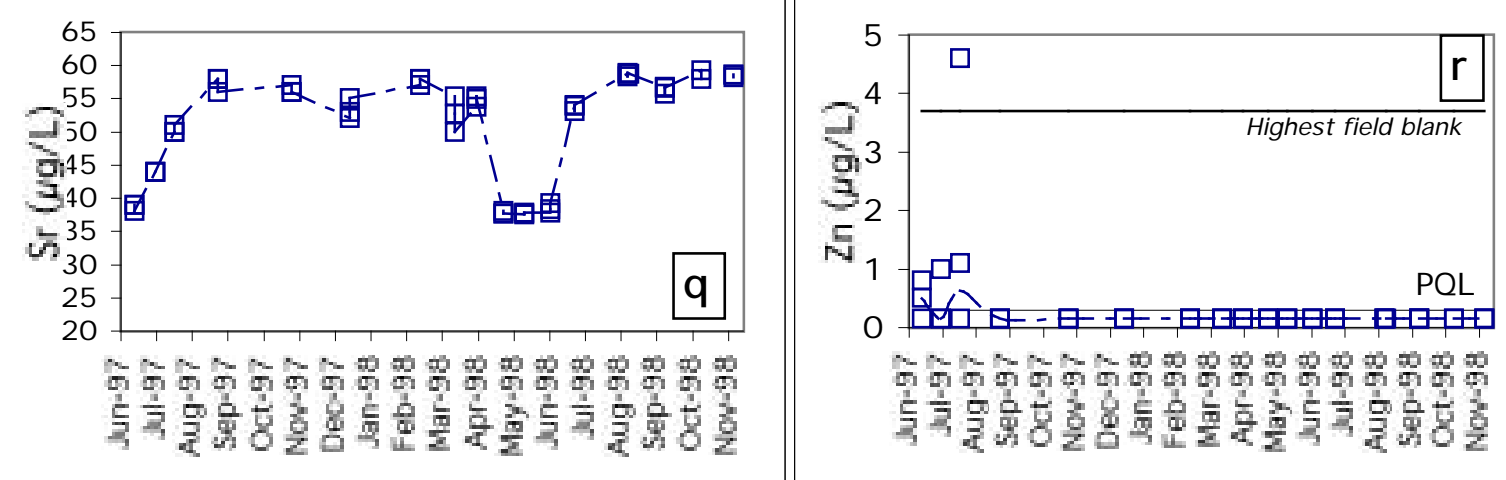

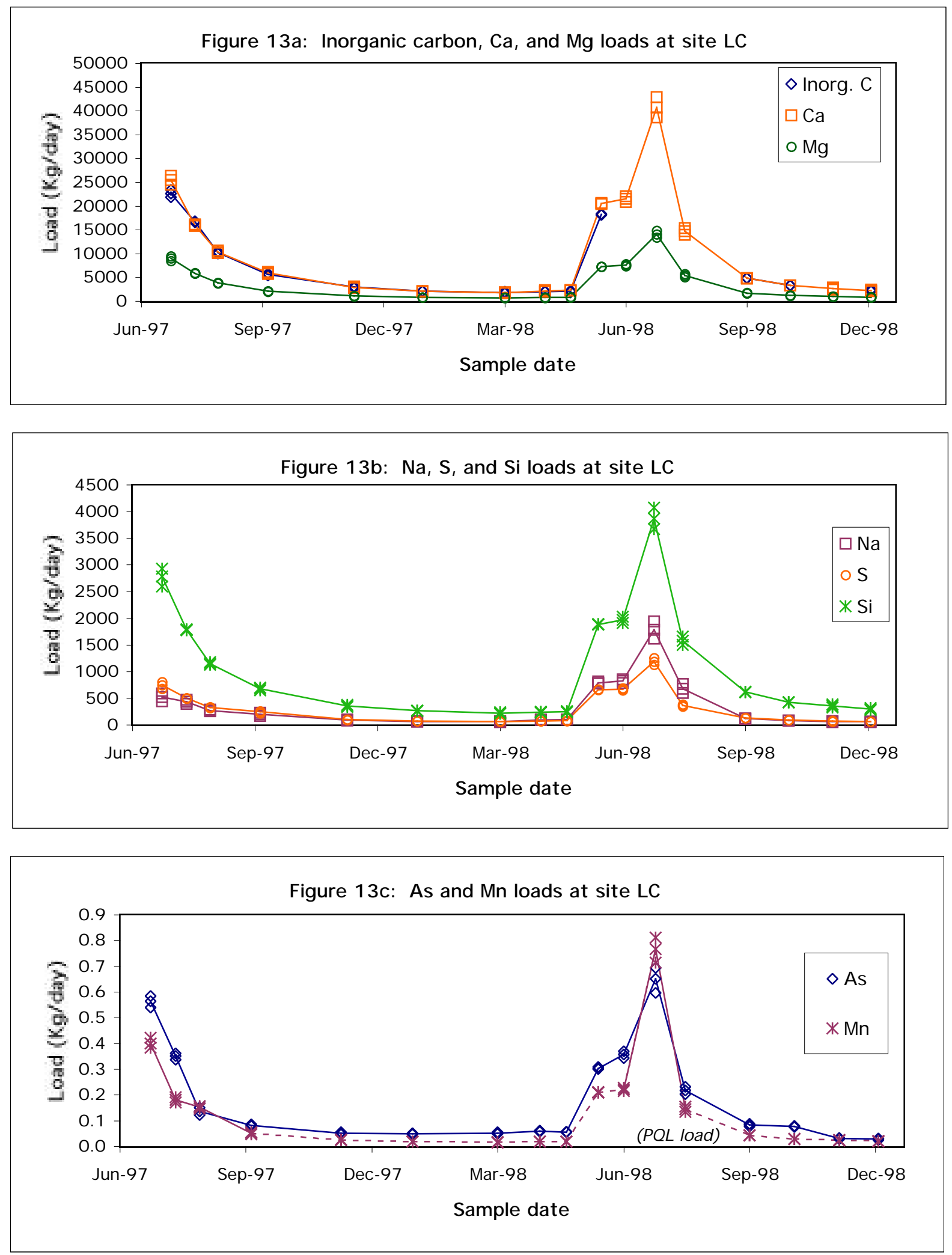


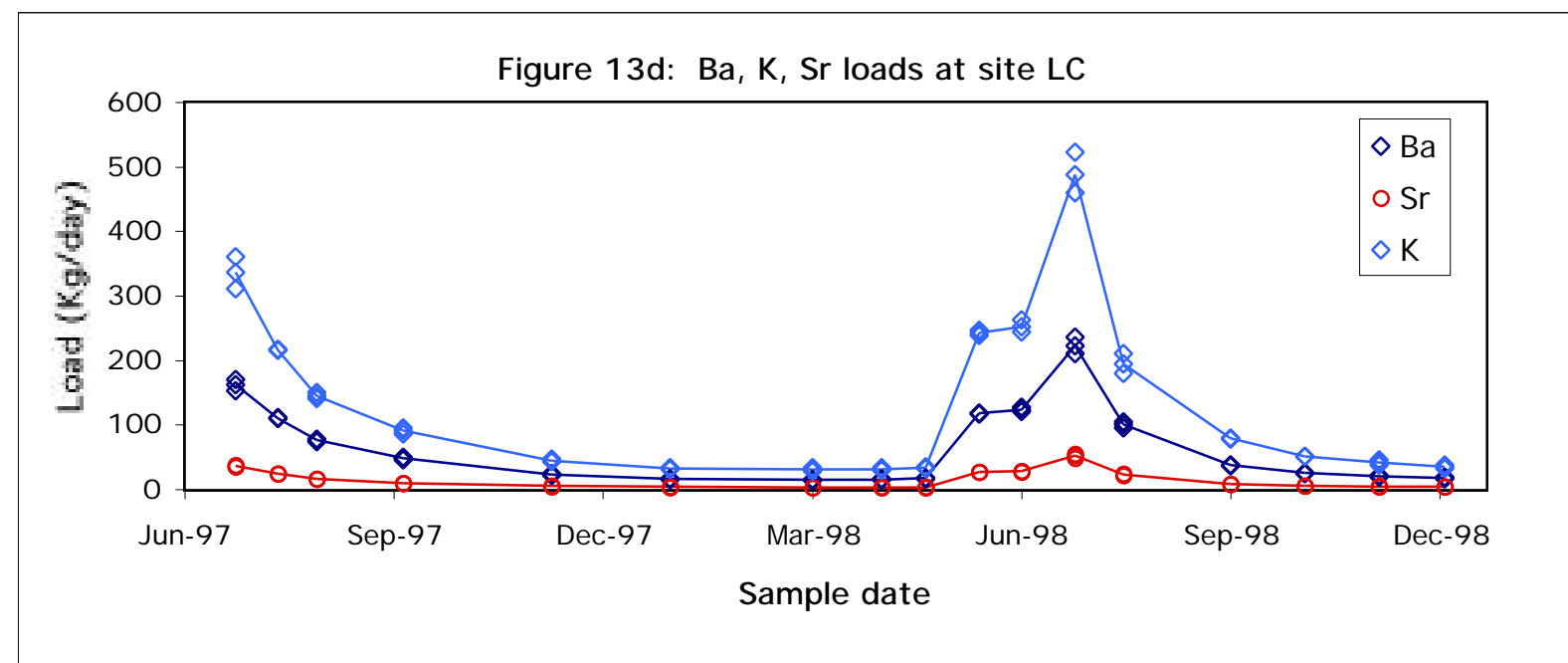

Figure 13e: Fe and Li loads at site LC

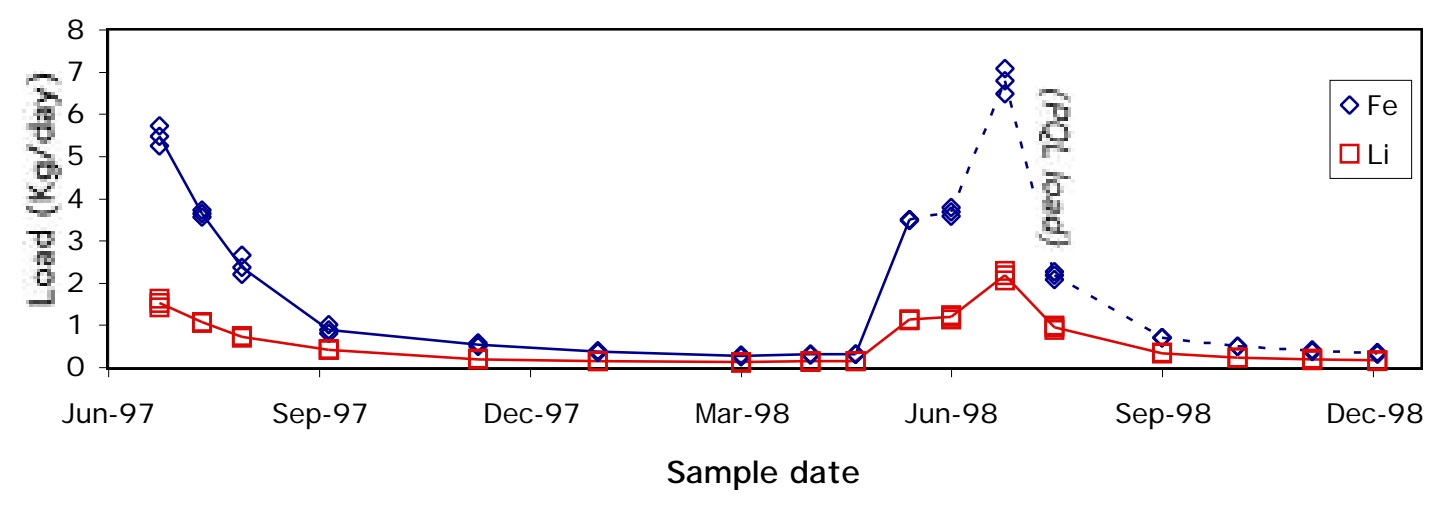


Figures 14a-14h: Streamflow vs. concentrations at Landers Fork "LD"
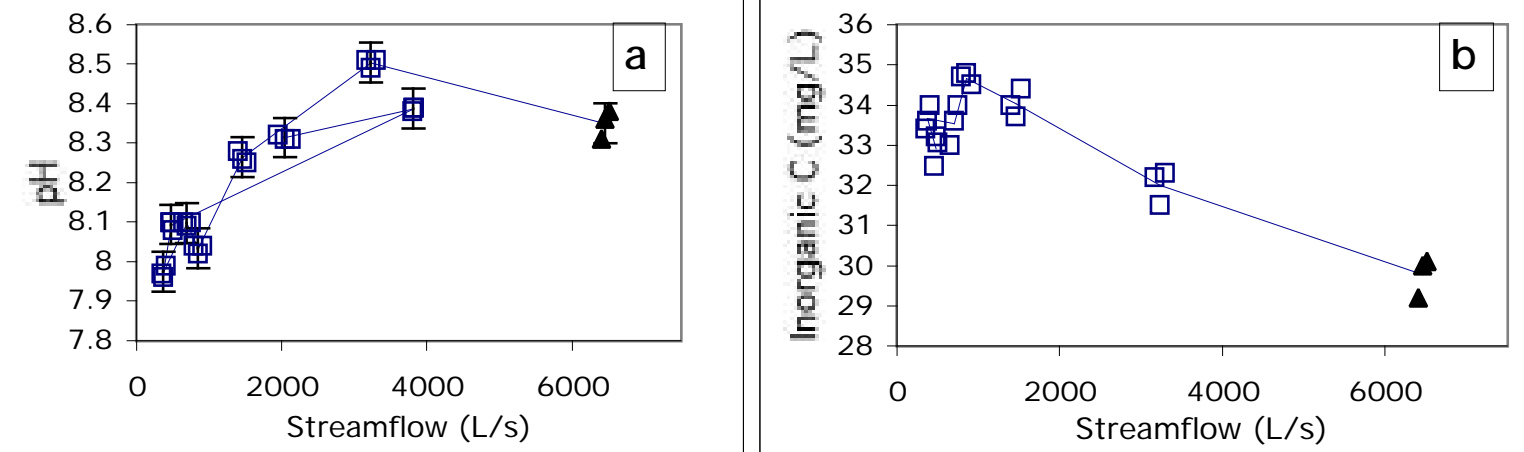

(Triangles indicate first sampling event, 7/20/97)
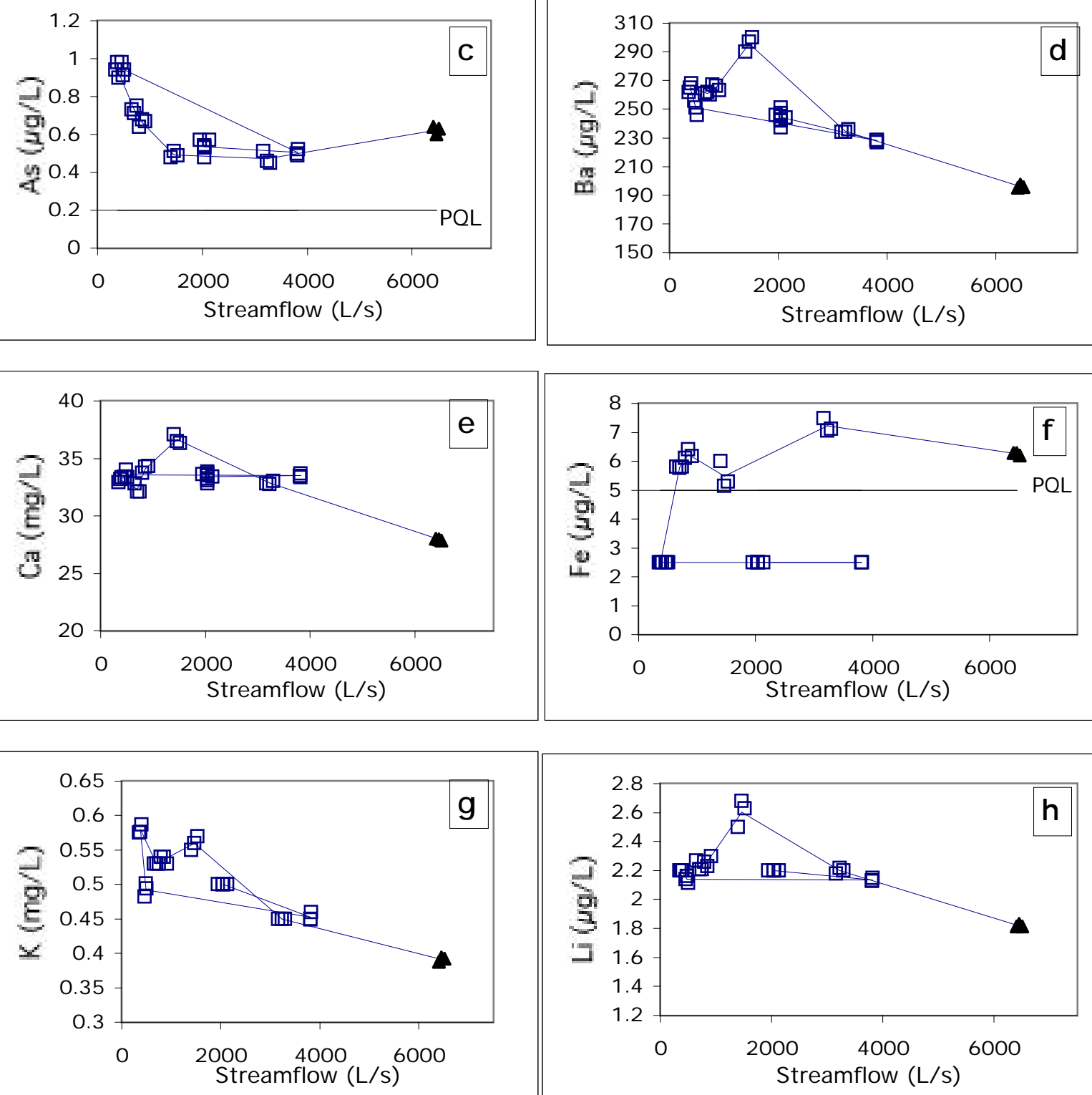
Figures 14i-14n: Streamflow vs. concentrations at Landers Fork "LD"
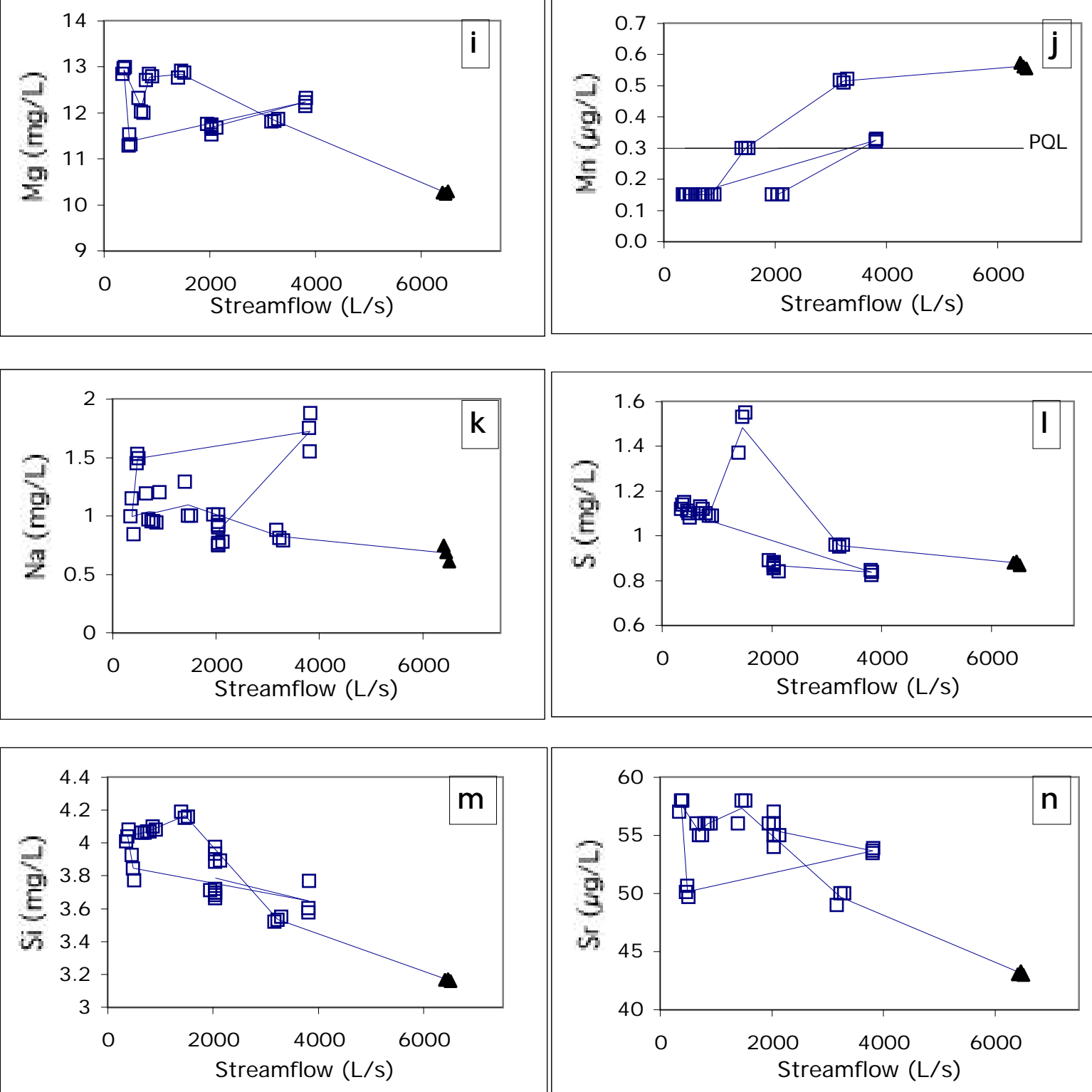
Figures 15a-15h: Trends over time at Landers Fork site "LD"
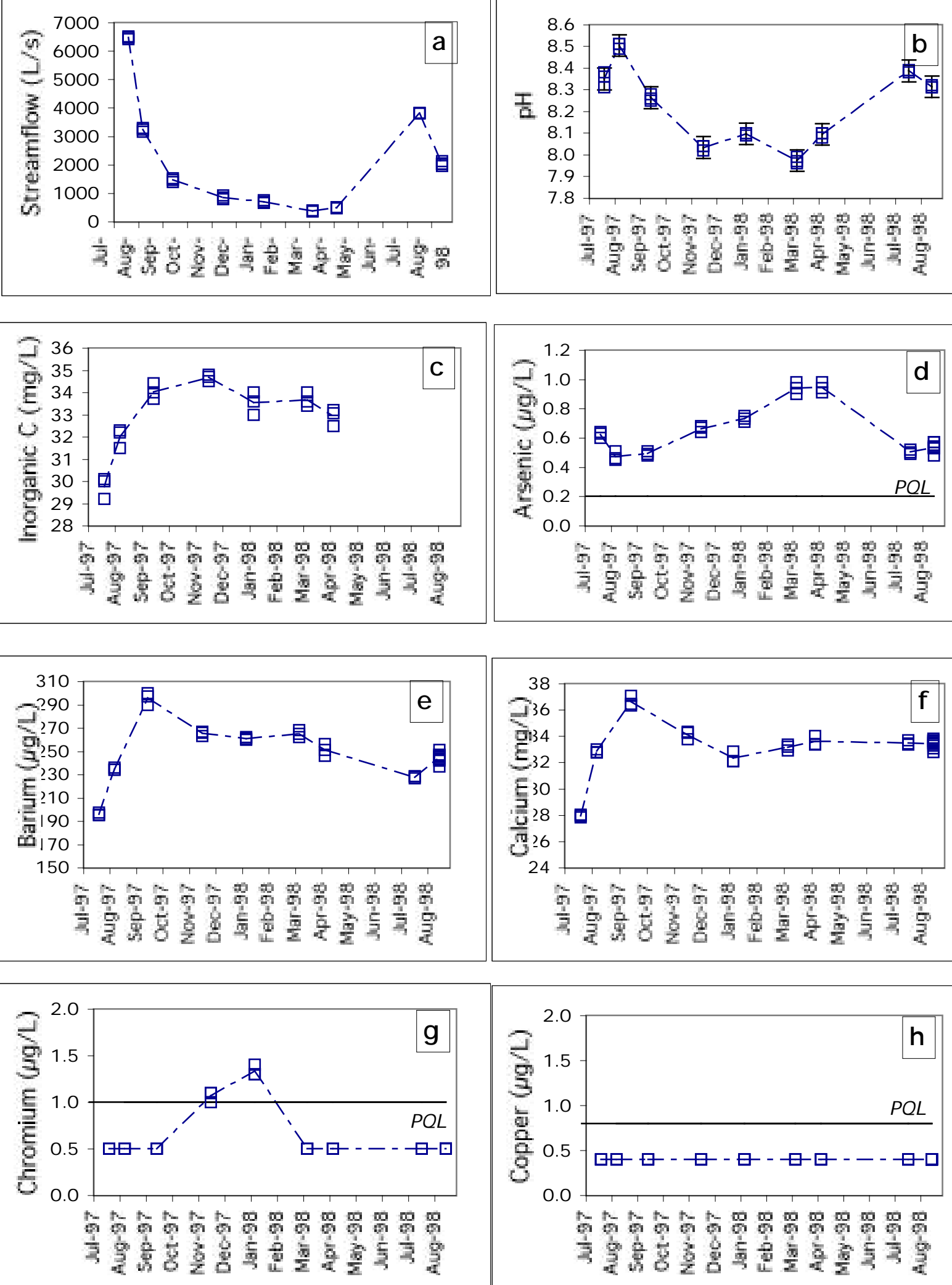
Figures 15i-15p: Trends over time at Landers Fork site "LD"
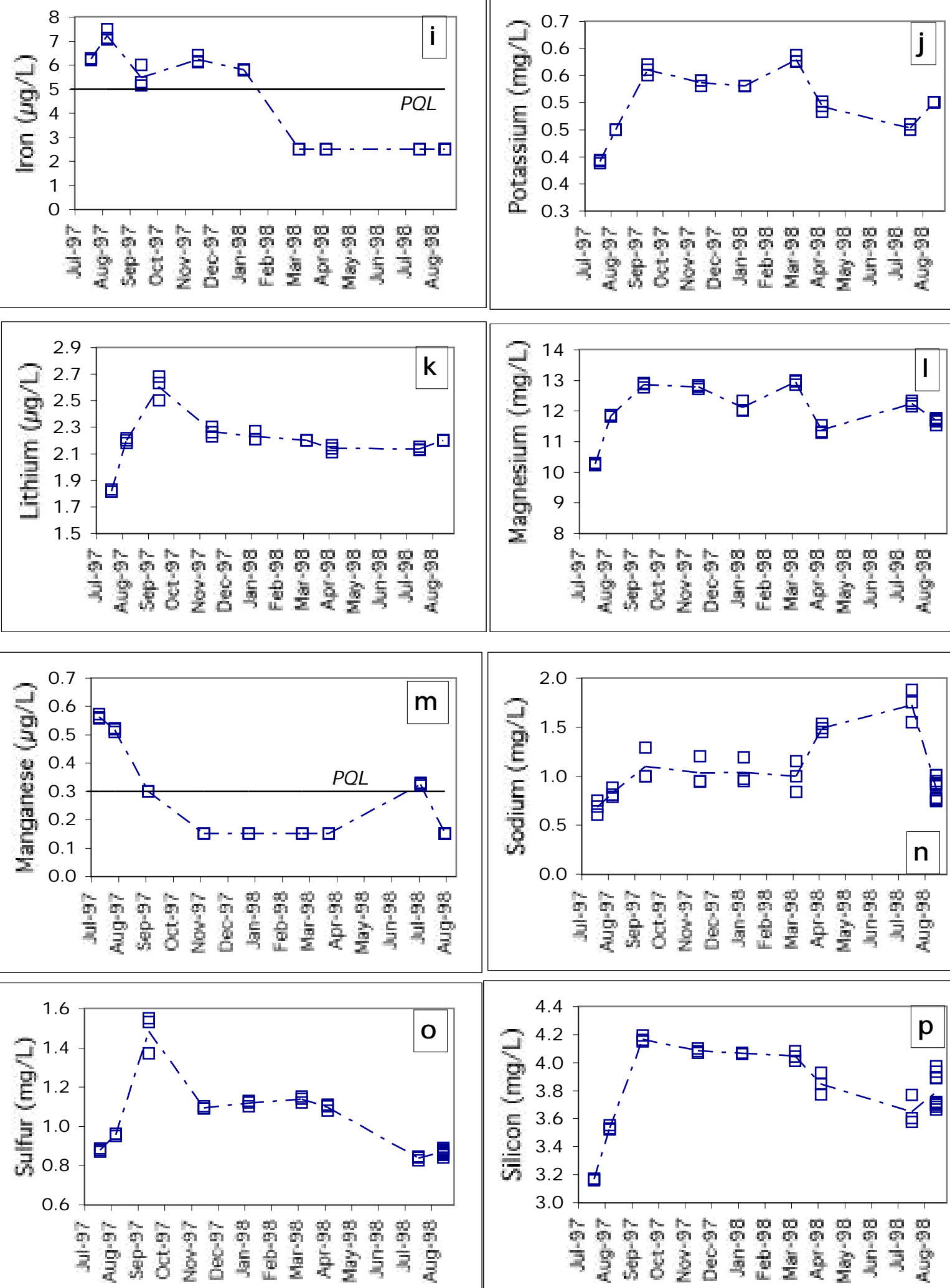
Figures 15q-15r: Trends over time at Landers Fork site "LD"

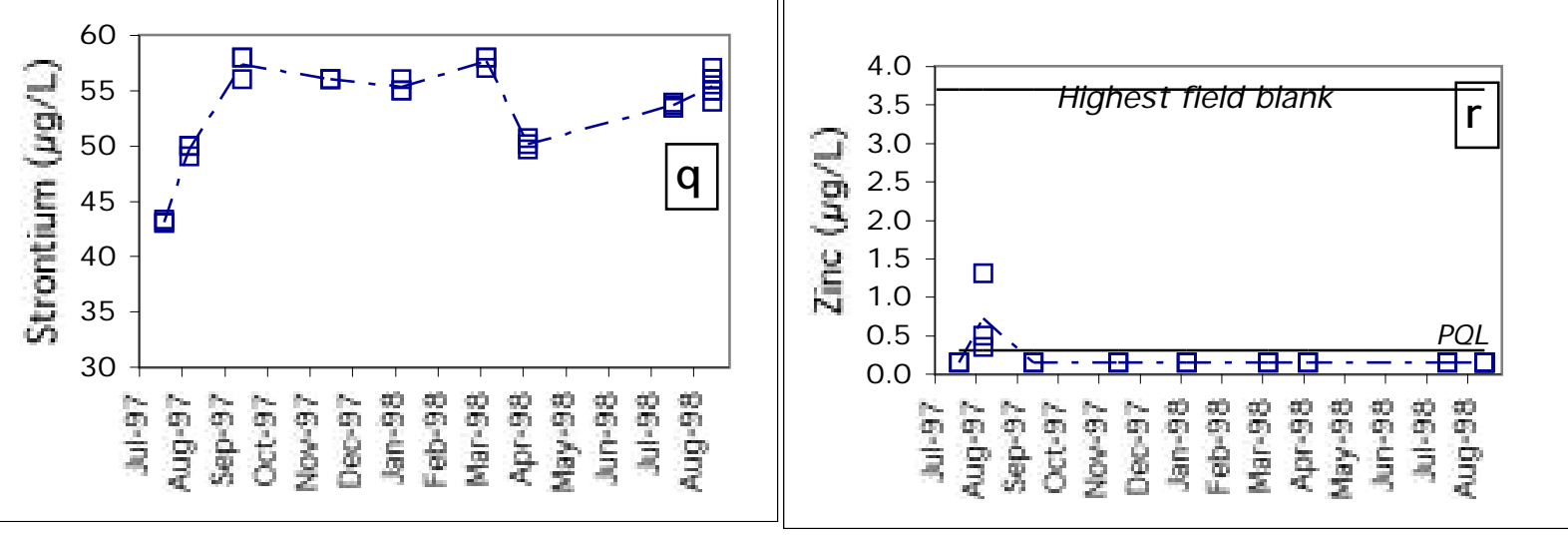


Figure 16a: Inorganic carbon, $\mathrm{Ca}$, and Mg loads at site LD

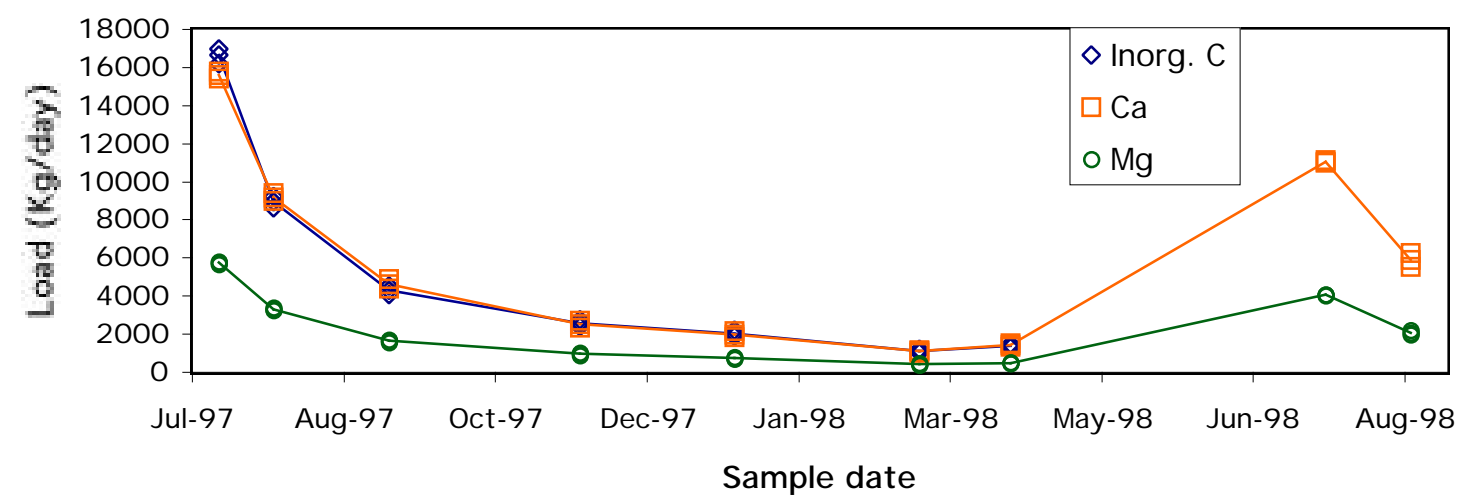

Figure $16 \mathrm{~b}: \mathrm{Na}, \mathrm{S}$, and Si loads at site LD

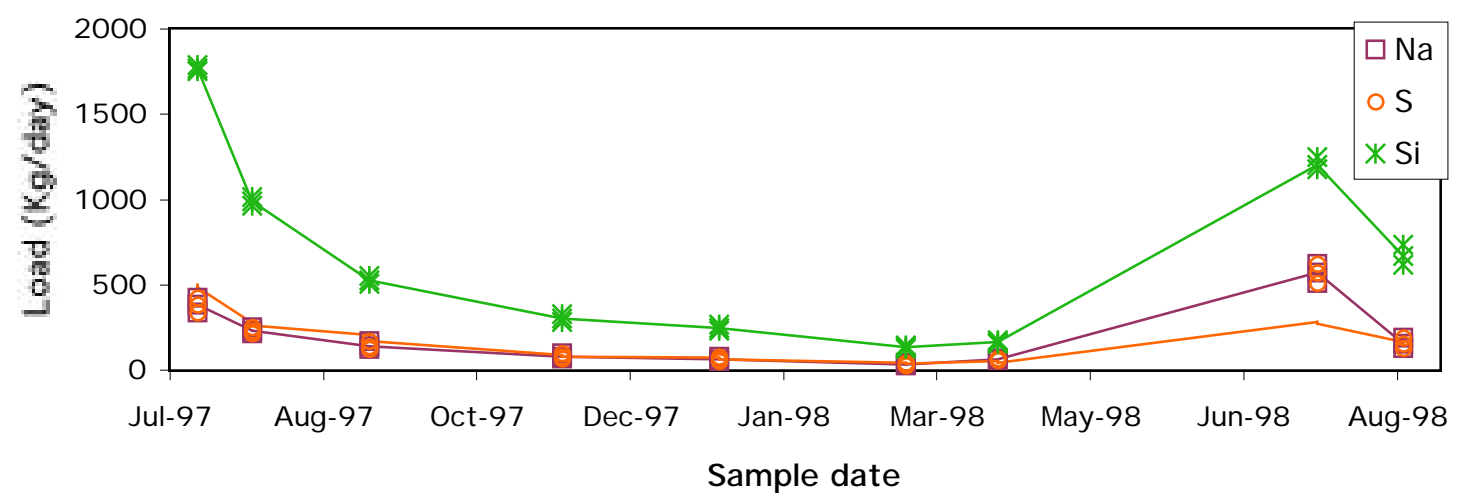

Figure 16c: As and Mn loads at site LD

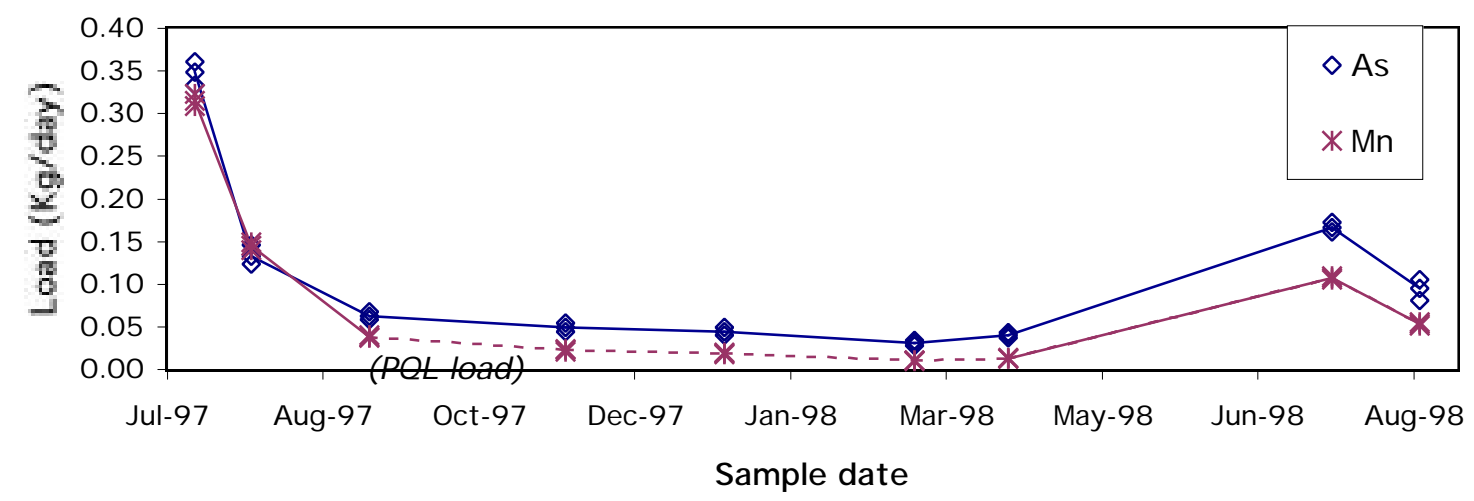


Figure 16d: Ba, K, Sr loads at site LD

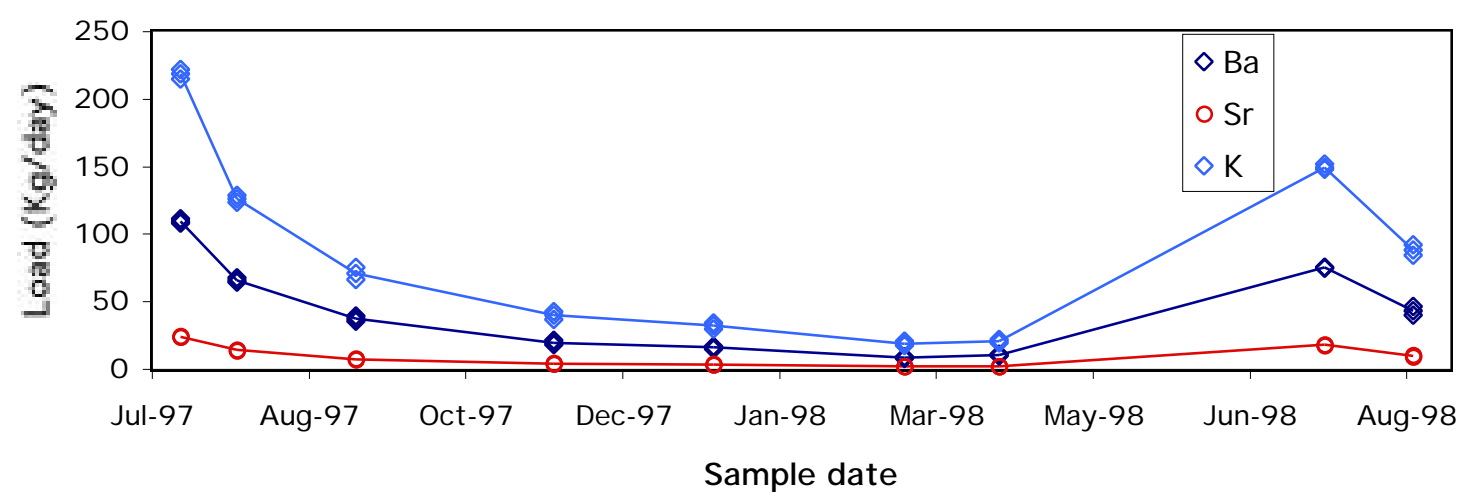

Figure 16e: Fe and Li loads at site LD

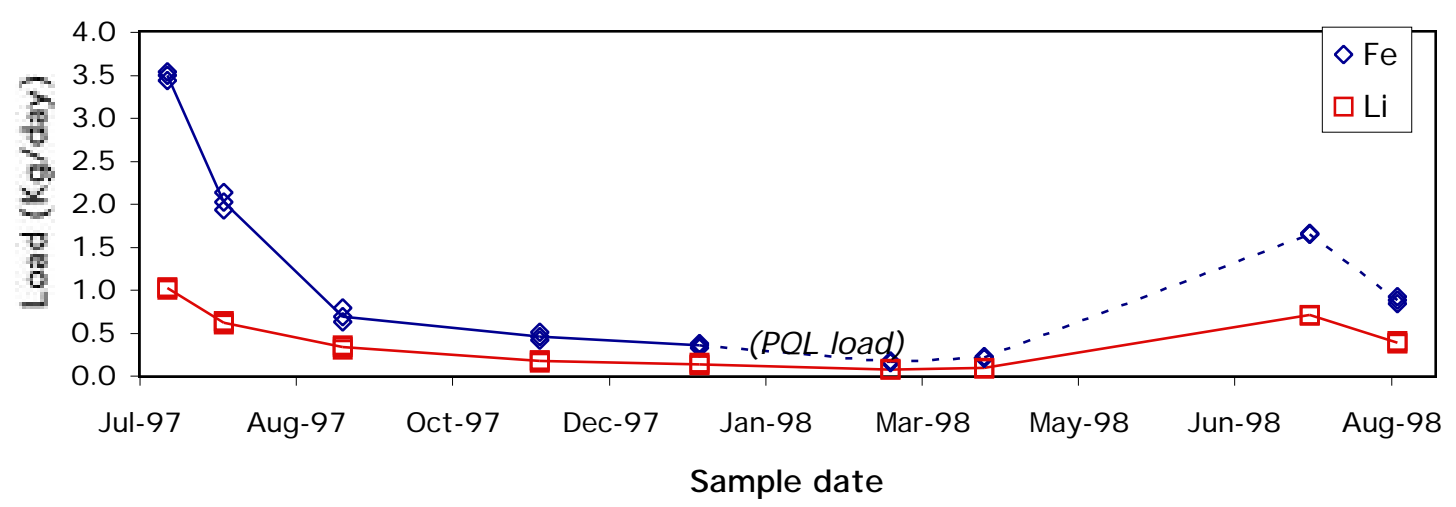


Figures 17a-17h: Streamflow v. concentrations at Blackfoot River site "BH"
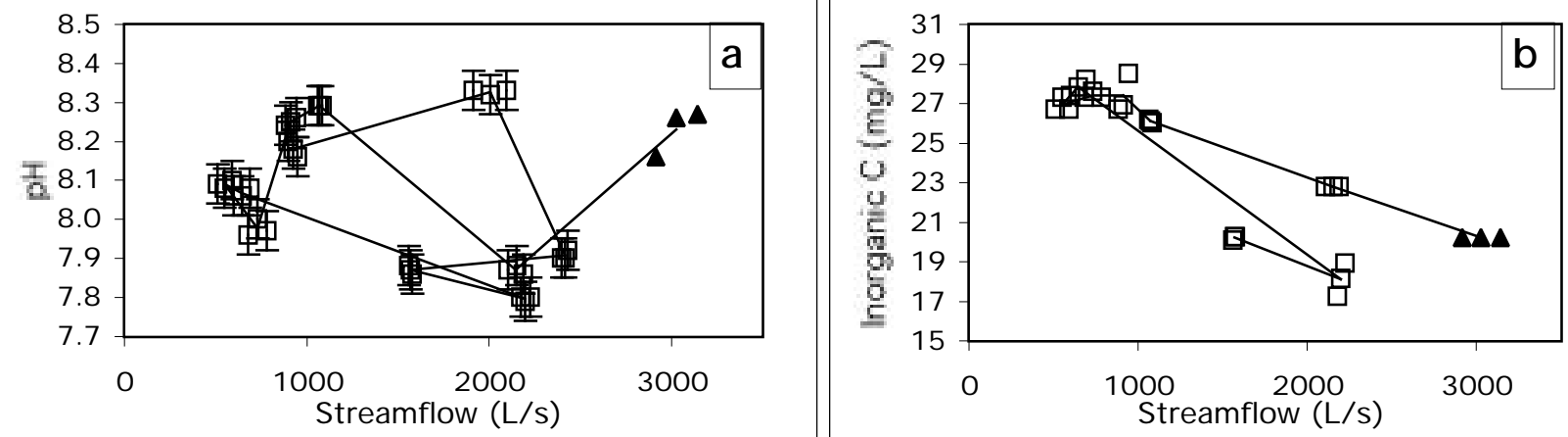

Triangles indicate the first sampling event, on $7 / 4 / 97$
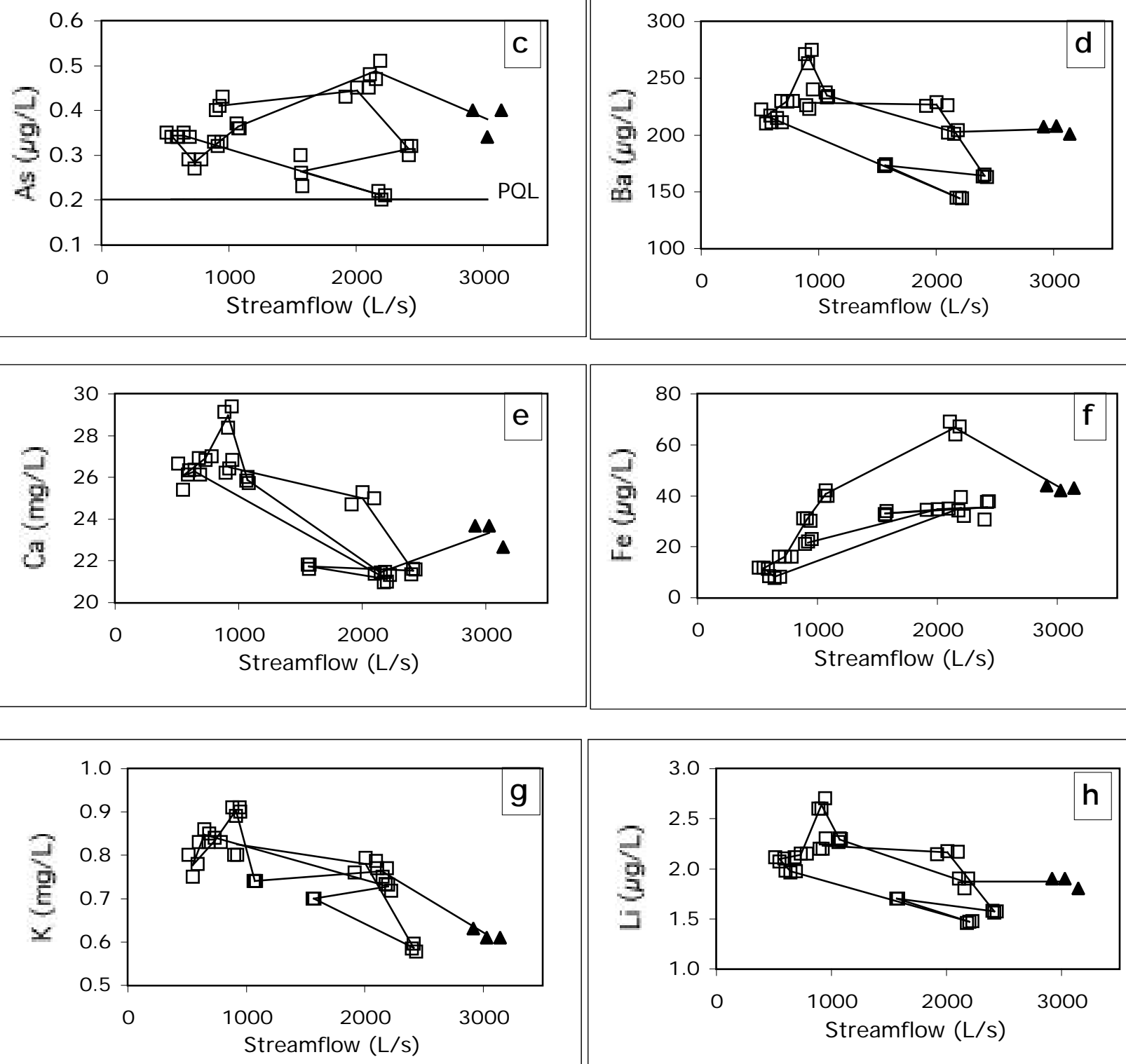
Figures 17i-170: Streamflow v. concentrations at Blackfoot River site "BH"
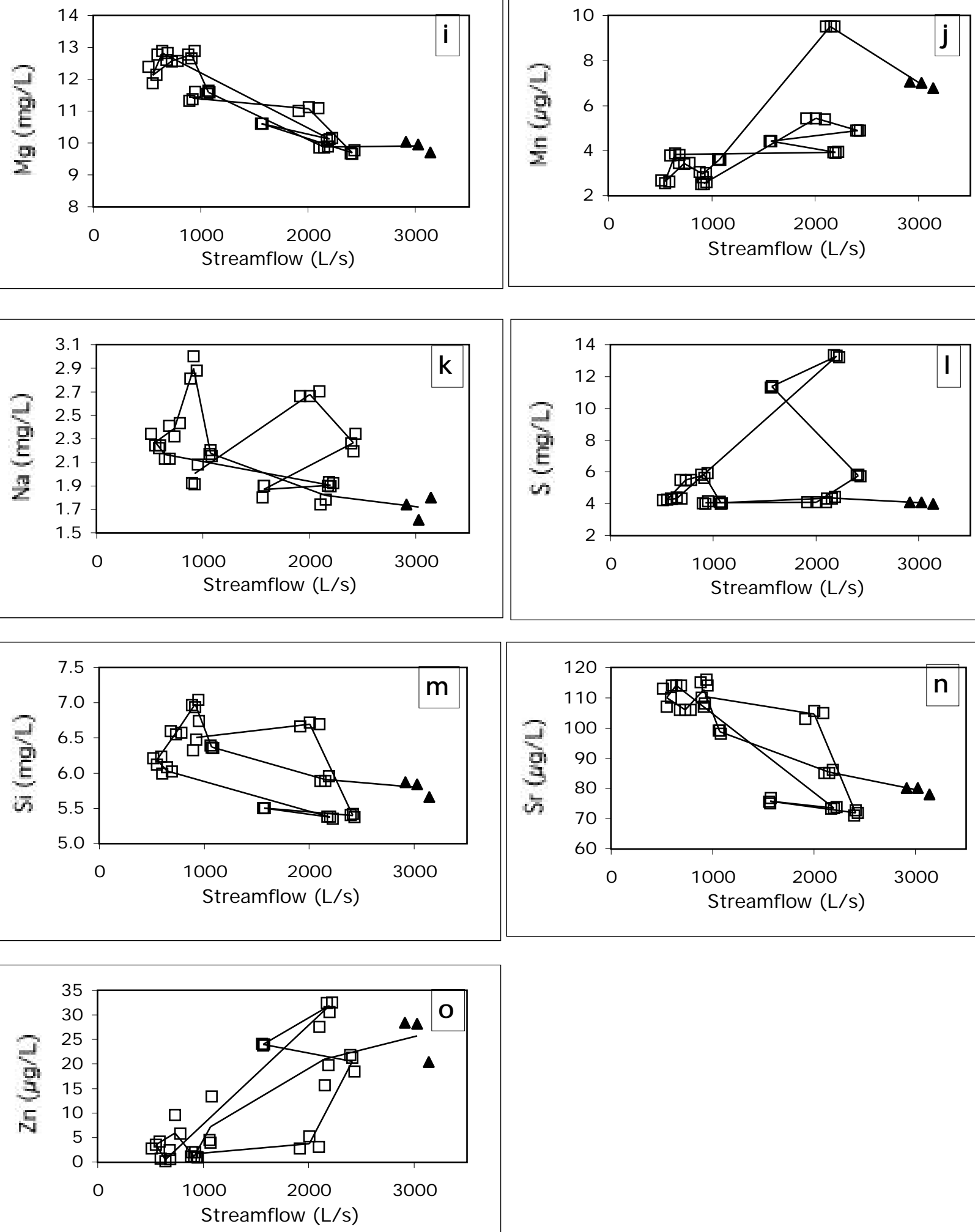
Figure 18a-18h: Trends over time at Blackfoot River site "BH"
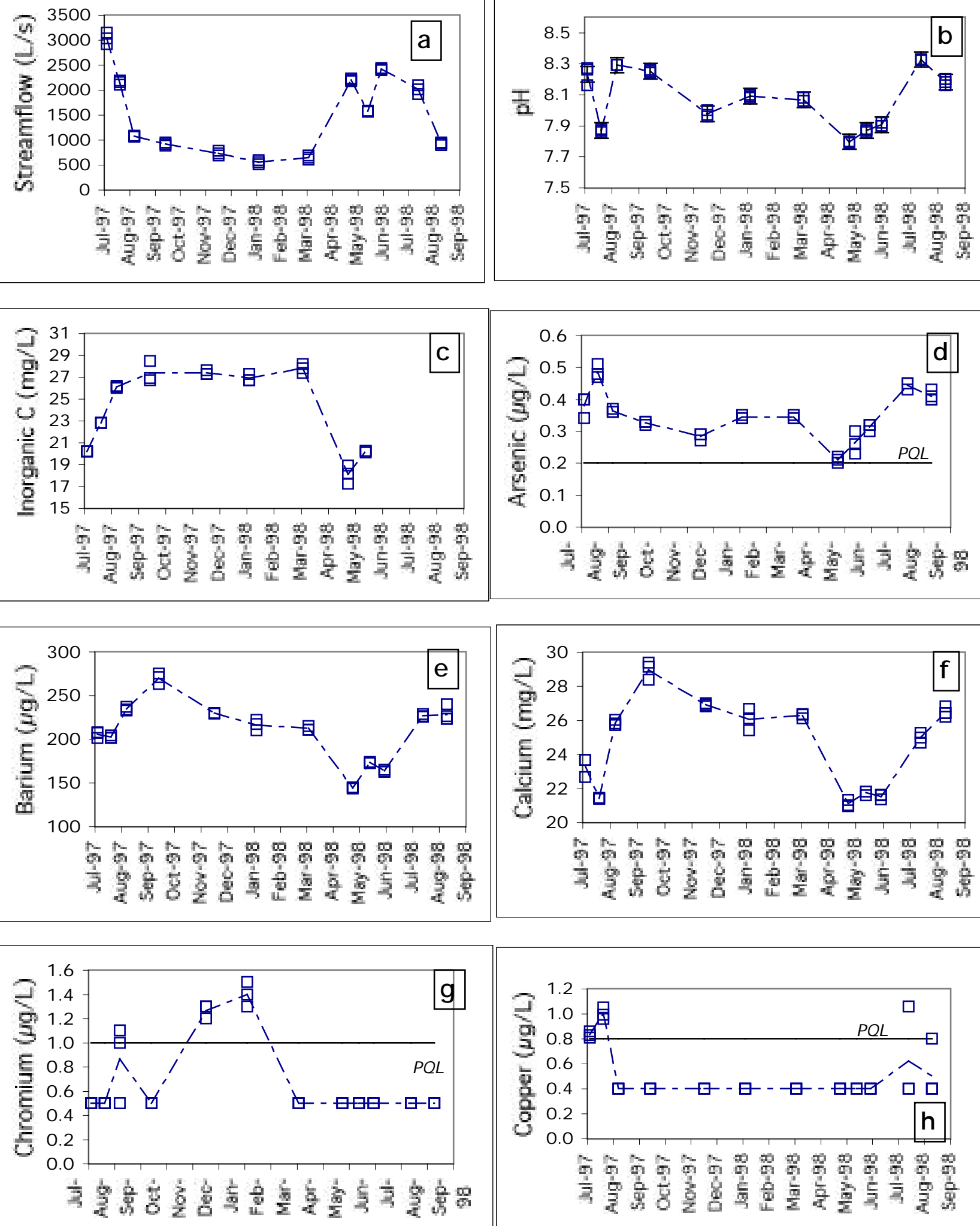
Figure 18i-18p: Trends over time at Blackfoot River site "BH"
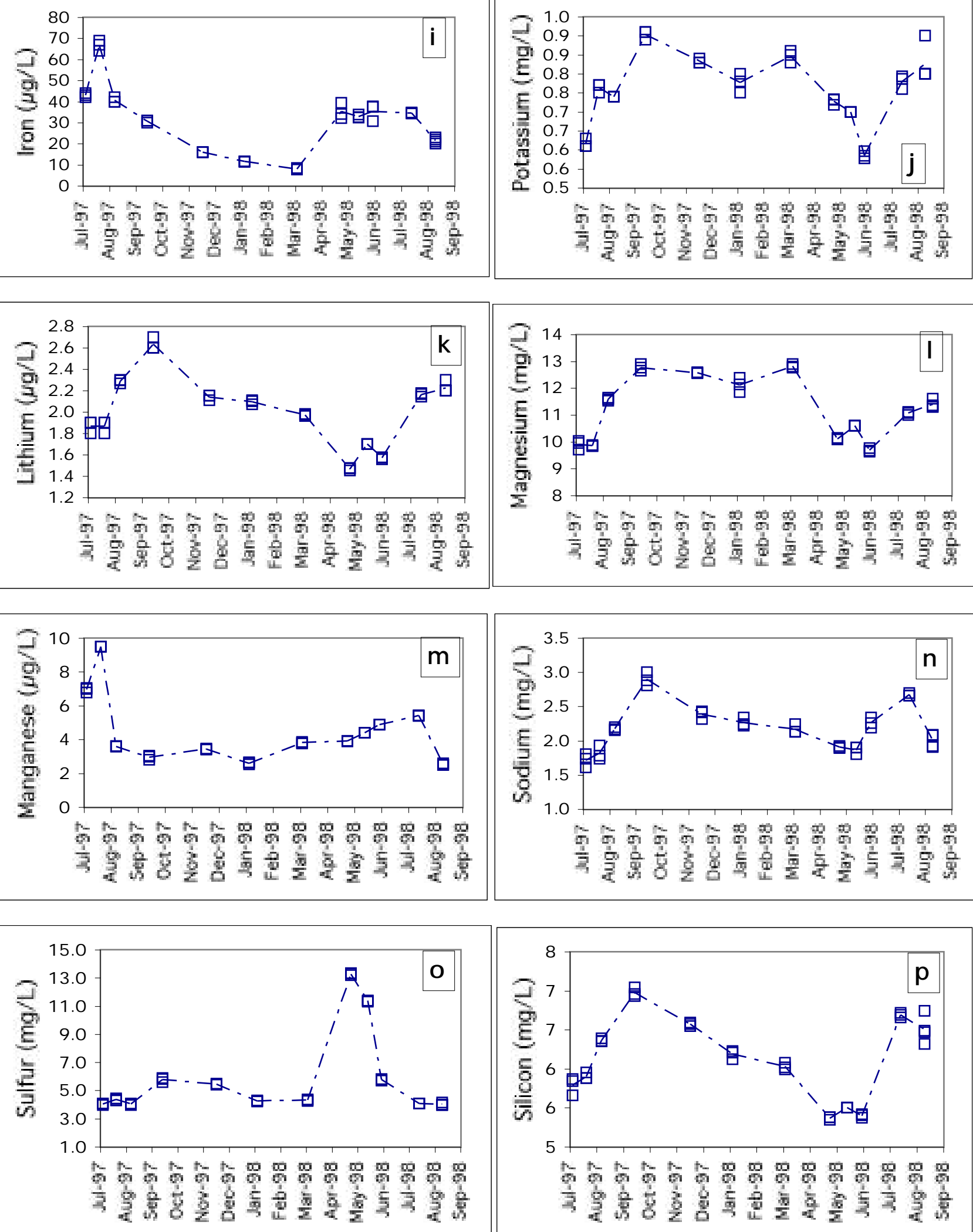
Figure 18q-18r: Trends over time at Blackfoot River site "BH"
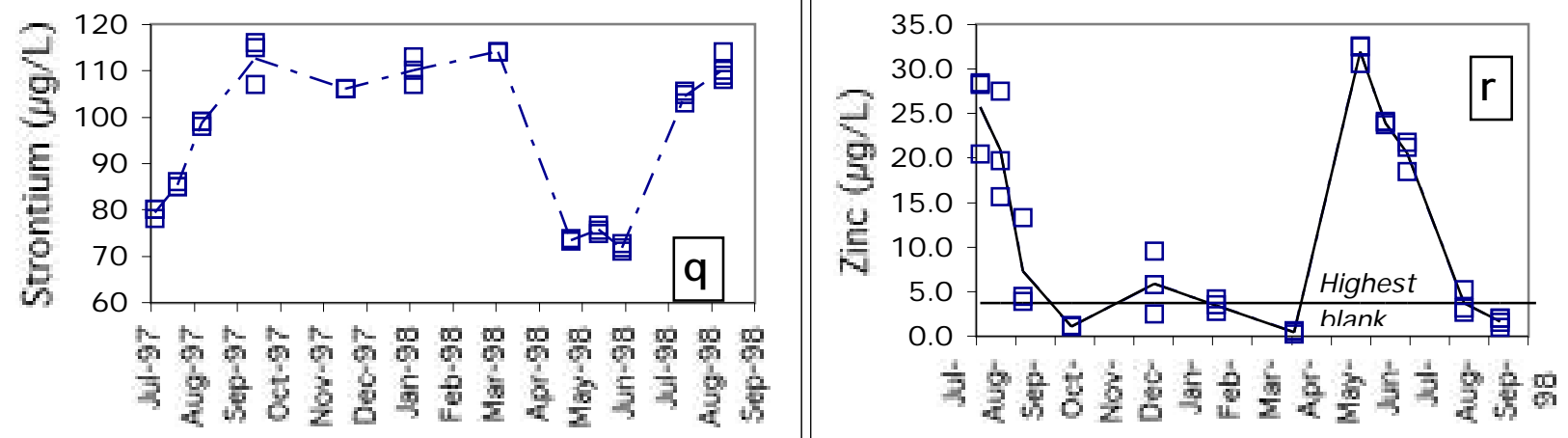
Figure 19a: Inorganic carbon, $\mathrm{Ca}$, and Mg loads at site $\mathrm{BH}$

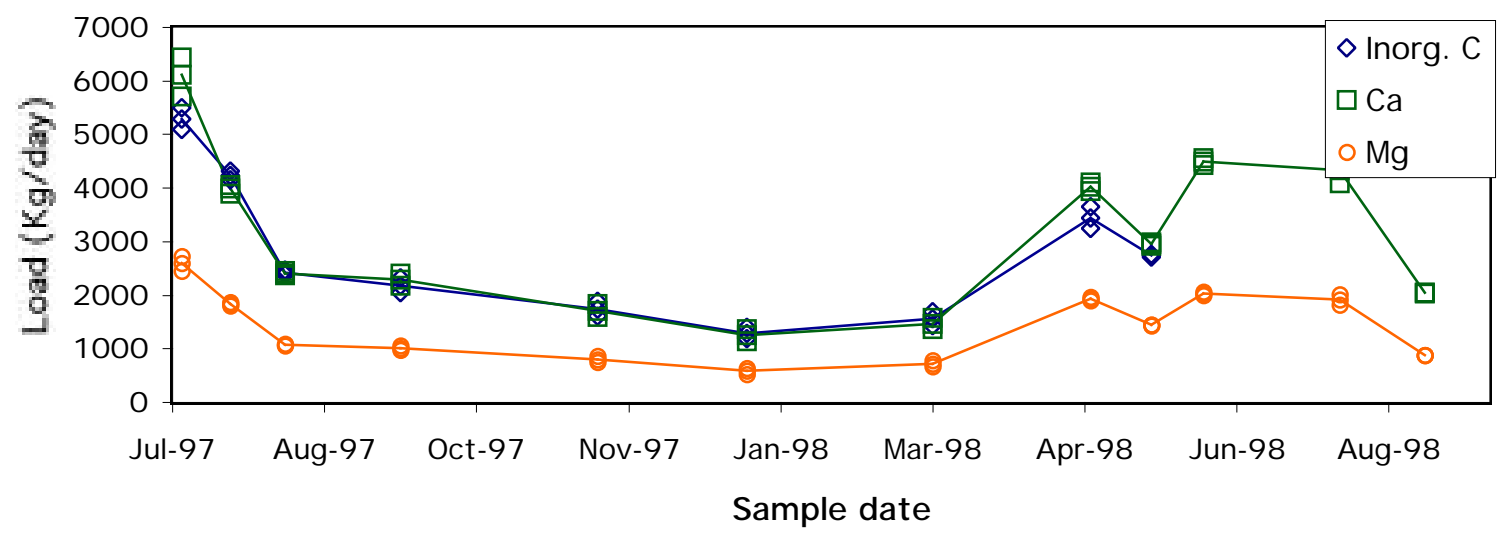

Figure 19b: $\mathrm{As}, \mathrm{Cr}, \mathrm{Cu}$, and Li loads at site $\mathrm{BH}$

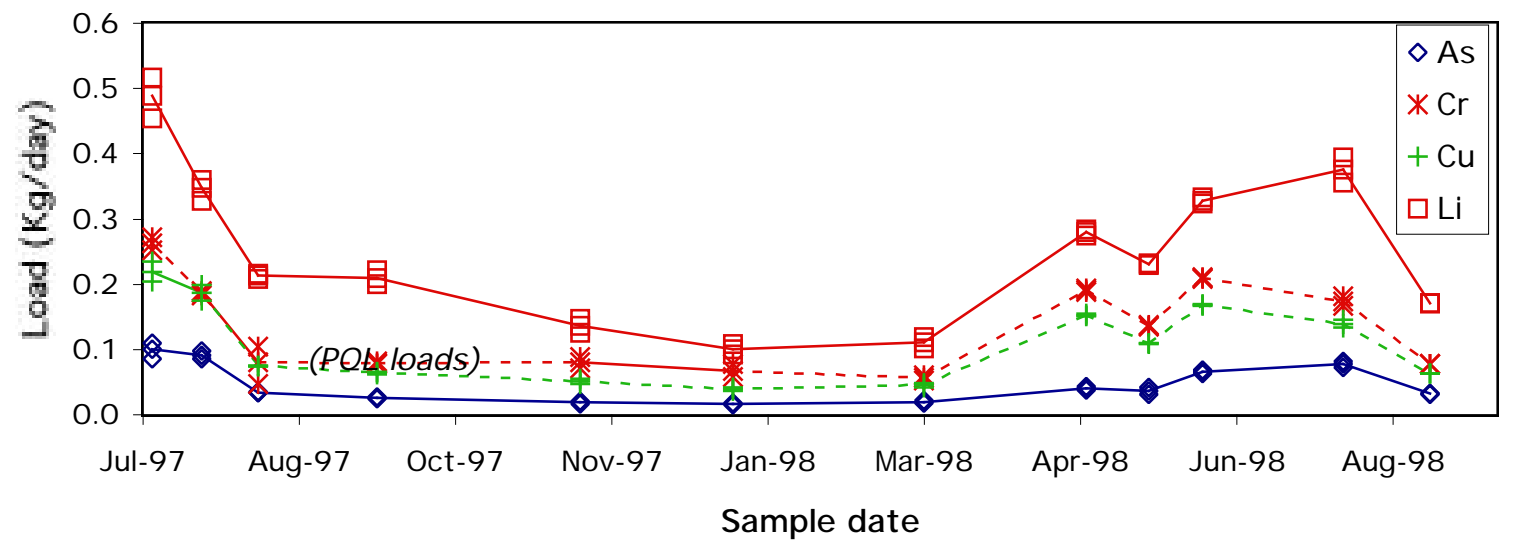

Figure 19c: Ba, Fe, $\mathrm{K}$, and Sr loads at site BH

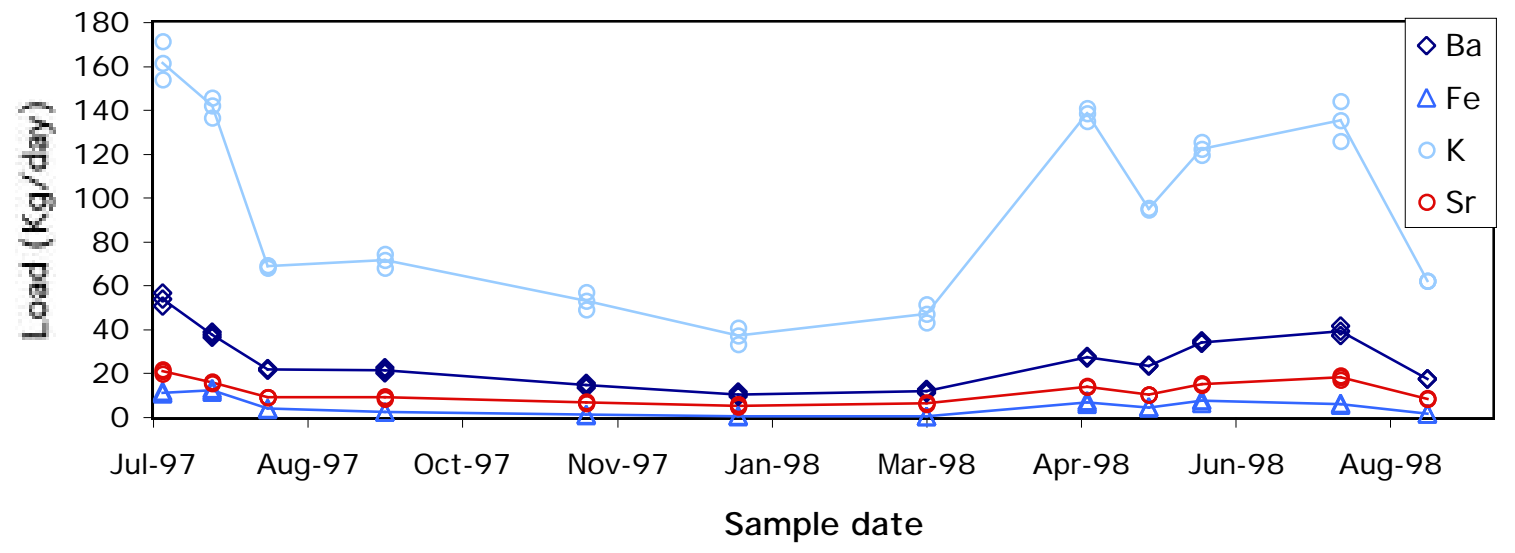


Figure 19d: $\mathrm{Mn}$ and $\mathrm{Zn}$ loads at site BH

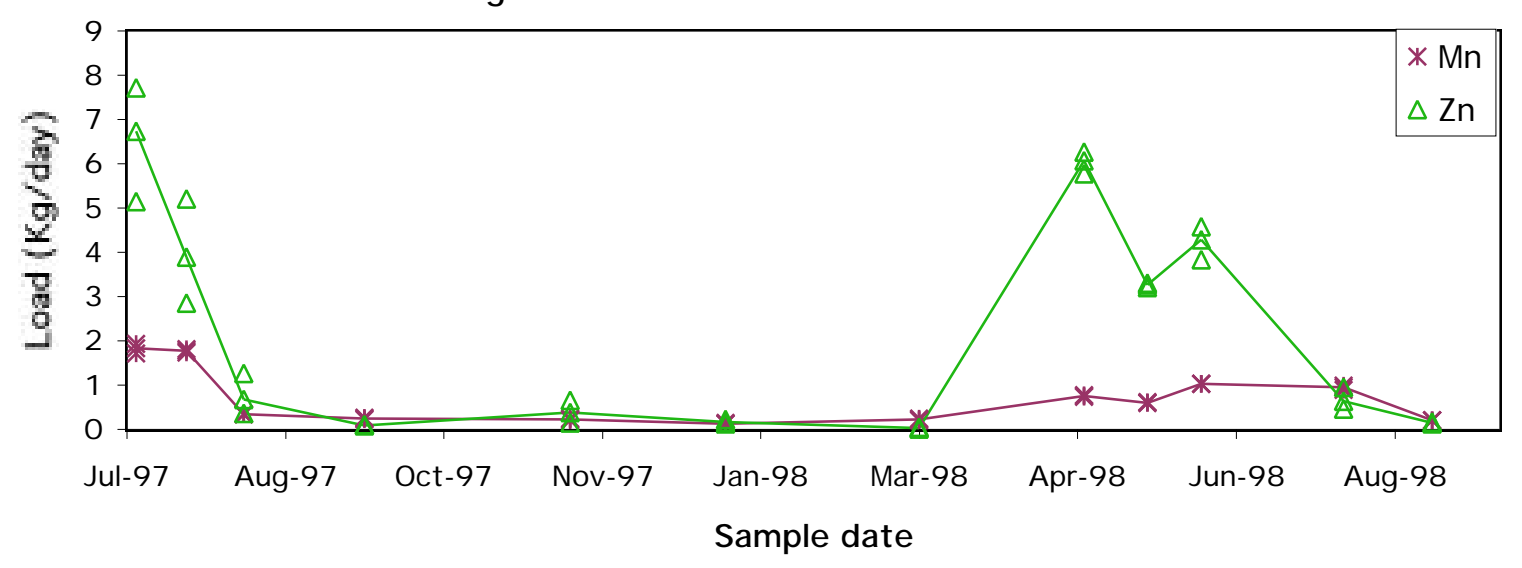

Figure 19e: $\mathrm{Na}, \mathrm{S}$, and $\mathrm{Si}$ loads at site $\mathrm{BH}$

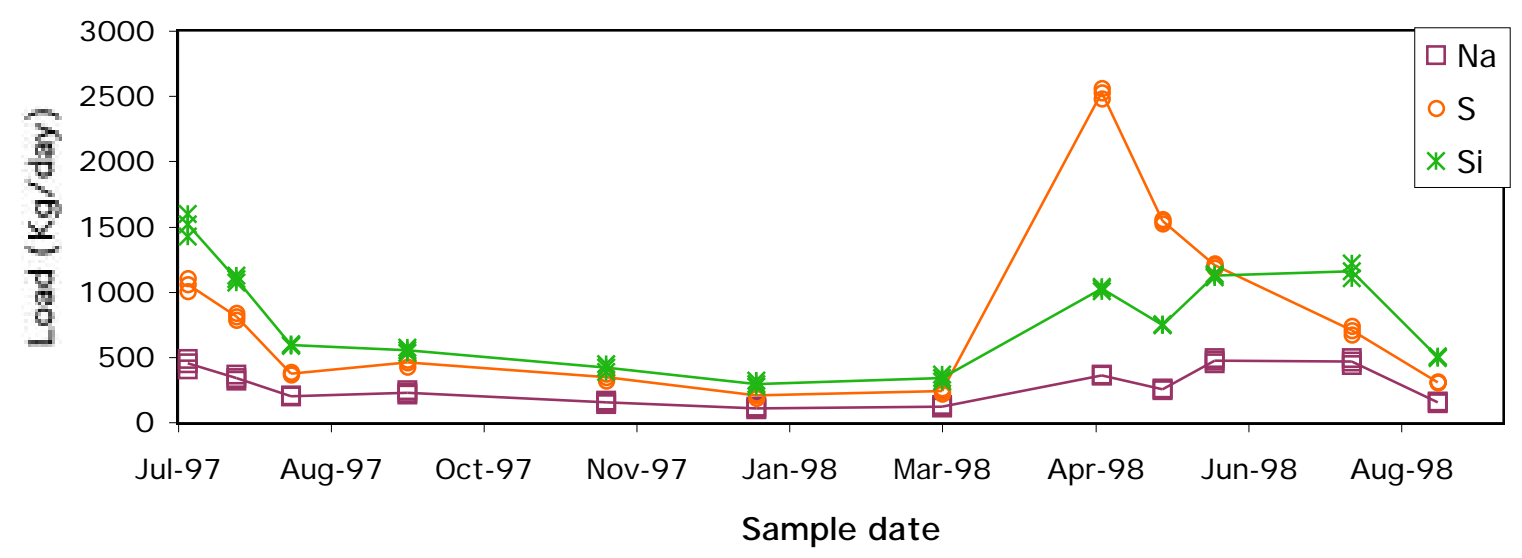


Figures 20a-20h: Streamflow vs. concentrations at Hogum Creek, site "HC"
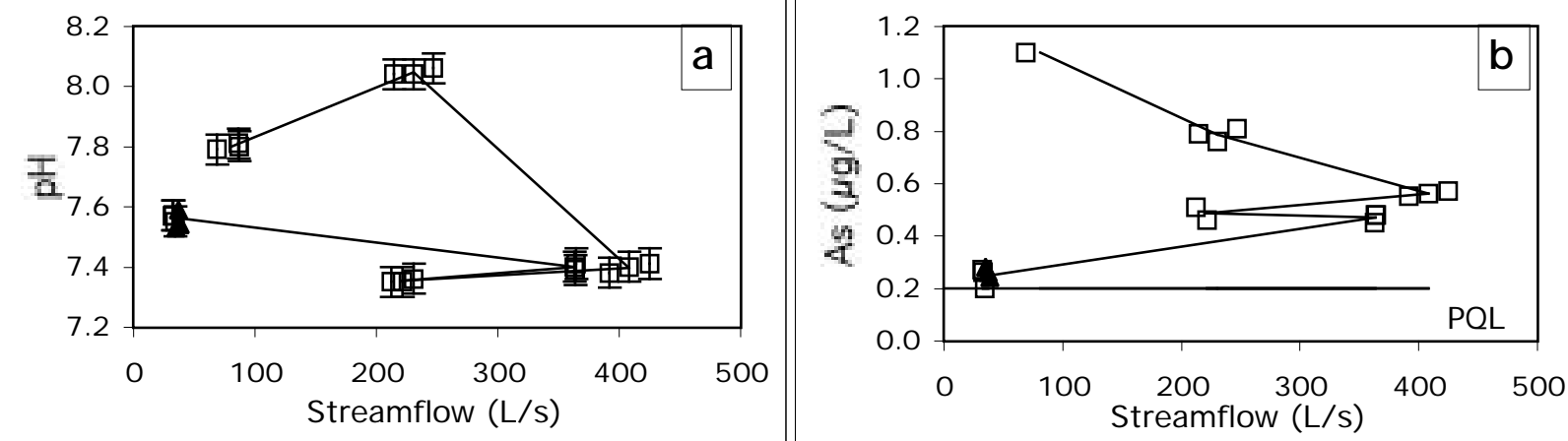

Triangles indicate the first sampling event, on 11/18/97
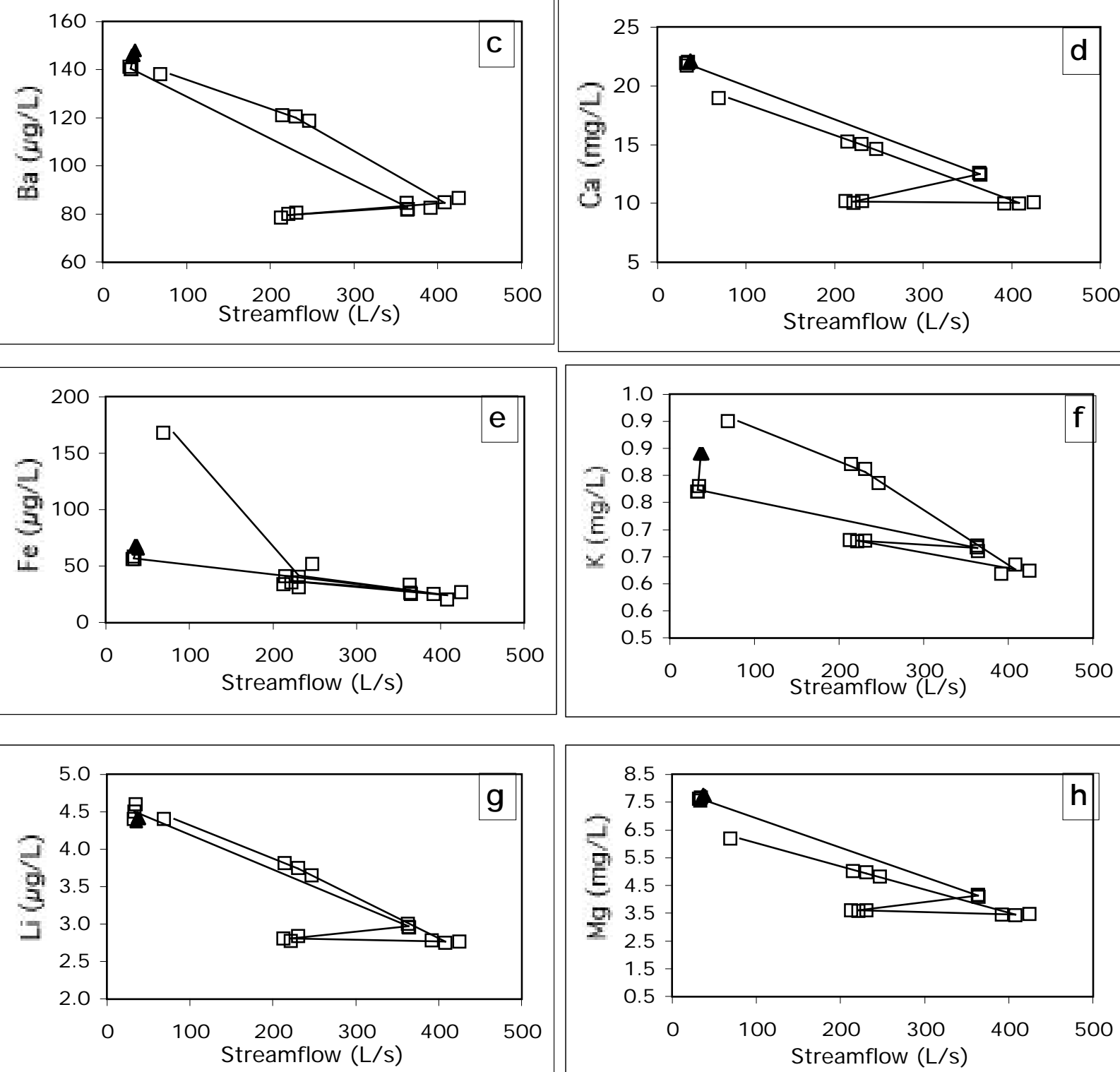
Figures 20i-20m: Streamflow vs. concentrations at Hogum Creek, site "HC"
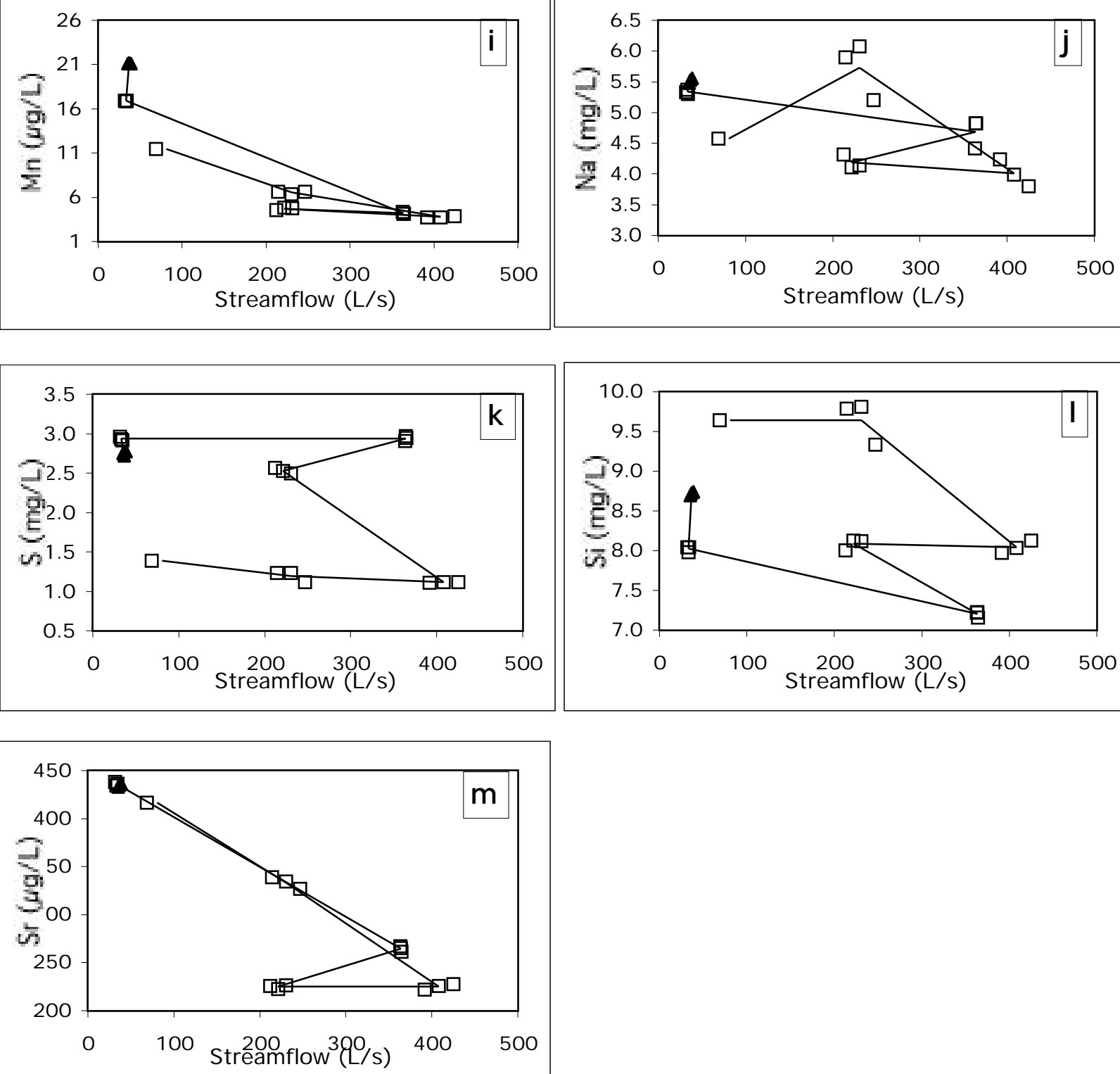
Figures 21a-21h: Trends over time at Hogum Creek, site "HC"
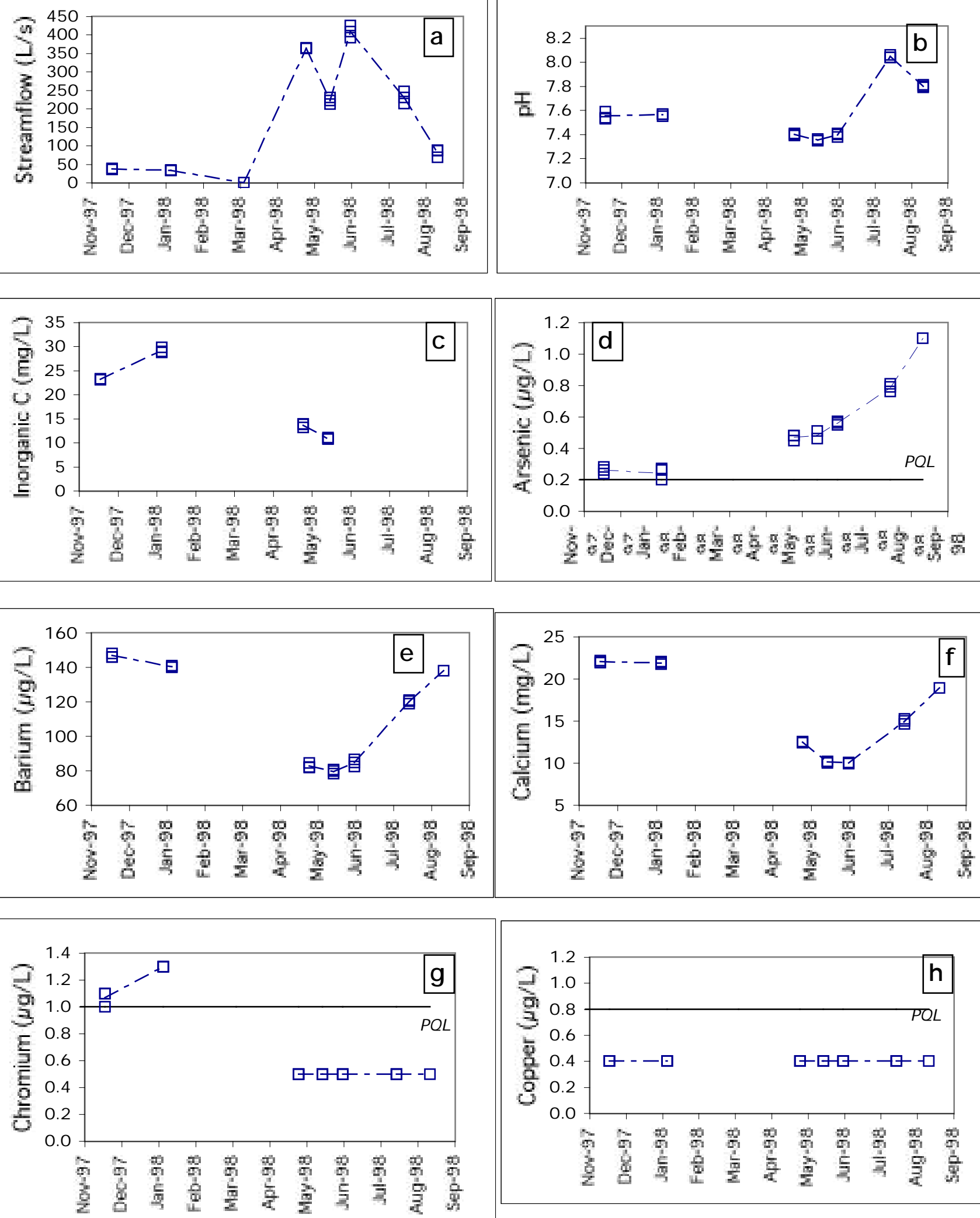
Figures 21i-21l: Trends over time at Hogum Creek, site "HC"
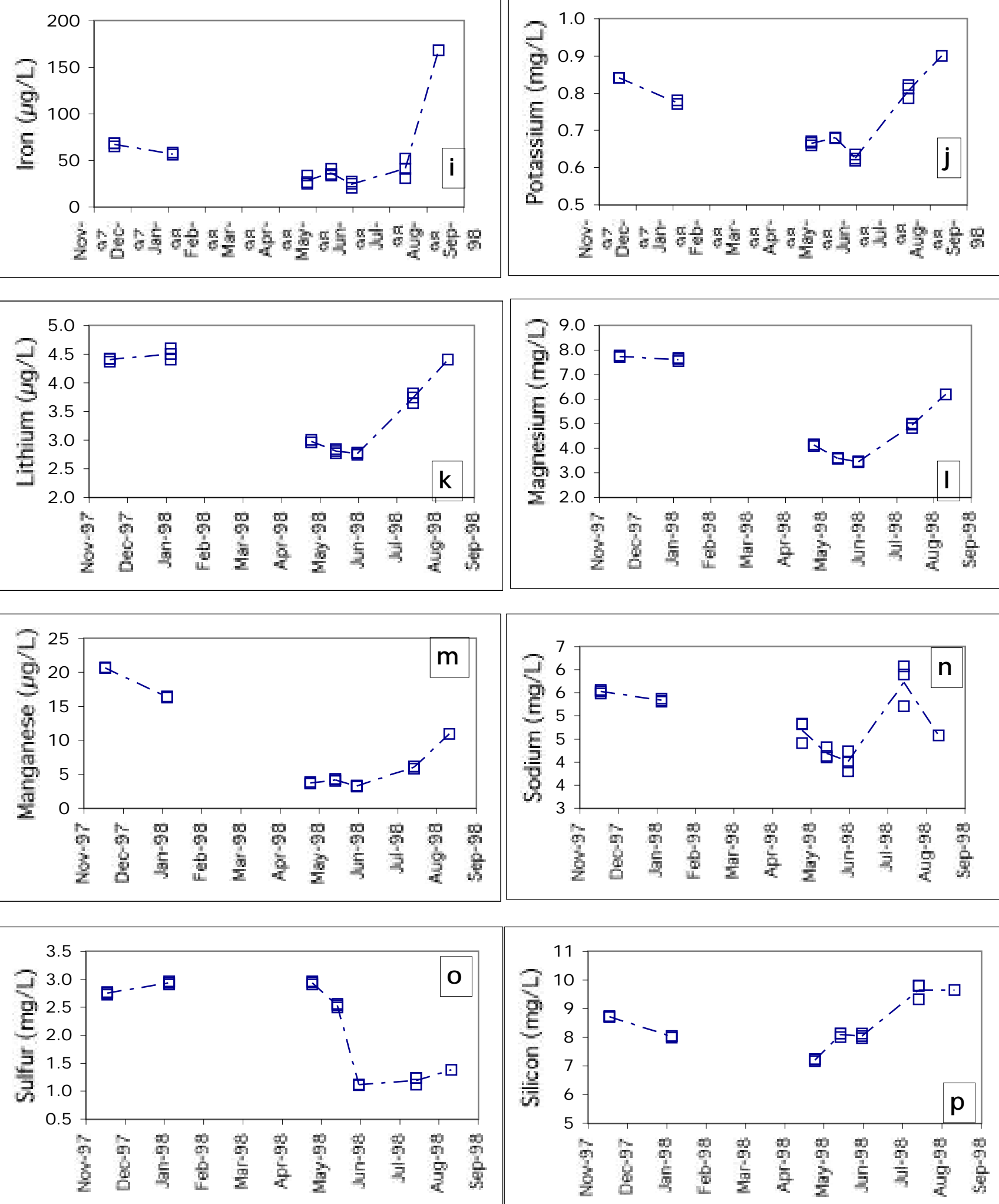
Figures 21q-21r: Trends over time at Hogum Creek, site "HC"

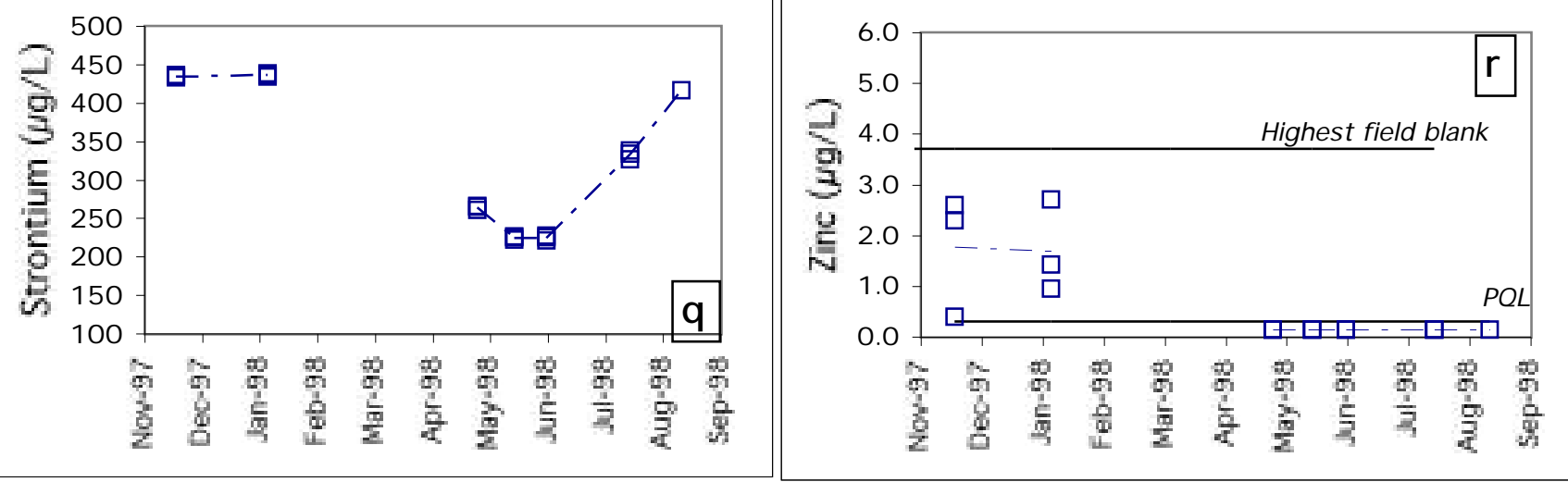


Figure 22a: Inorganic carbon, $\mathrm{Ca}$, and $\mathrm{Mg}$ loads at site HC

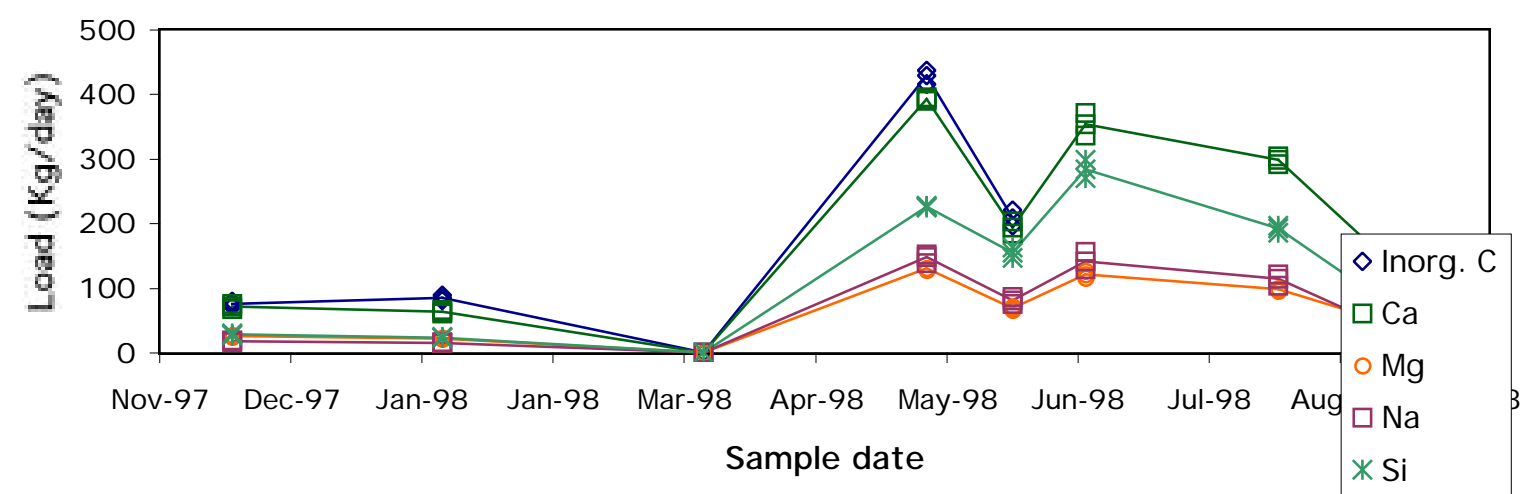

Figure $22 \mathrm{~b}$ : As and $\mathrm{Cr}$ loads at site HC

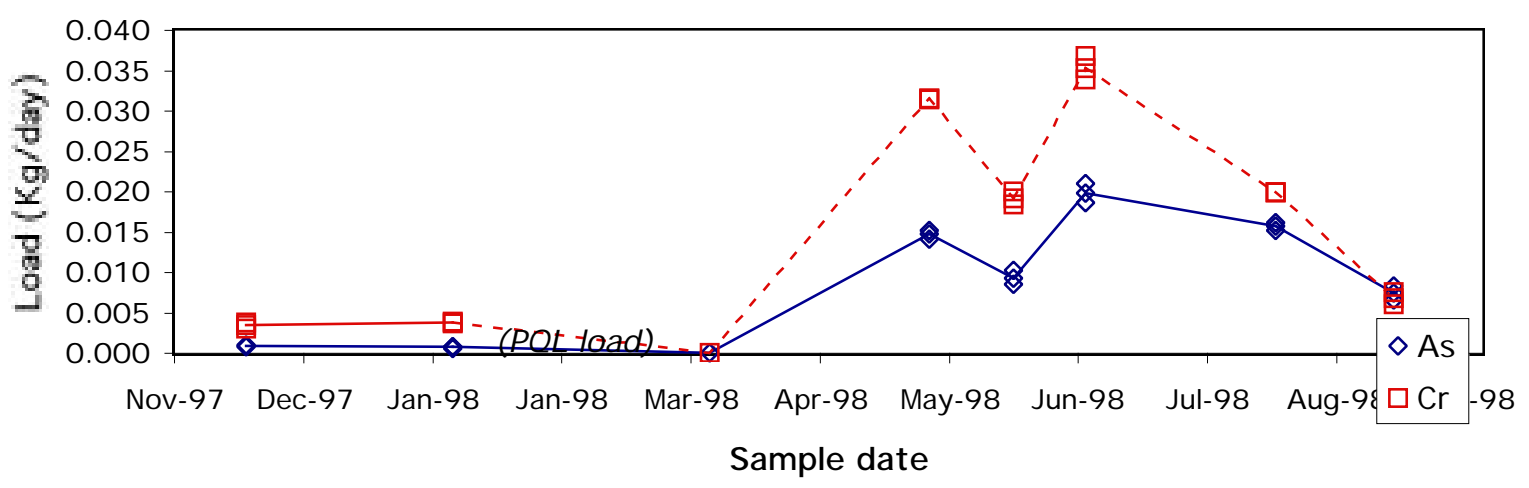

Figure 22c: Li and Mn loads at site HC

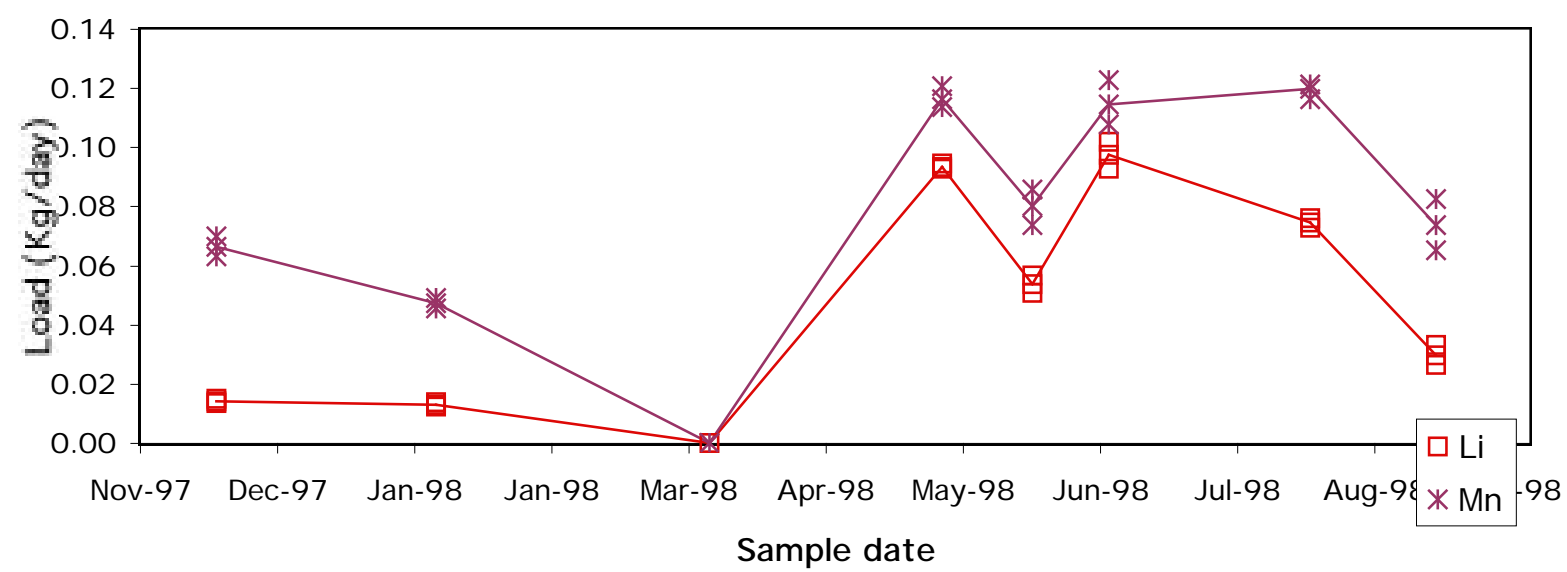


Figure 22d: Ba, Fe, and Sr loads at site HC

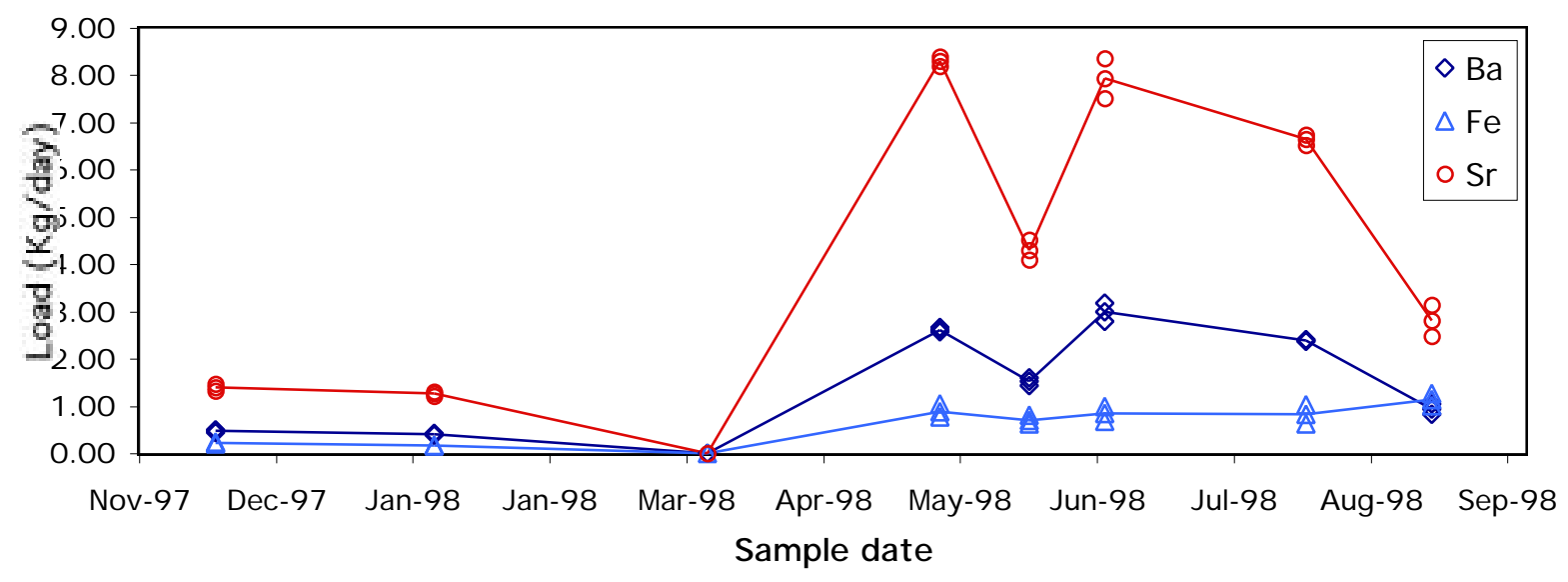

Figure 22e: $\mathrm{K}$ and $\mathrm{S}$ loads at site HC

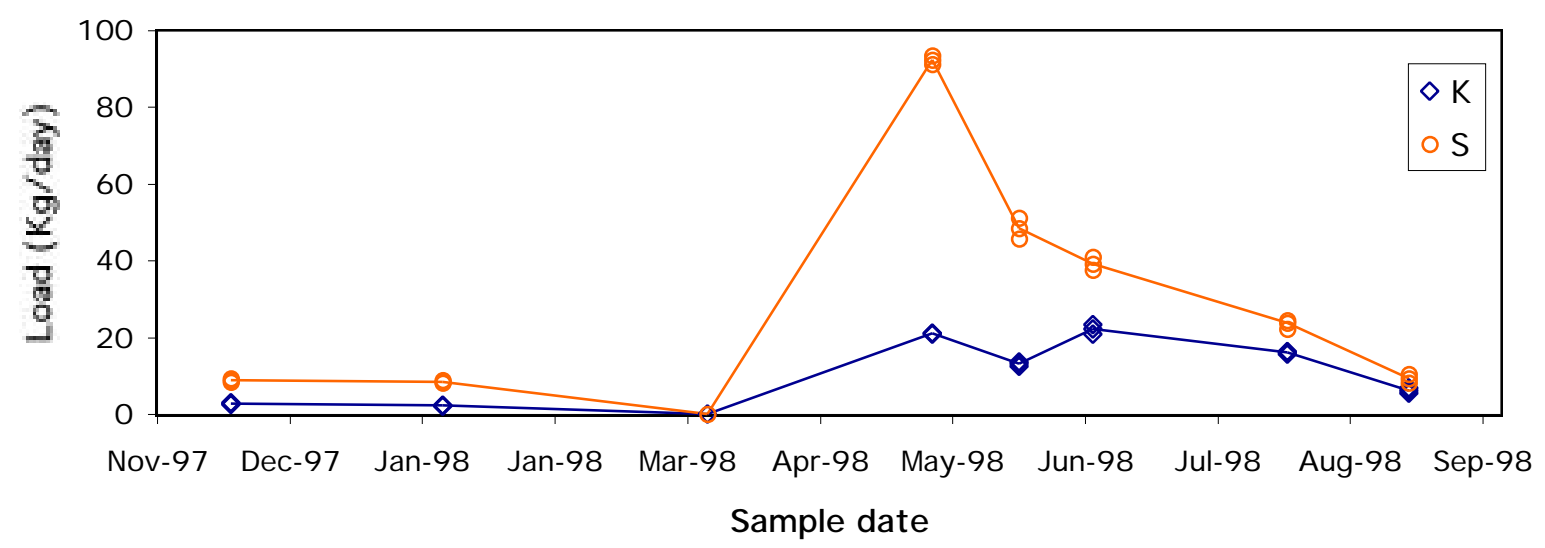


Figures 23a-23h: Streamflow vs. concentrations at Blackfoot site "BB"
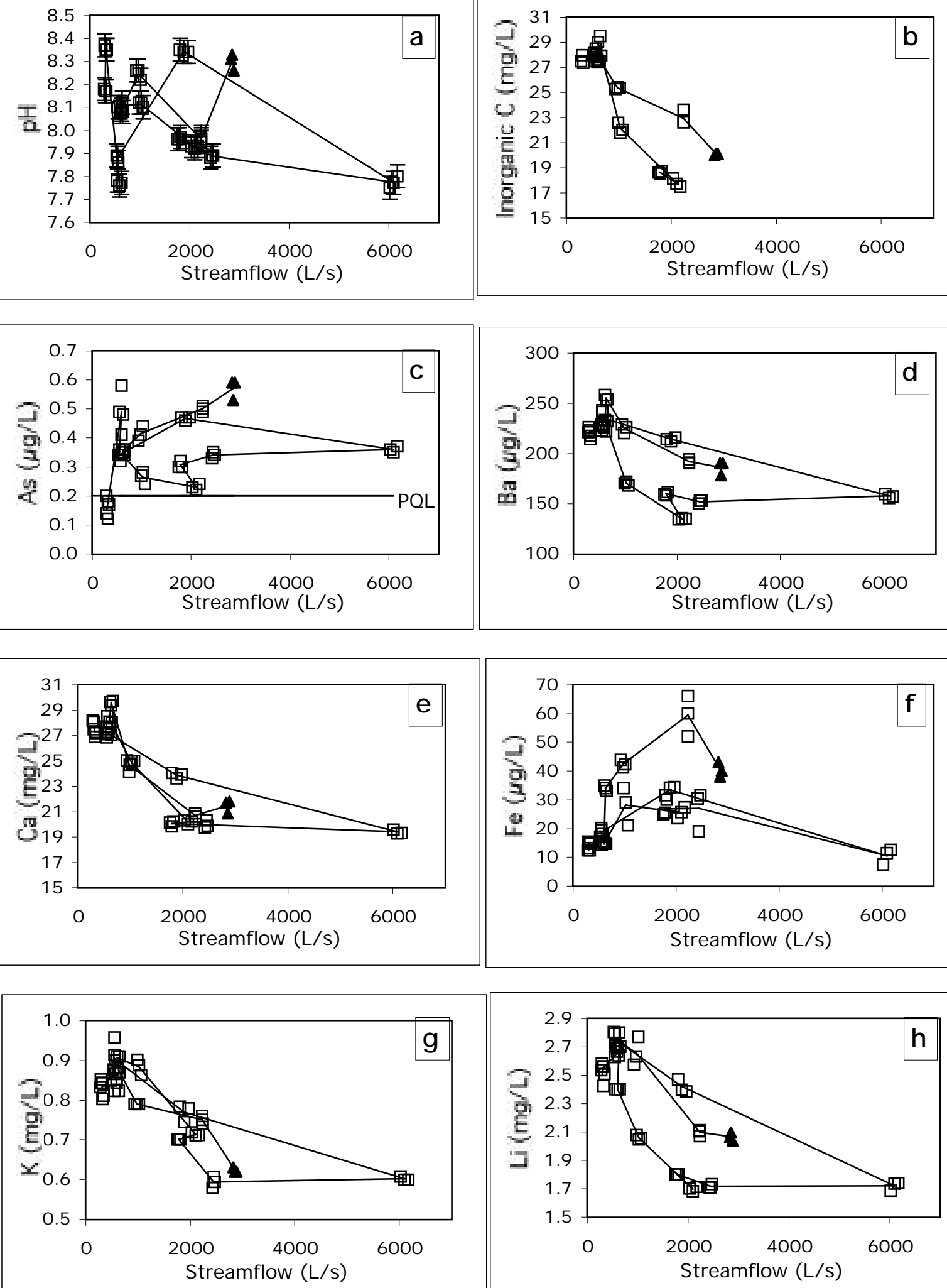
Figures 23i-23o: Streamflow vs. concentrations at Blackfoot site "BB"
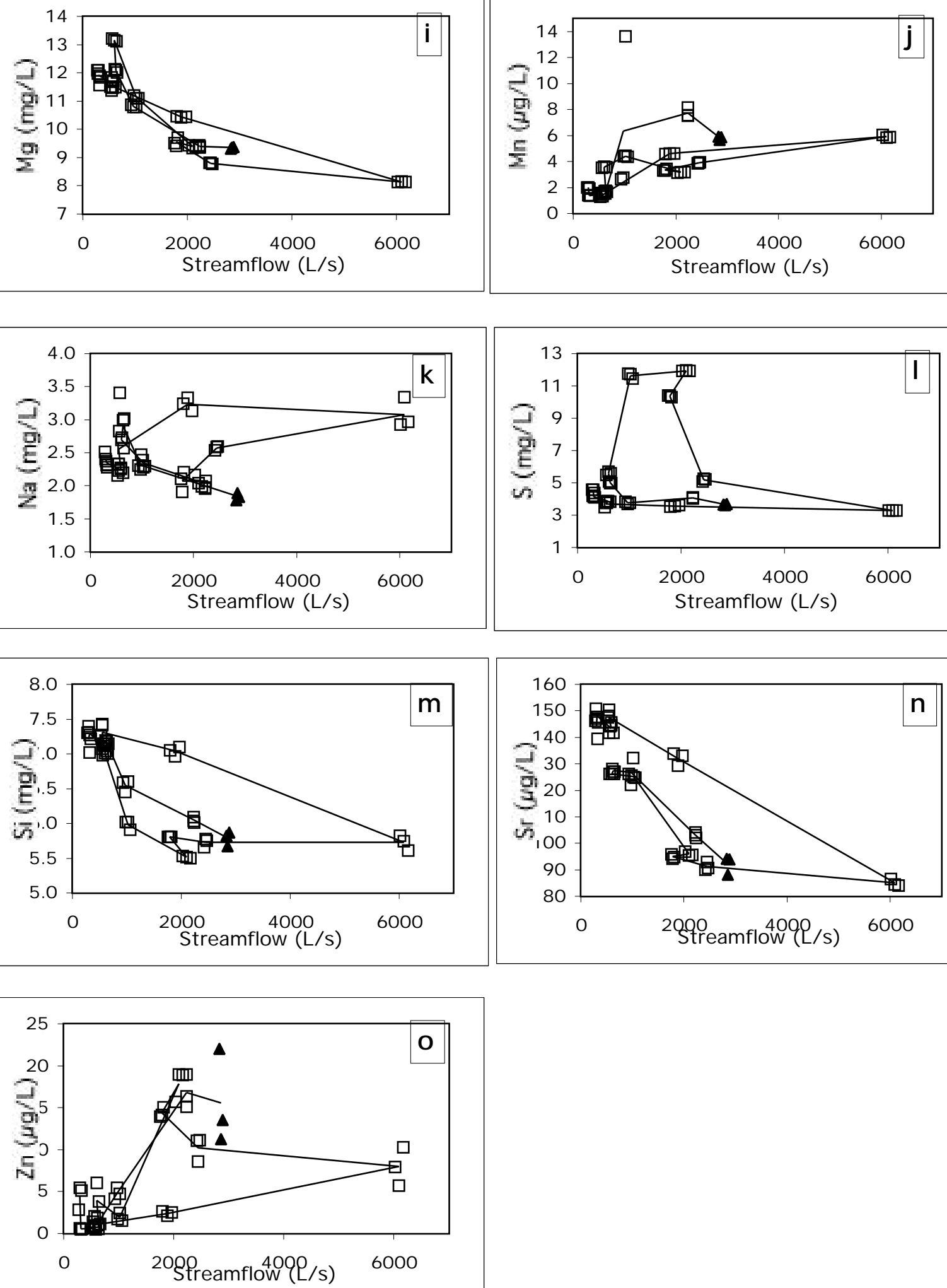
Figures 24a-24h: Trends over time at Blackfoot River site "BB"
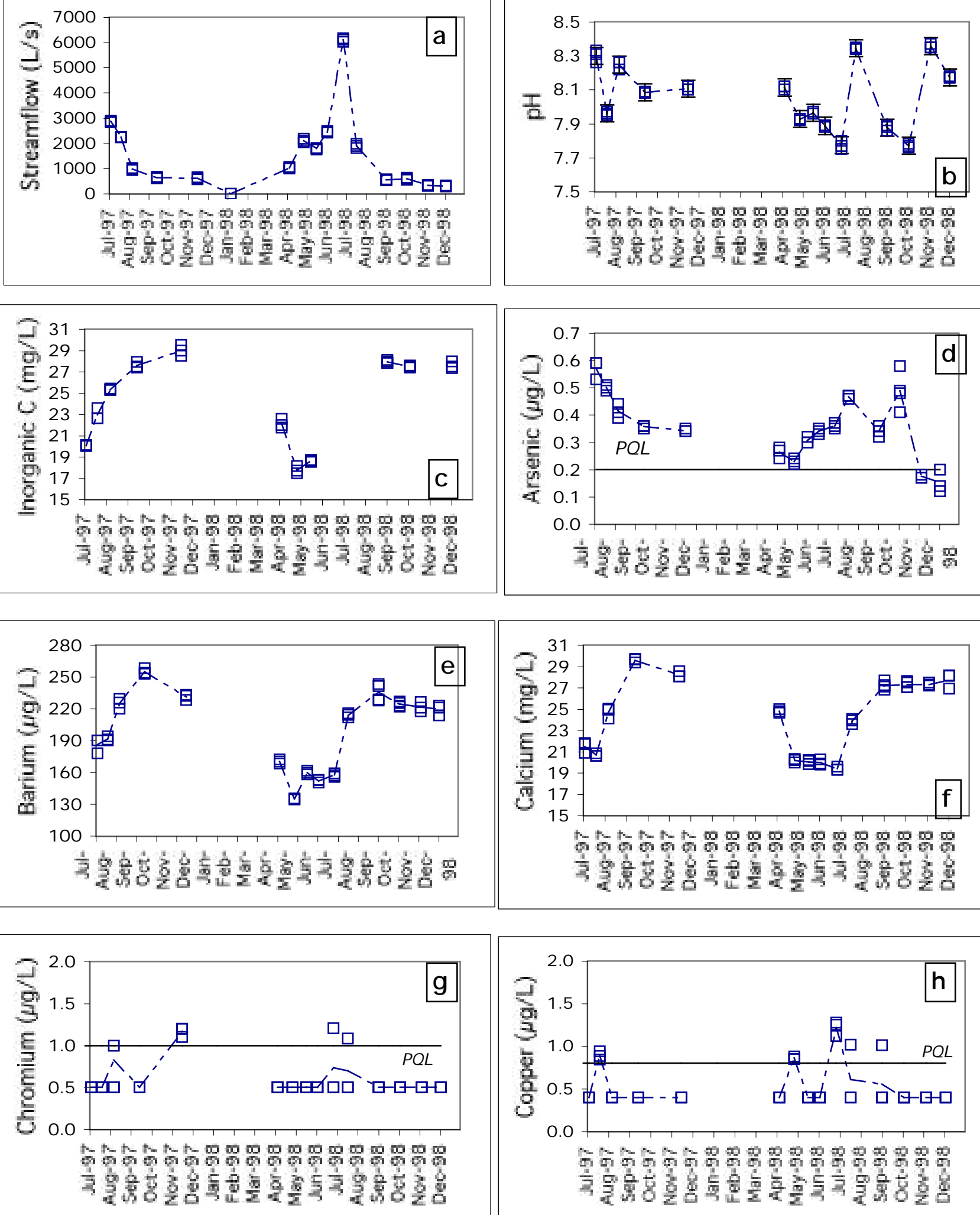
Figures 24i-24p: Trends over time at Blackfoot River site "BB"
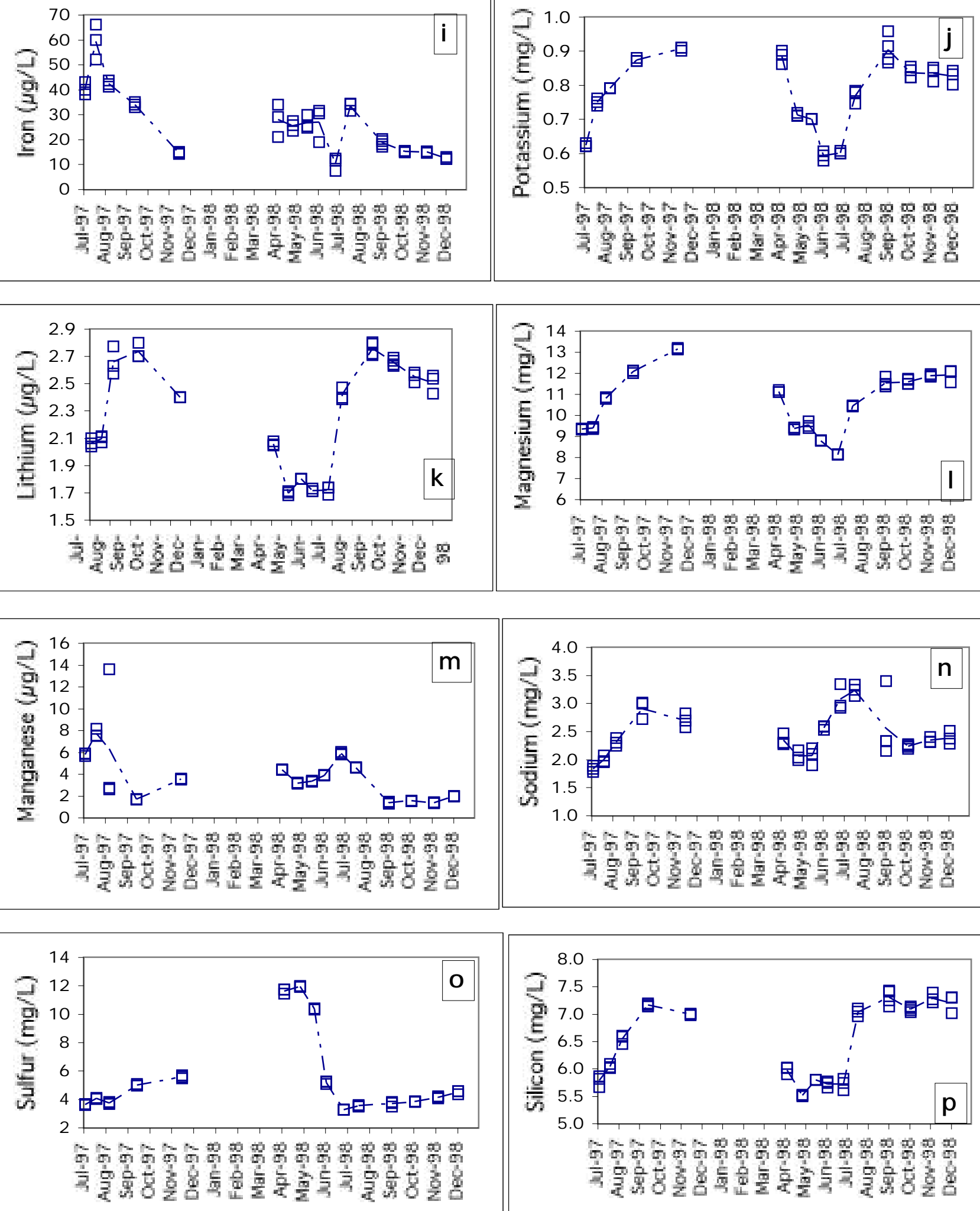
Figures 24q-24r: Trends over time at Blackfoot River site "BB"
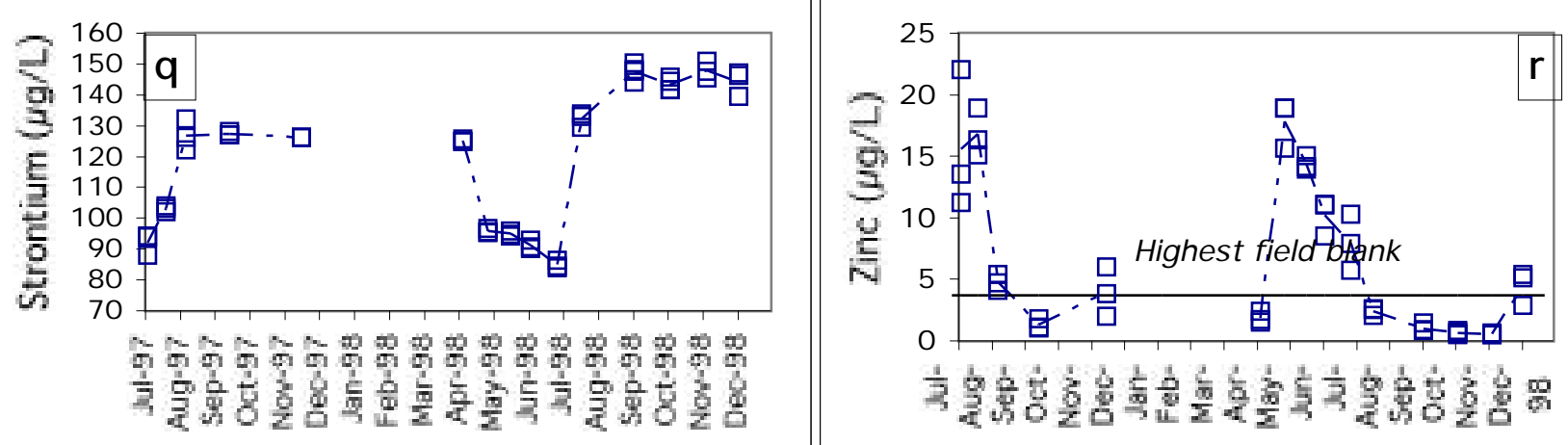
Figure 25a: Inorganic carbon, $\mathrm{Ca}$, and Mg loads at site BB

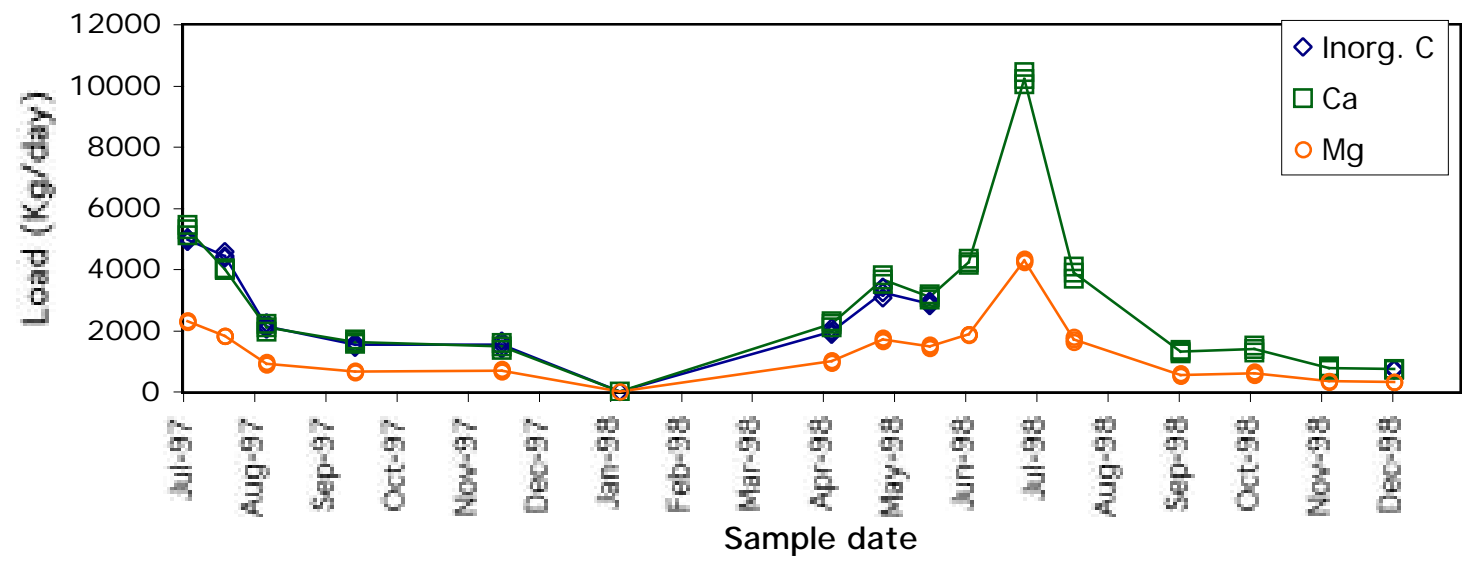

Figure 25b: $\mathrm{As}, \mathrm{Cr}, \mathrm{Cu}$, and $\mathrm{Li}$ loads at site $\mathrm{BB}$

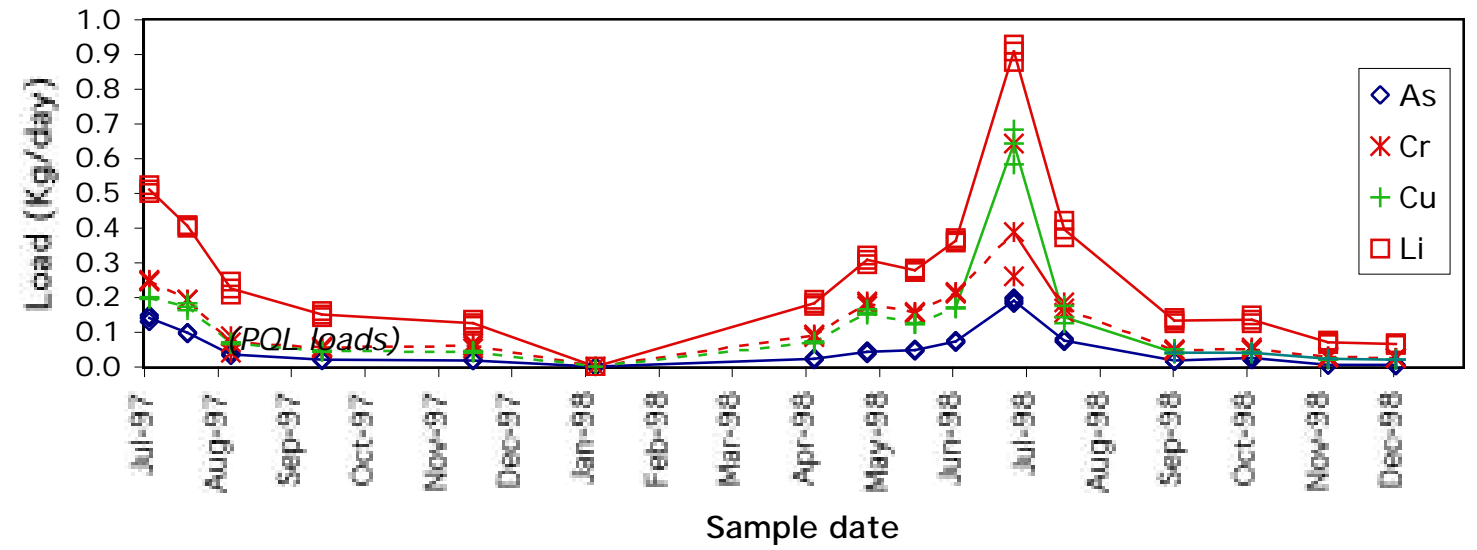

Figure 25c: $\mathrm{Ba}, \mathrm{Fe}, \mathrm{K}$, and $\mathrm{Sr}$ loads at site BB

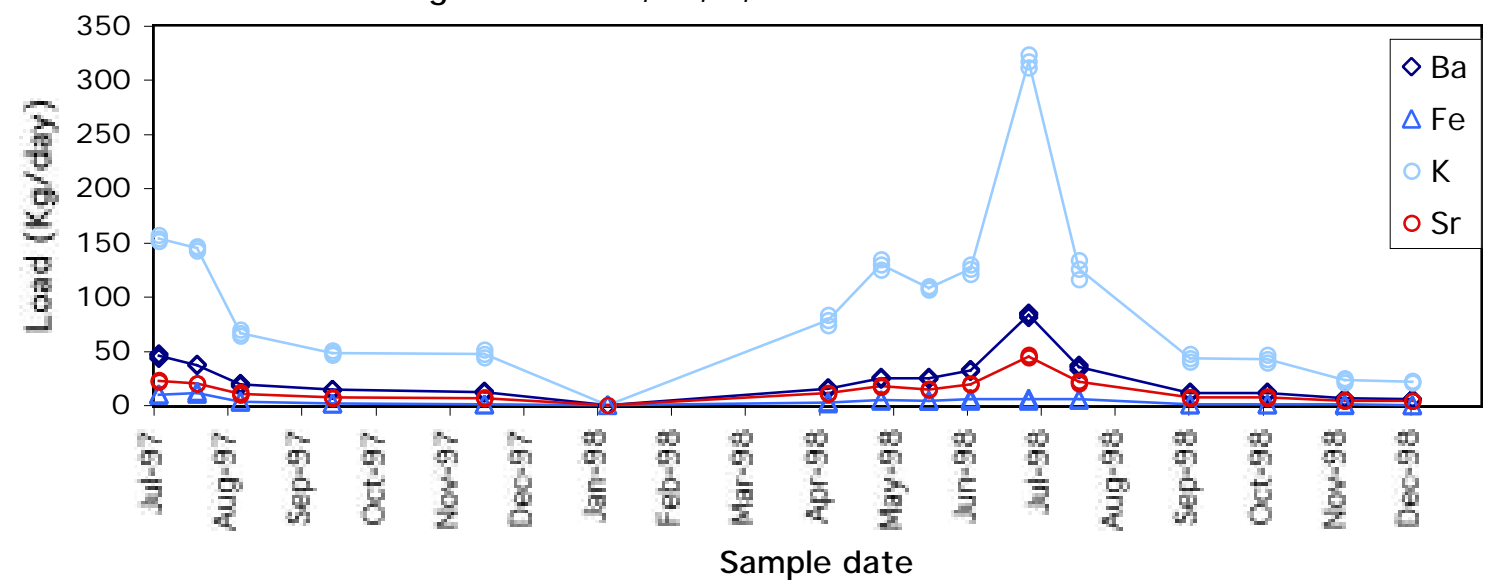


Figure 25d: $\mathrm{Mn}$ and $\mathrm{Zn}$ loads at site BB

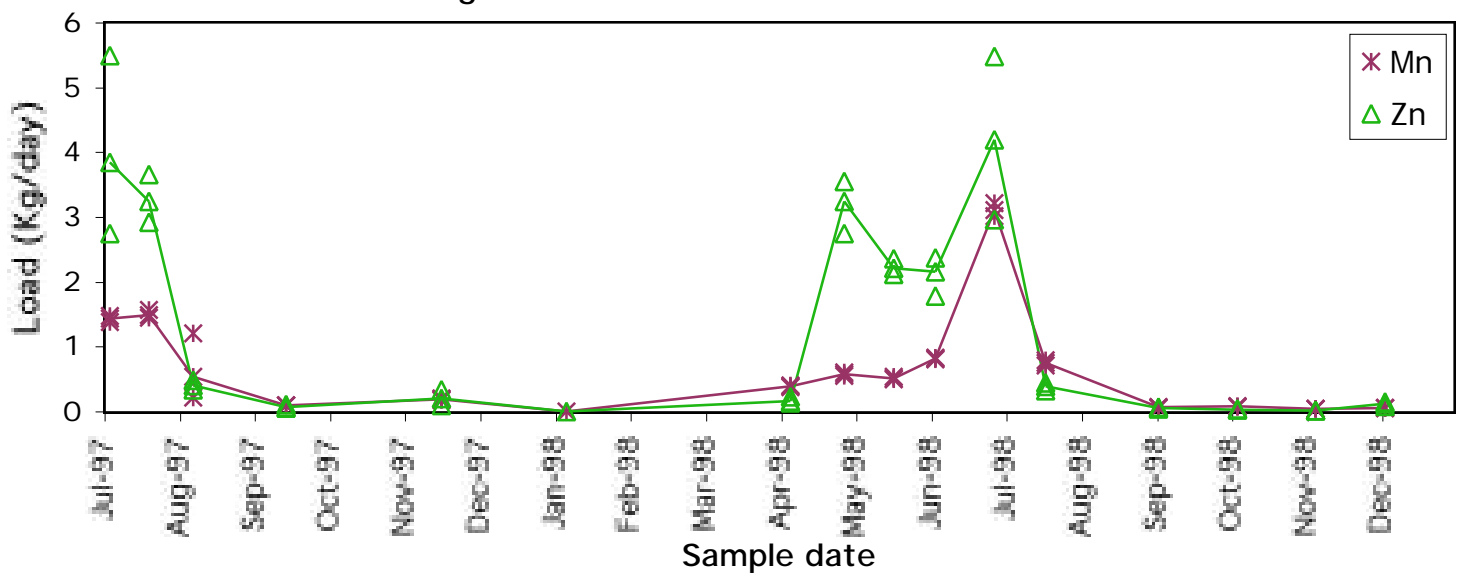

Figure 25e: $\mathrm{Na}, \mathrm{S}$, and $\mathrm{Si}$ loads at site BB

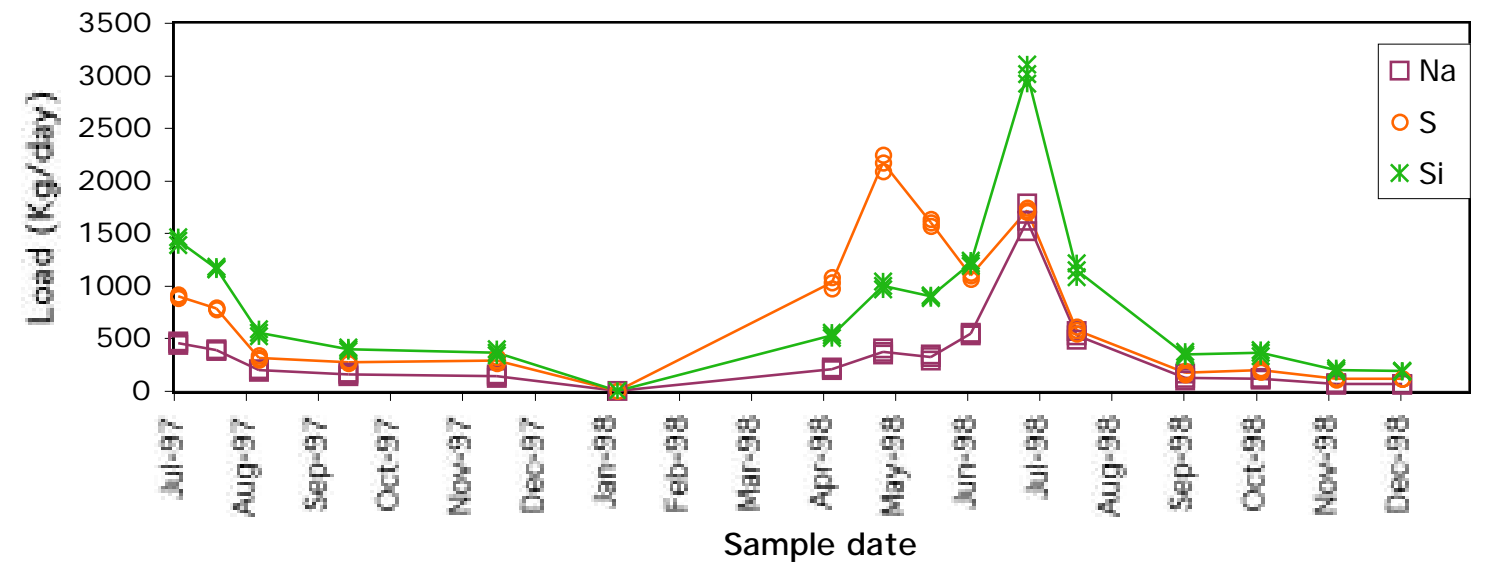


Figures 26a-26h: Streamflow vs. concentrations at Blackfoot site "BC"
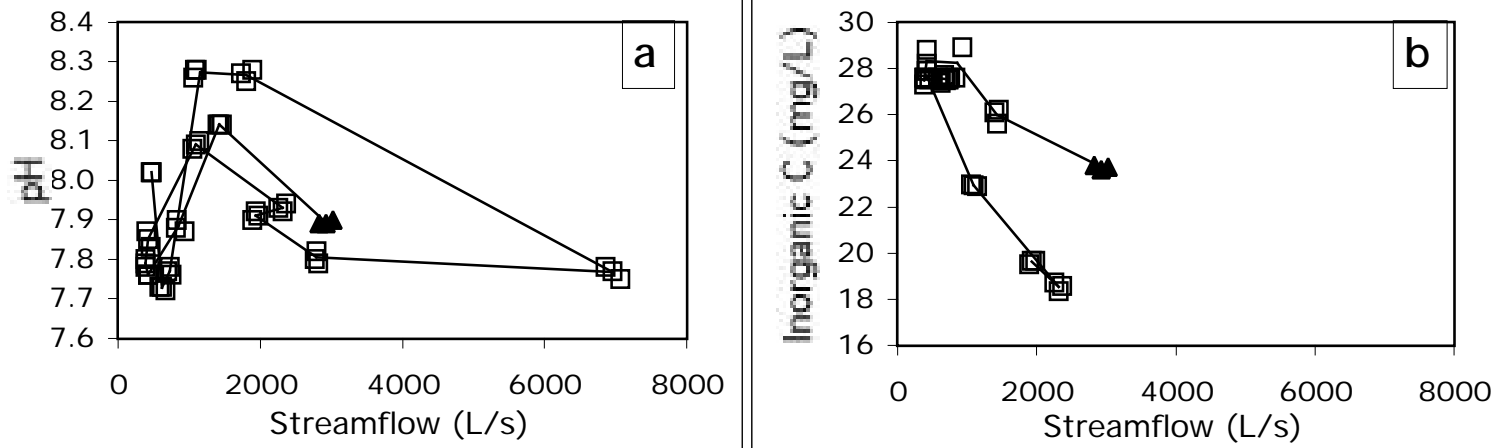

Triangles indicate the first sampling event, on $7 / 20 / 97$
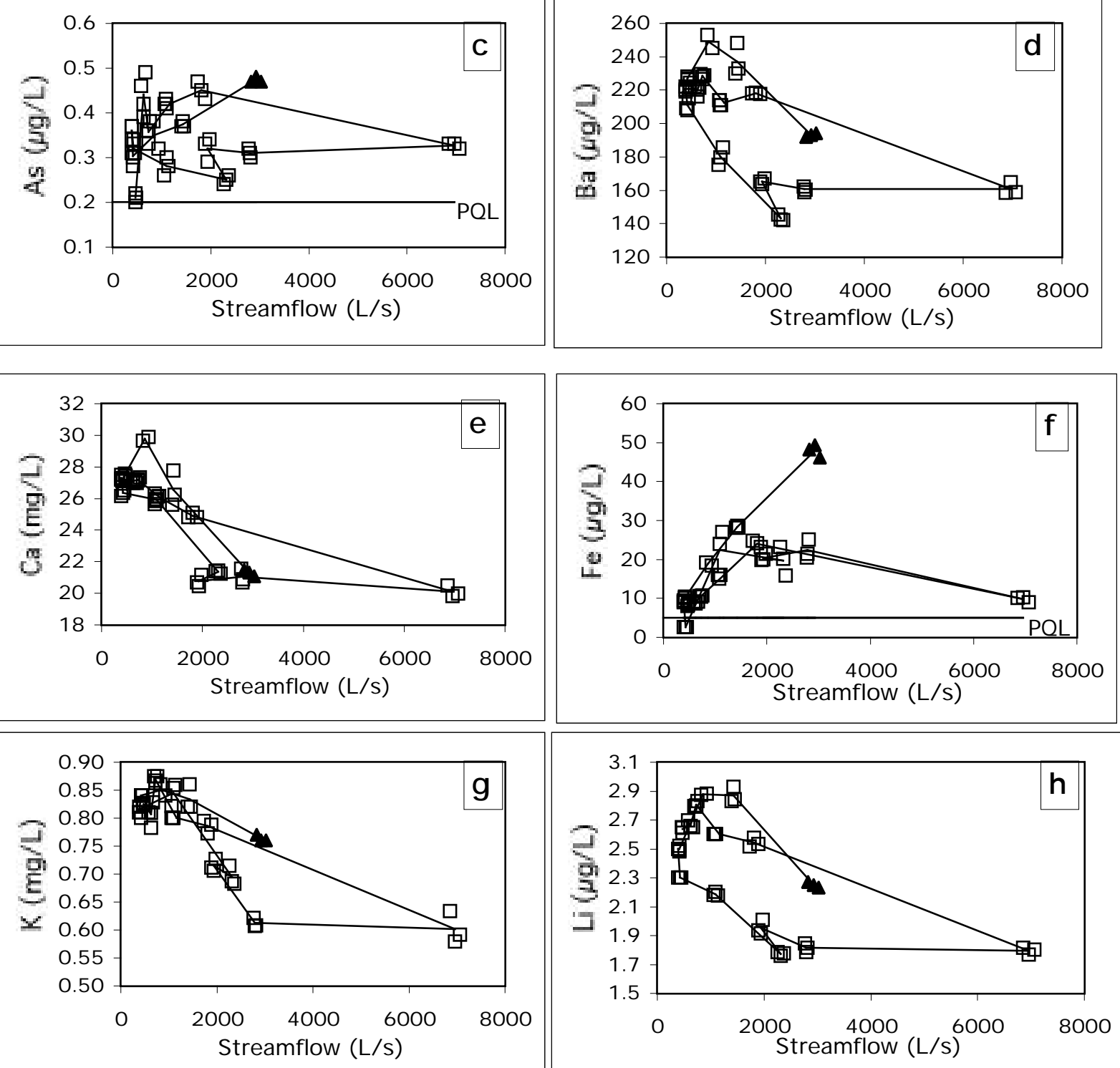
Figures 26i-26o: Streamflow vs. concentrations at Blackfoot site "BC"
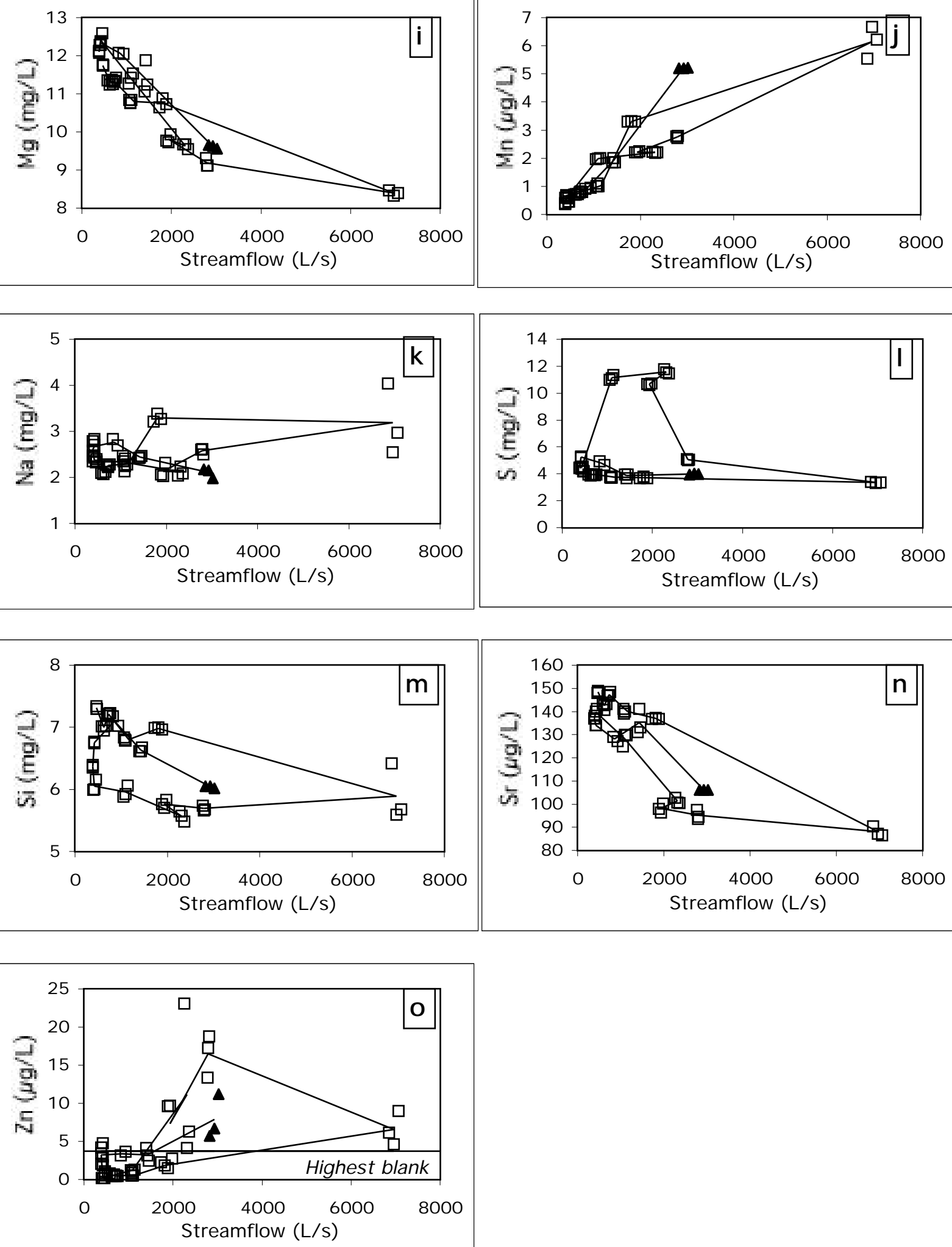
Figures 27a-27h: Trends over time at Blackfoot River site "BC"

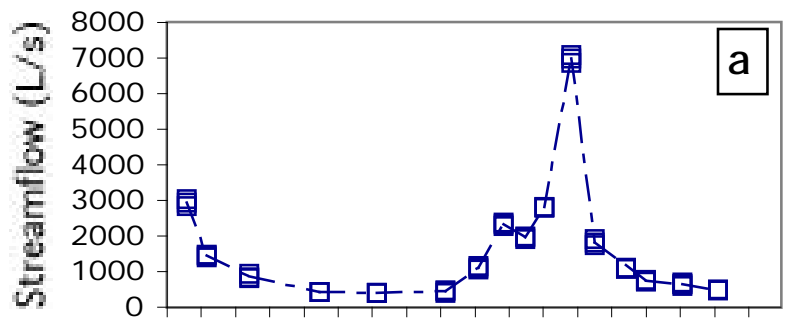

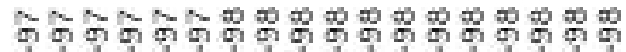

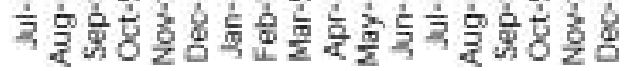
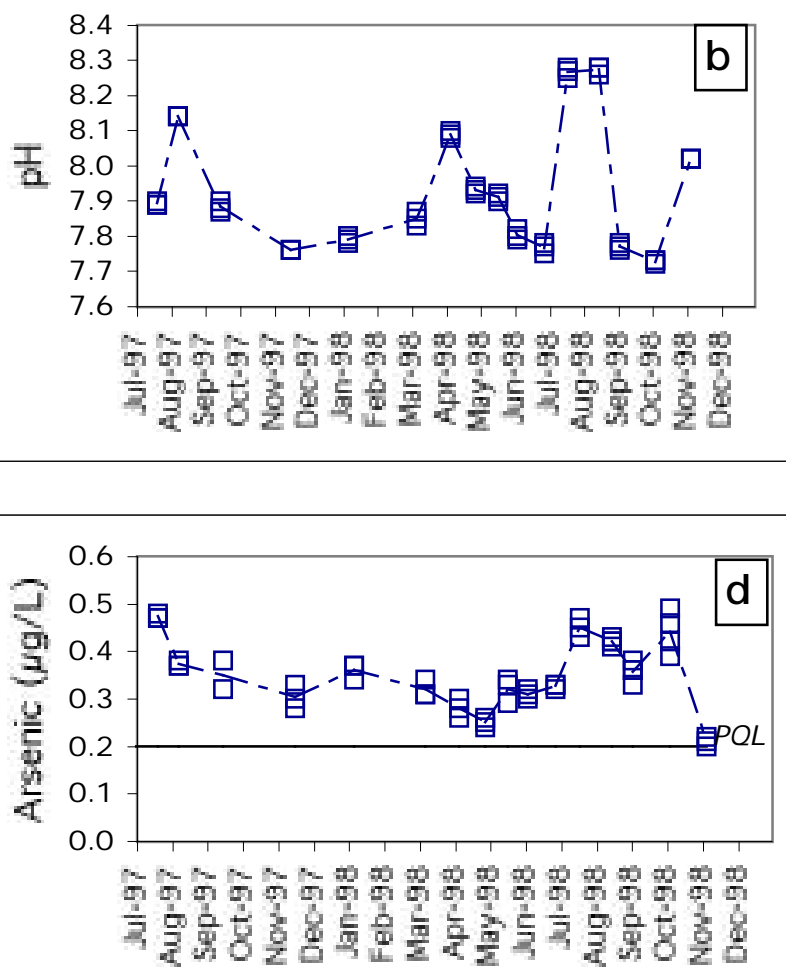
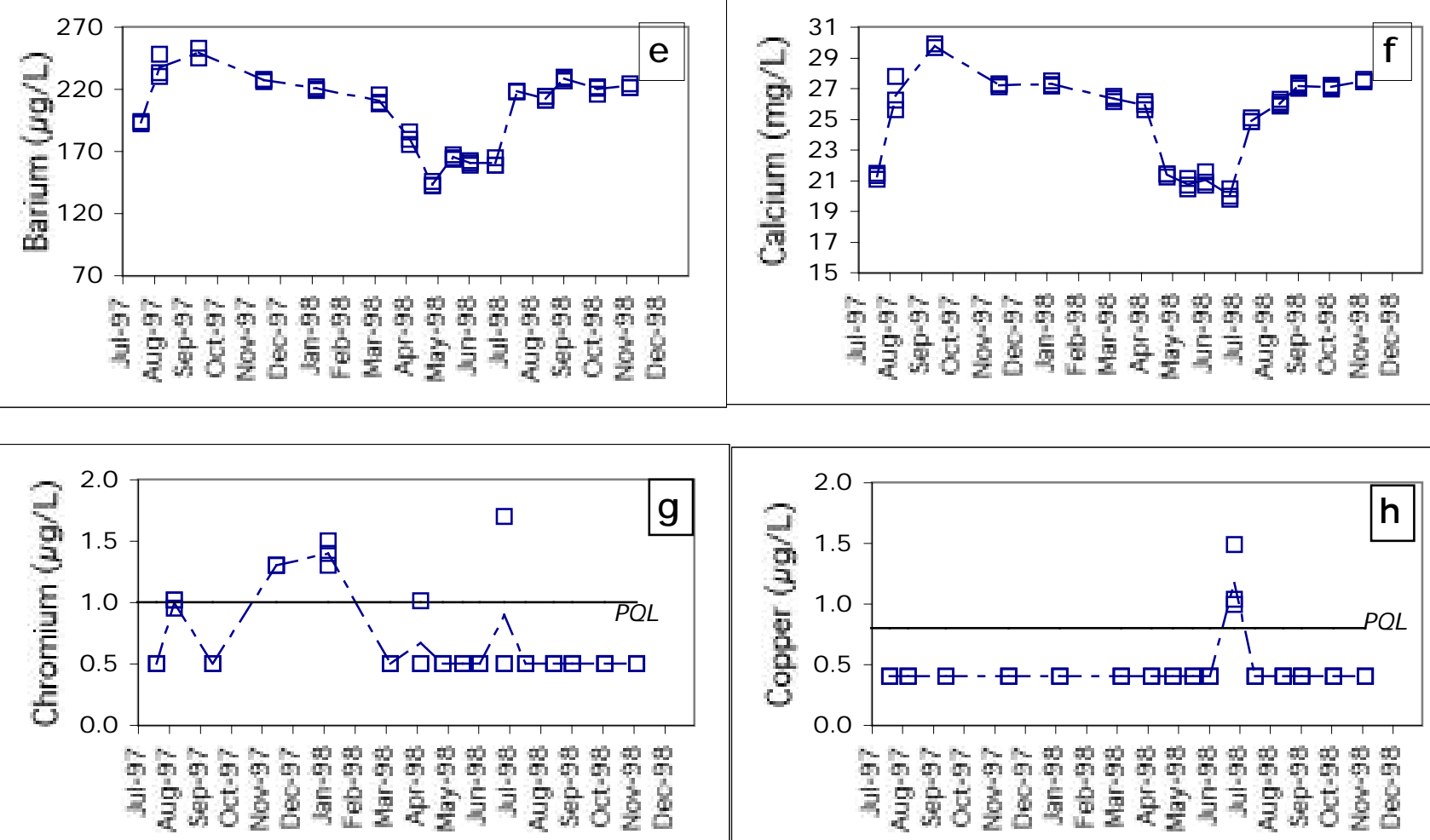
Figures 27i-27p: Trends over time at Blackfoot River site "BC"
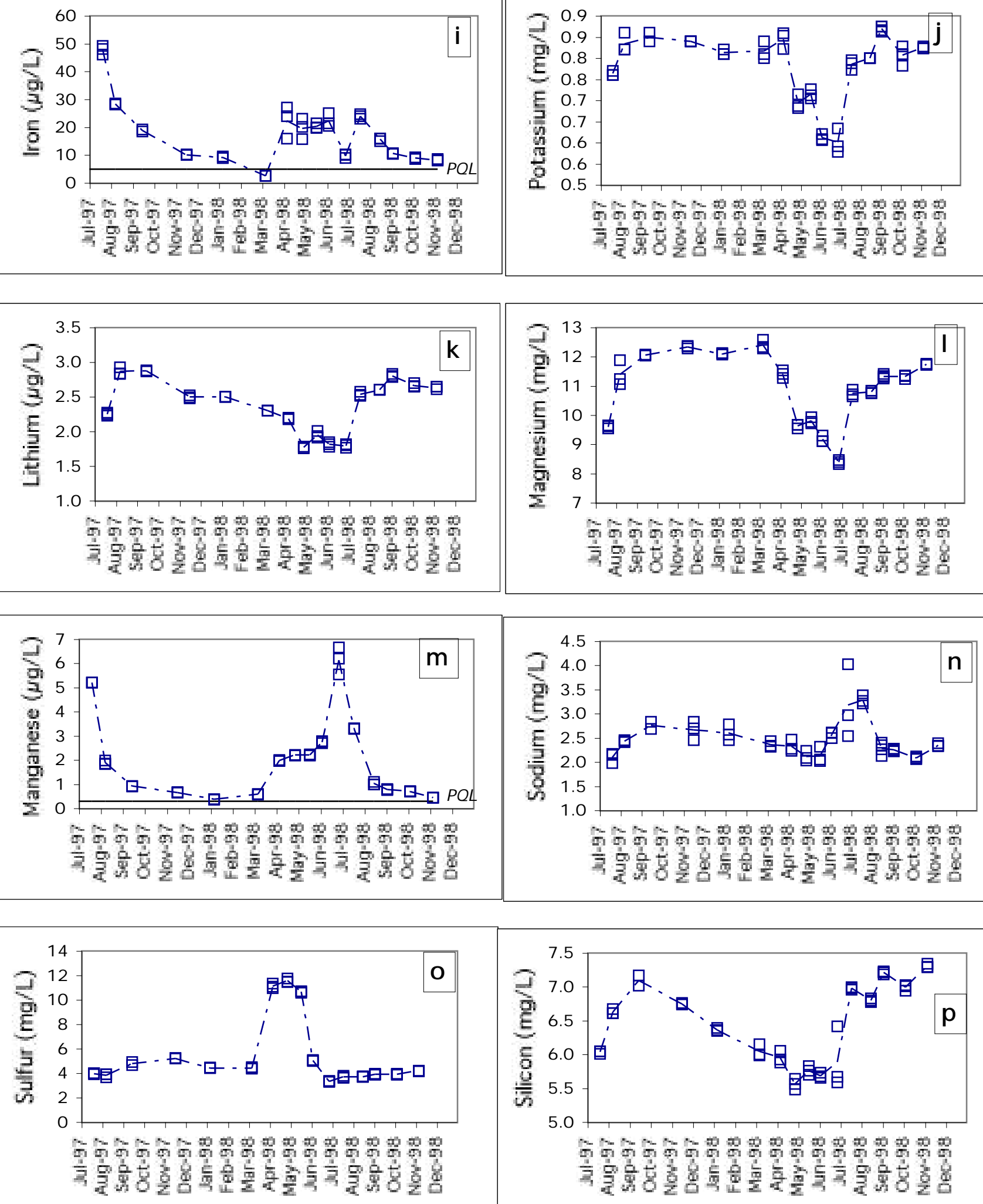
Figures 27q-27r: Trends over time at Blackfoot River site "BC"
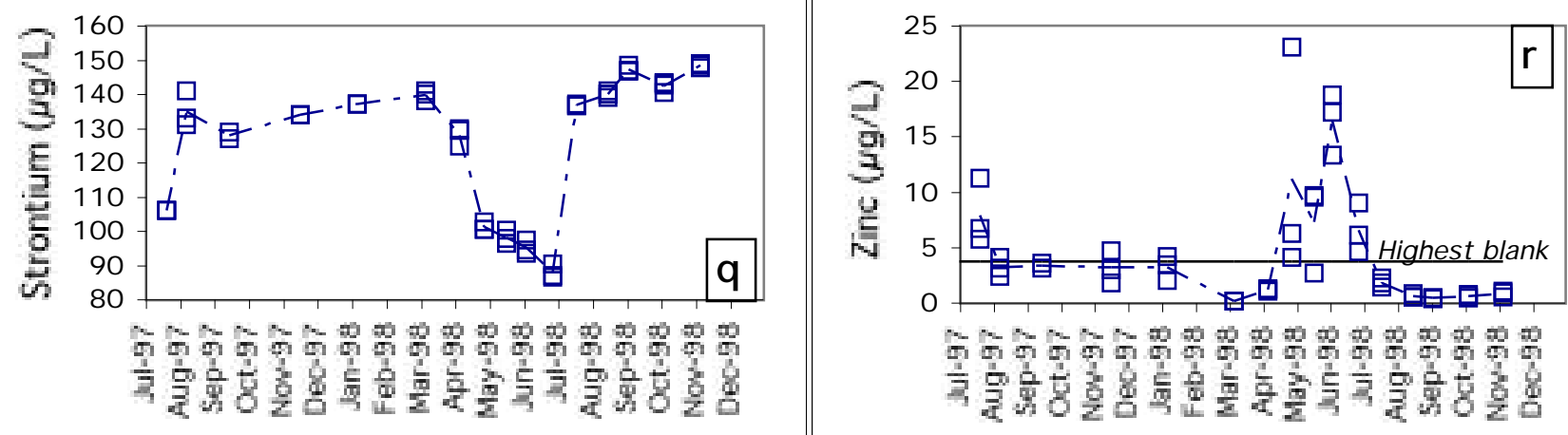

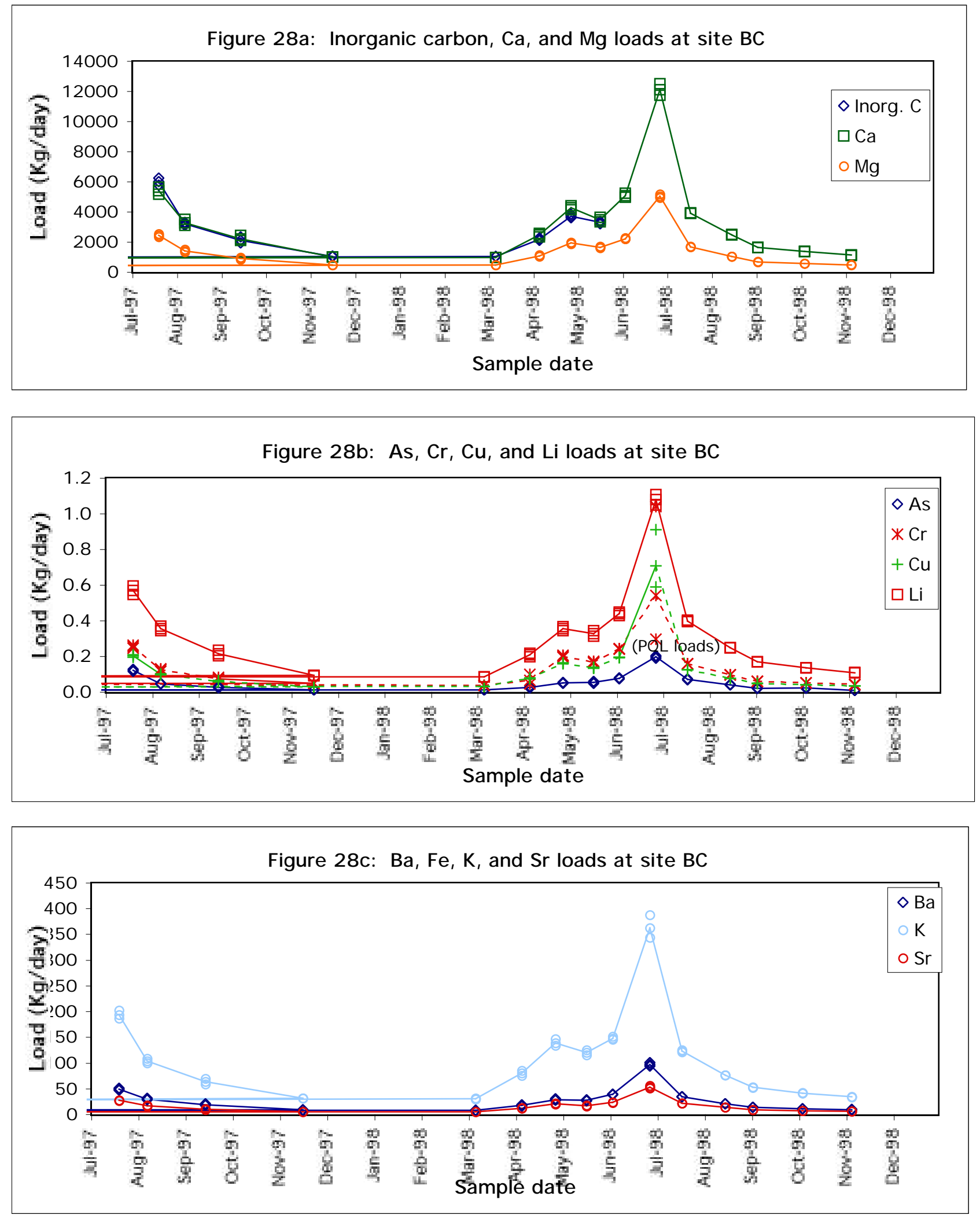
Figure 28d: Fe, Mn, and Zn loads at site BC

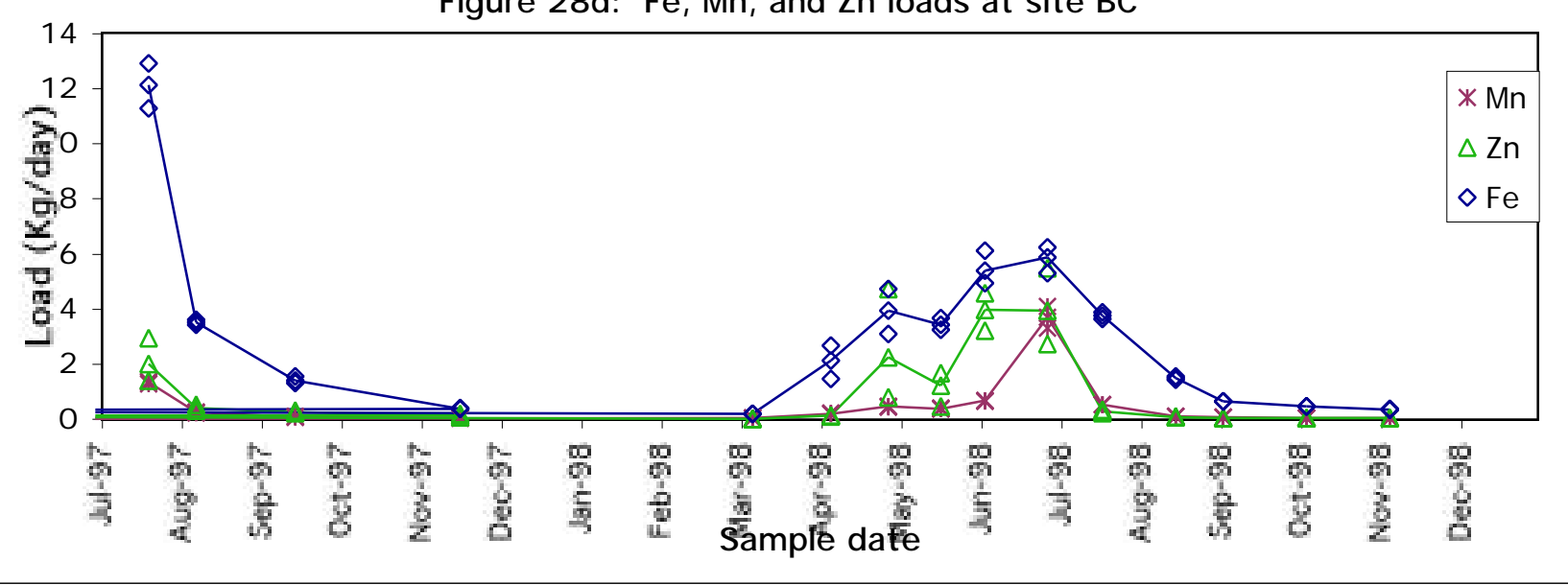

Figure 28e: $\mathrm{Na}, \mathrm{S}$, and $\mathrm{Si}$ loads at site BC

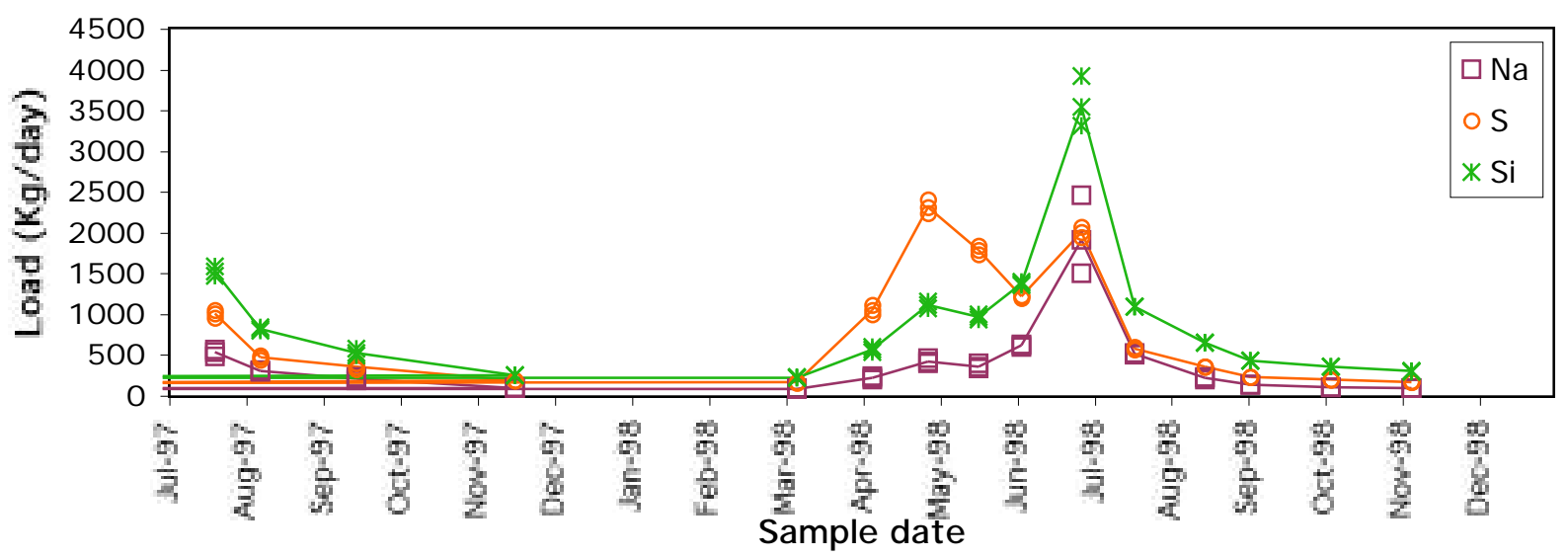

